UNIVERSIDADE DE SÃO PAULO

FACULDADE DE EDUCAÇÃO

PROGRAMA DE PÓS-GRADUAÇÃO EM EDUCAÇÃO

CAMILA YURI SANTANA IKUTA

A QUALIDADE NO PROGRAMA UNIVERSIDADE PARA TODOS (PROUNI) SEGUNDO OS RESULTADOS DE AVALIAÇÃO DE CURSOS DO SISTEMA NACIONAL DE AVALIAÇÃO DA EDUCAÇÃO SUPERIOR (SINAES). 


\title{
A QUALIDADE NO PROGRAMA UNIVERSIDADE PARA TODOS (PROUNI) SEGUNDO OS RESULTADOS DE AVALIAÇÃO DE CURSOS DO SISTEMA NACIONAL DE AVALIAÇÃO DA EDUCAÇÃO SUPERIOR (SINAES).
}

\author{
(versão corrigida)
}

Dissertação apresentada ao Programa de PósGraduação em Educação da Faculdade de Educação da Universidade de São Paulo como parte dos requisitos para a obtenção do título de Mestre em Educação.

Área de concentração: Estado, Sociedade e Educação.

Orientadora: Prof. ${ }^{\mathrm{a}}$ Dr $^{\mathrm{a}}$. Gladys Beatriz Barreyro. 
AUTORIZO A REPRODUÇÃO E DIVULGAÇÃO TOTAL OU PARCIAL DESTE TRABALHO, POR QUALQUER MEIO CONVENCIONAL OU ELETRÔNICO, PARA FINS DE ESTUDO E PESQUISA, DESDE QUE CITADA AFONTE.

Catalogação na Publicação

Serviço de Biblioteca e Documentação

Faculdade de Educação da Universidade de São Paulo

378 Ikuta, Camila Yuri Santana

I26q A qualidade no Programa Universidade para Todos (PROUNI) segundo os resultados de avaliação de cursos do Sistema Nacional de Avaliação da Educação Superior (SINAES) / Camila Yuri Santana Ikuta; orientador Gladys Beatriz Barreyro. São Paulo: s.n., 2016.

226 p.; il.; graf.; tab.; anexos

Dissertação (Mestrado - Programa de Pós-Graduação em Educação. Área de Concentração: Estado, Sociedade e Educação) - - Faculdade de Educação da Universidade de São Paulo.

1. Ensino Superior 2. Qualidade da Educação 3. Avaliação Educacional I. Barreyro, Gladys Beatriz, orient. 


\section{A QUALIDADE NO PROGRAMA UNIVERSIDADE PARA TODOS (PROUNI) SEGUNDO OS RESULTADOS DE AVALIAÇÃO DE CURSOS DO SISTEMA NACIONAL DE AVALIAÇÃO DA EDUCAÇÃO SUPERIOR (SINAES).}

Dissertação apresentada ao Programa de PósGraduação em Educação da Faculdade de Educação da Universidade de São Paulo como parte dos requisitos para a obtenção do título de Mestre em Educação.

Área de concentração: Estado, Sociedade e Educação.

Aprovada em: 24 de maio de 2016

Banca examinadora

Prof $^{a}$. Dr ${ }^{\mathrm{a}}$. Gladys Beatriz Barreyro

Instituição: USP/FE/EACH

Julgamento:

Assinatura:

Prof. Dr. José Vieira de Sousa

Instituição: UnB/FE

Julgamento:

Assinatura:

Prof. Dr. Ocimar Munhoz Alavarse

Instituição: USP/FE

Julgamento:

Assinatura:

Prof. Dr. Romualdo Luiz Portela de Oliveira (suplente)

Instituição: USP/FE

Julgamento:

Assinatura:

Prof $^{\mathrm{a}}$. Dr ${ }^{\mathrm{a}}$. Claudia Maffini Griboski (suplente)

Instituição: UnB/FE

Julgamento:

Assinatura:

Prof $^{a}$. Dra ${ }^{\mathrm{a}}$. Sandra Maria Zakia Lian Sousa (suplente)

Instituição: USP/FE

Julgamento:

Assinatura: 


\section{AGRADECIMENTOS}

À Prof ${ }^{a}$. Dr ${ }^{a}$. Gladys Beatriz Barreyro, por me aceitar no Programa de Pós-Graduação e me proporcionar a oportunidade de estudar nesta universidade, que era um sonho antigo meu. Por acolher minhas ideias e por ter realizado orientações, leituras e apontamentos muito precisos, além de incentivar minha autonomia como pesquisadora.

Aos professores da banca de qualificação, Dr. Afrânio Mendes Catani e Dr. José Vieira de Sousa, pelas leituras cuidadosas e observações extremamente pertinentes, as quais procurei incorporar na dissertação.

Aos(Às) professores(as) Dr. Ocimar Munhoz Alavarse, Dr. Romualdo Luiz Portela de Oliveira, Dr ${ }^{\mathrm{a}}$. Claudia Maffini Griboski e Dr ${ }^{\mathrm{a}}$. Sandra Maria Zakia Lian Sousa, e novamente ao Dr. José Vieira de Sousa, por aceitarem o convite para participar da banca examinadora da defesa.

Aos membros do Subprojeto 3 (Avaliação) da pesquisa sobre Políticas de Expansão da Educação Superior, no âmbito da Rede Universitas/Br, pela participação nas reuniões de trabalho, cujo conteúdo me inspirou a desenvolver muitas questões para a minha pesquisa.

Aos colegas de orientação da pós-graduação Flávio, Emanuel e Gabriella, pelas leituras e comentários sobre o projeto de mestrado e os textos iniciais desta dissertação.

À Flávia Lima, especialmente, por todas as conversas, leituras e discussões compartilhadas nesses mais de três anos de mestrado. Por ter sido uma pessoa, acima de tudo, muito amiga, disposta a contribuir com as suas experiências e a me auxiliar em tantos momentos.

Ao Departamento Intersindical de Estatística e Estudos Socioeconômicos (DIEESE), cujo trabalho desenvolvido foi fundamental para o meu amadurecimento em relação à pesquisa, com o qual pude realizar o mestrado de forma menos insegura. Aos companheiros de DIEESE que, direta ou indiretamente, contribuíram para que essa dissertação pudesse ser realizada: Airton Santos, por todas as oportunidades profissionais que me proporcionou, e também pelas inúmeras flexibilizações da jornada de trabalho - especialmente na época mais complicada, em que realizei disciplinas no período da tarde. Altair Garcia, pelo incentivo e contribuições ao projeto de mestrado, assim como também pelo auxílio em relação à jornada de trabalho. Aos 
companheiros dos tempos de subseção, que tanto animaram meus almoços com conversas, observações, conselhos: Ricardo Tamashiro e Daniel Ferrer. Ao Ilmar Silva, por ter me salvado com algumas fórmulas de Excel. Aos colegas da Biblioteca da Escola DIEESE de Ciências do Trabalho, que sempre me receberam muito bem nas tantas noites que utilizei esse espaço para escrever.

À Thamires Silva, por todo o companheirismo e amizade nesses muitos anos, desde os nossos tempos de estágio. Por todos os momentos que trocamos experiências de trabalho, do mestrado, de vida. Pelas contribuições, passeios, cafés e bares, compartilhando tantas alegrias e angústias, o que certamente me ajudou a continuar realizando esta pesquisa.

À minha orientadora de Trabalho de Conclusão de Curso da PUC-SP, Prof ${ }^{a}$. Dr ${ }^{\mathrm{a}}$. Matilde Melo, por ter auxiliado na construção do meu projeto inicial de mestrado, mesmo quando não era mais sua obrigação fazê-lo. Foi um passo fundamental para o meu ingresso no Programa de PósGraduação.

Ao Rogério Limonti, por ter se disposto, gentilmente, a me colocar em contato com a Prof ${ }^{a}$. Gladys.

Ao Vitor Vaneti e à Fabiane Lima, por terem avaliado minha base de dados em relação à metodologia de pesquisa.

Ao Thiago, pelo amor e companheirismo durante todo esse tempo, o que foi muito importante para seguir em frente. Pelo incentivo e pela paciência em ouvir diariamente tantos desdobramentos dos altos e baixos que envolvem construir um trabalho desse tipo, cuja jornada você acompanhou praticamente desde o início.

Ao Programa Universidade para Todos (ProUni), pois apesar de todas as contradições envolvidas, foi por meio desta política que consegui ingressar em uma universidade bem conceituada, a qual não teria chances de pagar pelas altas mensalidades. Por abrir as portas para a oportunidade de entrar em contato com o mundo da pesquisa acadêmica e assim, problematizar minha própria condição de beneficiária.

Por fim, agradeço aos meus pais, Marlene e Seiji, por quem sou hoje. 
"Os deuses descansam e divertem-se!

Os sujeitos são os homens e a tarefa da história... é estabelecer a verdade deste mundo." 


\section{RESUMO}

IKUTA, C. Y. S. A qualidade no Programa Universidade para Todos (ProUni) segundo os resultados de avaliação de cursos do Sistema Nacional de Avaliação da Educação Superior (SINAES). 2016. 226p. Dissertação (Mestrado em Educação) - Faculdade de Educação, Universidade de São Paulo, São Paulo, 2016.

A presente pesquisa teve como objetivo discutir a questão da qualidade dos cursos que ofertam bolsas no Programa Universidade para Todos (ProUni). O ProUni é uma política educacional desencadeada pelo Governo Federal e implementada em 2005. É voltada ao segmento de educação superior, possuindo como uma de suas premissas a democratização do acesso, realizando a concessão de bolsas de estudos para estudantes de cursos de graduação e sequenciais de formação específica em Instituições de Ensino Superior (IES) privadas em todo o país. O referencial teórico foi construído em torno da revisão bibliográfica de quatro temas: a trajetória da educação superior brasileira; as políticas de avaliação, em especial o Sistema Nacional de Avaliação da Educação Superior (SINAES); a discussão conceitual sobre qualidade da educação superior; e o debate em torno da política do Programa Universidade para Todos. No desenvolvimento da pesquisa foram utilizados procedimentos metodológicos quantitativos, por meio da análise de dados sobre os cursos que ofertaram bolsas pelo ProUni no município de São Paulo-SP, no primeiro semestre de 2014, em relação aos resultados do Conceito Preliminar de Curso (CPC), considerado o indicador oficial de avaliação da qualidade dos cursos superiores brasileiros. Foi constatado nos resultados que, no caso do grupo de cursos ProUni selecionado, nem sempre apresentam-se resultados ligados à baixa qualidade (considerando como referência de qualidade o CPC). Verificou-se que há concentração predominante na faixa 3 do indicador, considerada satisfatória; entretanto, há menos cursos na faixa 4 e um número bastante reduzido na faixa 5 , que são consideradas como as que possuem maior relação com os critérios de qualidade exigidos. Também, há uma parcela menor de cursos com ausência de conceito ou de reconhecimento, o que pode trazer incertezas sobre a qualidade ofertada. Além disso, a correspondência com os critérios de qualidade utilizados mostrou-se desigual quando foram consideradas variáveis como o grau acadêmico (bacharelados e tecnólogos), o tipo de bolsa ofertada (integral ou parcial) e a área de enquadramento dos cursos. Ao realizar uma comparação entre o grupo de cursos ProUni selecionado, em relação com os demais cursos avaliados pelo CPC, em São Paulo-SP e no Brasil, observou-se que os cursos ProUni acompanharam a tendência de resultados dos demais cursos, e em alguns casos, apresentaram inclusive resultados melhores em relação às faixas do CPC. Diante desse quadro, finaliza-se com uma discussão em torno dos limites e possibilidades da avaliação da qualidade dos cursos no ProUni, considerando a literatura sobre esses temas.

Palavras-chave: Programa Universidade para Todos. Educação Superior. Avaliação. SINAES. Conceito Preliminar de Curso. 


\begin{abstract}
IKUTA, C. Y. S. Quality in the Program University for All (ProUni) according to the course assessment results by the National Higher Education Assessment System (SINAES). 2016. 226p. Thesis (M.A in Education) - School of Education, University of São Paulo, São Paulo, 2016.
\end{abstract}

The objective of this study was the quality of the courses that offer scholarships through the Program University for All (ProUni). ProUni is an educational policy unleashed by the Federal Government and implemented in 2005. It is intended for higher education with the assumption of democratizing the access by granting scholarships to undergraduates for further specific training in private Higher Education Institutions (IES) all over Brazil. The theoretical framework includes the bibliographical review regarding four topics: the trajectory of higher education in Brazil; the assessment policies, especially the National Higher Education Assessment System (SINAES); the conceptual discussion of quality in higher education; and the debate around the policy of the Program University for All. The methodological procedures of this research were quantitative and analyzed data about the degrees that provide scholarships through ProUni in the city of São Paulo-SP, along the first semester of 2014, in relation to the results of the Preliminary Course Grade (CPC), considering the official indicator of the quality assessment for the Brazilian higher education degrees. The results have shown that, in the case of the ProUni courses selected, not always results were associated with low quality (taking CPC as quality reference). There was a predominant concentration on level 3 of the indicator, considered satisfactory; however, there are less degree courses on level 4 and a rather reduced number on level 5, which are defined as the levels with more compliance with the required quality criteria. Also, there is smaller group of degrees with no grade assigned or officially recognized by the educational authority, which may bring uncertainties about the quality provided by such courses. In addition, the correspondence with the quality criteria utilized turned out to be unequal when considering variables such as the academic level (professional or technical degree), the type of scholarship offered (full or partial) and the framing area of the courses. By comparing the group of ProUni degrees selected, in relation to other degrees assessed by CPC, in São Paulo-SP and in Brazil, it was found that ProUni courses went along the trend of other courses in terms of assessment results, and in some cases, they had better results regarding the CPC levels. Faced with this situation, there is a final discussion around the limits and possibilities of quality assessment for ProUni degree courses, taking the literature covering these topics into consideration.

Key words: Program University for All. Higher Education. Assessment. SINAES. Preliminary Course Grade. 


\section{LISTA DE ILUSTRAÇÕES}

\section{Lista de Figuras}

Figura 1 - Equação de cálculo do Conceito Preliminar de Curso 2012. 145

\section{Lista de Quadros}

Quadro 1 - Visões de Qualidade da Educação Superior 82

Quadro 2 - Principais aspectos e mudanças do cálculo do Conceito Preliminar de Curso (CPC) no período de 2007 a 2013

\section{Lista de Gráficos}

Gráfico 1 - Número de Instituições de Ensino Superior e variação anual (em \%), por categoria administrativa (pública e privada) - Brasil, 1990-2000.... 38

Gráfico 2 - Número de Instituições de Ensino Superior e variação anual (em \%), por categoria administrativa (pública e privada) - Brasil, 2000-2013

Gráfico 3 - Taxas de matrícula bruta e líquida na educação superior (em \%). Brasil, 2003 a 2013.

Gráfico 4 - Estimativa do Investimento Público Total e Investimento Público Direto em Educação, em relação ao Produto Interno Bruto (PIB), por nível de ensino (em $\%)$. Brasil, 2000 a 2013. 54

Gráfico 5 - Estimativa de renúncia fiscal das entidades privadas que aderiram ao ProUni. Brasil, 2005 a 2016

Gráfico 6 - Número de bolsas do ProUni ofertadas por ano. Brasil, 2005-2014 ............. 116

Gráfico 7 - Número de bolsistas ProUni por sexo. Brasil, 2005-2014 ............................. 118

Gráfico 8 - Número de bolsistas ProUni por raça/cor. Brasil, 2005-2014 ...................... 118

Gráfico 9 - Número de bolsistas ProUni por modalidade de ensino. Brasil, 2005-2014 . 119

Gráfico 10 - Número de bolsistas ProUni por turno (cursos presenciais). Brasil, 2005-2014

Gráfico 11 - Bolsistas ProUni por categoria administrativa da Instituição de Ensino Superior (em \%). Brasil, 2005-2014.

Gráfico 12 - Número de bolsistas ProUni por grandes regiões brasileiras. Brasil, 2005-2014

Gráfico 13 - Principais municípios do estado de São Paulo com maior número de bolsas ProUni ofertadas no processo seletivo 2/2013 (em \%). 
Gráfico 14 - Principais municípios do estado de São Paulo com maior número de bolsas ProUni ofertadas no processo seletivo 1/2014 (em \%)

Gráfico 15 - Principais cursos com maior oferta de bolsas ProUni no processo seletivo 2/2013 (em \%) - Município de São Paulo-SP

Gráfico 16 - Principais cursos com maior oferta de bolsas ProUni no processo seletivo 1/2014 (em \%) - Município de São Paulo-SP

Gráfico 17 - Distribuição dos cursos que ofereceram bolsas no processo seletivo do ProUni 1/2014 no município de São Paulo-SP, em relação aos demais cursos do município e do Brasil, segundo resultados do Conceito Preliminar de Curso (CPC) 2012

Gráfico 18 - Distribuição dos cursos de Administração que ofereceram bolsas no processo seletivo do ProUni 1/2014, no município de São Paulo-SP, em relação aos demais cursos do município e do Brasil, segundo resultados do Conceito Preliminar de Curso (CPC) 2012 170

Gráfico 19 - Distribuição dos cursos de Ciências Contábeis que ofereceram bolsas no processo seletivo do ProUni 1/2014, no município de São Paulo-SP, em relação aos demais cursos do município e do Brasil, segundo resultados do Conceito Preliminar de Curso (CPC) 2012 171

Gráfico 20 - Distribuição dos cursos de Tecnologia em Gestão de Recursos Humanos que ofereceram bolsas no processo seletivo do ProUni 1/2014, no município de São Paulo-SP, em relação aos demais cursos do município e do Brasil, segundo resultados do Conceito Preliminar de Curso (CPC) 2012

Gráfico 21 - Distribuição dos cursos de Tecnologia em Logística que ofereceram bolsas no processo seletivo do ProUni 1/2014, no município de São Paulo-SP, em relação aos demais cursos do município e do Brasil, segundo resultados do Conceito Preliminar de Curso (CPC) 2012 172

Gráfico 22 - Distribuição dos cursos de Direito que ofereceram bolsas no processo seletivo do ProUni 1/2014, no município de São Paulo-SP, em relação aos demais cursos do município e do Brasil, segundo resultados do Conceito Preliminar de Curso (CPC) 2012 173

Gráfico 23 - Distribuição dos cursos que ofereceram bolsas no processo seletivo do ProUni 1/2014, no município de São Paulo-SP, em relação aos demais cursos do 
município e do Brasil, por Organização Acadêmica da Instituição ofertante, segundo resultados do Conceito Preliminar de Curso 2012

Gráfico 24 - Distribuição dos cursos que ofereceram bolsas no processo seletivo do ProUni 1/2014, no município de São Paulo-SP, em relação aos demais cursos do município e do Brasil, segundo resultados do Conceito Preliminar de Curso 2012 no componente Docentes com Mestrado

Gráfico 25 - Distribuição dos cursos que ofereceram bolsas no processo seletivo do ProUni 1/2014, no município de São Paulo-SP, em relação aos demais cursos do município e do Brasil, segundo resultados do Conceito Preliminar de Curso 2012 no componente Docentes com Doutorado

Gráfico 26 - Distribuição dos cursos que ofereceram bolsas no processo seletivo do ProUni 1/2014 no município de São Paulo-SP, em relação aos demais cursos do município e do Brasil, segundo resultados do Conceito Preliminar de Curso 2012 no componente Regime de trabalho (integral/parcial).

Gráfico 27 - Distribuição dos cursos que ofereceram bolsas no processo seletivo do ProUni 1/2014, no município de São Paulo-SP, em relação aos demais cursos do município e do Brasil, segundo resultados do Conceito Preliminar de Curso 2012 no componente Formação Geral

Gráfico 28 - Distribuição dos cursos que ofereceram bolsas no processo seletivo do ProUni 1/2014, no município de São Paulo-SP, em relação aos demais cursos do município e do Brasil, segundo resultados do Conceito Preliminar de Curso 2012 no quesito Componente Específico 182

Gráfico 29 - Distribuição dos cursos que ofereceram bolsas no processo seletivo do ProUni 1/2014, no município de São Paulo-SP, em relação aos demais cursos do município e do Brasil, segundo resultados do Conceito Preliminar de Curso 2012 no componente Indicador de Diferença entre os Desempenhos Observado e Esperado.

Gráfico 30 - Distribuição dos cursos que ofereceram bolsas no processo seletivo do ProUni 1/2014, no município de São Paulo-SP, em relação aos demais cursos do município e do Brasil, segundo resultados do Conceito Preliminar de Curso 2012 no componente Infraestrutura

Gráfico 31 - Distribuição dos cursos que ofereceram bolsas no processo seletivo do ProUni 1/2014, no município de São Paulo-SP, em relação aos demais cursos do 
município e do Brasil, segundo resultados do Conceito Preliminar de Curso 2012 no componente Organização Didático-Pedagógica .................................... 185 


\section{LISTA DE TABELAS}

Tabela 1 - Número de contratos formalizados do Fundo de Financiamento Estudantil (Fies). Brasil, 1999-2014

Tabela 2 - Número de matrículas, segundo a categoria administrativa da IES. Brasil, 20002013.

Tabela 3 - Funções docentes em exercício na educação superior, por categoria administrativa da IES, grau de formação e regime de trabalho. Brasil, 2003 e 2013.

Tabela 4 - N Número de matrículas na educação superior, por modalidade de ensino. Brasil, 2003-2013

Tabela 5 - $\quad$ Número de matrículas em Instituições de Ensino Superior Privadas (Graduação) e número de bolsas ProUni ofertadas. Brasil, 2005 a 2014

Tabela 6 - Alíquotas e base de cálculo dos Tributos Federais por categoria de IES Comparação com e sem ProUni. Brasil, 2011

Tabela 7 - Número de bolsas ofertadas e número de inscritos no ProUni por processo seletivo. Brasil, 2005-2014

Tabela 8 - Número de bolsas ProUni ofertadas nos processos seletivos 2/2013 e 1/2014 Brasil e UFs.

Tabela 9 - $\quad$ Principais Instituições de Ensino Superior que mais ofertaram bolsas do ProUni no processo seletivo 1/2014. Estado de São Paulo, 2014

Tabela 10 - Número de bolsas ProUni ofertadas nos processos seletivos 2/2013 e 1/2014, por tipo de bolsa - Município de São Paulo-SP

Tabela 11 - Número de bolsas ProUni ofertadas no processo seletivo 1/2014, por turno do curso - Município de São Paulo-SP.

Tabela 12 - Principais cursos com maior oferta de bolsas ProUni no processo seletivo 1/2014, por tipo de bolsa - Município de São Paulo-SP.

Tabela 13 - Principais Instituições de Ensino Superior que mais ofertaram bolsas ProUni no processo seletivo 1/2014 - Município de São Paulo-SP

Tabela 14 - Principais Instituições de Ensino Superior que mais ofertaram bolsas ProUni do curso de Administração no processo seletivo 1/2014 - Município de São PauloSP

Tabela 15 - Peso dos Componentes no Conceito Preliminar de Curso 2012 145 
Tabela 16 - Valores contínuos e valores por faixas do Conceito Preliminar de Curso 2012 146

Tabela 17 - Distribuição dos cursos que ofereceram bolsas no processo seletivo do ProUni 1/2014, no município de São Paulo-SP, segundo resultados do Conceito Preliminar de Curso (CPC) 2012 ............................................................... 159

Tabela 18 - Distribuição das bolsas ofertadas pelos cursos selecionados no processo seletivo do ProUni 1/2014, no município de São Paulo-SP, por tipo de bolsa, segundo resultados do Conceito Preliminar de Curso (CPC) 2012

Tabela 19 - Distribuição dos cursos que ofereceram bolsas no processo seletivo do ProUni 1/2014, no município de São Paulo-SP, segundo resultados do Conceito Preliminar de Curso (CPC) 2012, por grau acadêmico. 163

Tabela 20 - Distribuição dos cursos de Bacharelado que ofereceram bolsas no processo seletivo do ProUni 1/2014, no município de São Paulo-SP, segundo resultados do Conceito Preliminar de Curso (CPC) 2012. 165

Tabela 21 - Distribuição dos Cursos Superiores de Tecnologia que ofereceram bolsas no processo seletivo do ProUni 1/2014, no município de São Paulo-SP, segundo resultados do Conceito Preliminar de Curso (CPC) 2012 166

Tabela 22 - Distribuição dos cursos que ofereceram bolsas no processo seletivo do ProUni 1/2014 no município de São Paulo-SP, em relação aos demais cursos do município e do Brasil, segundo resultados do Conceito Preliminar de Curso (CPC) 2012 167

Tabela 23 - Distribuição dos cursos que ofereceram bolsas no processo seletivo do ProUni 1/2014, no município de São Paulo-SP, em relação aos demais cursos do município e do Brasil, por Organização Acadêmica da Instituição ofertante, segundo resultados do Conceito Preliminar de Curso 2012 


\section{LISTA DE ABREVIATURAS E SIGLAS}

ABMES

ANUP

BASis

$\mathrm{BB}$

$\mathrm{BCB}$

BIRD

CAPES

$\mathrm{CC}$

CEA

CEF

CFE

CI

$\mathrm{CNE}$

$\mathrm{CNPq}$

CNRES

COFINS

CONAES

CPA

$\mathrm{CPC}$

CSLL

CST

DAES

$\mathrm{EaD}$

ENADE

ENC

ENEM

E-SIC

ESPM

FACSP

FAPCOM

FATEMA
Associação Brasileira de Mantenedoras de Ensino Superior

Associação Nacional das Universidades Particulares

Banco de Avaliadores do Sistema Nacional de Avaliação da Educação Superior

Banco do Brasil

Banco Central do Brasil

Banco Internacional para Reconstrução e Desenvolvimento

Coordenação de Aperfeiçoamento de Pessoal de Nível Superior

Conceito de Curso

Comissão Especial de Avaliação

Caixa Econômica Federal

Conselho Federal de Educação

Conceito Institucional

Conselho Nacional de Educação

Conselho Nacional de Pesquisa e Desenvolvimento Tecnológico

Comissão Nacional de Reformulação do Ensino Superior

Contribuição Social para o Financiamento da Seguridade Social

Comissão Nacional de Avaliação da Educação Superior

Comissão Própria de Avaliação

Conceito Preliminar de Curso

Contribuição Social sobre o Lucro Líquido

Curso Superior de Tecnologia

Diretoria de Avaliação da Educação Superior

Educação a Distância

Exame Nacional de Desempenho dos Estudantes

Exame Nacional de Cursos

Exame Nacional do Ensino Médio

Sistema Eletrônico de Informação ao Cidadão

Escola Superior de Propaganda e Marketing

Faculdade São Paulo

Faculdade Paulus de Tecnologia e Comunicação

Faculdade de São Paulo 
FCDA

FGEDUC

FGV

FHC

Fies

FMI

FMU

FNDE

FPD

FUVEST

GERES

IBGE

IBOPE

IDD

IDH

IES

IF

IFC

IGC

INEP

INSPER

IPEA

IRPJ

ISES

LDB

MEC

NC

NF

NO

NPD

NPM

NPR

OCDE
Faculdade Carlos Drummond de Andrade

Fundo de Garantia de Operações de Crédito Educativo

Fundação Getúlio Vargas

Fernando Henrique Cardoso

Fundo de Financiamento Estudantil

Fundo Monetário Internacional

Faculdades Metropolitanas Unidas

Fundo Nacional de Desenvolvimento da Educação

Faculdade Paschoal Dantas

Fundação Universitária para o Vestibular

Grupo Executivo para a Reformulação do Ensino Superior

Instituto Brasileiro de Geografia e Estatística

Instituto Brasileiro de Opinião Pública e Estatística

Indicador de Diferença entre os Desempenhos Observado e Esperado

Índice de Desenvolvimento Humano

Instituições de Ensino Superior

Instituto Federal de Educação, Ciência e Tecnologia

Internacional Finance Corporation

Índice Geral de Cursos

Instituto Nacional de Pesquisas Educacionais Anísio Teixeira

Instituto de Ensino e Pesquisa

Instituto de Pesquisa Econômica Aplicada

Imposto de Renda das Pessoas Jurídicas

Faculdade Sumaré

Lei de Diretrizes e Bases da Educação Nacional

Ministério da Educação

Nota dos Concluintes

Nota de Infraestrutura

Nota de Organização Didático-Pedagógica

Nota de Professores Doutores

Nota de Professores Mestres

Nota sobre Regime de Trabalho parcial/integral

Organização para a Cooperação e Desenvolvimento Econômico 
PAIUB

Paru

PCB

PCdoB

PCE/CREDUC

PIB

PIS

PL

PMN

PNAD

PNE

PNUD

PPP

ProUni

PT

PUC-CAMPINAS

PUC-SP

Reuni

SC

Semesp

SENACSP

SERES

SESu

SINAES

SIPS

SisProuni

TCC

TCU

$\mathrm{UAB}$

UAM

UNE

Unesco
Programa de Avaliação Institucional da Universidade Brasileira

Programa de Avaliação da Reforma Universitária

Partido Comunista Brasileiro

Partido Comunista do Brasil

Programa de Crédito Educativo

Produto Interno Bruto

Programa de Integração Social

Partido Liberal

Partido da Mobilização Nacional

Pesquisa Nacional por Amostra de Domicílios

Plano Nacional de Educação

Programa das Nações Unidas para o Desenvolvimento

Parceria Público-Privada

Programa Universidade para Todos

Partido dos Trabalhadores

Pontifícia Universidade Católica de Campinas

Pontifícia Universidade Católica de São Paulo

Programa de Apoio aos Planos de Reestruturação e Expansão das Universidades Federais

Sem Conceito

Sindicato das Entidades Mantenedoras de Estabelecimentos de Ensino Superior do Estado de São Paulo

Centro Universitário Senac

Secretaria de Regulação da Educação Superior

Secretaria de Educação Superior

Sistema Nacional de Avaliação da Educação Superior

Sistema de Indicadores de Percepção Social

Sistema Informatizado do ProUni

Trabalho de Conclusão de Curso

Tribunal de Contas da União

Universidade Aberta do Brasil

Universidade Anhembi Morumbi

União Nacional dos Estudantes

Organização das Nações Unidas para a Educação, a Ciência e a Cultura 


$\begin{array}{ll}\text { UNIARARAS } & \text { Centro Universitário Herminio Ometto } \\ \text { UNIB } & \text { Universidade Ibirapuera } \\ \text { UNICSUL } & \text { Universidade Cruzeiro do Sul } \\ \text { UNINOVE } & \text { Universidade Nove de Julho } \\ \text { UNIP } & \text { Universidade Paulista } \\ \text { UNISA } & \text { Universidade de Santo Amaro } \\ \text { UNOESTE } & \text { Universidade do Oeste Paulista } \\ \text { UNOPAR } & \text { Universidade Norte do Paraná } \\ \text { USC } & \text { Universidade do Sagrado Coração } \\ \text { USTJ } & \text { Universidade São Judas Tadeu }\end{array}$




\section{SUMÁRIO}

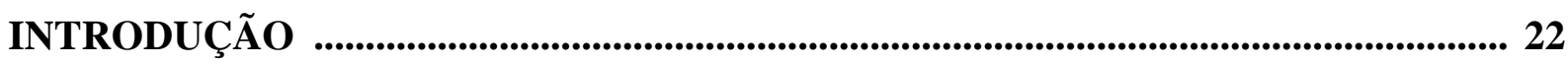

CAPÍTULO 1 - EDUCAÇÃO SUPERIOR, AVALIAÇÃO E QUALIDADE ................. 29

1.1 Histórico da Educação Superior brasileira: principais acontecimentos............................ 29

1.1.2 Da criação da primeira universidade (1920) à Reforma Universitária de 1968 ............. 29

1.1.3 Reformas educacionais a partir da década de 1990: movimentos de expansão e

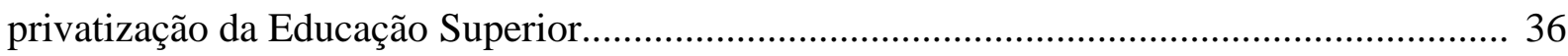

1.1.4 Políticas educacionais de nível superior a partir de 2003: democratização do acesso e expansão do setor público federal ................................................................................ 41

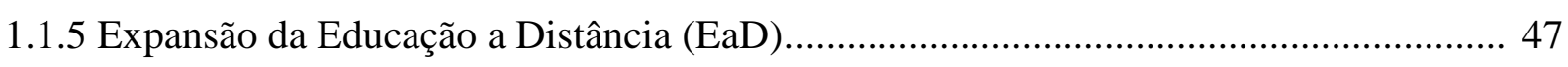

1.1.6 Os movimentos de financeirização, oligopolização e internacionalização da Educação

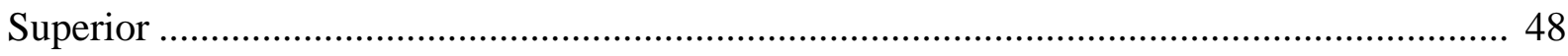

1.1.7 Desafios da democratização do acesso à educação superior ........................................ 51

1.2. Histórico da Avaliação da Educação Superior no Brasil................................................ 57

1.3. O Sistema Nacional de Avaliação da Educação Superior (SINAES) ............................. 63

1.3.1. O Exame Nacional de Desempenho dos Estudantes (ENADE) .................................. 65

1.3.1.1. Principais mudanças metodológicas do ENADE ................................................. 68

1.3.2. O Conceito Preliminar de Curso (CPC) e o Índice Geral de Cursos (IGC) .................. 71

1.4. Qualidade e Avaliação da Educação Superior .................................................................. 77

1.4.1 Qualidade da Educação Superior: concepções e importância ....................................... 78

1.4.2 O debate sobre Qualidade e Avaliação da Educação Superior no Brasil: limites e

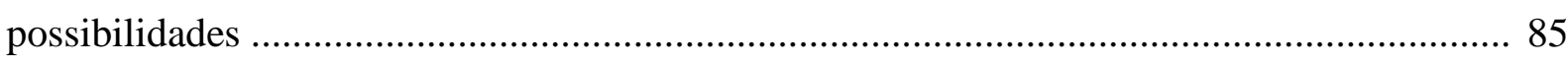

CAPÍTULO 2 - O PROGRAMA UNIVERSIDADE PARA TODOS (PROUNI) ........... 93

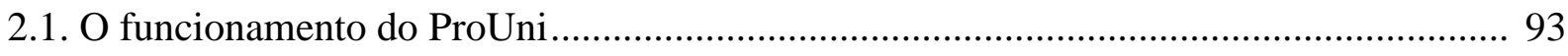

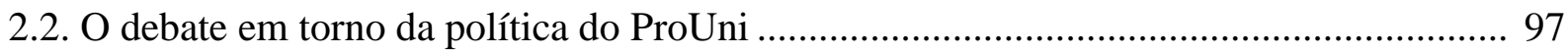

2.3. O ProUni: bolsas ofertadas e perfil dos bolsistas (2005-2014) ................................... 115

2.4. O ProUni: processos seletivos de 2013 e 2014 ................................................................ 123

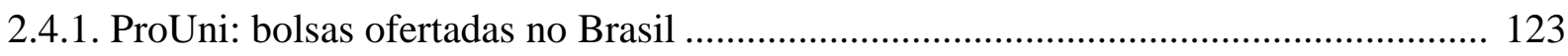

2.4.2. ProUni: bolsas ofertadas no estado de São Paulo ..................................................... 125

2.4.3. ProUni: bolsas ofertadas no município de São Paulo-SP ......................................... 128 


\section{CAPÍTULO 3 - A QUALIDADE NO PROGRAMA UNIVERSIDADE PARA TODOS (PROUNI) SEGUNDO OS RESULTADOS DE AVALIAÇÃO DO CONCEITO PRELIMINAR DE CURSO (CPC) .............................................................................. 137}

3.1 A Avaliação de cursos no SINAES: o Conceito Preliminar de Curso (CPC) ................. 137

3.2. O ProUni e os resultados de Avaliação de cursos ........................................................ 153

3.3. O ProUni e os resultados do Conceito Preliminar de Curso (CPC) 2012 ..................... 156

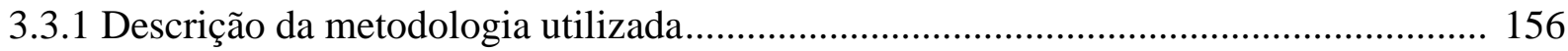

3.3.2 Cursos que ofereceram bolsas no processo seletivo do ProUni 1/2014, segundo as faixas de resultados do Conceito Preliminar de Curso (CPC) 2012 ............................................. 159

3.3.2.1 Comparações Regionais: cursos ProUni e demais cursos de São Paulo-SP e Brasil..167

3.3.3 Cursos que ofereceram bolsas no processo seletivo do ProUni 1/2014, segundo os resultados dos componentes do Conceito Preliminar de Curso (CPC) 2012 ........................ 175

CONSIDERAÇÕES FINAIS ............................................................................................. 186

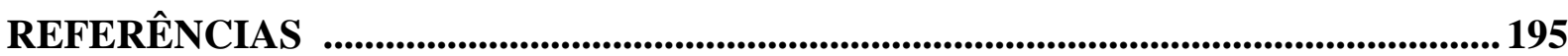

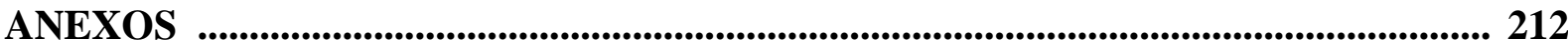

Anexo A - Áreas e cursos de graduação avaliados pelo ENADE (2004-2014)................... 213

Anexo B - Questionários do Estudante do ENADE de 2012 e 2013 .................................... 215

Anexo C - Nota Técnica sobre o cálculo do Indicador de Diferença entre os Desempenhos

Observado e Esperado (IDD) 2012 


\section{INTRODUÇÃO}

A presente pesquisa investigou a questão da qualidade dos cursos que ofertam bolsas no Programa Universidade para Todos (ProUni), política educacional desencadeada pelo Governo Federal, criada em 2004 e implementada pela Lei no 11.096/2005. É uma política voltada ao segmento de educação superior, possuindo como uma de suas premissas a democratização do acesso, por meio da concessão de bolsas de estudos para estudantes de cursos de graduação e sequenciais de formação específica em Instituições de Ensino Superior (IES) privadas (com ou sem fins lucrativos) em todo o território nacional.

O interesse pelo tema do ProUni possui forte relação com a minha trajetória acadêmica, principalmente em seu início. Em 2007, participei de um processo seletivo do ProUni e fui contemplada com uma bolsa integral para o curso de graduação em Ciências Sociais na Pontifícia Universidade Católica de São Paulo (PUC-SP). A oportunidade conquistada por meio do ProUni, face ao insucesso nos vestibulares de instituições públicas que prestara anteriormente, e a convivência com diversos outros bolsistas que passaram pelo mesmo processo e possuíam trajetórias de vida semelhantes às minhas (em contraste com os demais alunos não bolsistas), por si só, já haviam me rendido inúmeras reflexões e questionamentos sobre o Programa. Devido ao interesse crescente relativo ao tema, ainda durante a graduação participei de um grupo de pesquisa enquanto bolsista de Iniciação Científica, financiada pelo Conselho Nacional de Pesquisa e Desenvolvimento Tecnológico (CNPq) e finalizei um Trabalho de Conclusão de Curso (TCC), ambos sobre o tema do ProUni.

No processo de construção desta dissertação de mestrado, foram realizados diversos levantamentos da literatura relacionada ao ProUni em busca de lacunas, ou seja: aspectos que ainda não tinham sido investigados. A revisão bibliográfica apoiou-se em autores como Carvalho (2006, 2011a, 2011b, 2013); Almeida (2010, 2012); Costa (2008, 2012); Leher (2004, 2013); Catani, Hey e Gilioli (2006); Paula (2006); Amaral e Oliveira (2011), entre outros.

O Programa Universidade para Todos surge em um contexto marcado pela forte expansão das IES privadas, beneficiadas pela legislação sobre educação superior brasileira, que facilitou a abertura e a manutenção de entidades de caráter privado - especialmente as de fins lucrativos (ALMEIDA, 2012). Por outro lado, também era um momento em que a democratização do acesso ao ensino superior era uma questão latente, pois apenas $10,7 \%$ das pessoas de 18 a 24 anos frequentavam o ensino superior na época (2004), segundo dados do 
Censo da Educação Superior do Instituto Nacional de Pesquisas Educacionais Anísio Teixeira (INEP).

Portanto, foi possível perceber que os debates com relação ao ProUni giram em torno de temas como a democratização do acesso, a inclusão e mobilidade social que a política traz como premissas, pois há critérios para a concessão de bolsas de estudo que envolvem renda, raça/cor e etnia; a polêmica questão da isenção fiscal que é concedida às instituições de ensino participantes, em troca das bolsas; e o consequente fortalecimento do setor privado em detrimento do setor público.

A partir da revisão, foram sintetizados alguns pontos cruciais da discussão do tema, em que pesem seus aspectos criticados e defendidos ${ }^{1}$. Entre as críticas mais comuns ao ProUni, destacam-se:

- O ProUni seguir o receituário neoliberal, não modificando a lógica de mercadorização que a educação superior brasileira possui como característica central; ou seja, o Programa privilegia o setor privado em detrimento do setor público, e concede benefícios na forma de isenções fiscais, que agravam o problema;

- O ProUni como uma política transitória, sem capacidade de mudança real das estruturas da sociedade, ou mesmo caminhar em direção à universalização do direito à educação;

- A política foca apenas o acesso, mas não a permanência, sendo este um ponto frágil para os beneficiários do Programa;

- Os cursos que ofertam bolsas pelo ProUni podem ter qualidade questionável, bem como as instituições que os oferecem, além de existir uma grande heterogeneidade institucional na participação do Programa.

Com relação aos pontos de defesa do Programa, embora essa seja uma dimensão menos abordada pelas pesquisas acadêmicas levantadas, são em síntese:

- O ProUni, em que pese seu viés ligado ao setor privado, possui caráter de ação afirmativa, buscando promover a democratização do acesso à educação superior para as camadas menos favorecidas da sociedade;

- A política possui um caráter emergencial e/ou provisório para atender à demanda reprimida pelo acesso ao ensino superior, levando-se em conta que a expansão do setor público educacional é um processo complexo e de longo prazo;

\footnotetext{
${ }^{1}$ Um detalhamento maior destes aspectos pode ser encontrado no Capítulo 2 - O Programa Universidade para Todos (ProUni).
} 
- Pela dimensão social, o ProUni gera a possibilidade de ascensão, mobilidade, ampliação de horizontes e perspectivas (culturais, de conhecimento, de relações, etc.), inclusive com efeito social positivo nas famílias e comunidades dos beneficiários.

Um importante aspecto identificado na revisão bibliográfica, apontado por autores como Catani, Hey e Gilioli (2006), Carvalho (2006) e Almeida (2010, 2012) é, sem dúvida, a falta de estatísticas desagregadas e séries históricas sobre o Programa, o que permitiria uma análise mais abrangente sobre seus impactos. O Ministério da Educação (MEC) disponibiliza oficialmente apenas alguns dados gerais, como, por exemplo, o número de bolsas ofertadas a cada semestre e por Unidade da Federação. Os autores constataram que havia pouca ou nenhuma informação oficial disponível, por exemplo, sobre as IES participantes, os cursos e áreas de concentração que ofertam bolsas, regionalização das bolsas ofertadas e dos bolsistas participantes, número de bolsas ocupadas e/ou ativas, taxas de evasão, ou mesmo o perfil socioeconômico dos bolsistas. Dado este quadro, grande parte das pesquisas acadêmicas que buscaram analisar os impactos do ProUni optou por utilizar métodos qualitativos de pesquisa, majoritariamente por meio de entrevistas com os bolsistas; tais estudos são de extrema importância e trazem uma abordagem bastante rica de detalhes, porém sem a abrangência de um estudo quantitativo.

Nesse sentido, a instituição da Lei de Acesso à Informação ( $n^{\circ} 12.527$, de 18 de novembro de 2011), que entrou em vigor em 2012, tornou possível obter desde então novas informações e estatísticas sobre o ProUni, mediante solicitação ${ }^{2}$ junto ao órgão responsável (MEC). Para esta pesquisa, foram solicitadas informações referentes aos tipos de cursos que ofertaram bolsas, as IES ofertantes, tipos de bolsa (integral ou parcial), turno, regionalização (por Unidade Federativa e município), entre outras.

Por meio deste processo, foi possível obter informações sobre o ProUni com um nível maior de desagregação do que as disponibilizadas oficialmente. A exploração dos dados possibilitou identificar que algumas lacunas de pesquisa apontadas na revisão bibliográfica sobre o ProUni poderiam ser problematizadas a partir dessas informações. No que tange, por exemplo, ao conhecimento dos cursos e IES que ofertam bolsas, já se encontram inúmeras possibilidades de pesquisa.

Portanto, dentre as diversas formas de investigação da política do Programa Universidade para Todos, após as leituras sobre o tema e a abertura de novas possibilidades de

\footnotetext{
${ }^{2}$ O processo de solicitação para a obtenção dos dados é realizado no Sistema Eletrônico do Serviço de Informação ao Cidadão (E-SIC), de forma online.
} 
pesquisa pela exploração dos dados recebidos, foi realizada a opção por investigar um ponto central da política: a qualidade dos cursos que ofertam bolsas pelo ProUni. Este é um ponto bastante questionado na literatura, pois ainda há muitos entraves para se mensurar a qualidade e a relevância social dos cursos ofertados, bem como das instituições que os ofertam. Para Almeida (2012, p. 252), ocorre uma "heterogeneidade educacional das instituições às quais os bolsistas são encaminhados". Paula (2006) e Catani, Hey e Gilioli (2006) mencionaram, à época de criação da política, que os cursos superiores ofertados pelo Programa poderiam oferecer qualidade menor, ou até mesmo questionável, já que as IES privadas não possuem ênfase na pesquisa e extensão, como as IES públicas.

Diversas problematizações foram geradas sobre os cursos que ofertam bolsas pelo ProUni, especialmente no que tange à qualidade e avaliação dos mesmos. Perguntas como: quais são os cursos ofertados? Quais Instituições de Ensino Superior os ofertam? Estes cursos e instituições possuem qualidade (e sobre qual noção de qualidade se está discutindo?), ainda permeiam as questões a serem investigadas sobre o ProUni, cujos dados não eram até então disponibilizados oficialmente, inviabilizando pesquisas mais aprofundadas.

Diante da possibilidade de exploração de dados sobre os cursos do ProUni e sua identificação por IES participante, e considerando-os valiosos e ainda pouco utilizados em trabalhos sobre o tema, esta pesquisa se debruçou em uma análise acerca da qualidade dos cursos que participam do Programa.

Sobre esse aspecto, foi constatado que a legislação do ProUni não explicita diretamente ${ }^{3}$ sobre qual instrumento é utilizado como indicador de qualidade para avaliação dos cursos superiores oferecidos pelo Programa, embora utilize critérios de desempenho do SINAES, o sistema vigente de avaliação da qualidade da educação superior no país. Verificou-se que estes processos ainda são pouco conhecidos e investigados quanto à sua validade; nesse sentido, surgem diversos questionamentos: a avaliação dos cursos com oferta de bolsas pelo ProUni consegue realizar-se efetivamente e assegurar um padrão mínimo de qualidade? Quais critérios são efetivamente utilizados?

\footnotetext{
${ }^{3}$ Conforme consta na Lei do ProUni: “O Ministério da Educação desvinculará do ProUni o curso considerado insuficiente, sem prejuízo do estudante já matriculado, segundo critérios de desempenho do Sistema Nacional de Avaliação da Educação Superior - SINAES, por duas avaliações consecutivas [...]" (BRASIL, 2005a, Art. $7^{\circ}$ $\S 4^{\circ}$ ). No entanto, não há menção sobre qual indicador é utilizado para essa avaliação dos cursos. Na legislação correlata, foi encontrada uma descrição sobre os critérios de avaliação apenas nas Portarias Normativas que regulamentam os procedimentos de adesão de mantenedoras de instituições de educação superior ao ProUni, em que são abordados parâmetros de avaliação dos cursos para o oferecimento de bolsas adicionais (oferecidas pelas instituições além das obrigatórias por lei), mas não foi encontrada nenhuma menção sobre a avaliação dos cursos que ofertam bolsas regulares.
} 
Para discutir a questão da qualidade dos cursos do ProUni, foi realizado o cruzamento das informações sobre os cursos que participaram do ProUni, com os resultados de avaliação desses cursos obtidos no âmbito do SINAES. Como não foi encontrada determinação clara a respeito de qual critério é utilizado oficialmente, foram utilizados nesta pesquisa os resultados de avaliação do Conceito Preliminar de Curso (CPC), indicador que é considerado, oficialmente, o Indicador de Qualidade da Educação Superior voltado aos cursos superiores brasileiros, uma das "medidas da qualidade dos cursos [...] do país, utilizados tanto como referenciais no desenvolvimento de políticas públicas para a Educação Superior quanto como fonte de consultas pela sociedade" (BRASIL, 2013a, p. 5). Portanto, cabe ressaltar que a referência de qualidade da educação superior utilizada neste trabalho foi a noção de qualidade oficial estabelecida no âmbito do SINAES - questão que, por outro lado, não impediu sua posterior problematização.

O objetivo geral deste trabalho foi, então, analisar a questão da qualidade dos cursos que ofertaram bolsas pelo Programa Universidade para Todos (ProUni), a partir dos resultados de avaliação de cursos do SINAES.

Os objetivos específicos foram:

- Levantar e analisar informações do ProUni a respeito da composição dos cursos que ofertaram bolsas em seu(s) processo(s) seletivo(s), bem como questões relativas à oferta destes cursos, tais como: áreas de concentração, Instituições de Ensino Superior ofertantes, regiões geográficas, tipos de bolsa, modalidades de ensino, processos de avaliação, etc.

- Relacionar os cursos que ofertaram bolsas pelo ProUni, nos determinados processos seletivos pesquisados, com os resultados de avaliação dos cursos de graduação obtidos por meio do Conceito Preliminar de Curso (CPC).

- A partir da análise realizada entre os dados do ProUni e os resultados de avaliação de cursos do CPC, problematizar os resultados considerando a discussão sobre qualidade e avaliação da educação superior brasileira, levando em conta os limites e possibilidades conceituais nesse contexto.

Com relação aos procedimentos metodológicos, a primeira parte do desenvolvimento da dissertação se deu pela revisão sistemática da literatura sobre o tema, e de outros inerentes ao mesmo, constituindo assim o passo fundamental desta pesquisa, que é de cunho exploratório; tal processo auxiliou a “[...] seleção de um problema específico, ajudar em sua delimitação, 
mostrar sua relação com pesquisas realizadas anteriormente e colaborar na seleção de técnicas para sua investigação" (MOURA e FERREIRA, 2005, p. 35). Também foi realizada uma análise documental das legislações que orientam o ProUni, o SINAES e outras diretrizes relativas à educação superior.

A segunda parte da pesquisa (embora a revisão sistemática da literatura e dos documentos tenha se mantido ao longo de todo o percurso) compreendeu o uso de técnicas quantitativas, por meio do uso de dados secundários sobre o ProUni obtidos junto ao MEC por meio da Lei de Acesso à Informação, e do Conceito Preliminar de Curso, disponibilizados pelo INEP. Foi utilizado o software Microsoft Excel para o processamento dos dados.

Com relação às informações obtidas sobre os cursos que ofertaram bolsas pelo ProUni, é necessário ressaltar que são dados referentes ao processo seletivo do primeiro semestre de 2014, sendo estabelecido também um recorte geográfico, para os cursos do município de São Paulo $-\mathrm{SP}^{4}$.

Esta dissertação foi organizada em três capítulos, considerando quatro temas essenciais: a trajetória do setor de educação superior; as políticas de avaliação da educação superior no Brasil, em especial o SINAES; a discussão conceitual sobre qualidade da educação superior, inserida nesse contexto; e o debate sobre o Programa Universidade para Todos, com o objetivo de reunir arcabouço teórico para orientar e fundamentar as discussões que surgiram no desenvolvimento da pesquisa.

Portanto, no Capítulo 1, trata-se na primeira seção da trajetória da educação superior, englobando suas principais fases e movimentos de expansão, com destaque para o período mais recente (2000-2015). Na segunda seção, é abordada a história da avaliação da educação superior no país, com ênfase na instituição do SINAES, em 2004. Na terceira seção, é discutida a questão da qualidade da educação superior, com o objetivo de trazer as diferentes abordagens conceituais e refletir sobre de que forma a qualidade se relaciona com as políticas de avaliação da educação superior no Brasil, explicitando alguns dos limites e possibilidades decorrentes desse processo.

No Capítulo 2 apresenta-se o tema central da dissertação, a política do Programa Universidade para Todos (ProUni), visando compreender seu funcionamento, operacionalização e os principais debates da literatura relacionada, assim como foi realizada

\footnotetext{
${ }^{4}$ A razão da escolha desse processo seletivo, bem como do recorte geográfico, foi devido à grande quantidade de dados a serem trabalhados, e também por ser o último processo seletivo até a data da solicitação (que ocorreu entre os meses de março e abril de 2014).
} 
uma análise dos dados sobre a abrangência dessa política, tais como: número de bolsas ofertadas, perfil dos bolsistas, regiões geográficas, cursos e IES participantes.

No Capítulo 3, foram reunidas as informações disponíveis para subsidiar a discussão sobre a qualidade dos cursos que ofertaram bolsas no Programa Universidade para Todos. Primeiramente, foi realizada uma revisão bibliográfica acerca dos principais aspectos que norteiam o Conceito Preliminar de Curso, como a metodologia de construção do indicador e o debate acadêmico que surgiu desde sua criação. Em seguida, problematiza-se sobre como é realizado o processo de avaliação dos cursos que ofertam bolsas pelo ProUni e quais são os critérios empregados, resgatando a legislação correlata. Por fim, a última seção traz a metodologia e os resultados da análise que compreendeu o cruzamento dos dados do CPC em relação aos dos cursos que ofereceram bolsas do ProUni no processo seletivo selecionado.

Por fim, são apresentadas as Considerações Finais desta pesquisa, em que se levantam as possíveis problemáticas decorrentes da análise dos dados, à luz do debate teórico e do levantamento bibliográfico dos capítulos anteriores. 


\section{CAPÍTULO 1 - EDUCAÇÃO SUPERIOR, AVALIAÇÃO E QUALIDADE}

Neste Capítulo, serão tratados três temas que permeiam esta dissertação: a trajetória da educação superior e as políticas de avaliação da educação superior no Brasil, além da discussão conceitual sobre qualidade, inserida nesse contexto. O objetivo é reunir arcabouço teórico para orientar e fundamentar as discussões da pesquisa.

Na primeira seção, são tratados os principais acontecimentos em torno da história da educação superior brasileira, destacando as principais fases e movimentos de expansão, especialmente desde a sua "última grande reforma" (SILVA JÚNIOR e SGUISSARDI, 2001, p. 177), a Reforma Universitária de 1968. É realizada uma discussão em torno das principais temáticas que envolvem a área, como: a expansão e a consolidação do setor, os conflitos em torno da participação dos setores público versus privado, e o destaque para o período mais recente (2000-2015), que engloba um novo ciclo de transformações, por meio da retomada de investimentos no segmento público federal e da promoção do ensino a distância, bem como das políticas que visam a democratização do acesso e a inclusão social a esse nível educacional momento em que surge também a política governamental que é objeto de estudo deste trabalho, o Programa Universidade para Todos (ProUni).

Na segunda seção, é abordada a história da avaliação da educação superior no país desde seu início, em meados da década de 1980, até os dias atuais, com a instituição do Sistema Nacional de Avaliação da Educação Superior (SINAES), em 2004.

Por fim, na terceira seção é discutida a questão da qualidade da educação superior, cujo objetivo foi trazer as diferentes visões em torno desse conceito, e, de forma a embasar as investigações desta pesquisa, discutir de que forma a qualidade se relaciona com as políticas de avaliação da educação superior no Brasil, explicitando alguns dos limites e possibilidades decorrentes desse processo.

\subsection{Histórico da Educação Superior brasileira: principais acontecimentos}

\subsubsection{Da criação da primeira universidade (1920) à Reforma Universitária de 1968}

Pode-se dizer que a educação superior ocorreu de forma tardia no Brasil - em relação a outros países da América Latina e os Estados Unidos -, com o nascimento oficial ${ }^{5}$ da primeira

\footnotetext{
${ }^{5}$ Ocorreram tentativas anteriores para a criação de universidade no Brasil; porém, essa história é marcada por resistência, desde a Colônia até o Império - tanto por Portugal, quanto pela elite instalada no país, que considerava mais adequado buscar estudos superiores na Europa (FÁVERO, 2006).
} 
universidade apenas em 1920. Era em um contexto nacional marcado por transformações sociais, culturais e políticas, imbricando em maior conscientização sobre as questões educacionais, em um espaço onde predominavam escolas isoladas ${ }^{6}$ de ensino superior (ROSSATO, 2006; FÁVERO, 2006). Nesse período surgiram as Universidades: do Rio de Janeiro (1920), de Minas Gerais (1927), Técnica de Rio Grande do Sul (1932), de São Paulo (1934) e do Distrito Federal (1935-1939) (BARREYRO, 2008a). Com a implantação do Estado Novo em 1937, o governo fortaleceu-se em um período marcado por autoritarismo, censura e a repressão. Nesse contexto, foram priorizadas políticas econômicas que envolveram o nacionaldesenvolvimentismo e a substituição de importações, promovendo industrialização ao país (ROSSATO, 2006; CUNHA, 2007). Ainda no Estado Novo, podem ser apontadas como características importantes o populismo do então presidente Getúlio Vargas, o nacionalismo e a forte presença do Estado na política, economia e cultura.

No fim do Estado Novo (1945), o país contava com cinco universidades, sendo duas estaduais e três federais (CUNHA, 2007). Naquele momento, o país sofreu um processo de abertura política e econômica, principalmente devido ao contexto externo da Guerra Fria. Em 1951, Vargas voltou ao poder, realizando o intervencionismo estatal associado ao nacionalismo econômico. Posteriormente, com Juscelino Kubitschek (1956-1960), ocorreu forte associação entre capital estrangeiro e desenvolvimento industrial brasileiro, por meio do Plano de Metas (ROSSATO, 2006), momento em que o país abriu as portas de diversos setores para a desnacionalização da economia. Nessa ocasião, ocorreram diversas transformações educacionais do país, setor que necessitava adequar-se às novas demandas e exigências da sociedade. Essa adequação, entretanto, deve ser entendida, de acordo com Rossato (2006, p. 34) na perspectiva em que "a educação deve ser analisada segundo o jogo de forças e interesses político-econômico vigentes, com a função de preservar a ordem [...]”.

No contexto que sucedeu o Estado Novo, compreendido pela Constituição de 1946 dotada de espírito liberal após 15 anos de ditadura (ROSSATO, 2006) -, foi aprovada a Lei n $^{\circ}$ 4.024, de 20 de dezembro de 1961 - a primeira Lei de Diretrizes e Bases da Educação Nacional (LDB), que indicou regulamentações no sentido de expansão dos segmentos de educação superior, dando autonomia às universidades e aos conselhos de educação. Também em 1961, foi criado o Conselho Federal de Educação (CFE), que ficou com a função de aprovar ou reprovar a abertura de cursos e estabelecimentos isolados de ensino superior e monitorar o

\footnotetext{
${ }^{6}$ Já existiam na época outros estabelecimentos isolados desse nível educacional, como escolas de nível superior (escolas de direito, medicina, engenharia, etc.). As próprias universidades que foram criadas na época caracterizavam-se, em sua maioria, pela aglutinação desses estabelecimentos isolados (CUNHA, 2007).
} 
funcionamento de todos esses estabelecimentos - neste momento, também, foram instituídos os requisitos mínimos para o funcionamento dos locais de ensino superior (CUNHA, 2007)

Entretanto, a LDB de 1961 foi considerada conservadora e pouco invasiva no quesito da educação superior da época, já que foi idealizada segundo interesses claramente elitistas, além de ter foco maior no ensino médio. Para Rossato (2006), os níveis médio e superior de ensino mantiveram uma estrutura elitista, representando uma dicotomia educacional. Apesar destes fatores, a LDB influenciou a flexibilização da estrutura de ensino e possibilitou um maior acesso às universidades, mesmo que ainda fosse reduzido em comparação à população geral. A LDB foi considerada para Teixeira (1962) uma meia vitória, pois apesar de se concretizarem algumas mudanças, não foi possível transformar o cenário de anacronismo educacional.

No período compreendido entre 1945 a 1964, a educação superior foi marcada por notável crescimento e modernização, acompanhando as mudanças no desenvolvimento do país. No final de 1964, foram contabilizadas 39 universidades, principalmente pela aglutinação de escolas isoladas de nível superior, além de 564 estabelecimentos isolados. As matrículas públicas saltaram de 21 mil para 182 mil (MARTINS, 2009). Para o autor, era importante que as universidades federais aumentassem o seu número de vagas, sobretudo nos cursos de alto custo - medicina e engenharia, que eram os principais da época. Naquele momento, a participação do setor privado se mantinha estável, detendo aproximadamente $44 \%$ das matrículas, segundo Martins.

Contudo, após 1964, Rossato (2006) aponta que a educação superior pública encontrava-se incapaz de absorver a demanda, já que a oferta de vagas ainda era inexpressiva com relação ao volume da população no país - dada a maior oferta de empregos e necessidades do mercado, além da classe média em ascensão que competia por postos elevados. A consequência desse movimento foi a maior seletividade nos exames vestibulares, criando-se excedentes (aprovados que não conseguiam vagas nas Universidades) e uma forte pressão social para a expansão do ensino, já que "tratavam-se de membros da classe média em geral buscando algum canal de ascensão social” (SILVA JÚNIOR e SGUISSARDI, 2001, p. 186). Jovens professores e o movimento estudantil da época se posicionavam pela criação de universidades públicas não-elitizadas e organizadas por departamentos, onde haveria uma decisão mais democrática por parte dos docentes, livre das cátedras (MARTINS, 2009). Segundo os autores, as pressões e mobilizações do movimento estudantil tomavam proporções cada vez maiores.

Após a tomada do poder pelos militares, movimento também referido como o golpe de 1964, o cenário político ficou marcado pelo autoritarismo, que fazia parte do modelo político- 
econômico implantado e que inclusive impactou de forma direta a formulação de políticas educacionais. A doutrina ideológica que guiava o período era marcada por forte imposição dos militares, que "se caracterizava pelo espírito de homogeneidade e da ordem. O governo se distanciou da sociedade civil e dos sindicatos, os partidos políticos e movimentos estudantis foram esvaziados" (ROSSATO, 2006, p. 60). Diante dessa organização, o Estado assumiu, mais do que nunca, a função totalizadora e centralizadora do poder. Nesse contexto, as universidades se tornaram ingerência direta do governo federal, onde as atividades de caráter contrário a esta política eram objeto de repressão constante, principalmente em relação ao movimento estudantil; além disso, muitos professores com opiniões contrárias à ordem estabelecida foram sendo afastados de seus cargos. Diversos dispositivos legais repressivos foram acionados na época, como por exemplo, um decreto de extinção da União Nacional dos Estudantes (UNE), que havia sido criada em 1938 e era um importante canal de reivindicação estudantil (MARTINS, 2009).

Duas medidas governamentais que visaram a adequação das universidades aos modelos da época ilustram bem esse contexto: o Plano Atcon e a Comissão Meira Mattos. O Plano Atcon foi um estudo realizado pelo consultor americano Rudolph Atcon, em 1965, a convite do Ministério da Educação e Cultura. Esse estudo ficou marcado por preconizar "a implantação de nova estrutura administrativa universitária baseada no modelo empresarial, cujos princípios básicos deveriam ser o rendimento e a eficiência" (FÁVERO, 1991, p. 8). Já a Comissão Meira Mattos foi criada pelo Governo, em 1967, para emitir pareceres sobre questões relacionadas às atividades estudantis e em relação às instituições de ensino. Entre outras questões, o papel da Comissão era, além de conter as reivindicações do movimento estudantil da época, propor reformas modernizadoras para as instituições, segundo os moldes burocráticos e empresariais. No documento de Atcon e no Relatório produzido pela Comissão era possível perceber que "a universidade foi 'convertida' em problema político e social e precisava ser 'modernizada' e reformada, para acabar com qualquer possibilidade de contestação" (FÁVERO, 1991, p. 8).

Nessa conjuntura foi originada a Reforma Universitária, da Lei ${ }^{\circ} 5.540$, de 28 de novembro de 1968, com o objetivo de associar propostas de modernização e expansão do ensino superior, de forma a adequar as universidades às novas estruturas políticas do país, e também aos interesses do regime militar e seu novo modelo de desenvolvimento - o que, com o crescimento de setores da economia, apontava a necessidade de maior escolarização do 
brasileiro $^{7}$ via educação superior, visando atender a metas de desenvolvimento nacional. No entanto, dado ao contexto político, "a política educacional seria confiada a um pequeno grupo designado pelo poder central” (MARTINS, 2009, p. 19). Para Silva Júnior e Sguissardi (2001), a Reforma de 68 contribuiu para

[...] integrar a educação superior às orientações do novo projeto de desenvolvimento. Era necessário despolitizar o campo acadêmico, neutralizar as ações de contestação do movimento estudantil, ligado a organizações populares, e mantê-lo sob rígido controle (SILVA JÚNIOR e SGUISSARDI, 2001, p. 181).

A Reforma apontou diversas mudanças na organização acadêmico-administrativa das universidades e estabelecimentos isolados do país. Para Martins (2009, p. 16), “a Reforma de 1968 produziu efeitos paradoxais no ensino superior brasileiro", pois modernizou universidades federais e instituições estaduais e confessionais e também criou condições - até então pouco propícias -, para a articulação de ensino e pesquisa em certas instituições. Na intenção de racionalizar os processos e reduzir custos, recomendou-se a extinção de cátedras vitalícias, a criação de departamentos, entre outros mecanismos. Para o autor, além de outras mudanças, com a Reforma foi criada uma política nacional de pós-graduação. Por outro lado, a Reforma reservou espaço significativo para a participação do setor privado no processo expansionista, pois, ao visar a ampliação do número de vagas, também contribuiu para a expansão desse segmento na educação superior - que, é importante ressaltar, já existia antes, porém de forma diferenciada, já que, de acordo com Martins (2009), organizava-se de maneira semelhante ao ensino público no período anterior à Reforma de 68. Após a Reforma, foi estimulada a criação e a manutenção de universidades particulares. Portanto, para o autor

Se a Reforma de 1968 produziu efeitos inovadores, por outro lado, abriu condições para o surgimento de um ensino privado que reproduziu o que Florestan Fernandes denominou o antigo padrão brasileiro de escola superior, ou seja, instituições organizadas a partir de estabelecimentos isolados, voltados para a mera transmissão de conhecimentos de cunho marcadamente profissionalizante e distanciados da atividade de pesquisa [...] (MARTINS, 2009, p. 17, grifo do autor).

\footnotetext{
7 Também foi um forte marco para as políticas educacionais da época a Teoria do Capital Humano, dos quais o teórico de maior destaque foi Schultz (1973), cujos preceitos, de base economicista, estabelecem que é necessário investir não apenas no capital físico, mas também no capital humano, ou seja, na escolaridade dos indivíduos de uma sociedade, em níveis educacionais mais altos. A teoria relaciona diretamente o desenvolvimento e a educação - quanto maior o grau de instrução, maior a produtividade e a renda. Frigotto (1995) faz críticas a essa abordagem, afirmando que essa teoria reduz a concepção de educação a um fator econômico, do processo de produção, abstraída das demais relações de poder da sociedade.
} 
Na mesma linha de pensamento, Rossato (2006) também postula que

[...] a reforma universitária, que buscava atender, de um lado, à demanda e pressão social, e de outro, formar recursos humanos adequados ao processo de modernização e desenvolvimento, encaminhou-se para uma solução quantitativa em detrimento da qualidade, para a instalação de estabelecimentos isolados, em vez de universidades, e para a abertura à iniciativa privada com omissão do público (Estado) (ROSSATO, 2006, p. 7576).

Portanto, por meio dessa expansão quantitativa e de estabelecimentos isolados, o setor privado foi responsável por protagonizar a expansão no atendimento da massa estudantil no final dos anos 1960 e durante toda a década de 1970. Sintetiza-se que, no período, os efeitos do “economicismo na política educacional, reforçado pela ideologia do regime militar, se expressaram, negativamente, de várias formas: pelo desmantelamento da escola pública e reforço da educação como negócio" (FRIGOTTO, 1995, p. 19). Nesse processo, a questão da qualidade da educação superior no país foi deixada de lado, quadro que se estendeu e gerou consequências para as décadas seguintes.

Na década de 1970, predominou no Brasil a imagem do chamado "milagre econômico", situação em que o desenvolvimento, em tese, teria sido atingido, assim como o bem-estar da população. Esse milagre teria sido obtido por intermédio de medidas econômicas instauradas no país que visavam a abertura ao capital estrangeiro, o aumento das exportações e a crescente presença do Estado na economia. Por outro lado, o período foi marcado por intensa concentração econômica (ROSSATO, 2006). No período compreendido entre 1965-1980, as matrículas do setor privado foram de 142 mil para 885 mil alunos (MARTINS, 2009, p. 23), ocorrendo de forma mais evidente o "primeiro grande movimento de privatização do sistema" (SGUISSARDI, 2008, p. 998, grifo do autor).

Em contraponto, a partir de 1974, ocorreu um processo de contenção da expansão da educação superior, que teve que se reorganizar por razões da conjuntura econômica e outros fatores intrínsecos à área educacional; esse processo perdurou até 1990. Explica-se essa contenção, primeiramente, com o esgotamento do milagre econômico afetado pela crise internacional, o que gerou aumento das taxas de desemprego, de inflação, perdas salariais, entre outros fatores, o que consequentemente ocasionou um desaquecimento do setor de educação superior. Além disso, conforme destacam Rossato (2006) e Silva Júnior e Sguissardi (2001), o Governo Federal também tentou conter a expansão do ensino superior privado frente à crescente 
pressão de vários segmentos da sociedade civil, críticos à qualidade educacional, que apresentava um quadro pouco preciso frente ao forte processo expansionista anterior. Na esfera legal, alguns dispositivos ${ }^{8}$ também foram adotados para restringir a criação de cursos desse nível educacional.

O regime militar terminou com fortes críticas, principalmente sob a ameaça de desemprego iminente. Nessas condições, iniciou-se a Nova República com a eleição de Tancredo Neves (1985), que posteriormente faleceu, assumindo então José Sarney ainda no mesmo ano. Nesse contexto, a política voltou-se para combater a inflação, decorrendo então uma sucessão de planos estabilizadores. Por meio de acordos internacionais entre os países, que passavam a ser um dos pilares do novo modelo econômico baseado na globalização, o Brasil passa a tomar empréstimos do Fundo Monetário Internacional (FMI), que em contrapartida passou a influenciar a formulação de políticas internas dos países a quem emprestava recursos, iniciando-se as reformas e um novo ciclo de abertura política no Brasil.

Nesse sentido, de acordo com Silva Júnior e Sguissardi (2001) ficou bastante evidente no período uma forte articulação do Estado brasileiro com organismos multilaterais, como o próprio FMI, mas também com o Banco Internacional para Reconstrução e Desenvolvimento (BIRD) e o próprio Banco Mundial ${ }^{9}$, momento em que “os responsáveis pela política educacional no país incorporaram determinados princípios das agendas de organismos internacionais" (MARTINS, 2009, p. 25). Entre essas recomendações, incluiu-se a desregulamentação da educação superior e a diminuição de gastos governamentais para o setor, em busca de equilíbrio orçamentário no país. Neste cenário, foram iniciadas amplas reformas visando racionalizar os custos de setores estratégicos da sociedade, em especial nos sistemas de saúde, educação e previdência.

\footnotetext{
${ }^{8}$ Destaque para os Decretos: $n^{\circ} 86.000 / 81$, revogado em 1982, que suspendeu temporariamente a criação de novos cursos de graduação em universidades e estabelecimentos isolados federais; o Decreto $\mathrm{n}^{\circ}$ 91.694/85, que proibia a criação de novos cursos de Direito em todo o território nacional até 1986; o Decreto ${ }^{\circ}$ 93.594/86, que sustava a criação de novos cursos superiores de graduação até 1987, prorrogado pelos Decretos $n^{\circ} 95.003 / 87$ até 1988 , e $\mathrm{n}^{\circ}$ 97.881/89 até 1989 (SOUSA, 2003).

${ }^{9}$ Muitas pesquisas educacionais apontam que, no período citado, ocorreu forte interação entre as políticas internacionais de organismos multilaterais e a agenda política brasileira, o que certamente impactou as políticas formuladas nesse contexto. Entretanto, é importante ressaltar que este trabalho está de acordo com Barreto e Leher (2008, p. 423), que argumentam que essas associações entre as recomendações dos organismos internacionais e as políticas instituídas no país não devem ser diretas e simplistas, devendo considerar que "essas condicionalidades impostas pelos organismos internacionais aos países 'em desenvolvimento' ou 'em transição' são 'traduzidas e adaptadas' no enredo das formulações locais, compreendendo a dimensão material e a simbólica das disputas por hegemonia". Ou seja, deve-se considerar a correlação de forças também existente previamente no país, com interesses já consolidados de setores como a burguesia local, por exemplo - e como isso influenciou o rumo das políticas adotadas.
} 


\subsubsection{Reformas educacionais a partir da década de 1990: movimentos de expansão e privatização $^{10}$ da Educação Superior}

As diversas reformas governamentais, que estão relacionadas à inserção de ideias neoliberais na política econômica do país, têm início a partir do Governo Collor, que assumiu a presidência em 1990. O modelo econômico neoliberal influenciou seu programa de governo, que se baseava fundamentalmente na abertura de mercado e diminuição dos gastos públicos, realizando a privatização de empresas produtivas estatais (COSTA, 2008). Após um processo que levou ao seu impeachment em 1992, assumiu a presidência o vice Itamar Franco, que convidou Fernando Henrique Cardoso (FHC) para ser Ministro da Fazenda em 1993. A estadia de FHC no Ministério, e posteriormente sua vitória nas eleições para a Presidência, em 1995, aprofundaram a reforma do Estado e intensificaram ainda mais as medidas privatizantes, inclusive com bastante peso no setor educacional (DOURADO, 2002). Esse modelo econômico “deixa clara a visão de políticas públicas enquanto uma área que deveria ser compartilhada com o mercado, minimizando gastos e contribuindo assim para a superação da 'crise' econômica" (COSTA, 2008, p. 41)

$\mathrm{Na}$ esteira das transformações econômicas e políticas do período, e à sombra das recomendações do Banco Mundial (SGUISSARDI, 2008) a instituição da Lei de Diretrizes e Bases da Educação Nacional (LDB), n 9.394, de 20 de dezembro de 1996, trouxe diversas mudanças, especialmente em seu capítulo IV intitulado "Da educação superior" - dentre as mais marcantes, a diversificação institucional, como mostra o Artigo 45: “A educação superior será ministrada em instituições de ensino superior, públicas ou privadas, com variados graus de abrangência ou especialização" (BRASIL, 1996). Nesse âmbito, as instituições privadas de ensino passaram também a ser classificadas em novas categorias:

As instituições privadas de ensino se enquadrarão nas seguintes categorias: I - particulares em sentido estrito, assim entendidas as que são instituídas e mantidas por uma ou mais pessoas físicas ou jurídicas de direito privado que não apresentem as características dos incisos abaixo;

II - comunitárias, assim entendidas as que são instituídas por grupos de pessoas físicas ou por uma ou mais pessoas jurídicas, inclusive cooperativas educacionais, sem fins lucrativos, que incluam na sua entidade mantenedora representantes da comunidade;

\footnotetext{
${ }^{10} \mathrm{O}$ conceito de privatização, quando relacionado à educação superior, não é utilizado neste trabalho (exceto quando mencionado por outros autores) em sua acepção comum do termo, ou seja, o deslocamento de empresas do setor público para o setor privado; mas sim, na lógica da priorização de investimentos para o setor privado em detrimento do setor público, e/ou o favorecimento governamental ao crescimento do setor privado com fins de lucro (BARREYRO e COSTA, 2015).
} 
III - confessionais, assim entendidas as que são instituídas por grupos de pessoas físicas ou por uma ou mais pessoas jurídicas que atendem a orientação confessional e ideologia específicas e ao disposto no inciso anterior;

IV - filantrópicas, na forma da lei. (BRASIL, 1996, Art. 20).

Embora o sistema de educação superior já permitisse anteriormente a diferenciação institucional, essas mudanças se aprofundaram de forma bastante evidente a partir da promulgação da LDB de 1996 (DOURADO, 2002), bem como sua legislação correlata, como será observado a seguir.

Além disso, para Silva Júnior e Sguissardi (2001, p. 55), “a LDB é omissa em relação ao princípio da associação ensino, pesquisa e extensão", cuja exigência só seria aplicada para Instituições de Ensino Superior de organização acadêmica ${ }^{11}$ em universidades. Entre outras mudanças, a LDB também facultou a existência de universidades especializadas por campo do saber, o que não existia desde a criação da primeira universidade, em 1920; originou um novo tipo de curso, os cursos sequenciais por campo de saber (até então, somente eram oferecidos cursos de graduação, pós-graduação e extensão), caracterizados por carga horária e duração reduzida em relação aos cursos existentes (CUNHA, 2003).

Não obstante, "a generalidade e a flexibilidade da LDB, como guarda-chuva das reformas pontuais, possibilitam ao MEC editar normas complementares via decretos e portarias" (SILVA JÚNIOR E SGUISSARDI, 2001, p. 55). Dentre estes dispositivos, pode-se destacar o Decreto no 2.207/1997, substituído posteriormente pelo Decreto no 2.306/1997, que distingue as IES brasileiras em públicas, privadas sem fins lucrativos e privadas com fins lucrativos, ou seja, autorizava definitivamente a educação superior a ser passível de comercialização, lucro e acumulação - uma mercadoria, de fato (SGUISSARDI, 2008). Cunha (2003), na mesma linha de pensamento, afirma que esse Decreto estabelece importantes modificações na fronteira público versus privado até então existente na educação superior brasileira.

A facilidade na abertura de cursos, com diferentes tipos de instituições e modalidades, propiciou um movimento em que a educação superior foi sendo conduzida, gradativamente, para a consolidação no setor privado, período também marcado por investimentos cada vez menores na educação superior pública (PAULA, 2006). É possível constatar a rápida proliferação no Gráfico 1, que traz um recorte estatístico entre 1990 e 2000. Em 1990, segundo

\footnotetext{
${ }^{11}$ As Instituições de Ensino Superior, após o processo de abertura de diversificação institucional a partir da LDB de 1996, poderiam ser organizadas academicamente em universidades, faculdades, escolas, institutos, etc., de categorias administrativas públicas ou privadas.
} 
dados do Censo da Educação Superior do Instituto de Pesquisas e Estudos Educacionais Anísio Teixeira (INEP), haviam 918 Instituições de Educação Superior no país, sendo 222 públicas e 696 privadas. Portanto, o setor privado já assumia papel bastante significativo no setor, comportando $75,8 \%$ das IES.

Ao final do ano de 2000, em comparação ao período anterior, esses números eram de 1.180 IES no total, sendo 176 públicas (retração de 21\%); e 1.004 IES privadas (expansão de $44 \%$ ), com o setor privado representando agora $85,1 \%$ das IES desse nível educacional.

\section{Gráfico 1 - Número de Instituições de Ensino Superior e variação anual (em \%), por categoria administrativa (pública e privada)}

Brasil, 1990-2000.

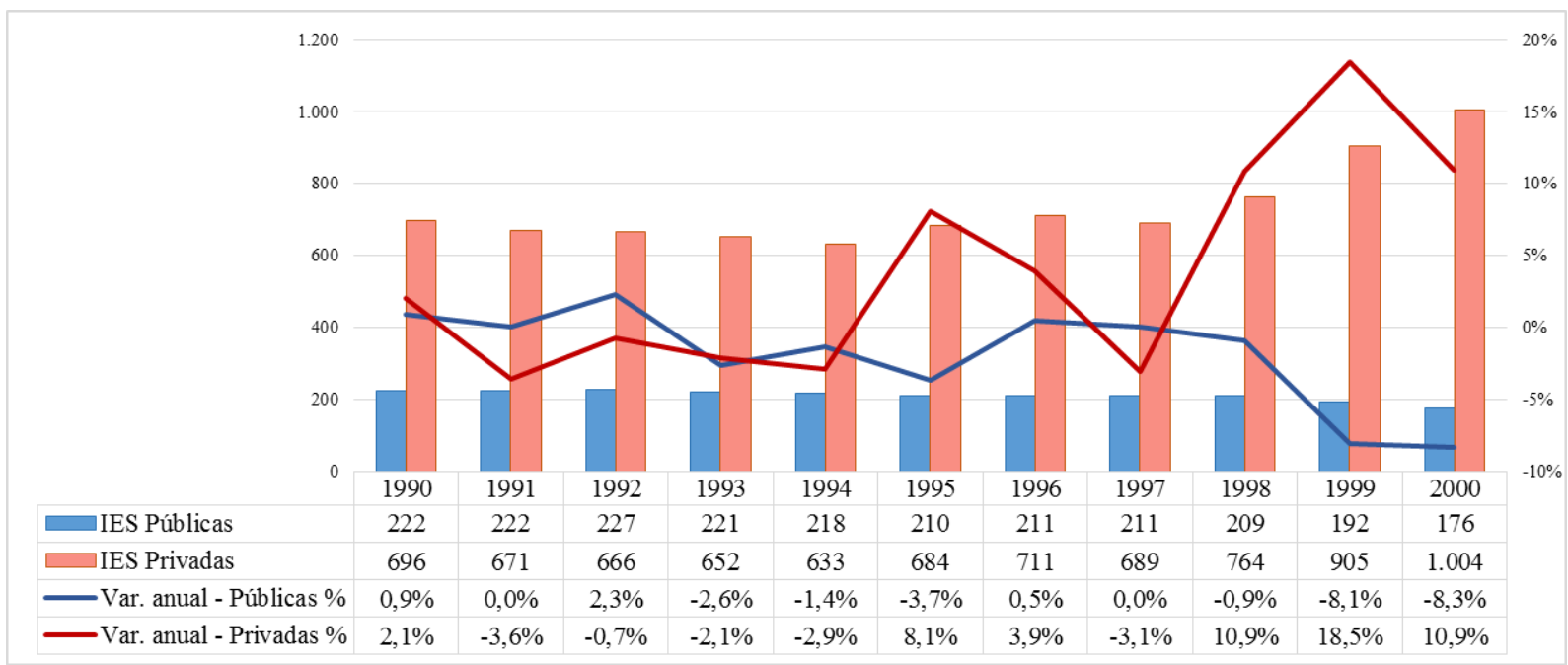

Fonte: INEP - Censos da Educação Superior (BRASIL, 2002, 2005b, 2016a).

Elaboração própria.

Devido à retração de vagas no setor público, a demanda foi sendo absorvida rapidamente pelo setor privado, o que refletiu no aumento vertiginoso não somente de IES, conforme observado, mas também no número de matrículas. Ocorreu um "processo de privatização das matrículas" (SGUISSARDI, 2008, p. 1000), já que nesse período de 10 anos, as matrículas no setor público cresceram $53 \%$, e no setor privado $88 \%$ - essas últimas agora representando $67,1 \%$ do total de matrículas da educação superior.

Dessa forma, as instituições privadas foram absorvendo a demanda de pré-universitários que não conseguiram passar pelos rígidos processos seletivos das universidades públicas, cada vez mais afuniladas no quesito de vagas disponíveis. Estas instituições privadas buscaram, então, ampliar cada vez mais a oferta de vagas, o que para Rossato (2006) acabou deixando de 
lado a atenção suficiente em relação à qualidade de ensino oferecido, principalmente pela ausência de atividades voltadas à pesquisa e/ou ciência e tecnologia.

Esse grande período de muitas transformações educacionais ao longo dos anos 1990, marcado pelo atendimento às lógicas do mercado (PAULA, 2006; SGUISSARDI, 2008; OLIVEIRA, 2009) pode ser sintetizado como um processo que culminou na mercantilização da educação superior e na constituição de uma nova identidade para as IES do setor privado, pois

O setor privado do ensino superior, depois de passar por ampla expansão ao
longo dos anos setenta, ter sua expansão limitada legal e economicamente
durante os anos oitenta e sua qualidade questionada, nesse mesmo período,
entra na presente década sob condições precárias e com suas estratégias de
interferência política debilitadas, face às transformações ocorridas no Brasil.
O Governo, via legislação e políticas educacionais oriundas do Executivo,
induz a uma diferenciação institucional generalizada no âmbito da educação
superior brasileira, ao mesmo tempo que incentiva, pelos mesmos
mecanismos, o processo de mercantilização desse espaço social, mediante
estímulo à concorrência entre as instituições privadas e, em face da
conjuntura, à aproximação com o setor produtivo [...] (SILVA JÚNIOR e
SGUISSARDI, 2001, p. 235).

Este quadro só não se agravou ainda mais em razão de fortes pressões populares, que ocorriam durante o início dos anos 2000 pela ampliação e democratização da educação superior (OLIVEIRA et al., 2006). Eram setores da sociedade que almejavam uma porta de entrada a esse nível educacional sem ter que custear as instituições privadas, caracterizadas por cobrar altas mensalidades, e tampouco submeter-se, sem a preparação adequada, ao rígido modelo do vestibular público. Menos de $12 \%$ da população da faixa etária de 18 a 24 anos, considerada adequada, estava efetivamente cursando esse nível naquele momento (BRASIL, 2001).

Em 2001, após muitos debates (e embates) de diversos setores da sociedade, foi instituído o Plano Nacional de Educação (PNE) - Lei no 10.172, de 09 de janeiro de 2001, que propôs, além de outras metas para diferentes níveis educacionais, a meta de prover acesso à educação superior para, pelo menos, 30\% da população brasileira na faixa etária de 18 a 24 anos até o final de 2010. O PNE preconizou, ainda, a manutenção de alunos nas instituições públicas, em uma proporção de pelo menos 40\%, além da definição de ações direcionadas à inclusão social, visando a formulação de políticas para minorias vítimas de discriminação e alunos carentes, com o objetivo de facilitar o acesso à educação superior, inclusive por meio de "programas de compensação de deficiências de sua formação escolar anterior, permitindo-lhes, desta forma, competir em igualdade de condições nos processos de seleção e admissão a esse nível de ensino" (BRASIL, 2001, p. 36). 
Essas políticas surgem com o intuito de atender a um novo perfil de estudante que busca melhorias na educação superior, frente às dificuldades ao acesso por serem oriundos de escolas públicas - que também sofreram ampliação no decorrer dos anos, mas ainda apresentam inúmeros problemas. O ensino médio público, por exemplo, ainda é caracterizado pela falta de ampliação e desigualdade da cobertura aos estudantes, tanto para os que estão na idade adequada, quanto para o público da Educação de Jovens e Adultos (EJA), possuindo elevadas taxas de reprovação e abandono (MORAES e ALAVARSE, 2011), além da qualidade questionável do ensino ofertado, recebendo poucas propostas de melhoria nesse quadro, até então (MELO e DUARTE, 2011).

Uma das políticas que reconhecidamente favoreceu o acesso ao nível superior, especialmente por estudantes de baixa renda, foi o Fundo de Financiamento Estudantil (Fies), vinculado ao Ministério da Educação e iniciado em $1999^{12}$. Operacionalizado em conjunto pelo Fundo Nacional de Desenvolvimento da Educação (FNDE) e pelos bancos Caixa Econômica Federal (CEF) e Banco do Brasil (BB), o programa visa facilitar o financiamento das mensalidades de cursos de graduação em instituições de ensino superior não gratuitas. Embora criado em 1999, o Fies assumiu protagonismo, principalmente, depois de 2010 (Tabela 1), quando sofreu importantes mudanças ${ }^{13}$, entre elas principalmente a característica de oferecer financiamentos a juros baixos ${ }^{14}$, o que permitiu sua rápida expansão e adesão vertiginosa, tanto de estudantes, como das IES privadas, que amplamente se beneficiaram das condições facilitadas do financiamento federal. Segundo o Relatório de Gestão 2014 do Fies (BRASIL, 2015a, p. 22), havia cerca de 1,9 milhão de contratos formalizados por meio do Fundo no período de 2010-2014, o que representava aproximadamente $35 \%$ dos estudantes matriculados na educação superior, segundo o Censo da Educação Superior de 2013.

\footnotetext{
${ }^{12}$ O Fies substituiu um programa anterior, o Programa de Crédito Educativo (PCE/CREDUC), criado em 1976.

${ }^{13}$ Em 2010, o Fies teve as seguintes alterações: o estudante passou a poder solicitar o financiamento em qualquer período do ano; a taxa de juros foi reduzida para 3,4\% ao ano; o limite máximo de financiamento foi elevado para até $100 \%$ do valor do curso; ocorreu ampliação da carência para 18 meses após a formatura; ampliação do prazo de quitação, que passou a ser de até 3 vezes o período financiado do curso e foi criado o Fundo de Garantia de Operações de Crédito Educativo (FGEDUC), que possibilitou a entrada de novos estudantes sem a necessidade de um fiador.

${ }^{14}$ A partir de 2010, o Fies passou a oferecer o financiamento de mensalidades estudantis a uma taxa de juros de $3,4 \%$ ao ano, percentual considerado baixo, principalmente em relação a outras taxas de juros da economia brasileira. Por exemplo, é possível fazer uma comparação com a Taxa Básica de Juros da economia (Selic), que entre 2010 e 2014 ficou, em média, a 10\% ao ano (BRASIL, 2016b).
} 
Tabela 1 - Número de contratos formalizados do Fundo de Financiamento Estudantil (Fies).

Brasil, 1999-2014.

\begin{tabular}{ccc}
\hline Período & $\begin{array}{c}\text { Contratos Fies } \\
\text { Formalizados } \\
\mathbf{n}^{\mathbf{0}}\end{array}$ & $\begin{array}{c}\text { Variação } \\
\text { anual } \\
\mathbf{\%}\end{array}$ \\
\hline Acumulado 1999-2009 & $\mathbf{6 0 0 . 0 0 0}$ & - \\
\hline $\mathbf{2 0 1 0}$ & 76.000 & - \\
$\mathbf{2 0 1 1}$ & 154.250 & $102,96 \%$ \\
$\mathbf{2 0 1 2}$ & 377.780 & $144,91 \%$ \\
$\mathbf{2 0 1 3}$ & 559.905 & $48,21 \%$ \\
$\mathbf{2 0 1 4}$ & 732.243 & $30,78 \%$ \\
\hline Acumulado 2010-2014 & $\mathbf{1 . 9 0 0 . 1 7 8}$ & - \\
\hline
\end{tabular}

Fonte: BRASIL (2015a).

Elaboração própria.

A Tabela 1, que permite observar de forma mais detalhada os dados do Fies, retrata que durante todo o período compreendido entre 1999 e 2009, o Fies registrou 600 mil contratos formalizados. Em 2010, ano que passou por mudanças em sua operacionalização, registrou 76 mil contratos, passando a apresentar forte ritmo de aumento nos anos seguintes, crescendo mais de 100\% ao ano em 2011 e 2012 (154 mil e 377 mil contratos, respectivamente), até diminuir o ritmo em 2013 e 2014, mas ainda crescendo significativamente - 48\% em 2013 e $31 \%$ em 2014. Portanto, no período entre 2010 a 2014 o Fies registrou 1,9 milhão de contratos formalizados, mais do que o triplo de contratos entre 1999-2009.

\subsubsection{Políticas educacionais de nível superior a partir de 2003: democratização do acesso e expansão do setor público federal}

A mudança governamental ocorrida em 2003, ano em que foi eleito Luiz Inácio Lula da Silva (Lula) para presidente, ocasionou diversas transformações nas políticas educacionais do país. A Coligação Lula Presidente ${ }^{15}$, que incluía seu partido, o Partido dos Trabalhadores (PT), estava referenciada em um programa de governo no qual "as políticas sociais e, especialmente, as políticas educacionais ganhavam destaque, sendo mesmo colocadas no centro do processo de mudanças estruturais requeridas pelo país” (PAULA, 2006, p. 136). Segundo Martins (2009,

\footnotetext{
${ }^{15}$ Composta por: Partido dos Trabalhadores (PT), Partido Liberal (PL), Partido Comunista do Brasil (PCdoB), Partido da Mobilização Nacional (PMN) e Partido Comunista Brasileiro (PCB).
} 
p. 26), buscou-se também a "reorientação da política educacional, no sentido de fortalecer o ensino público, sobretudo nas universidades federais".

Nesse período, foi dada ênfase a uma série de políticas, dentro de um movimento com vistas à democratização do acesso e inclusão de classes sociais tradicionalmente excluídas desse nível educacional (PAULA, 2006; GOMES e MORAES, 2012), com a instituição do Programa Universidade para Todos (ProUni), em 2005, e de políticas de cotas raciais em universidades públicas. Também se destaca a implementação de políticas de expansão e rearranjo das universidades federais, por meio do Programa de Apoio aos Planos de Reestruturação e Expansão das Universidades Federais (Reuni), a partir de 2007; da criação de Institutos Federais de Educação, Ciência e Tecnologia (IFs), a partir de 2008, e do oferecimento de educação a distância via Universidade Aberta do Brasil (UAB) a partir de 2006, todas medidas que caracterizaram maior oferta de acesso ao setor público. Essas mudanças, que serão detalhadas a seguir, também sinalizaram a tentativa de alcançar as metas estabelecidas no PNE 2001-2010, especialmente em relação ao crescimento do acesso às IES (públicas e privadas).

O Programa Universidade para Todos (ProUni), criado em 2004 pela Medida Provisória $\mathrm{n}^{\circ} 213$ e implementado pela Lei $\mathrm{n}^{\mathrm{o}} 11.096$, de 13 de janeiro de 2005, concede bolsas de estudos a estudantes em cursos de graduação em IES privadas (com ou sem fins lucrativos). O Programa resultou em um intenso debate ${ }^{16}$ na educação superior, pois muito além de seu caráter de política de ação afirmativa - pois possui como público alvo estudantes de baixa renda e provenientes de escola pública, além de apresentar reserva de vagas por critérios de cor/raça e etnia -, também caracterizou-se por ser uma política voltada às instituições privadas, atendendo aos interesses de entidades do setor, culminando o incentivo a já desenfreada expansão dessa esfera. Ao participar do ProUni, o Estado concede a isenção de diversos impostos que obrigatoriamente seriam pagos por essas IES, em troca de uma quantidade estipulada de bolsas de estudo. A política ficou marcada, então, pela característica de promover o financiamento do setor privado com recursos públicos, e, concomitantemente, pela falta de incentivo e investimento no setor público de educação superior (PAULA, 2006).

Vale ressaltar que no caso de políticas afirmativas instituídas ${ }^{17}$ como o ProUni, estas também podem ser caracterizadas como medidas compensatórias, ou seja, não possuem poder

${ }^{16}$ O ProUni, enquanto objeto de estudo deste trabalho, será abordado de forma mais aprofundada no Capítulo 2 , dedicado inteiramente ao tema.

${ }^{17}$ Posteriormente, já no governo de Dilma Rousseff (2011-2014), foi aprovada a Lei de Cotas para o Ensino Superior em 2012 (Lei $n^{\circ}$ 12.711). A lei preconiza às universidades e institutos federais a reserva em cada processo seletivo de seus cursos de, no mínimo, $50 \%$ de vagas para alunos que estudaram em escolas públicas (de forma integral), reservando o percentual correspondente ao da soma de pretos, pardos e indígenas no estado 
de solucionar problemas de desigualdade social, que são históricos, assim como não podem substituir outras políticas públicas fundamentais, como investimentos no setor público na educação básica. Por outro lado, conforme consta nas premissas do PNE 2001-2010, algumas políticas são necessárias, no intuito de poder compensar, no curto prazo, as consequências próprias do modelo econômico, que geraram desigualdades socioeconômicas e educacionais. Por outro lado, outro aspecto importante a analisar sobre essas políticas, e tido como fundamental para Paula (2006), é que elas visam, na maior parte dos casos, resolver apenas a questão do acesso, mas a permanência nas instituições não é garantida - em que pesem as despesas com alimentação, transporte, moradia e materiais para acompanhar as aulas.

Com relação à expansão do setor público de educação superior, destacam-se algumas iniciativas: o Programa de Expansão das Instituições Federais de Ensino Superior, instituído em 2003, por meio de um processo de interiorização dos campi das universidades federais; a criação dos Institutos Federais de Educação, Ciência e Tecnologia (IFs) ${ }^{18}$ e do Programa de Apoio aos Planos de Reestruturação e Expansão das Universidades Federais (Reuni). O Reuni foi instituído por meio do Decreto $\mathrm{n}^{\circ}$ 6.096, de 24 de abril de 2007, visando ampliar o acesso e a permanência na educação superior pública, por meio da expansão da rede federal de educação superior, objetivando a expansão de vagas, redução da evasão, aperfeiçoamento da estrutura física e recursos humanos existentes.

Nesse sentido, “deve-se enfatizar que essas e outras iniciativas revelam que a relação governo federal e universidades federais, no Governo Lula, representa uma ruptura com a lógica e o tratamento que se testemunhou durante o Governo FHC" (GOMES e MORAES, 2012, p. 185).

Segundo dados do Relatório da Comissão de Avaliação do Processo de Expansão do Reuni (BRASIL, 2012a), entre 2003 e 2010, ocorreu aumento de 45 para 59 universidades federais. O número de campi universitários cresceu de 148 para 274 no mesmo período, gerando o processo de interiorização das universidades, passando de 114 municípios atendidos para 272.

Os dados dos Censos da Educação Superior no período 2000-2013 (Tabela 2) revelam que as matrículas na rede federal cresceram 135,7\%. Somente no período 2012-2013, a

do processo seletivo, de acordo com o último censo demográfico do Instituto Brasileiro de Geografia e Estatística (IBGE). As políticas de cotas já eram realizadas em algumas universidades públicas, que gozam de autonomia em seus processos seletivos - porém, sem a obrigação de lei.

${ }^{18}$ Os IFs foram criados por meio do Decreto $n^{\circ}$ 6.095/2007, o que compreendeu uma reestruturação de instituições federais técnicas e tecnológicas já existentes. 
expansão de matrículas na rede federal foi de 4,6\%, alcançando uma participação de 58,9\% na rede pública de ensino superior (1,13 milhão de matrículas).

Tabela 2 - Número de matrículas, segundo a categoria administrativa da IES. Brasil, 2000-2013

\begin{tabular}{|c|c|c|c|c|c|c|}
\hline \multirow{2}{*}{ Ano } & \multirow{2}{*}{$\begin{array}{l}\text { Matrículas } \\
\text { Totais }\end{array}$} & \multicolumn{4}{|c|}{ Matrículas Públicas } & \multirow{2}{*}{$\begin{array}{l}\text { Matrículas } \\
\text { Privadas }\end{array}$} \\
\hline & & Total & Federal & Estadual & Municipal & \\
\hline 2000 & 2.694 .245 & 887.026 & 482.750 & 332.104 & 72.172 & 1.807 .219 \\
\hline 2001 & 3.036.113 & 944.584 & 504.797 & 360.537 & 79.250 & 2.091 .529 \\
\hline 2002 & 3.520 .627 & 1.085 .977 & 543.598 & 437.927 & 104.452 & 2.434 .650 \\
\hline 2003 & 3.936 .933 & 1.176 .174 & 583.633 & 465.978 & 126.563 & 2.760 .759 \\
\hline 2004 & 4.223.344 & 1.214 .317 & 592.705 & 489.529 & 132.083 & 3.009 .027 \\
\hline 2005 & 4.567.798 & 1.246 .704 & 595.327 & 514.726 & 136.651 & 3.321 .094 \\
\hline 2006 & 4.883.852 & 1.251 .365 & 607.180 & 502.826 & 141.359 & 3.632 .487 \\
\hline 2007 & 5.250 .147 & 1.335 .177 & 641.094 & 550.089 & 143.994 & 3.914 .970 \\
\hline 2008 & 5.808.017 & 1.552 .953 & 698.319 & 710.175 & 144.459 & 4.255 .064 \\
\hline 2009 & 5.954 .021 & 1.523 .864 & 839.397 & 566.204 & 118.263 & 4.430 .157 \\
\hline 2010 & 6.379.299 & 1.643 .298 & 938.656 & 601.112 & 103.530 & 4.736 .001 \\
\hline 2011 & 6.739 .689 & 1.773 .315 & 1.032 .936 & 619.354 & 121.025 & 4.966 .374 \\
\hline 2012 & 7.037.688 & 1.897 .376 & 1.087 .413 & 625.283 & 184.680 & 5.140 .312 \\
\hline 2013 & 7.305.977 & 1.932 .527 & 1.137 .851 & 604.517 & 190.159 & 5.373 .450 \\
\hline $\begin{array}{c}\text { Variação } \\
\text { 2013/2000 }\end{array}$ & $171,2 \%$ & $117,9 \%$ & $135,7 \%$ & $82,0 \%$ & $163,5 \%$ & $197,3 \%$ \\
\hline
\end{tabular}

Apesar de todas as transformações ocorridas, ainda analisando os dados da Tabela 2, quando se observa o movimento dos últimos anos em torno da estrutura da educação superior brasileira, é evidente que o setor privado continua exercendo participação ainda muito significativa. No período compreendido entre 2000 e 2013, a expansão em termos percentuais das matrículas em IES públicas foi considerável, de 117,9\%, sobretudo por conta da rede federal, conforme apontado anteriormente. Entretanto, as matrículas na rede privada alcançaram o maior crescimento entre as categorias administrativas: 197,3\%, chegando à participação de $73,5 \%$ no total de matrículas.

Analisando o ritmo de crescimento em termos de IES (Gráfico 2), verifica-se, a partir de 2007, uma diminuição no ritmo de crescimento do setor privado da educação superior, comparado às altas taxas apresentadas no início da década de 2000, inclusive apresentando 
decréscimo no número de IES em 2008 (-0,8\%), fato que não ocorria desde o ano de 1997. Em 2011 e 2013 esse número também apresentou quedas, de 0,9\% e 1,0\%. De toda forma, apesar da desaceleração na expansão, as IES privadas em 2013 ainda dominavam 87,4\% do setor.

Gráfico 2 - Número de Instituições de Ensino Superior e variação anual (\%), por categoria administrativa (pública e privada).

Brasil, 2000-2013

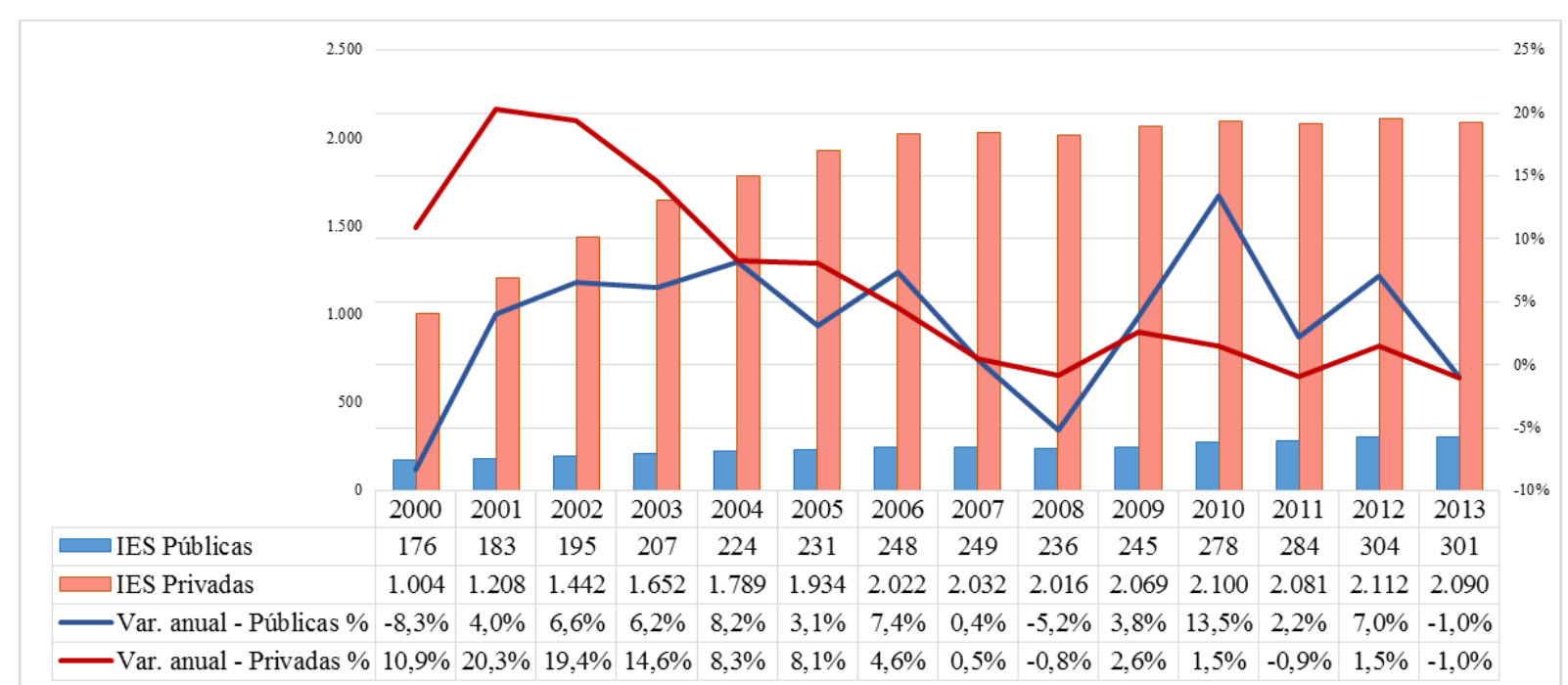

Fonte: INEP - Censos da Educação Superior (BRASIL, 2005b, 2012b, 2015b).

Elaboração própria.

A presença do setor privado na educação superior brasileira é, inclusive, uma das maiores do mundo - em diversos países, é verificada uma situação inversa, de predomínio (ou, pelo menos, mais da metade do setor ocupado) pelo segmento público, tais como: Argentina, Uruguai, Estados Unidos, França, Itália e Canadá (PAULA, 2006). O estudo de Chaves e Amaral (2015) aponta que a privatização desse nível educacional no país é a segunda maior entre 15 países pesquisados da América Latina, somente perdendo para o Chile, cujo setor é inteiramente representado por instituições privadas.

A problemática do predomínio de instituições privadas na educação superior brasileira, e o movimento de inclusão de estudantes majoritariamente nesse segmento, em detrimento de políticas visando o fortalecimento do setor público, é alvo de diversos debates na área. Uma parcela da restrita faixa de pessoas que conseguiram chegar ao nível superior "está matriculada em instituições privadas que oferecem um ensino muito precário, não realizam atividades de pesquisa, nem extensão, nos moldes das universidades públicas” (PAULA, 2006, p. 135). As instituições de perfil empresarial, de acordo com Martins (2009), concentram atividades voltadas para a formação profissional, empregando professores com pouca titulação acadêmica 
e com jornada de trabalho do tipo horista. Também verifica-se constantemente, segundo o autor, a ausência de atividades de pesquisa e pós-graduação stricto sensu.

A dicotomia entre o ensino ofertado em IES públicas e privadas pode ser ilustrada com alguns dados do Censo da Educação Superior 2013 (BRASIL, 2015b): os docentes em exercício, nas IES públicas, possuem jornada de trabalho em tempo integral em 81,6\% dos casos, enquanto que nas IES privadas, predominam as jornadas de tempo parcial $(35,2 \%)$ e horistas $(39,9 \%)$. Com relação à titulação, a quantidade de docentes mestres e doutores é, nas IES públicas, de 82,8\%. Já nas IES privadas, esse percentual chega a 65,3\% (Tabela 3).

Tabela 3. Funções docentes em exercício na educação superior, por categoria administrativa da IES, grau de formação e regime de trabalho.

Brasil, 2003 e 2013

\begin{tabular}{cc|ccc|ccc}
\hline \multirow{2}{*}{ IES / ano } & \multicolumn{3}{|c|}{ Grau de Formação } & \multicolumn{3}{c}{ Regime de Trabalho } \\
\cline { 2 - 7 } & & Especialização & Mestrado & Doutorado & $\begin{array}{c}\text { Tempo } \\
\text { integral }\end{array}$ & $\begin{array}{c}\text { Tempo } \\
\text { parcial }\end{array}$ & Horista \\
\hline \multirow{2}{*}{ IES públicas } & $\mathbf{2 0 0 3}$ & $18,8 \%$ & $27,3 \%$ & $39,5 \%$ & $80,0 \%$ & $19,8 \%$ & $8,2 \%$ \\
\cline { 2 - 7 } & $\mathbf{2 0 1 3}$ & $12,2 \%$ & $29,6 \%$ & $53,2 \%$ & $81,6 \%$ & $11,9 \%$ & $6,5 \%$ \\
\hline \multirow{2}{*}{ IES privadas } & $\mathbf{2 0 0 3}$ & $35,1 \%$ & $39,3 \%$ & $11,8 \%$ & $15,3 \%$ & $27,2 \%$ & $62,1 \%$ \\
\cline { 2 - 8 } & $\mathbf{2 0 1 3}$ & $34,1 \%$ & $47,1 \%$ & $18,2 \%$ & $24,9 \%$ & $35,2 \%$ & $39,9 \%$ \\
\hline
\end{tabular}

Fonte: INEP - Censos da Educação Superior 2003 e 2013 (BRASIL, 2004a, 2015b)

Elaboração própria.

Entretanto, com os dados da Tabela 3, é observado um aumento do nível de titulação na comparação entre 2003 e 2013 nos setores privado e público, sendo que a expansão do setor privado (+14,2\% dos professores com mestrado ou doutorado) está próxima dos patamares do setor público (+16\% na mesma comparação), embora a proporção de docentes com titulação mais elevada continue maior no setor público. Ainda que este seja apenas um aspecto que pode impactar na qualidade do ensino oferecido pelas instituições, é importante ressaltar que “existem diferenças qualitativas entre as instituições públicas e privadas, mas também é possível constatar assimetrias no interior de cada um desses segmentos" (MARTINS, 2009, p. 29). 


\subsubsection{Expansão da Educação a Distância (EaD)}

Outro traço marcante da expansão da educação superior brasileira, especialmente a partir de 2005, é a modalidade de Educação a Distância (EaD). Os cursos EaD vem ganhando força, muito em razão do crescente aumento de novas tecnologias em todos os campos da sociedade e também nos processos educacionais (OLIVEIRA, 2009).

O percentual de matrículas nessa modalidade vem crescendo anualmente (Tabela 4). As matrículas na educação superior, especificamente em cursos $\mathrm{EaD}$, era de apenas 1,3\% em 2005; em 2013, já alcançaram 15,8\% do setor. Além disso, 86,6\% dessas matrículas estão em instituições privadas, embora a expansão dessa modalidade no setor público também tenha sido estimulada depois do advento da Universidade Aberta do Brasil (UAB), que oferta cursos por meio de convênios com universidades públicas federais, uma política instituída pelo Decreto $\mathrm{n}^{\circ}$ 5.800 , de 8 de junho de 2006. A UAB contribuiu também para a interiorização do ensino público de nível superior, papel que antes era realizado por instituições privadas (BARREYRO e COSTA, 2015).

No período de 2000 a 2013 as matrículas EaD públicas cresceram 288,3\% (chegando a 154 mil); já no setor privado, o crescimento foi muito maior, de $9.784,4 \%$, saltando de 10 mil para quase 1 milhão de matrículas.

Tabela 4 - Número de matrículas na educação superior, por modalidade de ensino. Brasil, 2003-2013

\begin{tabular}{cccccc}
\hline Ano & $\begin{array}{c}\text { Total de } \\
\text { Matrículas } \\
\text { ES (a) }\end{array}$ & $\begin{array}{c}\text { Matrículas EaD } \\
\text { (b) }\end{array}$ & $\begin{array}{c}\text { Part. EaD no } \\
\text { total (b/a) }\end{array}$ & $\begin{array}{c}\text { Matrículas } \\
\text { EaD - } \\
\text { Públicas }\end{array}$ & $\begin{array}{c}\text { Matrículas } \\
\text { EaD - } \\
\text { Privadas }\end{array}$ \\
\hline $\mathbf{2 0 0 3}$ & 3.936 .933 & $\mathbf{4 9 . 9 1 1}$ & $1,3 \%$ & $\mathbf{3 9 . 8 0 4}$ & $\mathbf{1 0 . 1 0 7}$ \\
$\mathbf{2 0 0 4}$ & 4.223 .344 & $\mathbf{5 9 . 6 1 1}$ & $1,4 \%$ & $\mathbf{3 5 . 9 8 9}$ & $\mathbf{2 3 . 6 2 2}$ \\
$\mathbf{2 0 0 5}$ & 4.567 .798 & $\mathbf{1 1 4 . 6 4 2}$ & $2,5 \%$ & $\mathbf{5 4 . 5 1 5}$ & $\mathbf{6 0 . 1 2 7}$ \\
$\mathbf{2 0 0 6}$ & 4.883 .852 & $\mathbf{2 0 7 . 2 0 6}$ & $4,2 \%$ & $\mathbf{4 2 . 0 6 1}$ & $\mathbf{1 6 5 . 1 4 5}$ \\
$\mathbf{2 0 0 7}$ & 5.250 .147 & $\mathbf{3 6 9 . 7 6 6}$ & $7,0 \%$ & $\mathbf{9 4 . 2 0 9}$ & $\mathbf{2 7 5 . 5 5 7}$ \\
$\mathbf{2 0 0 8}$ & 5.808 .017 & $\mathbf{7 2 7 . 9 6 1}$ & $12,5 \%$ & $\mathbf{2 7 8 . 9 8 8}$ & $\mathbf{4 4 8 . 9 7 3}$ \\
$\mathbf{2 0 0 9}$ & 5.954 .021 & $\mathbf{8 3 8 . 1 2 5}$ & $14,1 \%$ & $\mathbf{1 7 2 . 6 9 6}$ & $\mathbf{6 6 5 . 4 2 9}$ \\
$\mathbf{2 0 1 0}$ & 6.379 .299 & $\mathbf{9 3 0 . 1 7 9}$ & $14,6 \%$ & $\mathbf{1 8 1 . 6 0 2}$ & $\mathbf{7 4 8 . 5 7 7}$ \\
$\mathbf{2 0 1 1}$ & 6.739 .689 & $\mathbf{9 9 2 . 9 2 7}$ & $14,7 \%$ & $\mathbf{1 7 7 . 9 2 4}$ & $\mathbf{8 1 5 . 0 0 3}$ \\
$\mathbf{2 0 1 2}$ & 7.037 .688 & $\mathbf{1 . 1 1 3 . 8 5 0}$ & $15,8 \%$ & $\mathbf{1 8 1 . 6 2 4}$ & $\mathbf{9 3 2 . 2 2 6}$ \\
$\mathbf{2 0 1 3}$ & 7.305 .977 & $\mathbf{1 . 1 5 3 . 5 7 2}$ & $15,8 \%$ & $\mathbf{1 5 4 . 5 5 3}$ & $\mathbf{9 9 9 . 0 1 9}$ \\
\hline Variação 2013/2003 & $\mathbf{8 5 , 6 \%}$ & $\mathbf{2 . 2 1 1 , 3 \%}$ & - & $\mathbf{2 8 8 , 3 \%}$ & $\mathbf{9 . 7 8 4 , 4 \%}$ \\
\hline
\end{tabular}

Fonte: INEP - Censos da Educação Superior (BRASIL, 2005b, 2012b, 2015b).

Elaboração própria. 
Para Mancebo, Vale e Martins (2015, p. 41), o quadro de expansão dessa modalidade de ensino "decorre, entre outros fatores, da política formulada pelo Estado brasileiro para promover a expansão do ensino superior [...] e da facilidade para credenciar instituições e cursos frente a um marco regulatório pouco consistente para o EaD”. Além disso, para as autoras, a modalidade EaD é marcada por uma expansão indiscriminada, guiada por diretrizes visando a facilitação do acesso ao nível superior para camadas excluídas da sociedade; porém, faltam ainda a essa modalidade de ensino aspectos como: infraestrutura adequada, condições efetivas de aprendizado, e relações de trabalho de docentes menos precarizadas, pois alguns sequer dispõem de vínculo empregatício nesse âmbito (MANCEBO, VALE e MARTINS, 2015).

\subsubsection{Os movimentos de financeirização, oligopolização e internacionalização da Educação Superior}

No período mais recente, especialmente a partir de 2005, é possível identificar, embutido no processo de consolidação das IES do setor privado de educação superior, o reflexo dos rearranjos econômicos da sociedade como um todo: há uma tendência crescente de concentração institucional, em que se perpetuam processos de fusões, aquisições de instituições menores por grandes grupos, criação de redes universitárias e, inclusive, a instituição de fenômenos próprios do mercado capitalista financeiro no campo educacional, ou seja, a presença de fundos de investimento e forte atuação de grupos estrangeiros no Brasil. Essas transformações constituíram-se em um caminho em direção à financeirização, oligopolização e internacionalização do setor (CARVALHO, 2013, p. 761), em que as IES, agora integrantes de grandes grupos educacionais, passaram a atuar em outros países, realizar aquisições por meio de fundos private equity ${ }^{19}$ e abertura de capitais, de forma a negociar ações na Bolsa de Valores (SGUISSARDI, 2008, 2014; MARTINS, 2009; MANCEBO, VALE e MARTINS, 2015). Nesse âmbito, é possível atestar que a educação superior foi bastante influenciada pelos reflexos do próprio modelo econômico no qual está inserida: "as estratégias do movimento de expansão do mercado educacional ancoram-se, em última instância, nos processos de mundialização do capital, com predominância financeira [...]” (SGUISSARDI, 2014, p. 112)

Um dos primeiros movimentos em torno das fusões e aquisições se deu em 2005, momento em que a Universidade Anhembi-Morumbi foi adquirida pelo grupo americano

\footnotetext{
${ }^{19}$ Os private equity são "fundos de investimento em participações de empresas de capital aberto ou fechado, com envolvimento posterior da entidade gestora/investidora nos foros de gestão da entidade investida" (CARVALHO, 2013, p. 770).
} 
Laureate, operação que contou ainda com a participação do Banco Pátria, administrador de fundos de investimento em educação no país, como responsável pela reestruturação organizacional da universidade (OLIVEIRA, 2009).

Ainda segundo levantamento de Oliveira (2009), outro representante internacional, o Internacional Finance Corporation (IFC) investiu doze milhões de dólares para a aquisição de parte do controle do grupo Anhanguera Educacional, por meio de fundo de investimento também administrado pelo Banco Pátria. No ano de 2007, a Anhanguera Educacional lançou ações na Bolsa de Valores de São Paulo, assim como os grupos Estácio de Sá, Kroton Educacional, Grupo Pitágoras, entre outros, processo que se intensificou nos anos seguintes com a aquisição de instituições menores por parte dessas instituições investidoras. Em outubro de 2015, encontravam-se listados no site da BM\&FBOVESPA quatro grupos educacionais: Ser Educacional S.A., Kroton Educacional S.A., Estácio Participações S.A. e GAEC Educação S.A.

Além desses movimentos, é crescente a atividade de consultorias no setor, visando o planejamento estratégico, a reestruturação e o marketing institucional, a maximização de lucros (e racionalização de custos), entre outros objetivos (OLIVEIRA, 2009; SGUISSARDI, 2014).

Um dos mais recentes e significativos movimentos em direção à oligopolização do setor ocorreu em 2014, quando foi anunciada uma fusão entre os grupos Anhanguera e Kroton, estabelecendo o maior grupo privado educacional do Brasil e maior empresa educacional do mundo, denominada Kroton Educacional (SGUISSARDI, 2014), que detém as IES Anhanguera, Fama, Pitágoras, Uniasselvi, Unic, Unime e Unopar, reunindo uma base de 1,07 milhões de alunos de educação superior em todo o Brasil (KROTON, 2015). A concentração institucional $^{20}$, portanto, se tornou uma marca no segmento de educação superior privada.

O número de operações, fusões e aquisições destaca-se tanto pela frequência no setor, quanto pelo montante investido. Somente cinco operações desse tipo, entre diferentes instituições e ocorridas entre 2012 e 2014, reuniram valor de negócio estimado em R\$4,18 bilhões, de acordo com dados da CM Consultoria (2014). Ainda segundo o mesmo levantamento, somente no setor de educação superior foram realizadas 56 operações entre 2008 e 2009, 12 em 2010, 22 em 2011, 15 em 2012 e 16 em 2013.

O estudo de Sarfati e Shwartzbaum (2013), analisando as fusões e aquisições de grupos educacionais como Anhanguera, Kroton e Estácio no período de 2008 a 2012, atesta que o

\footnotetext{
${ }^{20} \mathrm{Na}$ educação superior brasileira é possível notar que poucas IES, geralmente ligadas aos grandes grupos educacionais, concentram a maior parte das matrículas. De acordo com o levantamento de Sguissardi (2014), no ano de 2013, os 12 maiores grupos educacionais com fins lucrativos detinham cerca de $40 \%$ do total de matrículas no segmento.
} 
aumento das receitas líquidas dessas empresas (que, no caso da Kroton, por exemplo, quadruplicaram no período mencionado) alcançou patamares que dificilmente seriam alcançados somente por meio de crescimento orgânico ${ }^{21}$.

A facilidade de expansão do mercado educacional, nacional e internacionalmente é, entre outros fatores, estimulada pela

[...] liberdade de atuação de capitais nacionais e estrangeiros permitida pela legislação hoje em vigor, e por outro, a ausência de qualquer limite à participação estrangeira nas mantenedoras ou empresas educacionais. $O$ único limite, de 30\% na participação estrangeira em empresas nacionais de ensino superior, não passa de uma proposta incorporada ao Projeto de Lei de Reforma Universitária que tramita no Congresso Nacional sem a menor previsão de aprovação (SGUISSARDI, 2008, p. 1007).

O Projeto, que atualmente (ano de 2016) continua em tramitação, conforme Sguissardi previa, poderia nessa proposta trazer limites à financeirização da educação superior no Brasil.

Essas transformações recentes que geraram intenso crescimento do setor privado são avaliadas, segundo analistas de mercado, como um processo que possui estreitas relações com a concessão de auxílios de programas governamentais, como o Fies e o ProUni (SÉCCA e LEAL, 2009). Cerca de $40 \%$ dos alunos de educação superior aderiram a um desses programas no ano de 2014 (AQUINO, 2014).

Entretanto, algumas mudanças nas políticas governamentais começam a impactar o quadro de efervescência do setor privado. O Brasil, após apresentar cenários positivos de crescimento econômico desde 2010, vem passando por um momento de crise, de forma mais acentuada desde o final de $2014^{22}$, o que trouxe como consequência a diminuição de investimentos em diversos setores. Paralelamente a isso, como resultado de pacotes de ajustes fiscais do Governo em busca de maior arrecadação, com vistas à superação da crise, ocorreram cortes orçamentários e modificações em diversos programas governamentais, dentre eles o Fies $^{23}$, o que tende a impactar de forma significativa o setor privado de educação superior.

\footnotetext{
${ }^{21}$ Crescimento baseado na geração própria de recursos (SARFATI e SHWARTZBAUM, 2013).

22 Tomando como referência o Produto Interno Bruto (PIB), que após registrar taxas positivas desde 2010, apresentou praticamente estabilidade em $2014(0,1 \%)$ e em 2015 possui crescimento projetado negativo $(-3,7 \%)$ segundo estimativas do Banco Central do Brasil (BCB), quadro que configura crise econômica, em conjunto com outros indicadores como alta inflacionária, aumento da taxa de desemprego e queda da massa salarial (BRASIL, 2015c; DIEESE, 2015).

${ }^{23}$ Em 2015, por meio da Portaria Normativa MEC no 13, foram estabelecidos novos critérios para o Fies: nota mínima no ENEM a ser alcançada pelo estudante, além de não tirar zero na redação; novos critérios de qualidade para os cursos com vagas autorizadas, com base no SINAES; a taxa de juros subiu para 6,5\% ao ano para os novos contratos, além destes terem sido limitados tanto em quantidade, quanto no prazo de solicitação; definição
} 
Os reflexos do corte governamental já são sentidos, em que o número de matrículas nos processos seletivos em IES privadas para o segundo semestre de 2015 caiu $30 \%$ em relação ao mesmo período de 2014 (KOIKE, 2015). No maior grupo, o Kroton Educacional, em que 58\% dos alunos de graduação presencial e $24 \%$ dos alunos de todas as modalidades de graduação possuem o financiamento do Fundo, o relatório de resultados financeiros e operacionais do segundo trimestre de 2015 aponta como cenário e perspectivas "novos produtos para mitigar impactos do Fies mais restritivo" (KROTON, 2015, p. 6), incluindo a oferta de financiamentos privados da própria empresa.

\subsubsection{Desafios da democratização do acesso à educação superior}

Embora inserida em um contexto de problematização entre as relações dos setores público e privado, a educação superior vem expandindo sua participação na população brasileira nos últimos anos, sobretudo pela instituição de políticas que facilitaram o acesso a esse nível educacional: Fies e ProUni, além da expansão do setor público, com a interiorização de Universidades e Institutos Federais. Contudo, a democratização desse nível educacional deve ainda ser objeto de extensa discussão, já que boa parte da população ainda não consegue acessálo.

De acordo com dados da Pesquisa Nacional por Amostra de Domicílios (PNAD), do Instituto Brasileiro de Geografia e Estatística (IBGE), apenas 16,5\% dos estudantes de 18 a 24 anos (considerada a faixa etária ideal, correspondendo à taxa de matrícula líquida) estavam cursando a educação superior em 2013, percentual muito abaixo das metas estabelecidas no Plano Nacional de Educação 2001-2010 - verifica-se que apenas metade da meta de 30\% de taxa de matrícula líquida foi alcançada. Com relação à taxa bruta de matrículas (ou seja, todas as pessoas que frequentam a educação superior, independentemente da idade), verifica-se que chegou a 32,3\% em 2013, entretanto também muito aquém da taxa bruta estabelecida pelo PNE, que era de $50 \%$.

Apesar disso, é importante observar (Gráfico 3), enquanto cenário positivo para o país, o crescimento desses indicadores ao longo dos últimos anos, tanto em termos brutos, como líquidos. No período de 2003 a 2013, a taxa bruta cresceu 12,1 p.p., e a taxa líquida, 5,5 p.p.

de regiões brasileiras prioritárias e áreas de formação (Norte, Nordeste e Centro-Oeste, excluindo Distrito Federal, e carreiras de engenharia, áreas da saúde e formação de professores). (BRASIL, 2015d) 
Gráfico 3 - Taxas de matrícula bruta e líquida na educação superior (em \%).

Brasil, 2003 a 2013.

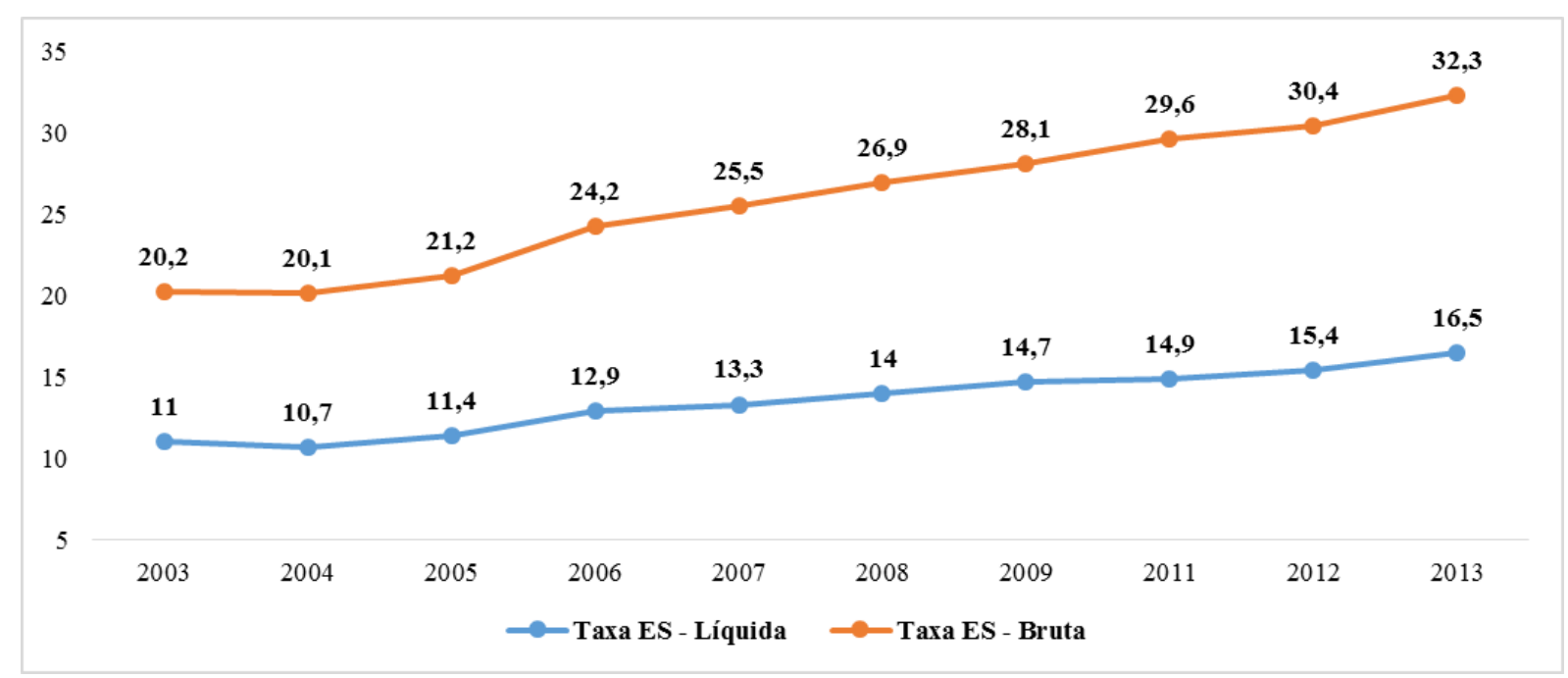

Fonte: OBSERVATÓRIO DO PNE, 2015; IBGE, 2015.

Elaboração própria.

Nota: taxa de matrícula bruta: $\mathrm{n}^{\circ}$ de pessoas que frequentam educação superior, independente da faixa etária população de 18 a 24 anos; taxa matrícula líquida: $\mathrm{n}^{\circ}$ de pessoas que frequentam educação superior de 18 a 24 anos / população de 18 a 24 anos.

Segundo Mont'Alvão Neto (2014) houve avanço visível em relação à participação de estudantes de 18 a 24 anos nesse nível educacional, especialmente a partir dos anos 2000, já que entre as décadas de 1980 e 1990 o percentual, próximo de 4,7\%, não se alterou.

Se tomarmos como parâmetro o estudo de Gomes e Moraes (2012), com base nas ideias de Trow (2005), pode-se considerar a universalização desse nível quando se alcança uma taxa de $50 \%$ ou mais de jovens da população estudantil matriculados; sistema de massa quando essa taxa corresponde de $16 \%$ a $50 \%$ em relação aos jovens de 18 a 24 anos; e sistema de elite, quando as taxas correspondem até $15 \%$. De acordo com o estudo, pode-se dizer que foi vencida a elitização do setor há alguns anos, localizando-se no cerne de um sistema de massa, em razão dos percentuais de matrículas brutas ${ }^{24}$ que superaram 15\% a partir de 2002 (GOMES e MORAES, 2012; CHAVES e AMARAL, 2015).

Acrescenta-se a esses indicadores o fato de que ainda persistem as desigualdades no acesso em relação aos critérios de raça/cor, etnia, fatores socioeconômicos como classe social, renda e educação dos indivíduos, e também entre as diversas regiões do país (CORBUCCI, 2014; BARREYRO e COSTA, 2015).

\footnotetext{
${ }^{24}$ O estudo de Gomes e Moraes (2012) considera a taxa de matrícula bruta para a classificação entre sistemas de elite, massa e universal.
} 
De fato, as questões de desigualdade do acesso das diversas instâncias da sociedade por parte da população recortada por renda e raça/cor/etnia (incluindo o acesso à educação de nível superior) continuam latentes na sociedade brasileira - que, apesar do país ter experimentado um período recente de melhoria socioeconômica ${ }^{25}$ da população, ainda não foram eliminadas.

Dados alarmantes sobre a taxa líquida de matrículas na educação superior em 2013 mostram que, enquanto essa taxa é de $23,6 \%$ para a população branca, para pretos está em $10,2 \%$, e pardos, $11,2 \%$. Esse nível educacional, na mesma comparação, chegou a apenas 5,1\% da parcela dos $25 \%$ mais pobres na sociedade brasileira, ao passo que para os $25 \%$ mais ricos, encontra-se uma taxa de 39\% de escolarização (OBSERVATÓRIO DO PNE, 2015). Chaves e Amaral (2015) apontam que ainda persistem dificuldades para as famílias brasileiras pagarem por esse nível educacional, que é um campo majoritariamente privado. A desigualdade de acesso regional também é uma questão importante. Enquanto a taxa líquida de matrículas na educação superior é de 16,5\% no Brasil, essa taxa pode variar de 22,5\% na região Centro-Oeste e 21,2\% na região Sul, até $12,6 \%$ no Norte e 12,4\% no Nordeste (OBSERVATÓRIO DO PNE, 2015).

Permanece um cenário desafiador no âmbito da aprovação do novo Plano Nacional de Educação (PNE) para o período 2014-2024 (Lei n ${ }^{\circ}$ 13.005, de 25 de junho de 2014), que apresenta 20 metas a serem cumpridas até 2024, sendo que algumas delas estabelecem objetivos historicamente demandados pelos setores educacionais brasileiros, como a meta 20, sobre financiamento, que estabelece o investimento público de 10\% do PIB para esse setor como um todo. A meta 12, sobre educação superior, continua a estabelecer a elevação da taxa bruta de matrícula na educação superior para $50 \%$ e a taxa líquida para $33 \%$, buscando manter a oferta em pelo menos $40 \%$ das matrículas no segmento público.

O baixo investimento público em políticas educacionais é uma constante no cenário brasileiro, que em 2013 representou apenas 6,2\% do PIB (Gráfico 4). Considerando apenas o segmento de educação superior, o montante do PIB investido é ainda menor, embora tenha sofrido ligeiro aumento nos últimos anos, passando de 0,9\% em 2000 para 1,1\% em 2013. Vale ressaltar que esses valores são para os investimentos totais, ou seja, diretos e indiretos ${ }^{26}$. Se

\footnotetext{
${ }^{25}$ O Brasil, especialmente a partir da primeira metade da década de 2000, passou um processo de ligeira redução da desigualdade social, constatada por indicadores como expansão da renda per capita e redução da desigualdade pessoal da renda; redução das taxas de desemprego e de pobreza a níveis históricos; aumento do valor real do salário mínimo, da ocupação e de anos de escolaridade dos brasileiros (POCHMANN, 2010). Para o autor, essas mudanças foram desencadeadas por transformações na economia e em políticas públicas, aliadas ao aumento de investimentos, fortalecimento da indústria e ampliação do mercado interno de consumo.

${ }^{26}$ Segundo a fonte dos dados utilizados, o INEP (BRASIL, 2016c) os investimentos totais consolidados em educação do Governo Federal, dos Estados e do Distrito Federal e dos Municípios são calculados a partir dos
} 
considerarmos apenas os investimentos diretos, o percentual é menor e pouco se alterou com o passar dos anos (de 0,7\% em 2000 para 0,8\% em 2013).

Gráfico 4 - Estimativa do Investimento Público Total e Investimento Público Direto em Educação, em relação ao Produto Interno Bruto (PIB), por nível educacional (em \%)

Brasil, 2000 a 2013

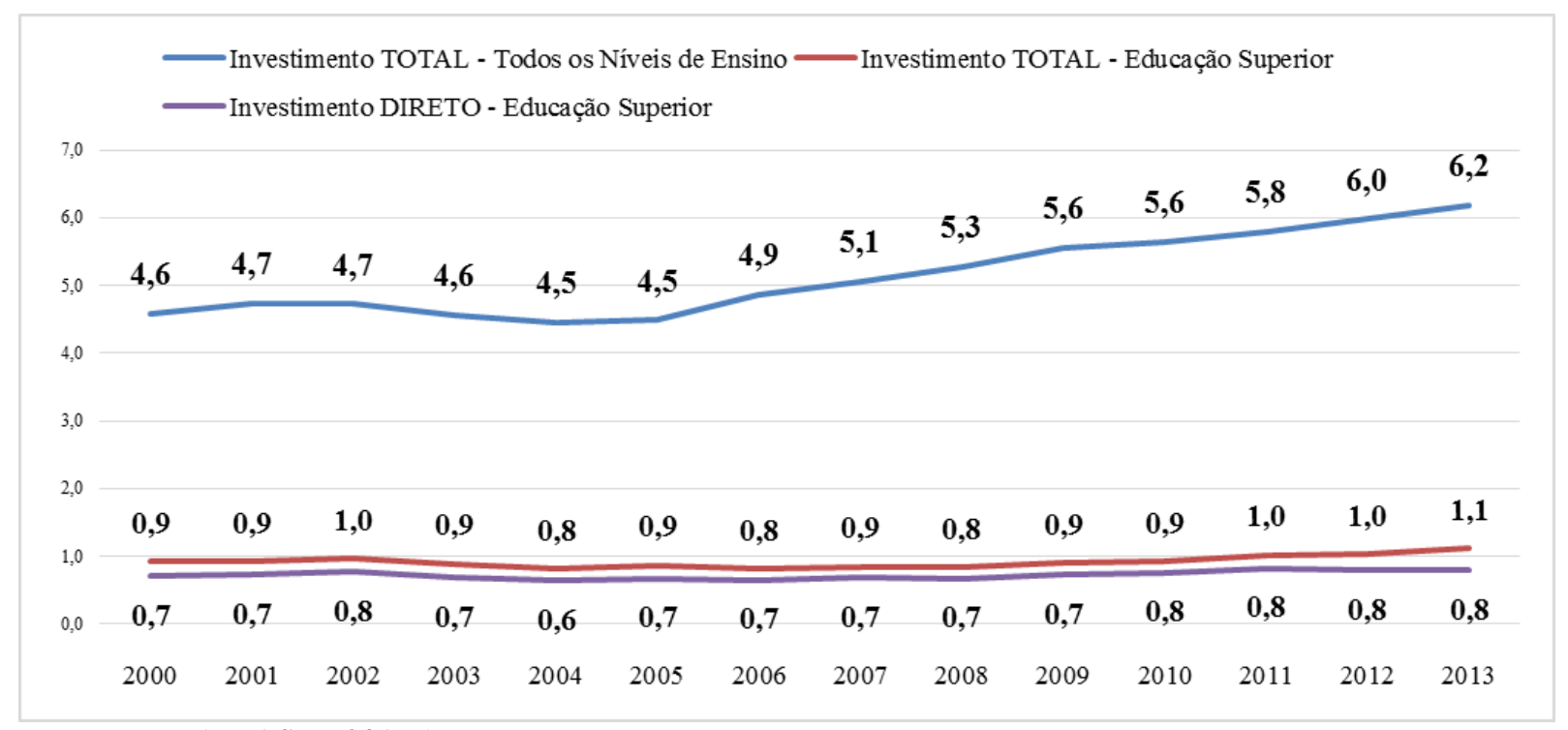

Fonte: INEP (BRASIL, 2016c).

Elaboração própria.

Dias Sobrinho (2013) afirma que a expansão até então observada na educação superior possui um lado bastante positivo, que visa diminuir as desigualdades de acesso a esse nível educacional, e que gera inclusão social de parcelas da sociedade tradicionalmente excluídas. Entretanto, "não há só ganhos na ampliação da educação superior, embora os aspectos positivos superem em muito os negativos" (DIAS SOBRINHO, 2013, p. 117). Para o autor, há limites no fenômeno de democratização do acesso, já que a oferta é apenas uma etapa, sendo a qualidade (entendida enquanto qualidade da formação e dos conhecimentos, ou seja, que contribua com a evolução cultural e social dos sujeitos) um outro patamar essencial ainda a ser alcançado. Além

\footnotetext{
grupos de Natureza de Despesa: Pessoal Ativo e Encargos Sociais (inclusive, a estimativa para complemento da aposentadoria futura do pessoal ativo), outras Despesas Correntes, Investimentos e Inversões Financeiras; estão computados os recursos para bolsa de estudo, financiamento estudantil e a modalidade de aplicação: Transferências Correntes e de Capital ao Setor Privado; não se incluem as despesas com aposentadorias e reformas, pensões, juros e encargos da dívida, e amortizações da dívida da área educacional. A Educação Superior corresponde aos cursos superiores em Tecnologia, demais cursos de Graduação (Presencial e a distância) (exceto cursos sequenciais) e cursos de pós-graduação Stricto Sensu - Mestrado, Mestrado Profissional e Doutorado (excetuando-se as especializações Lato Sensu). Para o cálculo dos investimentos diretos em educação, não se incluem as despesas com aposentadorias e reformas, pensões, recursos para bolsa de estudo e financiamento estudantil, despesas com juros e encargos da dívida e amortizações da dívida da área educacional e a modalidade de aplicação: Transferências Correntes e de Capital ao Setor Privado.
} 
disso, não basta apenas oferecer acesso, pois ainda são enfrentados obstáculos frutos da profunda desigualdade social entre a população de estudantes que ingressa no nível superior, o que gera dificuldades, por exemplo, na permanência e na conciliação do curso com as atividades profissionais:

Do ponto de vista dos estudantes, muitas são as dificuldades. Para alcançar alguma mobilidade social ascendente por meio da educação, os jovens com maiores carências econômicas e sociais, geralmente os primeiros da família a chegar a um curso superior, precisam esforçar-se muito para superar a quantidade e a qualidade dos conhecimentos escolares adquiridos por seus pais. Caso contrário, não conseguirão competir com os jovens mais ricos nas duras disputas por empregos que sejam compatíveis com seus estudos e com suas aspirações. As dificuldades são maiores em países pobres e em vias de desenvolvimento. Eles estão desenvolvendo várias estratégias para aumentar o acesso, mas ainda não alcançaram satisfatoriamente os objetivos de plena cobertura, qualidade e igualdade [...] (DIAS SOBRINHO, 2013, p. 118)

Da fala do autor, é possível identificar como é extremamente importante o esforço de ampliação do acesso à educação superior, e que políticas envolvendo esse objetivo devem ser fortalecidas. No entanto, por estarem focadas a promover um acesso a qualquer educação, e não necessariamente uma educação de qualidade, tais políticas não foram capazes, ainda, de conseguir superar as mazelas educacionais da sociedade brasileira. Por outro lado, considerando a grande desigualdade social ${ }^{27}$ existente, é importante ressaltar que essa questão extrapola o campo educacional, exigindo também mudanças políticas, econômicas e sociais.

Santos (2011, p. 72) alerta a respeito da dimensão e complexidade do problema da democratização do acesso ao ensino superior versus o sistema meritocrático, sendo necessária uma "avaliação crítica do acesso e, portanto, dos obstáculos ao acesso". A democratização do acesso, seja por qualquer perspectiva, deve proporcionar uma reflexão acerca do todo nos espaços universitários, estes que historicamente legitimaram a exclusão social de diversos grupos com a forte elitização que sofreram. Para Martins (2009) é importante a retomada de um projeto de reforma universitária, que construa novos pactos acadêmicos entre os diversos atores do campo educacional, além de ser necessária a reflexão sobre os limites do setor privado versus a visão da educação enquanto um bem público.

A perspectiva da educação enquanto bem público é enfatizada por Dias Sobrinho (2013, p. 109), ao defender que "a educação é um bem público e direito social, pois tem como

\footnotetext{
${ }^{27}$ O Brasil, em termos de desenvolvimento social, medido pelo Índice de Desenvolvimento Humano (IDH), ainda permanece em posição de desvantagem em relação ao cenário global: $79^{\circ}$ país entre 187 países do ranking do Programa das Nações Unidas para o Desenvolvimento (PNUD, 2014).
} 
finalidade essencial a formação de sujeitos e, por consequência, o aprofundamento da cidadania e da democratização da sociedade". Nesse sentido, é possível que formação cidadã e capacitação profissional caminhem juntas, constituindo o sujeito social. Estes aspectos promovem o fortalecimento e desenvolvimento econômico de um país; no entanto, a educação "não pode reduzir-se a serviço do mercado e tampouco a democratização há de se limitar a expandir quantitativamente a escolarização tão somente para impulsionar o desenvolvimento econômico" (DIAS SOBRINHO, 2013, p. 108-109). Para o autor, o desenvolvimento da economia de um país pressupõe a necessidade da educação; porém, a educação não deve possuir o desenvolvimento da economia como finalidade única.

Face aos movimentos de expansão e associação da educação superior privada nas últimas décadas, o autor chama a atenção para a discussão conceitual, dado que os sistemas de educação superior estão cada vez mais privatizados, assim como a formação e o conhecimento atribuído a estes estudantes pode estar também em crescente processo de mercadorização. Entretanto, ressalta que estes são conceitos diferentes:

[...] cumpre alertar que mercadorização e privatização não são necessária e extremamente a mesma coisa. Condenável é a mercadorização da educação, isto é, a transformação da educação, assim como de muitas outras atividades humanas, em meros produtos comerciais, commodities sujeitas às leis e normas dos mercados. Instituições educativas privadas, nos termos amparados e exigidos pela Constituição nacional, são legítimas e necessárias, desde que, sob a autoridade superior do Estado, cumpram com qualidade os objetivos públicos que são essência da educação (DIAS SOBRINHO, 2013, p. 110).

Porém, para o mesmo autor, não há esse compromisso por muitas instituições privadas no país. Embora instituições oriundas do setor privado não sejam uma novidade no país, um movimento de um novo tipo de instituição privada, "com objetivos explícitos de mercado" (DIAS SOBRINHO, 2013, p. 112), conforme assinalamentos anteriormente, vem se acentuando desde o advento das políticas neoliberais, a atuação de organismos multilaterais e as diversas estratégias de reforma da educação superior no país, o que diminuiu a responsabilidade do Estado em investir na educação do setor público e fomentou a expansão de empresas educacionais privadas de caráter estritamente - ou com ênfase - no caráter mercantil.

Essa profunda transformação no sistema de educação superior brasileiro gerou caminhos que levaram à formação e à construção de conhecimentos para atender os interesses do capital econômico e da acumulação financeira. Nestes casos, para Dias Sobrinho (2013), a educação é vista como mercadoria, e não como bem público; assim como o estudante é visto, 
muitas vezes, como um consumidor de um produto, e não um cidadão em busca de conhecimento, autonomia e consciência. Na mesma linha crítica, Mancebo, Vale e Martins (2015) postulam que

Se, por um lado, a expansão engendrada nas últimas décadas pode ser percebida como positiva por ampliar o acesso da população ao ensino superior, deve-se atentar para alguns efeitos perversos do mesmo processo, particularmente no que tange ao perfil dos cursos e das carreiras criados pelas instituições privadas, cuja expansão se dá sob a influência direta de demandas mercadológicas, valendo-se dos interesses da burguesia desse setor em ampliar a valorização de seu capital com a venda de serviços educacionais (MANCEBO, VALE e MARTINS, 2015, p. 33).

Em síntese, conforme definiu Rossato (2006, p. 106), a educação superior no Brasil sempre perpassou por problemas de escolha dicotômicos como "público-privado, ensinopesquisa, qualidade-quantidade" ao longo de sua história, em que muitas questões devem continuar sendo objeto de discussão, mesmo que pareçam já consolidadas.

Por falar em quantidade-qualidade, questões que estão em foco neste trabalho, na próxima seção será discutido o histórico da avaliação da educação superior no Brasil, um dos capítulos mais recentes das transformações que o setor passa desde sua origem: os primeiros debates sobre o assunto datam dos anos 1980, momento em que a expansão de IES e matrículas começou a se intensificar no país.

\subsection{Histórico da Avaliação da Educação Superior no Brasil}

A história da avaliação da educação superior no Brasil é marcada por diversos debates, principalmente em torno da própria concepção de avaliação a ser empregada, e sobre que instância deve ser responsável por realizá-la. Esta é uma discussão diversificada e que envolve os interesses de grupos e de atores políticos, econômicos e sociais distintos que dela participam.

Com relação à concepção de avaliação, entram em discussão as próprias noções de educação pensadas no decorrer do processo (principalmente na polarização da educação como um bem público ou como um segmento do mercado - e, portanto, comercializável). Também compõem o debate as diferentes concepções acerca do que deve ser considerado como indicador de qualidade da educação superior; aliás, o próprio tema da qualidade ${ }^{28}$, que é amplamente

\footnotetext{
${ }^{28} \mathrm{O}$ tema da qualidade da educação superior será discutido mais aprofundada na seção 1.4 deste Capítulo.
} 
utilizado e mencionado na formulação de políticas, é conhecido por não constituir consensos no campo educacional (DIAS SOBRINHO, 2008a).

No debate sobre avaliação ocorrido no país, que se iniciou em meados dos anos 1980, há dois conceitos envolvidos: a ideia de controle/regulação, ou seja, a avaliação para controlar o serviço prestado pelas instituições de ensino superior, com procedimentos burocráticoformais, de forma a atrelar-se ao seu financiamento e estimular sua competitividade via Estado e/ou mercado; ou a ideia de formação/emancipação, que envolve a avaliação para promover o autoconhecimento institucional, fortalecer a autonomia acadêmica e oferecer subsídios para melhorar os processos educacionais (BARREYRO e ROTHEN, 2006; 2011). Com relação à questão de quem, ou qual instância deve realizar essas avaliações, têm-se de um lado a proposta do controle interno pelas próprias instituições, e de outro, o controle de fora, ou seja, pelas agências reguladoras do Estado ou independentes.

A função controladora de avaliação geralmente é delegada a agentes externos, enquanto que a função emancipadora (ou formativa) de avaliação é delegada ao próprio corpo acadêmico, no interior das IES. Esses processos e suas relações, entretanto, não são demarcadamente claros:

[...] as oposições controle/formação e avaliação interna/externa, bem como as vinculações controle/avaliação externa e formação/avaliação interna não são rígidas: é possível que uma avaliação com visão de controle ajude na formação de instituições de ensino superior (IES), que a avaliação interna estabeleça diálogo com a externa e, que a avaliação interna tenha a função de controlar (por exemplo, nas avaliações que têm o objetivo de elaborar o ranking dos professores) (BARREYRO e ROTHEN, 2011, p. 76)

Segundo os autores, há um debate crescente em torno de métodos de avaliação para a educação superior. A década de 1980 é apontada como o período histórico em que as discussões sobre avaliação começaram a ser desenhadas na agenda brasileira (OLIVEIRA et al., 2013), sendo um dos marcos importantes, nesse sentido, o debate que surgiu em torno de duas propostas de avaliação: o Programa de Avaliação da Reforma Universitária (Paru), que data de 1983, e as propostas da Comissão Nacional de Reformulação do Ensino Superior (CNRES) / Grupo Executivo para a Reformulação da Educação Superior (GERES), de 1985 e 1986.

O Paru tinha como objetivo avaliar os resultados da Reforma Universitária de 1968, tentando construir um diagnóstico da situação da educação superior brasileira por meio de indicadores e estudos de caso. Em termos de execução, possuía uma dimensão de avaliação de caráter formativo, em que cada IES realizava a avaliação em seu interior. Porém, a proposta não foi levada adiante e o Paru foi desativado (BARREYRO e ROTHEN, 2008). 
Em 1985, de acordo com Barreyro e Rothen (2011), surgia a Comissão Nacional de Reformulação do Ensino Superior (CNRES), em que 24 membros, entre comunidade acadêmica e sociedade defenderam, entre outras propostas de reformulação de políticas para a educação superior, a avaliação no aspecto de controle, servindo como um instrumento de subsídio para a regulação do sistema, com a realização desta por agentes externos e indicadores de desempenho.

As propostas do CNRES, que necessitavam de operacionalização, desembocaram na criação do Grupo Executivo para a Reformulação da Educação Superior (GERES) pelo MEC em 1986, cuja proposta era de vincular os processos avaliativos à regulação, em que os resultados seriam atrelados diretamente ao financiamento das instituições de ensino. No entanto, por ser um momento de diversos embates políticos no plano educacional, a proposta do projeto de lei do GERES não foi encaminhada ao Congresso Nacional.

Embora nenhuma política tenha sido concretizada nesse período, para Barreyro e Rothen (2011, p. 77), neste momento “já se detectam as duas concepções de avaliação que nortearam as políticas para esse nível de ensino nas décadas seguintes”, em que se encontram em disputa também duas concepções distintas de educação superior: "uma defende o modelo de universidade da Reforma de 68 (a universidade de ensino e pesquisa) e a outra o questiona, propondo a diversificação de formatos institucionais".

Já no início da década de 1990, mais precisamente em 1993, ocorreu a implantação do Programa de Avaliação Institucional da Universidade Brasileira (PAIUB), considerado "a primeira tentativa de implantação de um sistema nacional de avaliação institucional da educação superior no país” (POLIDORI, MARINHO-ARAÚJO e BARREYRO, 2006, p. 427).

Com o PAIUB, inicia-se o processo da avaliação enquanto política pública de educação superior - ainda que no momento atrelado às universidades federais, que iniciaram experiências de autoavaliação institucional nos anos anteriores (POLIDORI, MARINHO-ARAÚJO e BARREYRO, 2006).

O PAIUB preconizava a prestação de contas das atividades da universidade como um princípio ético a ser realizado por elas, visando a melhoria institucional e dos processos educacionais, além de fortalecer a autonomia universitária. Destaca-se que a proposta do PAIUB, embora buscando contemplar a graduação, pós-graduação e extensão, enfatizou a avaliação dos cursos de graduação (POLIDORI, MARINHO-ARAÚJO e BARREYRO, 2006). A noção de avaliação aqui empregada pode ser considerada como a formativa/emancipatória 
(Barreyro e Rothen, 2006, 2011), com a inclusão de elementos de autoavaliação institucional, ou seja, no interior da universidade e com a participação direta da comunidade acadêmica.

No entanto, conforme contextualizado na primeira seção deste Capítulo, as políticas educacionais sofreram grandes mudanças com a transição para os governos de Fernando Henrique Cardoso (FHC), de 1995 a 2002. Nesse período, diversas transformações econômicas e políticas em relação ao Estado ocorreram por meio de algumas medidas como: forte entrada da iniciativa privada, inclusive com a privatização de diversas empresas estatais; introdução da ideia do Estado como ineficiente para implantar políticas públicas e a consequente diminuição drástica de sua atuação, dando ênfase na sua capacidade de atuar como regulador, entre outros. Nesse âmbito, o PAIUB acabou perdendo força e logo foi substituído por outra política de avaliação, o Exame Nacional de Cursos (ENC), ou como ficou mais conhecido, o Provão.

Criado pela Lei ${ }^{\circ}$ 9.131, de 24 de novembro de 1995, o Provão surgiu no momento em que "os exames gerais ganharam importância como instrumento de controle e de reforma [...] os exames nacionais atendem bem as finalidades de medir a eficiência e a eficácia da educação segundo os critérios e as necessidades dos Estados neoliberais [...]” (DIAS SOBRINHO, 2010, p. 202). A política relacionada a esse exame ficou marcada pelos atos normativos que a implementaram, ignorando a maior parte da experiência anterior de discussão de processos de avaliação entre a comunidade acadêmica e o movimento estudantil.

O Provão consistia na realização de um exame anual, em todo o território nacional, aplicado aos concluintes dos cursos de graduação selecionados, e passou a ser considerado instrumento obrigatório para as avaliações realizadas pelo MEC. A Lei nº 9.131/1995 também implantou o Conselho Nacional de Educação (CNE), órgão de assessoramento do Ministério da Educação, que entre outras atribuições relativas à educação de todos os níveis, “definiu a realização do ENC como pré-requisito à obtenção do diploma pelo aluno, bem como a inclusão gradativa de áreas no rol de cursos de graduação a serem avaliados" (OLIVEIRA et al., 2013, p. 637).

O contexto de atividade do Provão, que foi implantado em 1996 e funcionou até 2003, ficou marcado pela forte expansão da educação superior pela via da iniciativa privada (BARREYRO e ROTHEN, 2011). Essa expansão foi favorecida principalmente quando da elaboração da LDB de 1996, devido à abertura para novos modelos institucionais alinhados ideologicamente com a orientação política e econômica da época. Nesse âmbito, ocorreu flexibilização para a criação de novos cursos e para a diversificação de formatos institucionais, bem como a reformulação das grades curriculares. 
Além disso, conforme mencionado, a reconfiguração da educação superior brasileira se deu de forma mais proeminente após a LDB, quando foram admitas empresas com fins lucrativos como mantenedoras de IES, fato que não era legalmente possível até então (muito embora, nesse período, boa parte das fundações que mantinham IES eram empresas privadas). Nesse contexto de expansão e diversificação, o Provão atuou de forma estratégica:

A avaliação da educação superior, mais explicitamente, o ENC cumpriu função primordial nessa política, pois, por um lado, ele foi um instrumento de monitoramento da expansão via iniciativa privada, com o objetivo expresso de controlar a qualidade do ensino oferecido, e por outro, estimulou a concorrência entre as instituições (BARREYRO e ROTHEN, 2011, p. 81).

Durante sua atividade, o Provão se tornou um instrumento amplamente divulgado pela mídia, se tornando uma forte ferramenta de competição e estímulo mercadológico entre as IES, por meio da emissão de conceitos e da introdução dos ranqueamentos, que eram possíveis de serem realizados por meio dos resultados da prova - o que era aceitável como mecanismo estratégico para elevar a qualidade do ensino ofertado. Os conceitos do Provão eram emitidos de forma bastante simplificada, sendo denominados de A a E, do melhor para o pior, respectivamente (ROTHEN e BARREYRO, 2011).

Portanto, utilizando-se destes mecanismos de ranqueamento e grande repercussão midiática, o Provão foi uma medida, entre as reformas estabelecidas no Governo FHC, que atendia a orientação política e econômica inspirada nos preceitos neoliberais. Naquele contexto, o Estado era considerado ineficiente para a oferta da educação superior, e por isso, havia a defesa em direcionar a tarefa ao setor privado. Com relação a esse período, Dias Sobrinho (2008a) afirma que

[...] em um contexto de explosão quantitativa dos sistemas superiores e das múltiplas demandas sociais, os diferentes atores disputam os papéis que caberiam à educação superior frente ao Estado, à sociedade, ao mercado, à comunidade educativa, aos 'clientes', ao setor produtivo, bem como os diversos tipos de serviço que as instituições devem oferecer. Nessa disputa está claro que, atualmente, têm primazia as noções de qualidade e os modelos de avaliação e garantia de qualidade ancorados nas doutrinas e práticas neoliberais (DIAS SOBRINHO, 2008a, p. 817)

No Governo de Luiz Inácio Lula da Silva, que se iniciou em 2003, foi dada ênfase a outras políticas para a educação superior, especialmente no campo da ampliação do acesso a este nível educacional, tanto pela via pública, como a expansão da rede federal de ensino 
superior, via Programa de Apoio a Planos de Reestruturação e Expansão das Universidades Federais (Reuni), quanto pela rede privada, de maneira mais pronunciada, por meio de melhorias no Fundo de Financiamento Estudantil (Fies) e da criação do Programa Universidade para Todos (ProUni). Também, conforme foi destacado anteriormente, nesse período foi notável a ação conjunta destas políticas com a promoção de políticas afirmativas (baseadas na redução de desigualdades sociais envolvendo critérios de raça/etnia, renda, entre outros).

Portanto, segundo Barreyro e Rothen $(2011,2014)$, no Governo Lula a avaliação não assumiu o mesmo protagonismo (ou deixou de ter a centralidade) na agenda de políticas para a educação superior que teve no Governo FHC. No entanto, destaca-se que foi iniciado um novo ciclo de debates em torno dessa questão.

Durante o primeiro Governo Lula (2003-2006), dadas as crescentes críticas da comunidade acadêmica a respeito do método de avaliação do Provão e uma grande demanda por maior participação democrática (DIAS SOBRINHO, 2010), iniciaram-se novos debates em torno das duas concepções de avaliação antagônicas: a emancipatória versus a regulatória (modelos baseados no PAIUB e no Provão, respectivamente). Observa-se que, durante o Governo Lula, houve um espaço e uma influência maior desses debatedores na formulação, concepção e implementação das políticas públicas voltadas ao ensino superior - em contraponto ao Governo FHC, que desconsiderou estes debates na elaboração das políticas que foram efetivadas.

Durante esses debates, dos quais participaram diversos representantes da sociedade, como os movimentos sociais e a comunidade acadêmica, foi considerada uma proposta de avaliação emancipatória, baseada nos princípios desenvolvidos na época do PAIUB. Essa discussão se deu no âmbito da Comissão Especial de Avaliação (CEA), criada em 2003, composta por representantes da Secretaria de Educação Superior (SESu), do INEP, da Coordenação de Aperfeiçoamento de Pessoal de Nível Superior (CAPES), da União Nacional dos Estudantes (UNE) e de especialistas de universidades públicas e privadas (BARREYRO e ROTHEN, 2006).

Esses embates, entre idas e vindas em torno de diferentes propostas de avaliação, acabaram resultando na aprovação da Lei $\mathrm{n}^{\circ}$ 10.861, de 14 de abril de 2004, que instituiu o Sistema Nacional de Avaliação da Educação Superior (SINAES), o sistema de avaliação vigente no país. Na seção seguinte, serão apresentados mais detalhes sobre a sua implantação e operacionalização. 


\subsection{O Sistema Nacional de Avaliação da Educação Superior (SINAES)}

O Sistema Nacional de Avaliação da Educação Superior (SINAES) foi criado em 2004 com o objetivo de realizar um processo de avaliação da educação superior brasileira orientado em três eixos: avaliação das instituições de educação superior, dos cursos de graduação e do desempenho acadêmico dos estudantes. Segundo a legislação oficial, o SINAES tem por finalidade

[...] a melhoria da qualidade da educação superior, a orientação da expansão da sua oferta, o aumento permanente da sua eficácia institucional e efetividade acadêmica e social e, especialmente, a promoção do aprofundamento dos compromissos e responsabilidades sociais das instituições de educação superior, por meio da valorização de sua missão pública, da promoção dos valores democráticos, do respeito à diferença e à diversidade, da afirmação da autonomia e da identidade institucional (BRASIL, 2004b, Art $1^{\circ} \S 1^{\circ}$ )

Nesse período, também, foi criada a Comissão Nacional de Avaliação da Educação Superior (CONAES), um órgão colegiado que possui como atribuição a supervisão e coordenação do SINAES. A CONAES possui um papel bastante relevante para o sistema de avaliação, já que estabelece os parâmetros e diretrizes para sua operacionalização (POLIDORI, MARINHO-ARAÚJO e BARREYRO, 2006). São atribuições da CONAES: proposição e avaliação das dinâmicas e mecanismos de avaliação institucional, de cursos e do desempenho dos estudantes; estabelecimento de diretrizes para as comissões de avaliação, desde a análise de relatórios, redação de pareceres e propostas para as IES, tendo como base os processos de avaliação realizados; entre outras (BRASIL, 2004b). Já a operacionalização do SINAES ficou a cargo do INEP.

Por meio da instituição do SINAES em 2004, foi sinalizada uma "mudança na concepção de avaliação" (BARREYRO e ROTHEN, 2006, p. 971) na educação superior brasileira, pois, conforme mencionado, foi criado um sistema integrado de avaliação de três eixos: avaliação de cursos, instituições e do desempenho dos estudantes, possuindo como uma dos principais pontos norteadores a avaliação institucional, externa e interna, incluindo a centralidade no processo de autoavaliação, com intensa participação dos atores da comunidade acadêmica (POLIDORI, MARINHO-ARAÚJO e BARREYRO, 2006; DIAS SOBRINHO, 2008a).

Para concretizar a proposta de um sistema de avaliação integrado, a Lei do SINAES previu o estabelecimento de mecanismos de avaliação institucional (autoavaliação e avaliação 
externa); a avaliação de cursos de graduação, contemplando visitas presenciais de comissões de especialistas, por áreas de conhecimento; e a avaliação dos estudantes, por meio de uma prova de larga escala, o Exame Nacional de Desempenho dos Estudantes (ENADE).

Nesse âmbito, a Lei do SINAES foi considerada para Barreyro e Rothen (2011, p. 83) como "uma lei híbrida, pois objetiva conciliar a avaliação emancipatória com a regulação do sistema". Ou seja, os documentos oficiais relativos à proposta do sistema misturavam elementos de visão emancipatória, baseando-se num conceito de avaliação integrada globalmente, e elementos próprios da visão controladora/regulatória do sistema - principalmente, por ter sido mantida uma prova que avalia o desempenho de estudantes em larga escala, o ENADE, no lugar do Provão.

Dias Sobrinho (2008a) destacou que a criação de um sistema amplo de avaliação interna e externa educacional, inclusive para promover melhorias nos processos acadêmicos, fazia parte das metas e objetivos previstos do Plano Nacional de Educação (PNE) 2001-2010. Ainda, o SINAES foi proposto de maneira ampla e diversificada em suas premissas, visando a articulação entre várias "dimensões educativas e institucionais, diferentes metodologias, procedimentos, objetos e objetivos, instâncias da comunidade acadêmico-científica e do Estado, auto-avaliação e avaliação externa, auto-regulação e regulação, etc.” (DIAS SOBRINHO, 2008a, p. 820). Portanto, o tripé de avaliação seria baseado na combinação de diferentes aspectos metodológicos, instrumentos e operações (LACERDA, 2015).

No desenvolvimento das avaliações das IES, foram implementados, conforme a proposta inicial, processos de autoavaliação institucional interna por intermédio das Comissões Próprias de Avaliação (CPAs), formadas em cada Instituição de Ensino Superior, que organizam e coordenam esse processo. A CPA, contando com a participação de atores institucionais, representantes da sociedade civil e de outros segmentos da comunidade, remete ao conceito de avaliação institucional previamente idealizada no PAIUB, especialmente no que tange ao conceito de autonomia dessas instituições (BARREYRO e ROTHEN, 2006). Após essa avaliação interna, também é prevista outra etapa, a avaliação externa dessas IES, por meio das visitas in loco realizada por comissões de especialistas (POLIDORI, MARINHO-ARAÚJO e BARREYRO, 2006).

Entretanto, cabe ressaltar que, em maio de 2006, foi editado o Decreto $\mathrm{n}^{\circ} 5.773$ - mais conhecido como "Decreto Ponte" entre avaliação e regulação, que realizou algumas mudanças em relação à organização da educação superior, entre elas a articulação dos instrumentos de regulação, avaliação e supervisão, atrelando esses aspectos à nova regulamentação do SINAES 
(BARREYRO e ROTHEN, 2006). Entre estas mudanças estão, por exemplo, a atribuição de responsabilidade às Secretarias do MEC e do Conselho Nacional de Educação para os atos de credenciamento/autorização e recredenciamento dos cursos e instituições, enfatizando o papel da fiscalização (BARREYRO e ROTHEN, 2014); e atribuiu ao INEP a competência de elaborar instrumentos de avaliação para credenciamento de instituições e autorizações de cursos. Segundo os autores, o decreto seguiu a tendência de "separar a autoavaliação da avaliação externa, retirando assim a centralidade da autoavaliação", estabelecendo fronteiras mais claras entre os processos de avaliação e regulação (BARREYRO e ROTHEN, 2006, p. 970)

Nesse sentido, a autoavaliação institucional, especialmente em torno das CPAs, foi perdendo espaço no modelo de avaliação da educação superior do SINAES. Além disso, conforme citam Barreyro e Rothen (2014), estudos acadêmicos e técnicos relacionados às CPAs indicam que a implantação desses dispositivos foi um processo muito heterogêneo em relação aos diferentes tipos de IES, cujos relatórios de autoavaliação possuem diferentes graus de aprofundamento. Em muitos casos, os relatórios revelaram-se apenas como processos burocráticos de cumprimento da legislação, não constituindo análises autocríticas por parte das IES. Não obstante, como será exposto mais a frente, esse processo se intensificou com a maior ênfase dada na operacionalização do SINAES aos resultados de provas de larga escala e a criação de elementos quantitativos, na forma de indicadores, para a avaliação de estudantes, cursos e instituições, em um processo de reforço das práticas de fiscalização e supervisão no sistema.

Para concretizar o eixo de avaliação dos cursos de graduação, a Lei do SINAES previu a utilização de "procedimentos e instrumentos diversificados" (BRASIL, 2004b, Art. $4^{\mathrm{o}} \S 1^{\mathrm{o}}$ ), considerando em especial as dimensões dos cursos relativas ao corpo docente, instalações físicas e organização didático-pedagógica, para as quais a visita de avaliadores externos (comissão de especialistas das respectivas áreas de conhecimento) é colocada como obrigatória.

Para instituir a avaliação dos estudantes desses cursos, foi criado o Exame Nacional de Desempenho dos Estudantes (ENADE), que será discutido de forma mais aprofundada na próxima seção.

\subsubsection{O Exame Nacional de Desempenho dos Estudantes (ENADE)}

Entre as mudanças instituídas no âmbito do SINAES, destaca-se o surgimento do Exame Nacional de Desempenho dos Estudantes (ENADE), ainda em 2004, para concretizar o eixo da 
avaliação de desempenho dos estudantes. O exame é realizado pelo INEP, sob supervisão da CONAES, que, segundo a legislação oficial, busca aferir

[...] o desempenho dos estudantes em relação aos conteúdos programáticos previstos nas diretrizes curriculares do respectivo curso de graduação, suas habilidades para ajustamento às exigências decorrentes da evolução do conhecimento e suas competências para compreender temas exteriores ao âmbito específico de sua profissão, ligados à realidade brasileira e mundial e a outras áreas do conhecimento (BRASIL, 2004b, Art. $5^{\circ} \S 1^{\circ}$ ).

O ENADE constituiu-se como um elemento curricular obrigatório dos cursos de graduação, inclusive passando a ser registrado no histórico escolar dos estudantes. As IES são responsáveis pela inscrição dos alunos habilitados à participação no ENADE. Já a CONAES é responsável pela submissão da relação de áreas e cursos que serão avaliados anualmente (BRASIL, 2004b, Art. $6^{\circ}$ ).

Inicialmente, ou seja, a partir de 2004, estavam habilitados para participar do ENADE os estudantes ingressantes e concluintes das áreas e cursos a serem avaliados, uma inovação tendo em vista seu antecessor, o Provão, que era aplicado somente aos alunos concluintes. Além disso, a aplicação tanto para ingressantes quanto para concluintes tinha em vista estimar o valor agregado pelos cursos e instituições aos alunos (BARREYRO e ROTHEN, 2014). O modelo de aplicação, que era amostral, perdurou de 2004 a 2008. Em 2009, a prova se tornou censitária. Com o decorrer dos anos, o Exame passou por uma série de mudanças em sua aplicação, o que será explicado mais à frente.

Os instrumentos básicos de avaliação do ENADE são (BRASIL, 2015e):

- O próprio Exame (ou prova), dividido em:

○ Formação Geral, ou seja, contempla questões de conhecimentos gerais (10 questões, sendo 8 de múltipla escolha e 2 discursivas);

- Componente Específico, relacionado aos conteúdos de cada curso (30 questões, sendo 27 de múltipla escolha e 3 discursivas);

○ Questionário de percepção sobre a prova.

- Questionário do Estudante, que busca levantar o perfil dos alunos por meio de informações socioeconômicas, além de ter o objetivo de captar a percepção dos discentes sobre questões acadêmicas, como infraestrutura, organização didáticopedagógica e processos formativos; 
- Questionário do Coordenador(a) de curso, que busca levantar informações sobre o perfil do curso.

Desde a sua criação, o exame do ENADE atribui conceitos, denominados de Conceito ENADE, expressos em uma escala de cinco níveis ( 1 a 5), que passam a integrar e subsidiar o conjunto das dimensões avaliadas dos cursos de graduação e da avaliação institucional. A Nota do ENADE configura-se, atualmente ${ }^{29}$, como uma média ponderada da nota padronizada dos estudantes concluintes na Formação Geral (peso de 25\%) e no Componente Específico (peso de $75 \%)$.

O ENADE é aplicado somente a alguns grupos de cursos a cada ano. A Portaria Normativa MEC no 40/2007, republicada em 2010, instituiu que o Exame será realizado anualmente, porém apenas trienalmente a cada curso. A partir destas disposições, foi então instituído um calendário de áreas a serem avaliadas a cada ano, considerando os diversos tipos de formações:

O ENADE será realizado todos os anos, aplicando-se trienalmente a cada curso, de modo a abranger, com a maior amplitude possível, as formações objeto das Diretrizes Curriculares Nacionais, da legislação de regulamentação do exercício profissional e do Catálogo de Cursos Superiores de Tecnologia. $\S 1^{\circ} \mathrm{O}$ calendário para as áreas observará as seguintes referências:

a) Ano I- saúde, ciências agrárias e áreas afins;

b) Ano II- ciências exatas, licenciaturas e áreas afins;

c) Ano III- ciências sociais aplicadas, ciências humanas e áreas afins.

$\S 2^{\circ} \mathrm{O}$ calendário para os eixos tecnológicos observará as seguintes referências:

a) Ano I- Ambiente e Saúde, Produção Alimentícia, Recursos Naturais, Militar e Segurança;

b) Ano II- Controle e Processos Industriais, Informação e Comunicação, Infraestrutura, Produção Industrial;

c) Ano III- Gestão e Negócios, Apoio Escolar, Hospitalidade e Lazer, Produção Cultural e Design. (BRASIL, 2010a, Art. 33-E)

A escolha dos cursos que serão avaliados nessas áreas é realizada pela CONAES e definida por meio de portarias específicas. Para ilustrar melhor a questão, o primeiro ENADE foi aplicado em 2004 (ou seja, Ano I: referente à Saúde, Ciências Agrárias e áreas afins, para bacharelados e licenciaturas, e Ambiente e Saúde, Produção Alimentícia, Recursos Naturais, Militar e Segurança para os cursos tecnológicos), avaliando as áreas de enquadramento ${ }^{30} \mathrm{de}$ :

\footnotetext{
${ }^{29}$ Referente à edição do ENADE de 2015.

${ }^{30}$ As áreas de enquadramento referem-se ao "o processo pelo qual a IES identifica a área de conhecimento a ser avaliada pelo ENADE mais correlacionada ao projeto pedagógico do seu curso" (BRASIL, 2015f, p. 10).
} 
Agronomia, Educação Física, Enfermagem, Farmácia, Fisioterapia, Fonoaudiologia, Medicina, Medicina Veterinária, Nutrição, Odontologia, Serviço Social, Terapia Ocupacional e Zootecnia $^{31}$.

No ano de 2006, com base nos resultados do ENADE, também começou a ser calculado o Indicador de Diferença entre os Desempenhos Observado e Esperado (IDD), ou seja, um conceito que mede a diferença entre o desempenho médio dos concluintes de um curso e o desempenho médio estimado para os concluintes desse mesmo curso. Este conceito representa uma das inovações relativas ao SINAES, pois visa mensurar as diferenças em relação ao perfil dos estudantes ao ingressar e ao concluir o ensino superior. Com o resultado desse indicador, os cursos "nos quais o desempenho dos ingressantes é próximo ao dos concluintes tem uma má avaliação, ao passo que são bem-avaliados aqueles em que o desempenho dos concluintes é superior ao dos ingressantes" (BARREYRO e ROTHEN, 2014, p. 68).

\subsubsection{Principais mudanças metodológicas do ENADE}

Conforme adiantado anteriormente, verifica-se que o ENADE passou por uma série de mudanças metodológicas desde seu surgimento. O modelo de aplicação, que era amostral, perdurou de 2004 a 2008. Em 2009, a prova se tornou censitária, ou seja, realizada com todos os estudantes (BRASIL, 2015e).

Uma importante mudança se deu com relação aos estudantes aptos a realizar a prova. Inicialmente, era aplicada anualmente com os estudantes de primeiro ano (ingressantes) e último ano (concluintes) dos cursos de graduação. No entanto, por meio da Portaria Normativa MEC n ${ }^{\circ} 40 / 2010$, foi instituída a dispensa da participação de alunos ingressantes a partir do Enade 2011, em face da ampliação do Exame Nacional do Ensino Médio (ENEM) ${ }^{32}$ (BRASIL, 2012c). Não obstante, a partir desse ano, o aluno ingressante que tiver realizado o ENEM, está dispensado de realizar a prova de Formação Geral do ENADE. Essa substituição gerou críticas, como as de Barreyro e Rothen (2014), já que

\footnotetext{
Segundo as diretrizes oficiais, a escolha do enquadramento dos cursos de graduação nas respectivas áreas divulgadas pelo ENADE a cada ano é de responsabilidade da IES, conforme orientações técnicas do INEP.

${ }^{31}$ A relação de áreas e cursos avaliados anualmente pelo ENADE encontra-se no Anexo A deste trabalho.

32 O ENEM avalia o desempenho dos estudantes ao final da educação básica. Foi criado em 1998, e a partir de 2009, passou a ser utilizado como mecanismo de alguns processos seletivos para ingresso na educação superior.
} 
[...] o ENEM e o ENADE são provas diferentes, com objetivos diferentes. O ENEM é uma prova realizada seguindo a Teoria de Resposta ao Item $^{33}$ e o ENADE não, ou seja, os resultados do primeiro podem ser comparados de um ano para o outro, enquanto o mesmo não pode ser feito com o segundo. Dessa forma, seria criada uma diferença, no interior do ENADE, entre resultados comparáveis e não comparáveis (BARREYRO e ROTHEN, 2014, p. 72)

Além disso, a prova de Formação Geral passou a ter como base a matriz de referência do ENEM, revelando grandes mudanças em relação ao ENADE original proposto pelo SINAES, que "não cogitava auferir os conhecimentos obtidos no ensino médio, mas sim o valor agregado do curso" (BARREYRO e ROTHEN, 2014, p. 72).

Em 2013, também, ocorreu uma revisão ${ }^{34}$ dos Questionários que acompanham a prova (Estudante e Coordenador), e foi instituída a obrigatoriedade de tempo mínimo para a permanência no local de realização do Exame.

Mesmo em constante transformação, o ENADE desempenha um papel de relevância na avaliação da educação superior, na medida em que contribui

[...] tanto no processo de avaliação institucional, fornecendo subsídios para que as IES alimentem a dinâmica da auto-avaliação quanto na formulação de políticas públicas para o sistema de educação superior do país. Nesse sentido, o ENADE pretende proporcionar reflexão no interior do próprio curso e da instituição, na medida em que se constitui como um momento privilegiado de interlocução com os estudantes, visando a estimular a reflexão crítica e a avaliação de seus processos formativos (POLIDORI, MARINHO-ARAÚJO e BARREYRO, 2006, p. 434)

Além disso, de acordo com dados do INEP (BRASIL, 2015g), o Exame têm expandido sua abrangência de avaliação na educação superior. Os dados mostram que o número de cursos em que foi aplicado o ENADE passou de 2.184, em 2004, para 9.994, em 2014, ou seja, mais que quadruplicou em dez anos. O número de estudantes avaliados passou de $140 \mathrm{mil} \mathrm{em} 2004$ para 483 mil em 2014.

\footnotetext{
${ }^{33}$ A Teoria de Resposta ao Item (TRI) é uma metodologia utilizada para mensurar o desempenho dos alunos em diversos tipos de provas de larga escala, buscando estabelecer uma trajetória das aferições dos resultados obtidos, ou seja, permitiu a construção de séries históricas (MACHADO e ALAVARSE, 2014).

${ }^{34}$ De acordo com o INEP (BRASIL, 2014a), a revisão contribuiu de forma a produzir outros tipos de insumos sobre a percepção dos estudantes. Como resultado desse processo, no próprio ano de 2013 foi aplicada uma nova versão do Questionário do Estudante no ENADE, com significativas mudanças que ampliaram as fontes de percepção discente de dois (2) itens, para 42, e incluindo, além de novas questões sobre Organização DidáticoPedagógica e Infraestrutura, também em relação às Oportunidades de ampliação da Formação Acadêmica e Profissional.

Os Questionários do Estudante de 2012 e 2013 estão disponíveis no Anexo B deste trabalho.
} 
Para Dias Sobrinho (2010), aos poucos, o ENADE começou a adquirir destaque na sociedade, alcançando até certa autonomia em relação ao SINAES, tornando-se sinônimo de avaliação em sentido pleno, muito mais do que todo o sistema. Esse processo se intensificou pois, assim como no modelo de avaliação anterior (o Provão), foi mantida uma prova de larga escala e a utilização dos resultados da avaliação em cinco níveis, possibilitando o ranqueamento das IES - procedimento este que, inclusive, foi realizado pelo próprio MEC uma vez, em 2008 (DIAS SOBRINHO, 2010), movimento aliado aos ranques tradicionalmente realizados pelos veículos midiáticos - situação que também estimulou a concorrência entre as IES, além de impactar essas instituições como um todo, inclusive, ao adaptarem os conteúdos de seus cursos aos exigidos pelas provas (BERTOLIN e MARCON, 2015).

As limitações encontradas na divulgação de indicadores do ENADE para fins de construção de estatísticas educacionais são várias: não há possibilidade de comparar os cursos avaliados num mesmo ano, ou mesmo os resultados dos cursos nas diversas avaliações trienais, pois, conforme apontado anteriormente, "a prova do ENADE não permite comparações, diferentemente da prova do ENEM, que se utiliza da Teoria de Resposta ao Item e permite comparações entre provas de diferentes anos" (BARREYRO e ROTHEN, 2014, p. 71). Somase a essa situação o fato de que os resultados divulgados são, na maioria das vezes, muito simplificados, como costumam ser por meio dos exames de larga escala.

Entretanto, é importante ressaltar que tais avaliações com ênfase nos resultados, como o ENADE, são consideradas importantes para subsidiar políticas públicas educacionais: "não há dúvida que os exames em larga escala são úteis para subsidiar as ações dos operadores do estado concernentes à educação" (DIAS SOBRINHO, 2010, p. 206). Entretanto, é pertinente que esses exames não percam o viés pedagógico e os processos formativos envolvidos em sua formulação, de forma a não resumir seus resultados em aparatos técnicos e burocráticos: “é comum que assumam caráter tecnocrático e induzam na comunidade educativa o cumprimento burocrático e formal das exigências e padrões” (DIAS SOBRINHO, 2010, p. 206).

Todavia, além da grande importância que o ENADE adquiriu ao longo dos anos para a avaliação do desempenho dos estudantes, os resultados do conjunto de instrumentos de avaliação contidos no Exame começaram a ser utilizados para a produção de outros indicadores de avaliação da educação superior, como o Conceito Preliminar de Curso (CPC) e o Índice Geral de Cursos (IGC). 
O CPC e o IGC foram criados, no âmbito do SINAES, para concretizar os eixos de avaliação de cursos e de instituições. Esses indicadores serão discutidos de forma mais aprofundada na próxima seção.

\subsubsection{O Conceito Preliminar de Curso (CPC) e o Índice Geral de Cursos (IGC)}

Foram criados, ainda no ano de 2008, outros dois indicadores de avaliação no SINAES: o Conceito Preliminar de Curso (CPC) e o Índice Geral de Cursos (IGC). O contexto de surgimento desses indicadores está relacionado com a proposta abrangente de avaliação do Sistema, que compreende a:

[...] necessidade das IES passarem por um ciclo completo de avaliação. Esse ciclo envolve os três pilares do Sistema, ou seja, a avaliação institucional, a avaliação de cursos e a avaliação de desempenho dos estudantes. No entanto, o ciclo desse Sistema não pode ser considerado como uma dinâmica linear. Cada pilar compreende vários estágios e atuações que se diferem de IES para IES (POLIDORI, 2009, p. 446).

Além disso, o surgimento do CPC e do IGC está relacionado também à situação de represamento de processos de credenciamento de instituições e reconhecimento de cursos durante o primeiro Governo Lula (2003-2006), o que gerou a necessidade de medidas legais para resolver esses problemas (BARREYRO e ROTHEN, 2014). Nesse contexto, foi editada a Portaria Normativa MEC no 40 de $2007^{35}$, que além de instituir o E-MEC (sistema eletrônico para gerenciar os processos de regulação, avaliação e supervisão da educação superior), também flexibilizou a necessidade da avaliação in loco para os processos de renovação de reconhecimento de cursos superiores, característica que constituía, conforme assinalam Barreyro e Rothen (2014), um dos objetivos obrigatórios previstos na Lei do SINAES (visitas presenciais realizadas por comissões de especialistas das respectivas áreas do conhecimento). Consta também, na Portaria, que essa avaliação presencial poderia ser dispensada com o resultado de um novo indicador, na forma de um conceito preliminar de curso. Esse conceito preliminar seria produzido com base em informações das IES e dos cursos, do Censo da Educação Superior e dos resultados do ENADE.

\footnotetext{
${ }^{35}$ A Portaria foi posteriormente republicada em 2010, conforme já mencionado. No entanto, neste momento, nos interessa a citação da edição original de 2007.
} 
A aplicação desse conceito, posteriormente denominado de Conceito Preliminar de Curso (CPC), foi regulamentada em agosto de 2008 por meio da Portaria Normativa MEC n $^{\circ}$ 4. Também durante o ano de 2008, mas em setembro, foi instituído o Índice Geral de Cursos Avaliados da Instituição (IGC) pela Portaria Normativa no 12. Apesar de já estarem em vigor desde essa época, no entanto, tanto o CPC quanto o IGC somente foram oficializados como indicadores de qualidade na educação superior para cursos e instituições, respectivamente, com a republicação de 2010 da Portaria Normativa MEC nº 40, em que consta:

São indicadores de qualidade, calculados pelo INEP, com base nos resultados do ENADE e demais insumos constantes das bases de dados do MEC, segundo metodologia própria, aprovada pela CONAES, atendidos os parâmetros da Lei $n^{\circ} 10.861$, de 2004:

I - de cursos superiores: o Conceito Preliminar de Curso (CPC), instituído pela Portaria Normativa ${ }^{\circ}$ 4, de 05 de agosto de 2008;

II - de instituições de educação superior: o Índice Geral de Cursos Avaliados da Instituiçãa (IGC), instituído pela Portaria Normativa $\mathrm{n}^{\circ} 12$, de 05 de setembro de 2008;

III - de desempenho de estudantes: o conceito obtido a partir dos resultados do ENADE; (BRASIL, 2010a, Art. 33-B, grifo meu).

Para o INEP, o CPC e o IGC fazem parte das "medidas da qualidade dos cursos e das Instituições do país, utilizados tanto como referenciais no desenvolvimento de políticas públicas para a Educação Superior quanto como fonte de consultas pela sociedade" (BRASIL, 2013, p. 5).

$\mathrm{O} \mathrm{CPC}^{36}$, indicador de qualidade dos cursos de graduação, é calculado no ano seguinte à realização do ENADE, e possui como pilares de avaliação as dimensões: corpo docente, instalações físicas e organização didático-pedagógica - composto de informações, já existentes, sobre as Instituições de Ensino Superior que ofertam os cursos e também respostas dos estudantes sobre as três dimensões avaliadas -, além do desempenho médio dos estudantes, estes dois últimos insumos obtidos a partir dos resultados na prova do ENADE e do Questionário do Estudante que o acompanha.

O Índice Geral de Cursos (IGC), utilizado para avaliar as instituições de ensino superior, é calculado considerando a média dos conceitos dos cursos de graduação (CPCs) em cada IES e de programas de pós-graduação. O procedimento, segundo a legislação oficial, consiste em agregar

\footnotetext{
${ }^{36}$ Por ser um dos objetos centrais de discussão nesta pesquisa, o CPC será tratado de forma mais aprofundada no Capítulo 3.
} 
I - a média dos últimos CPCs disponíveis dos cursos avaliados da instituição no ano do cálculo e nos dois anteriores, ponderada pelo número de matrículas em cada um dos cursos computados;

II - a média dos conceitos de avaliação dos programas de pós-graduação stricto sensu atribuídos pela CAPES na última avaliação trienal disponível, convertida para escala compatível e ponderada pelo número de matrículas em cada um dos programas de pós-graduação correspondentes;

III - a distribuição dos estudantes entre os diferentes níveis de ensino, graduação ou pós-graduação stricto sensu, excluindo as informações do inciso II para as instituições que não oferecerem pós-graduação stricto sensu (BRASIL, 2010a, Art. 33-B § $2^{\circ}$ )

Tanto o CPC quanto o IGC são divulgados anualmente, cujos conceitos emitidos, em escala de cinco níveis, devem ser iguais ou superiores a "3", que indicam qualidade "satisfatória" (BRASIL, 2010a, Art. 33-A § $2^{\circ}$ ) para as IES e para os cursos de graduação. Ainda, no caso do CPC, o conceito satisfatório pode subsidiar ou até mesmo resultar na dispensa da necessidade de avaliação presencial: nestes casos, é facultativo à IES o requerimento da visita, caso queiram modificar ou confirmar o CPC atribuído previamente. Esse fato foi responsável por reduzir drasticamente o número de visitas realizadas pelas comissões de especialistas após a criação desses indicadores (ROTHEN E BARREYRO, 2011). Por outro lado, se a nota final obtida do CPC for inferior a três (considerada insatisfatória), o curso, obrigatoriamente, deve submeter-se à avaliação presencial.

Quando o CPC ou o IGC servem de subsídio para os processos de avaliação presenciais, essas avaliações resultam em outros dois conceitos: o Conceito Institucional (CI) e o Conceito de Curso (CC):

São conceitos de avaliação, os resultados após avaliação in loco realizada por Comissão de Avaliação do INEP:

I - de curso: o Conceito de Curso (CC), consideradas, em especial, as condições relativas ao perfil do corpo docente, à organização didáticopedagógica e às instalações físicas;

II - de instituição, o Conceito de Instituição (CI), consideradas as dimensões analisadas na avaliação institucional externa. (BRASIL, 2010a, Art. 33-C)

Para Barreyro e Rothen (2014), diferentemente de outras políticas relativas à educação superior implementadas no período, esses indicadores não passaram por processos de consulta pública, sendo instituídos por portarias em um processo meramente operacional, por demanda do SINAES, o que gerou muitas críticas da comunidade acadêmica na época, não só pelo processo legislativo, mas também na própria construção dos indicadores e sua articulação com o SINAES. 
Esses índices normalmente são criticados na literatura sobre avaliação da educação superior, por possuírem tendências exageradamente economicistas e gerenciais (BARREYRO e ROTHEN, 2011), além de deixarem dúvidas sobre sua consistência técnica, resumindo a qualidade de instituições e cursos a médias ponderadas de variáveis pouco comparáveis entre si (ROTHEN e BARREYRO, 2011). A função destes índices costuma estar atrelada ao estabelecimento de metas de desempenho, o que, para os autores, certamente impacta mais no setor privado do que no público.

A criação desses índices e a associação a conceitos em escala numérica também gerou, assim como as práticas realizadas anteriormente no Provão, uma grande exposição na mídia, possuindo maior apelo popular na sociedade brasileira (ROTHEN e BARREYRO, 2011). Com isso, esses resultados muitas vezes acabam "se tornando um selo de qualidade e são utilizados para marketing institucional” (BARREYRO e ROTHEN, 2014, p. 73). Nesse movimento, é necessário ter em vista o caráter simplificador que muitas vezes reveste-os de uma aparência de verdades absolutas, representando o que deve ser tomado como indicador de qualidade de um curso ou uma instituição de ensino (POLIDORI, 2009).

Com esse movimento, o próprio ENADE, que serve de base para a formulação dos conceitos do CPC e do IGC, originalmente configurado como um dos componentes do SINAES, foi ganhando autonomia, passando a se revestir de objetividade e colocando em xeque os métodos de autoavaliação e as avaliações externas que constavam na proposta original do SINAES - agora métodos tidos como elementos "subjetivos" (DIAS SOBRINHO, 2010, p. 215). Esse movimento indica a centralidade e a ênfase para o uso da regulação (BARREYRO e ROTHEN, 2014; LACERDA e FERRI, 2015), deixando de lado outras propostas de avaliação integrada. Destaca-se o papel que foi adquirindo a avaliação, com a implementação dos índices:

\begin{abstract}
A avaliação deveria ser isenta de valores e exercer, sobretudo, função controladora. Daí o privilégio quase exclusivo de sua dimensão técnica e objetiva, com a finalidade de informar e orientar tanto a administração central como os usuários e consumidores do sistema educacional superior. Informações objetivas e supostamente não contaminadas por subjetivismos e interesses seriam fundamentais para a livre escolha dos clientes (DIAS SOBRINHO, 2010, p. 202).
\end{abstract}

Portanto, o ENADE, que trouxe algumas mudanças e inovações com relação a seu antecessor (o Provão), sendo considerado um avanço à época de sua criação (ROTHEN e BARREYRO, 2011), após as diversas transformações ocorridas no SINAES continua inserido de forma semelhante à lógica anterior, pois a partir dos resultados da prova são formulados, 
além do Conceito ENADE, os principais subsídios para o CPC e o IGC - indicadores que adquiriram grande destaque e apelo popular na sociedade, "mostrando que a lógica de regular o sistema pelos resultados de uma prova continua em vigor" (BARREYRO e ROTHEN, 2014, p. 61). Nesse sentido, com o IGC, “a avaliação institucional como auto-avaliação, eixo central do SINAES, parece não ter relevância no ranking das instituições divulgado pelo ministério, apesar de continuar vigente no SINAES” (BARREYRO, 2008b, p. 866).

Durante a história das políticas educacionais voltadas à avaliação da educação superior brasileira, especialmente na transição do Governo FHC para o Governo Lula, Rothen e Barreyro (2011) atestam que, postas algumas divergências e diferenças de encaminhamentos políticos, o uso do ranqueamento pela mídia e a simplificação dos métodos de avaliação permaneceram com o objetivo de regulação do sistema, fortalecendo a tendência mercadológica e o setor privado nesse nível educacional. Aos poucos, foi sendo destituído o método de avaliação de caráter formativo/participativo, ou seja, baseado na autoavaliação institucional (inclusive perdendo força as próprias Comissões Próprias de Avaliação (CPAs) presentes no interior das instituições, em um contexto que as IES foram desestimuladas a levar esse processo adiante). Situação semelhante ocorreu com as avaliações presenciais, dando-se ênfase à dimensão de controle/regulação da avaliação.

Ainda hoje, o que persiste nas políticas educacionais sobre avaliação é o papel do Estado como indutor da concorrência e competitividade entre as instituições de ensino, em que "predomina a ideia de que um exame em larga escala é um indicador suficiente e confiável para a avaliação da educação superior" (ROTHEN e BARREYRO, 2011, p. 23). Os resultados em forma de índices acabam legitimando as práticas envolvidas, pois

[...] comparações e resultados simplificados não são um mal em si, mas, dentro de uma lógica mercadológica, funcionam apenas como um fator de concorrência mercantil, em oposição à possível colaboração e troca de experiências visando a melhoria de qualidade (ROTHEN e BARREYRO, 2011, p. 27).

Conforme já mencionado, um dos exemplos práticos desse processo, como consequência da supervalorização de indicadores, é a reforma realizada pelas IES na grade curricular dos cursos de graduação, permitindo a adequação de seus currículos aos conteúdos solicitados na prova do ENADE (BERTOLIN e MARCON, 2015).

Portanto, os índices criados no âmbito do SINAES, embora possuam relevância no sentido de criar estatísticas educacionais, promovendo certa facilidade de realizar comparações 
em âmbito nacional e mundial, num contexto em que "as avaliações externas fazem parte da arquitetura global da avaliação" (DIAS SOBRINHO, 2008, p. 823), acabaram, ainda segundo o autor, adquirindo um destaque muito maior do que o próprio sistema integrado de avaliação: “contudo, não podem sufocar as práticas de diálogo e questionamentos próprios da avaliação institucional participativa que fazem das instituições espaços públicos de debates e reflexões" (DIAS SOBRINHO, 2008a, p. 823).

Verifica-se que a proposta de avaliação do SINAES, que pode representar avanços e transformações neste campo, no que tange à sua proposta original de unir concepções antagônicas de avaliação, ainda configura-se em processo de constante transformação e reformulação - fato que pode encontrar explicação, entre outros fatores, pelo caráter recente da política, e também pelas próprias contradições existentes no percurso da organização da educação superior brasileira, principalmente com relação à integração das propostas e políticas públicas direcionadas ao setor:

Muitas das incongruências do SINAES são resultado da tentativa de implantar uma sistemática de avaliação sem qualquer relação com a elaboração de um projeto de política de educação superior, isto é, sem discussão prévia do tipo de instituições desejado (BARREYRO e ROTHEN, 2006, p. 972)

Para Barreyro e Rothen (2011), desde o começo do debate sobre avaliação (década de 1980) até o momento presente, as políticas de avaliação do ensino superior brasileiro de fato se institucionalizaram. Muito embora sejam processos importantes face à expansão de instituições e cursos - sendo a educação superior um setor que enfrentou uma grande diversificação nos últimos anos -, a forma como a avaliação foi sendo realizada na agenda do país não procurou envolver a participação da comunidade acadêmica e promover a autonomia universitária. Pelo contrário, as políticas de avaliação deram ênfase à expansão do setor privado educacional, a partir da lógica de qualidade atrelada ao estímulo da competitividade entre as IES.

No decorrer do resgate histórico das políticas voltadas para avaliação da educação superior brasileira, foi possível perceber que essas políticas acabaram dando ênfase mais a um paradigma que envolve órgãos de controle e gestão, do que propriamente à discussão sobre qualidade da educação e processos formativos, em busca da promoção da participação acadêmica, da autonomia universitária e melhoria dos processos educacionais. Nesse sentido concorda-se que 
Obviamente, sempre haverá contradições e imperfeições num sistema de avaliação, pois se trata de um fenômeno social e construção histórica. Nisso consiste a riqueza da avaliação: nunca está acabada, nem fechada às diferentes interpretações e aos distintos interesses de grupos, não é neutra nem detentora da verdade absoluta, mas precisa se esforçar para ser justa e socialmente eficaz

(DIAS SOBRINHO, 2010, p. 223).

Ainda que o SINAES, sistema de avaliação vigente no país, tenha representado um avanço neste sentido - no que tange à sua proposta original de unir concepções antagônicas de avaliação, simbolizado na época pelo objetivo de "reconhecer a diversidade do sistema de educação superior do país, respeitar a identidade, a missão e a história das IES, entender que essas devem ser avaliadas globalmente e ainda buscar a continuidade do processo avaliativo" (POLIDORI, 2009, p. 445), é possível perceber que, atualmente, passados mais de dez anos de sua instituição, o sistema ainda é objeto de constante transformação e aprimoramento, inclusive passando por diversas mudanças metodológicas nos indicadores e instrumentos de avaliação.

Portanto, em síntese, o que se verifica é que ainda predomina o debate entre as duas concepções de avaliação, em que o modelo vigente sofre críticas da comunidade acadêmica, por constituir um processo em que a reflexão sobre os valores de conhecimento (formativos) sofre prejuízos, em relação à sua substituição pela ênfase em recursos classificatórios, competitivos e controladores, focalizando mais os resultados do que os processos.

Durante o levantamento das políticas de avaliação da educação superior no Brasil, um dos pontos no qual emergiram questionamentos foi o tema da qualidade da educação superior. Foi possível perceber que essa discussão ficou, de certa maneira, em segundo plano, sendo relacionada ao plano técnico e quantitativo; e, até mesmo, restringida às demandas do mercado (DIAS SOBRINHO, 2010). Diante deste quadro, surgiu a necessidade de discutir essa questão a partir de perspectivas teóricas mais amplas. Tendo em vista o foco de investigação e os objetivos dessa dissertação, considerou-se importante aprofundar o tema da qualidade (entre as diferentes concepções, importância e sua articulação com as políticas de avaliação), o que será realizado na próxima seção.

\subsection{Qualidade e Avaliação da Educação Superior}

Nesta seção, o objetivo é discutir as relações entre qualidade e avaliação da educação superior, com base no levantamento bibliográfico envolvendo os dois temas. Para tanto, primeiramente é problematizado o conceito de qualidade, trazendo algumas das diferentes visões da literatura da área para o termo - que é conhecido por dificilmente encontrar consensos. 
Na sequência, o objetivo é tratar do debate sobre a questão da qualidade nas políticas de avaliação vigentes no Brasil, de forma a explicitar os limites e possibilidades nesse contexto.

\subsubsection{Qualidade da Educação Superior: concepções e importância}

O tema da qualidade da educação superior constitui, por si só, um campo complexo e de difícil mensuração, conhecido pela falta de construção de consensos no âmbito do debate educacional - não apenas brasileiro, mas mundial. Para Sguissardi (2006, p. 71, grifos do autor), “qualidade é daqueles termos polissêmicos, ou camaleônicos, que mimetizam significados e cores do contexto que os produz ou que condiciona sua existência".

Por outro lado, entende-se que o caráter polissêmico envolvido não deve ser utilizado como pretexto para fugir da discussão em torno de seus significados, processos de construção e de aplicação. Conforme aponta Sousa (2009, p. 244), “em qualquer contexto social, político e econômico, uma determinada concepção de qualidade ganha prevalência sobre as demais sem, contudo, implicar a extinção de outras com as quais convive".

Com relação à produção intelectual sobre o conceito, nota-se que qualidade é um termo que pode não comportar uma definição específica, ou cuja discussão encontra-se diluída em outras acerca do tema, como a da avaliação educacional. Muitas vezes, como entende Dias Sobrinho (2008a, p. 817), mesmo sendo um tema amplamente utilizado na agenda da educação superior, "o conceito de qualidade nem mesmo é posto em foco de discussão", ou ainda, se constata "uma ampla diversidade e uma certa confusão na utilização conceitual do termo 'qualidade' no âmbito da educação superior. As diferenças no entendimento e na aplicação são tantas que propiciaram uma espécie de vulgarização do termo" (BERTOLIN, 2009, p. 128).

Assim como para Dias Sobrinho (2008a) e Sousa (2009), também para Morosini (2009) esta discussão encontra pouco consenso, tanto em relação à qualidade do ensino ofertado, quanto da instituição que oferece este ensino. São conceitos construídos durante o andamento dos processos, cuja concepção de qualidade não é clara, mas cabe esclarecer por quem e para quem ela se presta.

Ao tentar entender de forma mais ampla a questão da qualidade da educação superior, primeiramente é necessário fazer um levantamento histórico acerca das mudanças da sociedade contemporânea, que influenciaram e transformaram radicalmente o setor educacional. Estas mudanças, de caráter político, econômico e social (principalmente em torno de novas exigências da sociedade capitalista, trazendo novas relações de informação e tecnologia e a emergência de 
outros modelos de relação econômica, como a globalização e neoliberalismo), trouxeram inúmeros desafios para o sistema de educação - cujo foco aqui é o de educação superior -, em um contexto de mudança de paradigmas.

Cabral Neto e Castro (2007) sustentam que na América Latina, após a década de 1980, foi sedimentado um modelo homogêneo de gestão dos sistemas educacionais na região, de forma a se adequar às novas exigências do modelo capitalista, que se funda em princípios como “[...] moderna administração adotada no âmbito empresarial e apresenta como principais características a flexibilidade, a agilidade, a eficiência, a eficácia e a produtividade" (CABRAL NETO e CASTRO, 2007, p. 15). Todas estas características possuem reflexos profundos na forma de organização de uma sociedade, em todos os seus aspectos: econômicos, sociais, políticos, psicológicos, laborais, educacionais, etc.

De acordo com Oliveira (2009), as consequências das mudanças na sociedade contemporânea, em especial por meio de novos modelos econômicos com o neoliberalismo e o advento da globalização, trouxeram um jogo de tensões e contradições para a área educacional, tais como: a educação como ponto fundamental para o desenvolvimento do processo produtivo e da preparação para o mercado de trabalho; a introdução de novas tecnologias no processo educativo (padronização de sistemas); e, como fenômeno mais recente, a transformação da educação em objeto do mercado, como setor econômico passível de comercialização. Nesta esteira de mudanças do setor, surgem empresas, fundações, vendas de todos os tipos de serviços educacionais, sistemas de educação a distância, cursos de formação flexível e de menor duração buscando a rápida entrada no mercado de trabalho, diversificação de cargos de trabalho, precarização das relações de trabalho (como a terceirização), entre outras consequências relacionadas à mercantilização do setor.

Conforme já observado no início deste Capítulo, sobre a trajetória da educação superior, neste contexto de transformações as IES acabaram por diversificar suas organizações, tornandose cada vez mais complexas com o propósito de atender as novas demandas da sociedade. A nova agenda política e econômica trouxe como consequências, também no caso brasileiro, as reformas do Estado, o que ocasionou mudanças institucionais nos sistemas educacionais, resultando em novas relações entre o público e o privado, constituindo um traço marcante deste processo a redução de investimentos públicos no setor educacional, ao passo que se valorizam os investimentos privados - uma tendência praticamente universal (DIAS SOBRINHO, 2002) - porém, mais danosa aos países menos desenvolvidos, caracterizados por ainda não terem 
construído sistemas educacionais consolidados. Nesse sentido, originam-se os altos índices de participação do setor privado no setor, a partir da forte expansão de IES e matrículas.

A presença do setor privado no setor educacional de nível superior, intensificado a partir da LDB de 1996, consolida-se em um movimento de mercantilização da educação superior' que se deu justamente pelo crescimento acentuado das IES de caráter lucrativo, e a adoção de estratégias comuns ao mercado como financeirização, oligopolização e internacionalização, construindo um terreno de concorrência e competitividade entre as instituições.

O movimento expansionista e de diversificação verificado nas últimas décadas, em especial a partir dos anos 1990, gerou a necessidade de fiscalização dessas instituições e cursos de nível superior por parte do Estado, de forma a avaliar e certificar se há comprometimento, por parte dessas IES (que, em muitos casos, se tornaram grandes empresas) com a prestação de serviços educacionais de qualidade - e qual seria a noção de qualidade em que se baseia esse comprometimento.

Diante do levantamento histórico sobre a avaliação da educação superior no Brasil, foi possível identificar que tais movimentos culminaram na diminuição do papel do Estado enquanto educador (na perspectiva de aumentar o investimento público em educação), tornando-se muito mais um avaliador ou gestor. Com relação a esse novo modelo e forma de organização do Estado, Marback Neto e Falcão (2007) apontam que

[...] nessa medida, cresceu de modo significativo a oferta de ensino superior privado, dirigido como empresa. Ao ter o lucro como perspectiva predominante, as IES privadas apresentam qualidade heterogênea, obrigando o Estado a assumir a função fiscalizadora dos estabelecimentos. Num contexto assim, instituiu-se a avaliação institucional como processo fiscalizador (MARBACK NETO e FALCÃO, 2007, p. 140)

Nessa perspectiva, a partir das décadas de 1980 e 1990, a qualidade começou a entrar em discussão na agenda de políticas da educação superior: “com a expansão do Estado avaliador, a qualidade, como seu substrato, adquire força” (MOROSINI, 2009, p. 167).

Frente a estes fatos, têm-se a discussão: se por um lado, boa parte das instituições de ensino buscou a adequação e a adaptação às novas demandas dos modelos econômicos e políticos, além de terem se originado no contexto de domínio do setor privado, por outro lado é importante que tais instituições não se transformem, e se reduzam apenas em objetos do mercado - ou seja, não percam o caráter de comprometimento relacionado ao ensino de qualidade e à difusão do conhecimento, muito embora essa discussão seja bastante complexa e 
heterogênea. Nesse sentido, torna-se importante discutir como é avaliada a qualidade educacional, em um contexto de diversificação e aumento vertiginoso de IES e cursos.

Realizada, então, uma breve retomada do contexto histórico sobre quais aspectos perpassaram e também influenciaram a emergência do tema da qualidade na educação superior no país, torna-se possível adentrar à discussão sobre a formulação e direcionamento do(s) conceito(s) de qualidade - e como estes podem ser avaliados. É importante ressaltar que qualidade na educação é um conceito multidimensional (BURLAMAQUI, 2008), ou seja, pode abranger diferentes aspectos das IES (gestão, corpo docente, processos), dos alunos (qualidade do ensino ofertado, desempenho dos alunos), dos cursos, da pesquisa e extensão, etc., em processos separados ou concomitantes, com diferentes ênfases metodológicas, correntes pedagógicas, entre outros, o que obrigatoriamente torna essa discussão extremamente complexa e impossível ser contemplada em todas as suas dimensões conceituais neste breve espaço.

Como ponto de partida para a abertura da discussão, a abordagem de Morosini (2009, p. 167) condensa alguns aspectos relevantes ao tema. Ao analisar o panorama internacional sobre qualidade educacional por meio de alguns documentos propositivos de organismos multilaterais, como a Organização das Nações Unidas para a Educação, a Ciência e a Cultura (Unesco) e a Organização para a Cooperação e Desenvolvimento Econômico (OCDE), a autora elenca três tipos de noções de qualidade da educação superior, cuja ideologia influencia modelos nacionais, inclusive a realidade brasileira - e que certamente influenciam a construção de políticas neste sentido, com a expansão do Estado avaliador, sendo aqui descritos de forma resumida:

1) A qualidade isomórfica (marcada pela tendência de uso de índices avaliativos, construindo padrões, índices, rankings, cuja característica principal é que são basicamente voltados para o mercado);

2) A qualidade da diversidade (conceito bastante disseminado pela Unesco que considera a atenção aos contextos e especificidades institucionais, nacionais e regionais, embora também possa ocorrer uma padronização de indicadores, mesmo no contexto de preservação dessas diversidades);

3) A qualidade da equidade (em que o sistema deve buscar corresponder às necessidades e potencialidades de cada indivíduo inserido no processo educativo, baseado nos 
princípios de justiça social. A qualidade ligada à equidade é um conceito amplamente utilizado para Unesco e OCDE, em que se buscam metodologias quantitativas e qualitativas para alcançar a qualidade educacional).

Diante do quadro explicitado, Morosini (2009) avalia que, no cenário mundial, entre as categorias de qualidade elencadas, as três perspectivas estão presentes nas políticas educacionais, ocorrendo uma proximidade/minimização de fronteiras entre elas no decorrer das décadas. Sobretudo, a autora ressalta que ainda é característica marcante o predomínio da noção de qualidade isomórfica, ou seja, de perspectiva quantitativa e voltada à construção de indicadores. No entanto, nas diversas categorias, continua presente o dilema de que "[...] a concepção de qualidade não é clara. Da mesma forma, também cabe esclarecer a quem ela é dirigida e por quem ela é definida" (MOROSINI, 2009, p. 183).

Bertolin (2009) reconhece que o conceito de qualidade é bastante subjetivo, e ligado a cada contexto que o formula. No entanto, assim como Morosini, também postura três noções de qualidade que identifica como mais destacadas no cenário da educação superior (entre a literatura e documentos de organismos internacionais), especialmente entre as décadas de 1990 e 2000: visão economicista, visão pluralista e visão de equidade, conforme mostra o Quadro 1.

Quadro 1 - Visões de Qualidade da Educação Superior.

\begin{tabular}{|c|c|c|c|}
\hline $\begin{array}{l}\text { Visão de } \\
\text { qualidade }\end{array}$ & Termos associados & Grupos de interesse & $\begin{array}{c}\text { Propósitos da Educação } \\
\text { Superior }\end{array}$ \\
\hline $\begin{array}{c}\text { Visão } \\
\text { economicista }\end{array}$ & $\begin{array}{l}\text { Empregabilidade e } \\
\text { Eficiência }\end{array}$ & $\begin{array}{l}\text { Setor privado, OCDE e } \\
\text { setor governamental }\end{array}$ & $\begin{array}{l}\text { Ênfase nos aspectos de } \\
\text { potencialização do } \\
\text { crescimento da economia e } \\
\text { da empregabilidade }\end{array}$ \\
\hline Visão pluralista & $\begin{array}{l}\text { Diferenciação, } \\
\text { Pertinência e } \\
\text { Relevância }\end{array}$ & $\begin{array}{l}\text { Unesco, União Europeia e } \\
\text { setor educativo }\end{array}$ & $\begin{array}{l}\text { Diversidade de aspectos } \\
\text { relevantes (economia, } \\
\text { sociocultural, democracia } \\
\text { etc.) com ênfase na } \\
\text { emergência das } \\
\text { especificidades locais }\end{array}$ \\
\hline $\begin{array}{l}\text { Visão de } \\
\text { equidade }\end{array}$ & Equidade & Unesco e setor educativo & $\begin{array}{c}\text { Ênfase nos aspectos de } \\
\text { contribuição para coesão } \\
\text { social }\end{array}$ \\
\hline
\end{tabular}

Fonte: BERTOLIN (2009, p. 134).

Entendendo que a qualidade não pode ser objeto de reflexão em separado do contexto de transformações na educação superior e do jogo de interesses envolvidos, Bertolin (2009) 
relaciona a visão economicista da qualidade aos princípios do neoliberalismo, crescimento econômico e ênfase na formação para o mercado de trabalho, além de uma racionalização dos processos institucionais visando a contenção de custos e maior rapidez no alcance dos objetivos, especialmente com o uso do termo eficiência, que possui maior familiaridade com o contexto da administração e da gestão.

A visão pluralista da qualidade relaciona-se com o as diversidades contidas em uma sociedade, no que tange aos aspectos econômicos, sociais, culturais, regionais, etc., cujos princípios são difundidos inclusive pela Unesco e União Europeia. O autor explicita que, nessa visão, são extrapoladas as questões econômicas, visando outras dimensões como “desenvolvimentos cultural, social e democrático de forma sustentável e equilibrada dos países e sociedades, também são considerados importantes para os propósitos da educação superior" (BERTOLIN, 2009, p. 138).

Por fim, a última noção de qualidade elencada é a visão de equidade, também relacionada aos documentos e propósitos da Unesco, visando a diminuição da desigualdade de oportunidades, que refletem nas mais diversas instâncias (aspectos de raça/cor, sexo, étnicos, religiosos, culturais, econômicos, etc.), em um contexto educacional em que

Diversas avaliações e medições da educação em vários países constatam a permanência de enormes diferenças de resultados entre distintas escolas e regiões. [...] Dessa forma, como a educação continua sendo, indiscutivelmente, um dos principais meios de mobilidade social, faz-se necessário buscar a equidade educacional. Num contexto de grave exclusão social, como no caso da América Latina, a emergência do combate às iniquidades educacionais aparece de forma mais contundente (BERTOLIN, 2009, p. 142).

A questão da equidade também é muito importante para Mora Alfaro (2005), que afirma que a qualidade da educação, em todos os níveis, possui estreita relação com a noção de equidade. É percebido, para o autor, um profundo estado de desigualdade na sociedade (a América Latina é o enfoque de seu estudo), em que grupos com maior poder aquisitivo conseguem avançar em maiores níveis educacionais em relação aos que são desfavorecidos. Nesse contexto, encontra-se uma disparidade em relação à qualidade da educação, que normalmente é maior em instituições nas quais a população com maior renda possui acesso. Portanto, a melhoria da qualidade se torna um aspecto essencial para superação de desigualdades e promover mobilidade social, em busca de um desenvolvimento includente para 
os países: "invertir en el aseguramiento de la calidad de la educación superior significa invetir em desarollo y en equidad" (MORA ALFARO, 2005, p. 128).

Outro debate sobre a qualidade é apresentado por Dias Sobrinho e Dias (2006, p. 18), entendendo-a em um contexto que é "histórica e social, por isso, complexa, contraditória e inescapavelmente dinâmica". No entanto, os autores afirmam que as mudanças relacionadas à globalização econômica impõem uma lógica em que "qualidade seria um conceito objetivamente identificável e livre de contextos específicos e idiossincrasias" (DIAS SOBRINHO e DIAS, 2006, p. 11). Ou seja, na mesma linha do que é abordado por Morosini (2009), os autores também identificam a presença de uma tendência forte de padronização e possibilidade de medição, comparação e classificação em torno do conceito de qualidade da educação superior, muitas vezes fruto de critérios internacionais, estabelecidos por organismos multilaterais com integração em agências e organismos nacionais e locais. Para os autores,

[...] o conceito de qualidade em educação superior tende a se adaptar às exigências do mundo econômico e a seus códigos morais e ideológicos. Individualismo, individualismo possessivo, liberdade individual, livre escolha, sucesso pessoal, competitividade, lucro, empreendedorismo, eficiência, excelência, produtividade, rendimento, resultados são expressões fortemente indicativas da noção de qualidade (DIAS SOBRINHO e DIAS, 2006, p. 12)

Sguissardi (2006) também se debruçou sobre o tema, mas sem a proposta de encontrar uma definição única ou precisa. Realizando uma análise do panorama mundial, o autor recupera o histórico da construção das diferentes noções de qualidade envolvidas na educação superior, sustentando que esse conceito é influenciado por diversos fatores, como o contexto econômico e político de reestruturação produtiva, mundialização do capital, mudanças no campo ideológico e redesenho político-econômico global.

$\mathrm{O}$ autor afirma que, no Brasil, "a qualidade no ensino, na pesquisa, no fazer universitário, não é algo novo nem alheio à vida universitária, nunca tendo deixado de ser objeto de cuidados, em especial das boas universidades através do tempo" (SGUISSARDI, 2006, p. 70-71), ligando, portanto, esse conceito à "excelência acadêmico-científica" (SGUISSARDI, 2006, p. 84). No entanto, face às transformações ocorridas nas últimas décadas, a qualidade da educação superior tem sido associada ao Estado avaliador - que, conforme observado na seção anterior, surge a partir da emergência de processos de avaliação frente à expansão e diversificação das instituições de ensino superior. Além disso, assim como para outros autores citados nesta seção, há também a identificação de conceitos como competitividade e 
empregabilidade relacionados à questão da qualidade, ligados à lógica do mercado e das políticas econômicas vigentes. Sguissardi também afirma que o papel da qualidade tem sido pouco significativo nas políticas de educação superior no país, visivelmente em torno do baixo investimento no setor público, entre outros aspectos.

$\mathrm{Na}$ impossibilidade de abranger todas as dimensões da discussão conceitual acerca do tema da qualidade, a opção foi de resgatar algumas das principais discussões no âmbito da educação superior. Contudo, é possível perceber que, conforme expõe Sguissardi (2006), qualidade e avaliação são hoje temas extremamente discutidos no campo da educação superior, sobretudo na forma do Estado avaliador; entretanto, são conceitos de imensa complexidade e que possuem significados diferentes conforme o contexto.

Partindo da premissa que estes temas estão estreitamente ligados, na próxima seção o objetivo é tratar do debate sobre a questão da qualidade nas políticas de avaliação da educação superior, especificamente no caso brasileiro, considerando a discussão previamente realizada em torno desses dois temas.

\subsubsection{O debate sobre Qualidade e Avaliação da educação superior no Brasil: limites e possibilidades}

Qualidade e avaliação são termos ligados de forma intrínseca na educação, inclusive na superior, já que o foco central da avaliação é a busca da qualidade (DIAS SOBRINHO, 2008b). Além disso, não é possível entender as tendências da educação superior sem considerar as práticas da avaliação, considerando que há uma relação estreita entre a avaliação e as políticas transformadoras dos sistemas de educação superior (DIAS SOBRINHO, 2002). Entretanto, nesta relação intrínseca que se constitui na construção de metodologias de avaliação e indicadores de qualidade, encontra-se um processo corrente e em transformação na agenda brasileira. Conforme detalhado anteriormente, a história ${ }^{37}$ de constituição dos processos de avaliação no país é marcada por diversos debates, principalmente em torno da própria concepção de avaliação a ser empregada, e sobre que instância deve ser responsável por realizála, sendo esta uma discussão diversificada de acordo com os interesses dos grupos e dos atores políticos, econômicos e sociais envolvidos.

\footnotetext{
${ }^{37}$ Conforme consta na seção 1.2 deste Capítulo: Histórico da Avaliação da Educação Superior no Brasil.
} 
Além disso, sabe-se que a avaliação na educação pode ser compreendida numa imensa gama de aspectos, que envolvem não apenas as dimensões do ensino, mas também de gestão, gerenciamento, condições sociais e econômicas, diversidade de modelos de instituição superior, entre outros. Alguns destes muitos aspectos podem ser elencados como relativos à qualidade do ensino (em diversas vertentes): da gestão, do gerenciamento, do projeto pedagógico institucional, da infraestrutura (adequação e aparelhamento - bibliotecas e laboratórios, por exemplo), do grau de autonomia da comunidade acadêmica, corpo de professores, incentivo à pesquisa e extensão, participação e convênio com projetos, entre outros.

A avaliação da educação superior, que somente na década de 1980 passou a ter maior destaque na agenda política brasileira, trouxe consigo a emergência da busca pela qualidade, tornando-se este também um tema central na agenda da educação superior. Conforme afirma Morosini (2009, p. 167), "no final dos anos 80 e na década de 90, foi registrado o desvirtuamento da concepção de qualidade, como um conjunto de fases, com predominância de uma delas: a da avaliação".

Sguissardi (2006), na mesma linha, verifica que uma das fortes tendências da educação superior nesse período é associar, frequentemente, a questão da qualidade ao Estado avaliador, ou seja, à instituição de processos de avaliação e controle da qualidade, inclusive traduzindo-se em estratégias de nível nacional ou supranacional nesse sentido. Esse movimento de atrelar à discussão da qualidade ao aspecto da avaliação não aparece somente no cenário brasileiro, mas em decorrência da globalização da economia, "é no contexto da internacionalização da educação superior que se dá a reestruturação do sistema e o implemento da avaliação e do controle da qualidade" (SGUISSARDI, 2006, p. 76).

Surgem no mesmo âmbito discussões sobre as questões de garantia pública da qualidade, certificação e acreditação ${ }^{38}$, mecanismos de controle da qualidade visando a construção de padrões e comparações. Ou seja, em um contexto de forte expansão quantitativa da educação superior, diferentes atores (Estado, sociedade e mercado) atuam no controle do sistema (DIAS SOBRINHO, 2008a), em que essas práticas de fiscalização da qualidade acabam ligadas às doutrinas do pensamento econômico dominante, em especial de organismos que têm

\footnotetext{
${ }^{38}$ A acreditação pode ser caracterizada como uma prática que visa garantir a qualidade dos cursos superiores: "acreditar é praticar um ato legal certificando que uma instituição, um curso, um programa tem qualidade; portanto, seus efeitos são legítimos e publicamente assegurados e validados pelo Estado" (DIAS SOBRINHO, 2008a, p. 818). A acreditação está envolvida em um contexto formal que envolve alcançar resultados baseados em padrões previamente estabelecidos, geralmente por agências externas, ligadas a entidades internacionais e ao predomínio dos moldes econômicos globais.
} 
forte atuação nesse contexto, como os já citados Unesco, OCDE, União Europeia e Banco Mundial.

Essa perspectiva está relacionada, ainda segundo Dias Sobrinho (2008a), à noção de qualidade atrelada às práticas vigentes, de quem as define e para quem - principalmente oriunda de uma expectativa de grupos dominantes na sociedade. A agenda neoliberal, embora não sendo responsável pela explicação da totalidade do processo, contribuiu de forma bastante relevante, devido a recomendação de adoção de sistemas educacionais baseados em conceitos de eficiência dos processos e eficácia técnica dos resultados, adequados ao novo modelo econômico, para os quais a avaliação institucional demonstrou ser uma ferramenta necessária e imprescindível; a OCDE, por exemplo, entende a avaliação como importante para oferecer informações sobre a eficácia e a eficiência das políticas públicas educacionais de cada país. Com relação aos aspectos metodológicos, para consolidar bases possíveis de serem comparadas mundialmente, tornou-se essencial que essas informações fossem basicamente quantitativas (DIAS SOBRINHO, 2002).

A qualidade da educação, também no contexto brasileiro, passou a ser um objeto de interesse para os grupos dominantes da economia e da política, "entre outras razões porque a ciência-tecnologia tornou-se mercadoria-chave, ao lado do trabalho, da acumulação do capital" (SGUISSARDI, 2006, p. 73). A qualidade, agora intrinsecamente ligada às ferramentas de avaliação, passou a ser reduzida a algo objetivo e mensurável por meio do uso de métodos quantitativos:

Como tendência geral, se observa que, quando a avaliação e o conceito de qualidade estão determinados pelos especialistas externos e as autoridades governamentais, em geral, se limitam a controlar, medir, certificar e regular, em detrimento dos processos participativos e formativos de reflexão e debates da comunidade acadêmica e científica, com prejuízo, portanto, ao exercício da autonomia universitária (DIAS SOBRINHO, 2008a, p. 819).

Sguissardi (2006) aponta que nas políticas pioneiras de avaliação da educação superior no Brasil, o PAIUB (a partir de 1993-1994) e o Exame Nacional de Cursos (a partir de 1996), foram destacados movimentos em torno da busca pela qualidade nesse nível educacional - não sem terem gerado diversos questionamentos em torno de suas concepções e operacionalizações. 
Sendo uma responsabilidade do Estado assegurar educação de qualidade a todos e em todos os níveis, conforme assinalado na Constituição Federal de $1988^{39}$, os documentos oficiais de políticas educacionais procuram deixar claro uma relação direta entre instrumentos de avaliação e qualidade da educação superior. A expansão do sistema, em torno do aumento das matrículas e diversificação institucional e dos cursos de graduação, também reforçou a necessidade de avaliação e controle, de alguma maneira, da qualidade desse nível.

Entre estes documentos oficiais, é possível citar os Planos Nacionais de Educação (PNEs), conhecidos por estabelecer as principais prioridades e metas com relação à educação, em que no PNE de 2001-2010 se destacou a necessidade de institucionalização de um amplo e diversificado sistema de avaliação interna e externa dos setores público e privado de educação superior, para promover a melhoria da qualidade do ensino, da pesquisa, da extensão e da gestão acadêmica.

Nesse sentido, buscando aproximar-se da realização das metas do PNE, e aperfeiçoando os mecanismos de avaliação que foram objetos de tentativa nos momentos anteriores, como o PAIUB e o ENC, foi criado em 2004 e configura-se como a atual experiência de avaliação superior o SINAES, em que uma de suas finalidades é a melhoria da qualidade da educação superior, por meio de um sistema de avaliação que integra três fases: avaliação das Instituições de Ensino Superior; avaliação dos cursos superiores de graduação; e avaliação do desempenho dos estudantes dos cursos de graduação ${ }^{40}$.

No entanto, é possível perceber que com o SINAES, apesar de ser constituído por mecanismos diversificados de avaliação para considerar essas diferentes dimensões, entre eles o uso de avaliação institucional interna e externa, ficou marcada, sobretudo, a tendência de ênfase nos métodos quantitativos para avaliar a qualidade da educação superior. Baseando-se nos três eixos principais de avaliação do sistema, foram adotados três indicadores de qualidade da educação superior: o Índice Geral de Cursos (IGC) para as instituições, o Conceito Preliminar de Curso (CPC) para os cursos e o Conceito ENADE, que avalia o desempenho dos estudantes a partir dos resultados do Exame Nacional de Desempenho dos Estudantes.

A ampla utilização desses resultados - divulgados em forma de escala numérica - tanto pelo sistema educacional como pelos órgãos da mídia favoreceu a criação de rankings e um ambiente de competitividade entre as instituições de ensino, tornando estes números

\footnotetext{
${ }^{39}$ Conforme o Capítulo III - "Da Educação, da Cultura e do Desporto", Art. 206: "O ensino será ministrado com base nos seguintes princípios: [...] VII - garantia de padrão de qualidade” (BRASIL, 1999).

${ }^{40}$ Conforme tratado anteriormente na seção 1.3 - O Sistema Nacional de Avaliação da Educação Superior (SINAES).
} 
praticamente o reflexo do que é qualidade de uma instituição, um curso ou do desempenho dos alunos. Assim,

\begin{abstract}
Não obstante o conceito de qualidade em educação superior possuir elevado grau de subjetividade [...] o emprego em larga escala de exames na avaliação dos estudantes da graduação se tornou uma questão crítica para a percepção da sociedade sobre o valor e a qualidade das instituições e cursos (BERTOLIN e MARCON, 2015, p. 108).
\end{abstract}

Nesse contexto, o paradigma de avaliação acabou se tornando mais quantitativo, com foco no controle e na classificação, deixando de lado os diversos outros eixos e princípios norteadores de uma abordagem mais qualitativa, de reflexão dos processos.

No entanto, o uso de indicadores, ou mesmo de um sistema de indicadores têm sido amplamente enfatizado e utilizado para analisar o desenvolvimento, o desempenho e a qualidade dos sistemas nacionais de educação (BERTOLIN, 2007); ainda que, para o autor, a qualidade da educação superior deva ser considerada um conceito múltiplo, não podendo ser avaliada por apenas um indicador isolado. Para Bertolin e Marcon (2015, p. 119), "não há dúvida de que avaliar cursos e instituições da educação superior, inclusive por meio de exames aplicados aos estudantes como um dos instrumentos de um sistema mais amplo, é importante", no entanto, há uma percepção crítica em torno de se tornarem automaticamente sinônimos de qualidade da educação superior.

Para Oliveira (2011), torna-se necessária a construção de indicadores de qualidade consistentes, que possam auxiliar na formulação de políticas públicas, inclusive para que seja possível atenuar questões de desigualdade em âmbito nacional (não apenas questões locais ou isoladas). Porém, para o autor, é preciso aprofundar a discussão sobre o que se entende sobre qualidade, e qual seria um indicador de qualidade adequado à realidade do país, sobretudo um indicador que seja passível de ser concretizado.

De fato, no que tange à qualidade, os processos de avaliação e acreditação são de grande importância face à expansão desenfreada da educação superior privada brasileira, gerada no bojo do atendimento aos interesses do mercado. Sem dúvidas, é preciso haver certo controle e regulação para assegurar que as instituições da área educativa cumpram suas responsabilidades e funções sociais, dado que

Seja na modalidade de auto-avaliação institucional ou de exames voltados para quantificação dos resultados da aprendizagem de estudantes, a avaliação torna-se a medida de qualidade do ensino, da pesquisa, da extensão e da gestão 
acadêmica nas instituições de ensino, além de se constituir em um dos instrumentos utilizados para administrar o sistema nacional de ensino superior e em um dos critérios para a definição das regras do financiamento institucional (OLIVEIRA, FONSECA e AMARAL, 2006, p. 76).

Neste sentido, é importante discutir a avaliação não apenas em seus processos e instrumentos, mas em torno da construção do próprio conceito de avaliação enquanto polissêmico (assim como o conceito de qualidade) e o contexto em que se insere, bem como os interesses envolvidos. No processo avaliativo encontram-se em jogo movimentos recíprocos de troca de informações e influências, entre o campo institucional e o campo educacional. O que está em jogo é que "a avaliação é um processo que não pode resolver, imediatamente, os problemas macroestruturais, embora seja capaz de contribuir nessa direção" (MARBACK NETO e FALCÃO, 2007, p. 143). Também ressaltando aspecto semelhante, Oliveira, Fonseca e Amaral (2006) afirmam que a avaliação das instituições de ensino superior ainda possui muitos desafios a serem superados para que seus instrumentos atinjam os objetivos proclamados, no sentido de provocar mudanças qualitativas no âmbito educacional.

Apesar da problemática envolvida, considera-se que a avaliação é necessária, pois além de filtrar a complexa e diversificada rede educacional (especialmente em um país extremamente heterogêneo em termos econômicos, sociais e regionais como o Brasil), promove uma maior capacidade de organização do sistema, ao passo que se constitui como um processo de construção de juízos de valores para tomadas de decisões, constituindo um espaço e um processo indispensável na perspectiva da melhoria da qualidade de todos os aspectos relativos às atividades de ensino.

A questão, portanto, parece não girar em torno da necessidade de avaliação da qualidade, o que se constitui como uma realidade; mas sim, da metodologia empregada em torno do processo de avaliação, seus riscos e vantagens: o peso dos elementos quantitativos nos instrumentos utilizados para a avaliação da educação superior, tal como existem hoje, acabam por relegar suas funções ligadas à esfera educativa, dedicada à construção de autonomia para os indivíduos e de formas mais democráticas e críticas de integração com a sociedade, para tornarem-se instrumentos cujo papel é estritamente de controle, regulação, quantificação, que estimulam a heterogeneidade e a competitividade - tanto dos indivíduos, como das instituições de ensino. A qualidade da educação passa do âmbito de desenvolvimento humano e social, para desenvolvimento técnico e econômico, correspondendo a conceitos como a eficácia e a eficiência - envolvendo a diminuição de gastos, aumento de produtividade, otimização de processos e busca de resultados. 
Certamente, como foi observado, qualidade e avaliação são conceitos que estão estreitamente ligados, possuindo imensa complexidade e difíceis consensos. Por outro lado, entende-se com o levantamento bibliográfico que seu caráter polissêmico não pode ser utilizado como pretexto para fugir da discussão em torno de seus significados, processos de construção e aplicação. Para além das críticas, é necessário pensar como esses processos vigentes podem ser modificados e transformados. Entender quais elementos seriam importantes para um modelo de avaliação e construção de indicadores para medir a qualidade mais coerentes com a esfera educativa é um processo de grande dificuldade, que envolve refletir sobre questões chave como: que perspectiva de educação? Para quem? Como realizá-la? Além do exercício de reflexão sobre conceitos como: autonomia, justiça, igualdade, equidade, diversidade, entre outros.

A crítica de Dias Sobrinho (2008a) indica que, embora a avaliação seja necessária, para que se alcance a qualidade na educação, ela

[...] deve ir além das medidas de conformação: deve ser uma política pública que contribua para o aprofundamento dos valores democráticos; portanto, deve valorizar as políticas de democratização do acesso e condições de permanência, a equidade, a construção e socialização dos conhecimentos como bem público, a associação da função cognitiva com a função formativa integral do profissional social (DIAS SOBRINHO, 2008a, p. 824)

Para o autor, essas concepções devem estar sempre vinculadas a uma reflexão mais ampla da sociedade e do desenvolvimento humano. A perspectiva sócio-política-crítica (DIAS SOBRINHO, 2002) é uma alternativa que concebe as instituições educativas (no caso, o modelo de universidade a ser buscado) como instituições sociais e políticas que investigam sobre sentidos e valores, com atividade de construção, não apenas de reprodução do conhecimento. Fundamenta-se em valores como a consciência crítica, a ética e a cidadania; a solidariedade; a justiça, a igualdade e os direitos civis. Na perspectiva mais específica do plano pedagógico, baseia-se em ações formativas, que educam e socializam para formar profissionais conscientes e transformadores da história. A qualidade em educação, para o autor, é ligada essencialmente à formação e aos valores comuns à humanidade, já expostos anteriormente. Todos esses elementos seriam opostos à perspectiva ligada ao mercado, negando a lógica cientificista, tecnicista, economicista e individualista presente no setor educacional atual.

Em síntese, por meio das discussões levantadas, foi possível entender um pouco da complexidade e da relevância da discussão sobre qualidade e avaliação na educação superior. Ao tratar estes temas parece necessário, como exercício primeiro, não buscar conclusões imediatas, mas sim questionamentos - pensando sempre na vasta gama de referências, 
pluralidades, múltiplos sentidos e jogos de poder que envolvem estes conceitos, como muitos outros que estão em jogo nas dimensões social, política e econômica:

Que conceitos de qualidade estão sendo trabalhados? Que modelos de avaliação? E de que maneira a avaliação se relaciona à busca pela qualidade? A quem se destinam estes conceitos? Quem os formula, em que contexto de grupos de poder? Quais as contradições em jogo para a origem desses conceitos? Quão democráticos e qual a ética envolvida nestes processos? Esses padrões levam em conta a diversidade de dimensões educacionais, como instituições, cursos, gestão, graus de autonomia acadêmica, regiões geográficas, áreas de ensino, diferentes tipos de formação e conhecimentos, entre outros? Estas são muitas das questões, entre tantas outras que podem ser agregadas, em que se torna um exercício válido a reflexão sobre elas como ponto de partida para que seja possível realizar a discussão destes temas. 


\section{CAPÍTULO 2 - O PROGRAMA UNIVERSIDADE PARA TODOS (PROUNI)}

Neste Capítulo é apresentado o tema central da dissertação, a política do Programa Universidade para Todos (ProUni), visando compreender seu funcionamento, operacionalização e os principais debates realizados da literatura relacionada ao tema. Também é realizada uma análise de dados sobre a abrangência do ProUni, envolvendo informações sobre: número de bolsas ofertadas, perfil dos bolsistas, regiões geográficas, instituições de ensino superior e cursos participantes.

\subsection{O funcionamento do ProUni}

O Programa Universidade para Todos (ProUni) é uma política educacional desencadeada pelo Governo Federal, durante o primeiro mandato do ex-presidente Luiz Inácio Lula da Silva. Foi criada em 2004, institucionalizada pela Medida Provisória n ${ }^{\circ} 213$, de 10 de setembro de 2004, implementada pela Lei ${ }^{\circ} 11.096$, de 13 de janeiro de 2005 e regulamentada pelo Decreto $\mathrm{n}^{\circ}$ 5.493, de 18 de julho de 2005, com a premissa de democratizar o acesso ao ensino de nível superior. A política objetiva a concessão de bolsas de estudos integrais (100\%) e parciais (50\% ou 25\%) a estudantes de cursos de graduação e sequenciais de formação específica, em Instituições de Ensino Superior privadas (com ou sem fins lucrativos) em todo o território nacional. Segundo dados oficiais do MEC (BRASIL, 2015h), desde seu início, até 2014, o ProUni atendeu mais de 1,4 milhão de estudantes em cursos de graduação, com 70\% de bolsas integrais.

O público alvo do Programa são estudantes egressos do ensino médio da rede pública de ensino. Também podem pleitear bolsas alunos na rede particular, desde que tenham cursado todo o período com o auxílio de bolsa de estudos integral. Além disso, há um critério complementar de seleção baseado na renda: o candidato precisa ter uma renda bruta mensal per capita de seu grupo familiar de até um salário mínimo e meio, para requerer bolsas integrais; e de até três salários mínimos para requerer bolsas parciais. O modo de seleção, de caráter classificatório, configura-se a partir do desempenho dos estudantes no Exame Nacional do Ensino Médio (ENEM) do ano imediatamente anterior ao do processo seletivo, em que o candidato precisa ter alcançado, no mínimo, 450 pontos na média das notas das diversas provas do ENEM e nota acima de zero na redação. O estudante não pode aderir ao Programa caso já tenha se formado em algum curso de nível superior. O Programa também possui reserva de 
bolsas por raça/cor (indígenas, pardos e pretos), para pessoas com deficiência e para a adesão de professores da rede pública de ensino, desde que estejam em exercício do magistério da educação básica (estes últimos, para concorrer a bolsas em cursos de licenciatura).

O processo seletivo do ProUni se dá a partir da internet, por meio de inscrição online, duas vezes ao ano (dois semestres) para seleção de bolsas regulares. São regidos por Portarias Normativas que saem também semestralmente, antecedendo cada processo seletivo. As inscrições ficam abertas por poucos dias, geralmente, uma semana; após este período, também há uma seleção para bolsas remanescentes. Para o processo regular, o estudante cadastra seus dados, insere sua nota média do ENEM e pode selecionar até duas opções de Instituição de Ensino Superior, curso, turno e tipo de bolsa. Caso seja portador de deficiência ou autodeclarado indígena, pardo ou preto, o estudante pode optar pelas bolsas destinadas às ações afirmativas, já reservadas para estes critérios. Cabe ressaltar que a escolha das duas opções pelo candidato é pautada por diversos filtros e não apenas por cursos - então, em uma situação hipotética de um estudante que quer cursar Direito, se este escolher dois turnos do mesmo curso (matutino e noturno), já terá esgotado suas opções pelo sistema. O número de opções para escolha foi sendo reduzido com o tempo - eram cinco opções até 2011 (BRASIL, 2011a), quando passaram para três, até chegar às duas opções de 2012 em diante (BRASIL, 2012d). Nota-se, então uma redução, ao longo do tempo, do leque de oportunidades que os candidatos possuem. Um ponto positivo é que, após alguns dias da abertura do processo seletivo, é possível visualizar uma média preliminar das notas de corte de outros candidatos que escolheram a mesma opção de curso, visando facilitar as escolhas mais próximas da nota que o estudante obteve, podendo este trocar as opções feitas durante todo o período de inscrições.

Após a classificação dos estudantes, é realizado um processo de chamada (também via internet), para a comprovação das informações socioeconômicas prestadas, de acordo com o tipo de bolsa pleiteada (integral ou parcial), tais como: histórico escolar, comprovantes de renda do grupo familiar e do estudante, entre outros. Essa comprovação é feita já na instituição de ensino escolhida pelo participante, pelo coordenador do ProUni correspondente. Na Portaria Normativa MEC $\mathrm{n}^{\circ} 1 / 2015$, que regulamenta os processos seletivos no determinado ano, é disposto que o coordenador pode, facultativamente, solicitar “[...] quaisquer outros documentos que [...] eventualmente julgar necessários à comprovação das informações prestadas pelo estudante, referentes a este ou aos membros de seu grupo familiar” (BRASIL, 2015i, Art. 18). Na Lei do ProUni, é descrito que o estudante é, “[...] na etapa final, selecionado pela instituição de ensino superior, segundo seus próprios critérios, à qual competirá, também, aferir as 
informações prestadas pelo candidato" (BRASIL, 2005a, Art. $3^{\circ}$ ). Aqui cabe destacar que o entendimento sobre o grupo familiar é definido como "unidade nuclear composta por uma ou mais pessoas, eventualmente ampliada por outras pessoas que contribuam para o rendimento ou tenham suas despesas atendidas por aquela unidade familiar, todas moradoras em um mesmo domicílio" (BRASIL, 2015i, Art. 11). Todavia, o processo de aceitação ou não do estudante acaba ficando a critério de cada instituição, que inclusive, possui liberdade para acionar outro processo seletivo para a entrada do candidato, como uma prova, por exemplo: "É facultado às IES [...] definirem local e horário para a aferição das informações prestadas pelos estudantes pré-selecionados, bem como para a aplicação de eventual processo próprio de seleção" (BRASIL, 2015i, Art. 14, § $1^{\circ}$ ). Também é determinado que essas instituições informem aos estudantes, em tempo hábil, a natureza e os critérios de aprovação, os quais não poderão ser mais rigorosos do que os aplicados aos estudantes regulares da instituição.

Diante deste quadro, o que se observa é que o processo seletivo é extremamente diferente de uma instituição para outra; algumas pouco exigentes em relação à documentação, e outras que dificultam a entrada de um aluno pré-selecionado pelo ProUni. Inclusive, “o MEC não realiza fiscalizações in loco nas IES participantes, que possuem liberdade para atuarem da forma que mais lhes interessar" (BRASIL, 2009a, p. 9).

O processo de aprovação ou reprovação dos candidatos é registrado pelas instituições no Sistema Informatizado do ProUni (SisProUni). Após a aprovação, a manutenção da bolsa do ProUni pelo estudante fica condicionada ao cumprimento de bom desempenho acadêmico, e frequência mínima obrigatória de $75 \%$ da carga horária do curso, em cada período letivo, ou pode ter sua bolsa encerrada. A instituição de ensino também possui liberdade para conduzir os processos de renovação de bolsa: algumas exigem documentos semestralmente e/ou anualmente, buscando comprovar a renda, e outras não exigem a renovação de documentos até a finalização do curso, permitindo aos bolsistas apenas assinar um termo de renovação. A exigência de comprovação da renda que atenda aos padrões do Programa, de forma constante, pode limitar o desenvolvimento socioeconômico dos estudantes, como por exemplo, começar a trabalhar ou mudar de emprego (COSTA, 2008; ALMEIDA, 2012).

O ProUni também oferece algumas alternativas de permanência aos estudantes, como a Bolsa Permanência, que concede um auxílio aos bolsistas que estejam matriculados em cursos de período integral. Esse valor inicialmente era de R \$300,00 e vigorou até 2011. Após esse 
período, passou a ser baseado nos valores das bolsas nacionais de Iniciação Científica ${ }^{41}$, conforme a Lei ${ }^{\circ} 11.180$, de 23 de setembro de 2005. Há também convênios de estágio com a Caixa Econômica Federal (CEF), e o bolsista pode utilizar o Fundo de Financiamento Estudantil (Fies), concomitantemente ao ProUni ${ }^{42}$ no caso de bolsa parcial, se desejar financiar o restante das mensalidades do curso.

As Instituições de Ensino Superior com fins lucrativos ou sem fins lucrativos não beneficentes ${ }^{43}$ podem aderir ao ProUni por meio de um termo de adesão. Elas se comprometem a oferecer no mínimo,

[...] 1 bolsa integral para o equivalente a 10,7 estudantes regularmente pagantes e devidamente matriculados ao final do correspondente período letivo anterior, [...] ou poderá, alternativamente, [...], oferecer 1 bolsa integral para cada 22 estudantes regularmente pagantes e devidamente matriculados em cursos efetivamente nela instalados, [...], desde que ofereça, adicionalmente, quantidade de bolsas parciais de $50 \%$ ou de $25 \%$ na proporção necessária para que a soma dos benefícios concedidos na forma desta Lei atinja o equivalente a $8,5 \%$ da receita anual dos períodos letivos que já têm bolsistas do ProUni, [...] em cursos de graduação ou seqüencial de formação específica. (BRASIL, 2005c, Art. 5)

No mesmo contexto, as IES beneficentes de assistência social ${ }^{44}$ deverão oferecer, obrigatoriamente, 1 bolsa de estudo integral a cada 9 estudantes regularmente pagantes. O termo de adesão possui duração de 10 anos e é renovável por igual período. Além da distribuição por curso, turno e unidade, deve haver percentual de bolsas reservadas para portadores de deficiência ou para pessoas autodeclaradas indígenas, pardas e pretas, em que a Lei define que o percentual de reserva deve ser “[...] no mínimo, igual ao percentual de cidadãos autodeclarados indígenas, pardos ou pretos, na respectiva unidade da Federação, segundo o

41 Corresponde ao valor de $\mathrm{R} \$ 400,00$ em janeiro de 2016, de acordo com o Conselho Nacional de Desenvolvimento Científico e Tecnológico (CNPq).

${ }^{42}$ Somente é permitido o financiamento do Fies, pelo bolsista do ProUni, no mesmo curso e mesma instituição de ensino (BRASIL, 2014b).

${ }^{43}$ As IES sem fins lucrativos podem ser classificadas em comunitárias, confessionais e filantrópicas, de acordo com o Art. 20 da LDB (BRASIL, 1996), possuindo imunidade tributária sobre o patrimônio, renda e serviços.

${ }^{44}$ As IES também podem ser entidades beneficentes de assistência social, que são instituições privadas certificadas pelo Governo Federal e possuem isenção de contribuições sociais, prioridade na celebração de convênios com o poder público, entre outros benefícios (BRASIL, 2016e).

Segundo a Lei do ProUni, para que as IES sejam consideradas entidades beneficentes de assistência social, devem obrigatoriamente oferecer bolsas de estudo: "A instituição de ensino superior, ainda que atue no ensino básico ou em área distinta da educação, somente poderá ser considerada entidade beneficente de assistência social se oferecer, no mínimo, 1 bolsa de estudo integral para estudante de curso de graduação ou seqüencial de formação específica [...] para cada 9 estudantes pagantes [...] regulares da instituição, matriculados em cursos efetivamente instalados, e atender às demais exigências legais” (BRASIL, 2005a, Art. $10^{\circ}$ ). 
último censo da Fundação Instituto Brasileiro de Geografia e Estatística - IBGE” (BRASIL, 2005a, Art. $\left.7^{\circ} \S 1^{\circ}\right)$.

As IES que aderem ao Programa recebem, em contrapartida, a isenção de impostos e contribuições no período de vigência do termo de adesão. As isenções atingem o Imposto de Renda das Pessoas Jurídicas (IRPJ), a Contribuição Social sobre o Lucro Líquido (CSLL), a Contribuição Social para o Financiamento da Seguridade Social (COFINS), e a Contribuição para o Programa de Integração Social (PIS), todos incidentes ${ }^{45}$ sobre a prestação de serviços destas instituições. A isenção é calculada na proporção da ocupação efetiva de bolsas devidas na assinatura do termo (BRASIL, 2005a, Art. $8^{\circ} \S 3^{\circ}$ ) - vale ressaltar que essa condição foi acrescentada somente em momento posterior à criação do Programa, pela Lei $n^{\circ} 12.431 / 2011$; inicialmente, não havia nenhuma exigência em relação à efetiva ocupação das bolsas (a isenção era a mesma para todas as IES).

O ProUni também possui determinações, em sua legislação, sobre a avaliação dos cursos participantes, em que alguns requisitos de qualidade são exigidos desses cursos, para que seja possível oferecer bolsas de estudo. A Lei determina que o MEC pode desvincular do ProUni o “curso considerado insuficiente, sem prejuízo do estudante já matriculado, segundo os critérios de desempenho do Sistema Nacional de Avaliação da Educação Superior - SINAES, por duas avaliações consecutivas” (BRASIL, 2005a, Art. $\left.7^{\circ}, \S 4^{\circ}\right)$. Esta questão, que está na centralidade da pesquisa aqui realizada, será aprofundada no Capítulo 3.

Na seção seguinte, será realizada uma revisão bibliográfica sobre o debate na educação superior em torno do Programa Universidade para Todos.

\subsection{O debate em torno da política do ProUni}

Após a implementação do Programa Universidade para Todos, em 2005, começaram a surgir debates a seu respeito, em especial no meio acadêmico. Os debates giram em torno de temas como a democratização do acesso, a inclusão e mobilidade social que a política traz como

\footnotetext{
45 Todos os impostos citados são contribuições federais (recolhidos para a Receita Federal). O IRPJ incide sobre a arrecadação das empresas; a base de cálculo, apuração e recolhimento variam conforme a opção de tributação (lucro real, presumido ou arbitrado), que pode ser trimestral ou mensal. A CSLL também é definida pela opção de tributação e o prazo de recolhimento é o mesmo do IRPJ. No caso do PIS, a contribuição é apurada mensalmente sobre o valor do faturamento mensal de empresas privadas, públicas e de economia mista ou da folha de pagamento das entidades sem fins lucrativos, cuja alíquota vai de $0,65 \%$ a $1,65 \%$; o prazo de recolhimento é até o último dia útil da quinzena do mês seguinte. A COFINS incide sobre o faturamento mensal das empresas, sendo sua periodicidade mensal e alíquotas que variam de 3\% a 7,6\%. O prazo de recolhimento é o mesmo da contribuição para o PIS. (BRASIL, 2016f).
} 
premissas; a polêmica questão da isenção fiscal que é concedida às instituições de ensino participantes, e o consequente fortalecimento do setor privado em detrimento do setor público. Encontram-se, também, críticas à vulnerável permanência do aluno bolsista nas instituições, e à qualidade questionável das instituições participantes, bem como dos cursos que são oferecidos.

As reflexões mais comuns sobre o tema ProUni são baseadas nos seguintes questionamentos: se a política possui um viés mais democratizante, ao facilitar o acesso de camadas menos favorecidas à educação superior, e/ou se é um mero instrumento de estímulo (e colaboração) a já desenfreada expansão das IES privadas, processo que ocorre de forma mais explícita desde a década de 1990 - promovendo, então, o acesso à educação de nível superior, porém isentando a obrigação de custeio direto por parte do Governo.

O Programa Universidade para Todos surge em um contexto marcado pela forte expansão das IES privadas, beneficiadas pela legislação sobre educação superior brasileira, que facilitou a abertura e a manutenção de entidades de caráter privado - especialmente as de fins lucrativos (ALMEIDA, 2012). Segundo dados dos Censos da Educação Superior do INEP, após a LDB de 1996, até 2004, quando o ProUni começou a surgir, as matrículas no setor público cresceram de 832 mil para 1,2 milhão (variação de 44\%), enquanto que no setor privado, aumentaram de 1,5 milhão para mais de 3 milhões (variação de 95\%). Este quadro levou as instituições privadas a uma situação de ociosidade de vagas ${ }^{46}$ (CARVALHO, 2006; SOUSA, 2010), o que as motivou a fazer pressões ao Governo em busca de incentivos para o preenchimento das mesmas. A ociosidade foi gerada não só pela expansão do segmento privado, mas também pelo fato de que poucas pessoas possuíam condições de custear as mensalidades, o que provocava situações de grande inadimplência e evasão (CARVALHO, 2011b).

Por outro lado, a democratização do acesso à educação superior era uma questão latente, pois apenas $10,7 \%$ das pessoas de 18 a 24 anos frequentavam o ensino superior na época (2004). Era também uma grande necessidade atender a uma das metas do Plano Nacional de Educação (PNE) 2001-2010, que pretendia alcançar a taxa bruta de 50\% de matrículas no

\footnotetext{
${ }^{46}$ A questão da ociosidade de vagas no setor privado deve ser problematizada, já que vaga "ociosa" é um termo que possui diferentes acepções, a depender dos atores envolvidos (para gestores institucionais, mantenedoras, para o INEP, etc.). Nesse sentido, neste trabalho é colocado o entendimento de Sousa (2010, p. 7), em que o número de vagas ociosas "traduz a diferença entre a quantidade de vagas com autorização do Ministério da Educação a serem ofertadas em cada IES e o número efetivo de ingressantes nessas mesmas instituições, em cada ano". No entanto, Sousa (2010) ressalta que as vagas ociosas também podem ser observadas como "estoque de vagas", por exemplo, no contexto da política de gestão institucional no setor privado.

${ }^{47}$ Conforme observado nos dados sobre a expansão da educação superior, no Capítulo 1.
} 
ensino superior, e taxa líquida de 33\%. O ProUni surge, então, neste contexto, entre a questão da ociosidade de vagas privadas, e ao mesmo tempo, trazendo a justificativa da necessidade de ampliar o acesso das camadas menos favorecidas ao ensino de nível superior, por meio de um discurso de maior justiça social. Conforme resume Carvalho (2006), a proposta surge

[...] acompanhada pela retórica de justiça social e de inclusão das camadas sociais menos favorecidas, cujo principal indicador é o baixo contingente de alunos de 18 a 24 anos que frequenta o ensino superior. $\mathrm{O}$ evidente respaldo da sociedade civil em busca do diploma de graduação é acompanhado pela pressão das associações representativas do segmento privado (CARVALHO, 2006, p. 980)

O empresariado do setor privado de educação superior, em especial representados pela Associação Brasileira de Mantenedoras de Ensino Superior (ABMES), mas também pela Associação Nacional das Universidades Particulares (ANUP) e o Sindicato das Entidades Mantenedoras de Estabelecimentos de Ensino Superior do Estado de São Paulo (Semesp), que passavam pela crise de ociosidade de vagas, logo interferiram quando então surgiu a redação do projeto de lei para o Programa Universidade para Todos, $n^{\circ}$ 3.582/2004 (CARVALHO, 2011b; ALMEIDA, 2012). O PL previa, por exemplo, apenas a concessão de bolsas integrais (100\%) aos estudantes. O Projeto final, no entanto, devido às pressões do setor privado, agregou também bolsas parciais: de $50 \%$ e de $25 \%{ }^{48}$ (CARVALHO, 2006).

Catani, Hey e Gilioli (2006, p. 130) analisaram que o PL do ProUni "recebeu 292 propostas de emenda, a maioria beneficiando as mantenedoras", ou seja, as instituições privadas de educação superior. Com isso, ocorreram outras flexibilizações importantes em relação ao PL original: aumento dos critérios de renda familiar per capita mínima para a participação dos candidatos; foram retirados trechos com relação à multa (incidente sobre o faturamento) no caso de descumprimento das regras por parte das IES; além de gerar privilégios para a transição de IES sem fins lucrativos, como as filantrópicas, para IES com fins lucrativos, pois a imunidade tributária concedida pelo ProUni constituía-se em um quadro muito mais vantajoso $^{49}$.

\footnotetext{
${ }^{48}$ Apesar disso, como se constata nas estatísticas oficiais sobre o Programa, as bolsas parciais estão em menor número do que as integrais, que representam $70 \%$ do total oferecido desde o início da política.

${ }^{49}$ De acordo com a Lei do ProUni: "As pessoas jurídicas de direito privado, mantenedoras de instituições de ensino superior, sem fins lucrativos, que adotarem as regras de seleção de estudantes bolsistas [...] e que estejam no gozo da isenção da contribuição para a seguridade social [...], que optarem, a partir da data de publicação desta Lei, por transformar sua natureza jurídica em sociedade de fins econômicos, [...] passarão a pagar a quota patronal para a previdência social de forma gradual, durante o prazo de 5 (cinco) anos, na razão de $20 \%$ (vinte por cento) do valor devido a cada ano, cumulativamente, até atingir o valor integral das contribuições devidas" (BRASIL, 2005a, Art. 13).
} 
Portanto, durante o processo de regulamentação do Programa, entre o PL $\left(\mathrm{n}^{\circ}\right.$ 3.582/2004), a Medida Provisória ( $n^{\circ}$ 213/2004) e a redação definitiva da Lei ( $\left.n^{\circ} 11.096 / 2005\right)$, foi possível perceber que, para as IES lucrativas e sem fins lucrativos não beneficentes, as regras de adesão ao ProUni foram se tornando cada vez mais flexíveis, atendendo aos seus propósitos. Por outro lado, para as IES beneficentes de assistência social, as regras foram bem mais rigorosas, já que a adesão ao Programa se tornou obrigatória (CARVALHO, 2011b).

O Relatório do Tribunal de Contas da União (TCU), de 2009, que procedeu uma auditoria operacional no ProUni e também no Fundo de Financiamento Estudantil (Fies), no período de junho a novembro de 2008 , atesta a dupla situação ocorrida naquele momento de criação do ProUni:

[...] a implantação do ProUni não foi calcada em um plano articulado para a educação superior, mas na oportunidade relacionada ao contexto de alta ociosidade das vagas nas IES privadas e a impossibilidade de ampliação das vagas nas IES públicas que contemplasse a demanda por esse nível de ensino (BRASIL, 2009a, p. 42)

Especialmente no momento próximo à sua criação, ocorreram debates que situaram o ProUni como um instrumento que visa muito mais resolver ou minimizar os problemas das Instituições de Ensino Superior do setor privado, do que propriamente a questão da inclusão social. Tal questão se faz presente nas formulações de Carvalho (2006, p. 986), que toma o ProUni como um "instrumento de amenização e fuga do problema das vagas ociosas nas instituições particulares" e Leher (2004, p. 876), que avalia a política como "uma ferramenta que reforça e fortalece ainda mais o setor privado de ensino superior [...] em detrimento do setor público, através da renúncia físcal das instituições que aderem ao Programa”. Para Catani, Hey e Gilioli (2006, p. 128), o "ProUni representa a retomada de uma tradição de políticas de renúncia que mais beneficiam o setor privado do que induzem políticas públicas democratizantes".

A participação do setor privado no sistema de ensino superior brasileiro sempre foi bastante expressiva, restando pouco espaço ao setor público. Conforme observado no Capítulo 1, de acordo com resultados dos Censos da Educação Superior do INEP, há uma média de 90\% de instituições privadas e apenas 10\% de instituições públicas na última década (2003-2013). As IES privadas responderam, em 2013, por 74\% do total de matrículas. O ProUni, embora objetive a democratização do acesso ao nível superior, pode auxiliar a reforçar este processo, ao conceder isenções fiscais para um setor já consolidado como o privado. 
O ProUni surge, então, para os pesquisadores do tema, como uma política que ajudou a intensificar a privatização do ensino superior com recursos públicos, trazendo, de um lado, uma solução para o problema das vagas ociosas nas instituições de ensino particulares; e de outro, promoveu vias de estabilização e expansão das mesmas, a partir dos incentivos concedidos na forma de isenções fiscais. Para Carvalho (2006), há aspectos que refletem a forte relação desses benefícios para com as Instituições de Ensino Superior privadas, sendo uma excelente forma de contenção das crises:

A legitimidade social do programa encontra ressonância na pressão das associações representativas dos interesses do segmento particular, justificada pelo alto grau de vagas ociosas. O PROUNI surge como excelente oportunidade de fuga para frente para as instituições ameaçadas pelo peso das vagas excessivas (CARVALHO, 2006, p. 986, grifo da autora).

Por outro lado, com relação à problemática de intensificação e favorecimento do setor privado por intermédio do ProUni, é importante suscitar alguns questionamentos em relação à abrangência do Programa. Vale ressaltar, e ponderar, que a participação das bolsas ofertadas pelo ProUni no universo de matrículas do setor privado ainda é pouco representativa. Atualizando alguns dos cálculos propostos inicialmente por Carvalho (2011a), verifica-se na Tabela 5 que a proporção do oferecimento de bolsas pelo Programa em relação à totalidade das matrículas no setor privado ainda é pequena, chegando ao máximo de sua participação em 5,6\% em 2009 e 5,5\% em 2012, tendo recuado para 4,7\% em 2013 e 5,2\% em $2014^{50}$. Ou seja, a questão da educação superior privada no Brasil é maior, mais complexa e anterior ao ProUni, o que envolve uma discussão mais abrangente sobre os processos históricos, a atuação dos diversos protagonistas e setores da sociedade e as demandas nesse sentido. O ProUni, sem dúvidas, é um fator influente neste movimento, mas de acordo com sua participação no universo do setor privado, não pode ser tomado como o único ou principal responsável da intensificação deste processo na atualidade.

\footnotetext{
${ }^{50}$ Mesmo se os cálculos forem realizados considerando a relação entre o número de bolsas ativas do ProUni - que somavam aproximadamente 600 mil em 2014, de acordo com RISTOFF (2014) - e as matrículas na rede privada (5.867.011 em 2014), verifica-se que há uma proporção um pouco maior, mas ainda pouco representativa: de $10,2 \%$
} 
Tabela 5 - Número de matrículas em Instituições de Ensino Superior Privadas (Graduação) e número de bolsas ProUni ofertadas

Brasil, 2005 a 2014

\begin{tabular}{cccc}
\hline Ano & $\begin{array}{c}\text { Matrículas em IES } \\
\text { Privadas }\end{array}$ & $\begin{array}{c}\text { Bolsas ProUni } \\
\text { ofertadas }\end{array}$ & $\begin{array}{c}\text { Relação Bolsas ProUni } \\
\text { / Matrículas IES } \\
\text { Privadas }\end{array}$ \\
\hline $\mathbf{2 0 0 5}$ & 3.321 .094 & 112.275 & $\mathbf{3 , 4 \%}$ \\
$\mathbf{2 0 0 6}$ & 3.632 .487 & 138.668 & $\mathbf{3 , 8 \%}$ \\
$\mathbf{2 0 0 7}$ & 3.914 .970 & 163.854 & $\mathbf{4 , 2 \%}$ \\
$\mathbf{2 0 0 8}$ & 4.255 .064 & 225.005 & $\mathbf{5 , 3 \%}$ \\
$\mathbf{2 0 0 9}$ & 4.430 .157 & 247.643 & $\mathbf{5 , 6 \%}$ \\
$\mathbf{2 0 1 0}$ & 4.736 .001 & 241.273 & $\mathbf{5 , 1 \%}$ \\
$\mathbf{2 0 1 1}$ & 4.966 .374 & 254.598 & $\mathbf{5 , 1 \%}$ \\
$\mathbf{2 0 1 2}$ & 5.140 .312 & 284.622 & $\mathbf{5 , 5 \%}$ \\
$\mathbf{2 0 1 3}$ & 5.373 .450 & 252.374 & $\mathbf{4 , 7 \%}$ \\
$\mathbf{2 0 1 4}$ & 5.867 .011 & 306.726 & $\mathbf{5 , 2 \%}$ \\
\hline Fonte: INEP - Censos da Educação Superior; SisProUni (BRASIL, 2005b, 2012b, 2015b, 2015h). \\
Elaboração própria.
\end{tabular}

A articulação que o ProUni realiza com a política fiscal e o financiamento dessas bolsas de estudo, por meio da renúncia tributária, é um ponto extremamente importante a ser discutido, pois reflete a complexa relação de uma política voltada ao ensino superior privado, em contraponto às demandas do meio universitário em busca da democratização do acesso a esse nível educacional. Segundo Carvalho (2011a),

\begin{abstract}
A renúncia fiscal abrange a história recente da educação superior brasileira. Este mecanismo tornou-se elemento central no financiamento do segmento particular, à medida que promoveu o crescimento intensivo dos estabelecimentos na prosperidade econômica e, principalmente, garantiu a continuidade da atividade educacional em períodos de crise econômica ou de queda de demanda, por meio da redução de seu impacto sobre custos e despesas inerentes à prestação de serviços. (CARVALHO, 2011a, p. 3)
\end{abstract}

As Instituições de Ensino Superior com fins lucrativos são, efetivamente, as mais beneficiadas ao aderirem ao ProUni, conforme mostra a Tabela 6, das alíquotas e bases de cálculo para as IES. Tais instituições ficam isentas do recolhimento de quatro tributos, passando a recolher apenas o INSS patronal. As entidades sem fins lucrativos (confessionais e comunitárias) deixam de recolher o PIS e a COFINS, pois já são isentas do IRPJ e da CSLL (Carvalho, 2011b). As entidades beneficentes ou filantrópicas são as menos beneficiadas pelo 
ProUni: deixam de recolher apenas o PIS sobre a folha de pagamento, "mas passaram a ser obrigadas a participar do programa para manter o título de beneficência” (BRASIL, 2009a, p. 69).

Tabela 6 - Alíquotas e base de cálculo dos Tributos Federais por categoria de IES Comparação com e sem ProUni

Brasil, 2011

\begin{tabular}{|c|c|c|c|c|c|c|}
\hline \multirow[t]{2}{*}{ Tributos } & \multicolumn{2}{|c|}{ Com fins lucrativos } & \multicolumn{2}{|c|}{$\begin{array}{c}\text { Sem fins lucrativos } \\
\text { (Confessional / } \\
\text { Comunitária) }\end{array}$} & \multicolumn{2}{|c|}{$\begin{array}{l}\text { Sem fins lucrativos } \\
\text { (Filantrópica) }\end{array}$} \\
\hline & Atual & PROUNI & Atual & PROUNI & Atual & PROUNI \\
\hline IRPJ & $\begin{array}{l}25 \% \mathrm{x} \\
\text { lucro }\end{array}$ & - & - & - & - & - \\
\hline CSLL & $\begin{array}{l}9 \% \mathrm{x} \\
\text { lucro }\end{array}$ & - & - & - & - & - \\
\hline COFINS & $\begin{array}{l}3 \% \times \\
\text { receita }\end{array}$ & - & $\begin{array}{l}3 \% \times \\
\text { receita }\end{array}$ & - & - & - \\
\hline PIS & $\begin{array}{c}0,65 \% \mathrm{x} \\
\text { receita }\end{array}$ & - & $1 \% \mathrm{x}$ folha & - & $\begin{array}{l}1 \% x \\
\text { folha }\end{array}$ & - \\
\hline $\begin{array}{c}\text { INSS } \\
\text { (patronal) }\end{array}$ & $\begin{array}{l}20 \% \mathrm{x} \\
\text { folha }\end{array}$ & $\begin{array}{l}20 \% \mathrm{x} \\
\text { folha }\end{array}$ & $\begin{array}{c}20 \% \mathrm{x} \\
\text { folha }\end{array}$ & $\begin{array}{l}20 \% \mathrm{x} \\
\text { folha }\end{array}$ & - & - \\
\hline
\end{tabular}

Fonte: Carvalho (2011b)

Como mostra a Tabela 6, é possível perceber que as Instituições de Ensino Superior, especialmente as com fins lucrativos, são bastante beneficiadas com a política de renúncia fiscal, pois quando aderem ao programa, podem ser isentar de praticamente todos os tributos fiscais que recolhiam. Neste período, grande parte do crescimento e fortalecimento das IES privadas, que participam do ProUni, se deu por conta deste incentivo (Carvalho, 2011b). Segundo estatísticas oficiais sobre o ProUni no período de 2005 a 2014, 57\% do total das bolsas concedidas foram de Instituições de Ensino com fins lucrativos (BRASIL, 2015h).

O relatório de auditoria do TCU salientou que, na época (2009), a isenção fiscal concedida às instituições era total, não possuindo relação com o número de bolsas efetivamente ocupadas; "ou seja, se uma entidade oferta 10 bolsas para um curso específico, mas apenas 2 bolsas são efetivamente ocupadas, a isenção fiscal recebida é a mesma se todas houvessem sido ocupadas" (BRASIL, 2009a, p. 69). Após críticas da auditoria, a legislação do ProUni foi alterada, conforme observado anteriormente, em 2011 - em que a isenção fiscal passou a ter seu cálculo vinculado à proporção de ocupação efetiva das bolsas devidas. 
Segundo os Demonstrativos dos Gastos Governamentais Indiretos de Natureza Tributária (Gastos Tributários), divulgados pela Secretaria da Receita Federal anualmente, há um gasto estimado somente com o ProUni de R \$ 5,5 bilhões de reais no período de 2005 a 2015 (Gráfico 5). Para 2016, a projeção dos gastos com base no Projeto de Lei Orçamentária Anual (PLOA) alcança cerca de R \$ 1,3 bilhão. Entretanto, esse valor representa, no ano, apenas 0,47\% dos gastos tributários totais.

Gráfico 5 - Estimativa de renúncia fiscal das entidades privadas que aderiram ao ProUni. Brasil, 2005 a 2016.

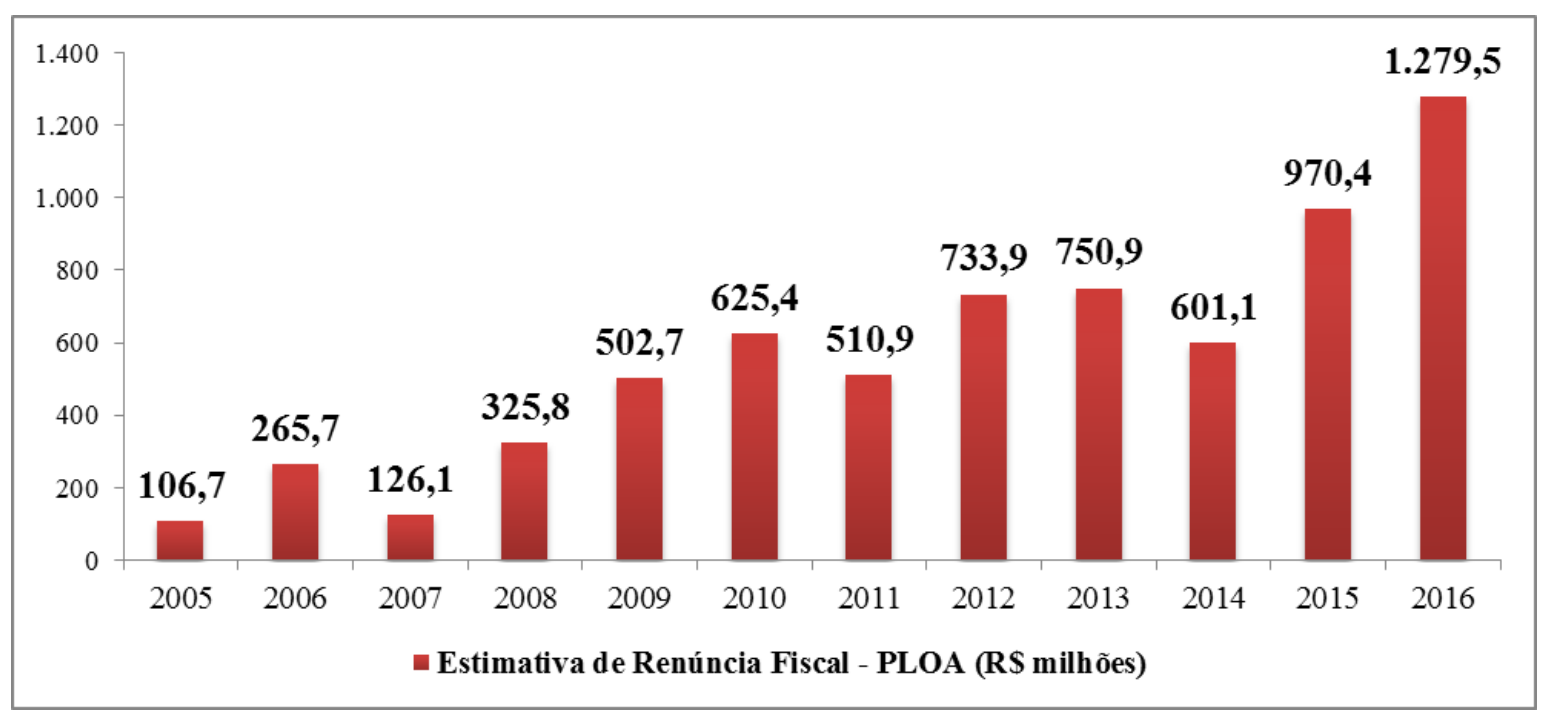

Fonte: Receita Federal do Brasil. Demonstrativos dos Gastos Tributários (BRASIL, 2016g) Elaboração própria.

Para Leher (2004, p. 869), neste processo “a comodificação da educação vem sendo operada também por intermédio do Estado". O autor acredita que o ProUni é mais um reflexo do estabelecimento de novas modalidades de privatização no campo da educação, por meio de Parcerias Público-Privadas (PPPs): "Essas parcerias redefinem o dever do Estado na realização do direito à educação, ampliando a esfera privada em detrimento da esfera pública” (LEHER, 2004, p. 876).

Com relação à questão da democratização do acesso à educação superior, no qual o ProUni visa exercer seu papel, são envolvidas outras questões, como por exemplo, a da permanência dos beneficiários. Sabe-se que para a grande maioria dos ingressantes no ensino superior, a meta não é apenas ingressar na universidade, faculdade ou centro universitário; é conseguir permanecer e concluir o curso integralmente. Nesse ponto, o ProUni pode ser apenas uma parte do processo de democratização, pois é enfatizado o acesso, em detrimento da permanência dos estudantes beneficiados. O ProUni disponibiliza, desde o início, alguns 
incentivos como a Bolsa Permanência e estágios com a Caixa Econômica Federal. Entretanto, no caso da Bolsa Permanência, este auxílio fica restrito a estudantes de cursos integrais - uma realidade de apenas 4\% dos beneficiários (BRASIL, 2015h). Em termos de sustentação financeira dos bolsistas, é possível utilizar o Fies no caso de necessidade de financiamento do valor restante das mensalidades de bolsas parciais.

Outro ponto crítico com relação à permanência é que as Instituições de Ensino possuem autonomia para solicitar ou não a comprovação de renda dos bolsistas regularmente. Conforme mencionado anteriormente na seção sobre o funcionamento do Programa, algumas instituições adotam o sistema de comprovação de documentos periodicamente (anual ou semestral), o que pode impedir, por exemplo, o aluno de entrar no mercado de trabalho (ou alguém de seu grupo familiar), ou mudar de emprego, se o salário recebido for superior ao da renda declarada no momento que conseguiu a bolsa. Esse estudante, portanto, será impedido de continuar na condição de bolsista ProUni. Esse processo, de certa forma, coloca empecilhos para que o aluno possa ascender socialmente, e consequentemente, conquistar mais condições de permanecer no curso. Por outro lado, conforme atestam os trabalhos de Costa (2008) e Almeida (2012), algumas instituições de ensino não adotam este sistema de comprovação regular, e somente solicitam a documentação uma única vez, no ato da entrada.

Todavia, por ser uma política recente, e configurar um processo político em movimento, o ProUni ainda é amplamente investigado, cujos impactos ainda estão sendo mensurados. No que tange à oferta de bolsas de estudo por parte dos cursos que participam do Programa, apesar de existir um relativo controle em relação à avaliação de infraestrutura, corpo docente, formato do curso, etc. (por meio de critérios de desempenho do Sistema Nacional de Avaliação da Educação Superior, o SINAES), ainda há muitos entraves para se mensurar a qualidade e o retorno social desses cursos, considerando que são ofertados na esfera privada.

À época de sua criação, surgiram dúvidas quanto a qualidade dos cursos que ofereciam bolsas (CATANI, HEY e GILIOLI, 2006; PAULA, 2006), assim como se verificou, posteriormente, uma "heterogeneidade educacional das instituições às quais os bolsistas são encaminhados" (ALMEIDA, 2012, p. 252). Destaca-se aqui que não há menção nestes trabalhos sobre estatísticas gerais a esse respeito, pois não haviam sido disponibilizadas até o momento das pesquisas. O rol de cursos e instituições participantes do ProUni ainda é pouco conhecido, sendo divulgado apenas na abertura de processos seletivos ou de solicitações especiais junto ao MEC. No que tange à qualidade desses cursos superiores, um levantamento realizado em 2007 pelo jornal O Estado de S. Paulo apontou que 462 dos 923 cursos com as notas mais baixas no 
Exame Nacional de Desempenho dos Estudantes (ENADE) estavam oferecendo bolsas via ProUni no próximo semestre letivo ao da reportagem (PARAGUASSÚ, 2007). Por essas e outras razões, considerou-se importante, nesta pesquisa, investigar de forma mais aprofundada os cursos que ofertaram bolsas pelo ProUni, o que será realizado no próximo Capítulo.

De outro lado, observando a política pela ótica da inclusão social, o que se verifica é que a discussão do ProUni tem sido polarizada. Carvalho (2011a, p. 17) aborda outros efeitos da política, estabelecendo um certo contraponto às críticas ao analisar dados do IBGE, em que se constata que a partir de 2005, ano da implementação do ProUni, até 2008, as taxas de escolaridade líquida e bruta das camadas mais pobres da sociedade aumentaram consideravelmente (embora ainda persista muita desigualdade), e reconhece que o ProUni contribuiu na facilitação do acesso ao ensino de nível superior aos estratos menos favorecidos da sociedade:

[...] é possível deduzir que o PROUNI foi um programa bem sucedido de financiamento da demanda à medida que contribuiu para ampliar o acesso das camadas mais pobres, como se observa o aumento da escolaridade líquida e bruta mais que proporcional dos três quintis mais baixos de renda (CARVALHO, 2011a, p. 17)

Faz-se necessário, portanto, apresentar alguns aspectos da política por meio da ótica da inclusão e mobilidade social. Nesse contexto, o ProUni têm sido observado enquanto política de ação afirmativa e de caráter provisório, objetivando a compensação ${ }^{51}$ das históricas desigualdades sociais que o país possui - em que pesem suas contradições e seu viés de privatização -, muito embora, como já foi observado, a sua participação no setor privado ainda seja reduzida. Políticas como o ProUni, ao favorecer o acesso da população com baixo poder aquisitivo a um espaço tradicionalmente marcado por grande concentração de renda, o universitário (RISTOFF, 2014), podem ajudar a reduzir, ainda que de forma lenta, essa situação de desigualdade (BARREYRO e COSTA, 2015).

Ainda, pesquisas como a de Costa (2012), realizadas com beneficiários do Programa apontam que, em grande parte dos casos, os bolsistas são os primeiros membros da família a cursar um ensino superior, o que gera possibilidades de ascensão social e ampliação de oportunidades aos indivíduos e entre as gerações de suas famílias.

\footnotetext{
${ }^{51}$ Entendendo que essas políticas são "mecanismos de que o Estado dispõe para repor e atenuar as desigualdades que marcam a sociedade brasileira no que se refere a oportunidades de acesso à Educação Superior" (COSTA, 2012, p. 50), em especial com relação à juventude, considerada a faixa etária ideal para ingressar nesse nível educacional.
} 
Na mesma linha de reflexão, ao analisar o percurso das políticas de inclusão social, entre elas o ProUni, Ristoff (2014) sinaliza que:

[...] é inescapável a conclusão de que as políticas de inclusão dos últimos anos estão trazendo ao campus legiões de estudantes que representam a primeira geração da família a ter oportunidade de ser aluno de graduação. Os impactos destas medidas com certeza se farão sentir para muito além da valorização das oportunidades educacionais, devendo refletir diretamente e quase que imediatamente na qualidade de vida das pessoas e ao longo dos anos no desenvolvimento do país (RISTOFF, 2014, p. 741-742).

De fato, não é possível desprezar os ganhos da obtenção de um diploma de nível superior na realidade brasileira, principalmente quando relacionados ao aumento da remuneração e a melhor condição de inserção no mercado de trabalho, esfera em que a maior parte do contingente economicamente ativo ainda se localiza em empregos de baixa qualificação e remuneração. Além disso, "as barreiras sociais superadas pelos egressos do ProUni não podem ser observadas somente numa lógica de conquistas individuais, e sim numa perspectiva coletiva inserida em um contexto favorável de desenvolvimento econômico e social" (COSTA, 2013, p. 78).

Em termos de avaliação de uma política pública, não basta apenas considerar os aspectos de formulação e interesses envolvidos, mas também "quanto aos resultados das políticas, importa ter em conta os segmentos efetivamente beneficiados por elas" (BARRETTO, 2009, p. 504).

Não se pode negar que o ProUni possui um forte significado social para a maioria de seus beneficiários e possibilita, ainda que com ressalvas, avanços em termos de mobilidade e ascensão social. O diploma de ensino superior no Brasil, dado o baixo nível de matriculados nesse segmento, ainda possui grande relevância social, cujos impactos e possíveis ganhos, além de econômicos, também se expandem na dimensão simbólica ${ }^{52}$, possibilitando novas trajetórias de vida, em aspectos culturais, do conhecimento, alargamento das redes sociais e ampliação de horizontes e perspectivas. Nesse contexto é importante ressaltar, de acordo com Mello Neto,

\footnotetext{
52 A questão do simbolismo do diploma de nível superior, bem como seu papel na sociedade é discutida por Bourdieu e Boltanski (2007), que relacionam a obtenção do diploma a privilégios sociais. Para os autores, os sistemas de ensino não são neutros, pois geram efeitos no aumento ou redução das desigualdades sociais. $\mathrm{O}$ diploma, nesse contexto, seria um tipo de certificação que pode transferir ao seu portador novos poderes e oportunidades, além de ser uma moeda de troca no mercado de trabalho, condições que os autores denominam de ampliação do capital cultural e do capital econômico. No entanto, a implicação do valor dos diplomas adquiridos pelos bolsistas do ProUni, em que pese a heterogeneidade de estudantes, cursos e instituições, não será objeto de discussão neste trabalho.
} 
Medeiros e Catani (2014), que o ProUni representa (no caso dos bolsistas pesquisados pelos autores) uma nova construção de identidade social, já que, em diversos casos, "os estudantes são expostos a um ambiente em que se configuram relações sociais extremamente distintas das suas" (MELLO NETO, MEDEIROS e CATANI, 2014 p. 586), situação em que os demais estudantes (não bolsistas) das instituições particulares geralmente possuem trajetórias distintas, seja por questões oriundas da renda, ou de fatores como a raça/cor e a trajetória escolar.

Em pesquisas realizadas com egressos do Programa, dentre as quais se destacam as de Amaral e Oliveira (2011) e Costa (2012), a partir de abordagens qualitativas relacionando o ProUni a temas como ascensão social, aumento de renda, facilitação no ingresso ao mercado de trabalho, motivação, autoestima, alargamento da rede social e ampliação do universo cultural dos beneficiários, foi observado que "o ProUni tem demonstrado eficácia pela baixa taxa de evasão e que os egressos experimentaram novas trajetórias profissionais e pessoais" (AMARAL e OLIVEIRA, 2011, p. 861), no caso da pesquisa realizada em entrevista com seis egressos e análise do perfil de bolsistas em duas IES do Rio de Janeiro. Já na pesquisa de Costa (2012), realizada com 146 egressos via questionário eletrônico e 6 egressos na forma de entrevista presencial, foi constatado que os bolsistas relataram interesse em continuar os estudos após a graduação; que a renda mensal individual desses egressos aumentou consideravelmente após a conclusão da graduação; e que o ProUni possibilitou maiores chances de garantir empregos menos precários e com maior estabilidade.

A aceitação social do ProUni também é grande, conforme mostram algumas pesquisas de opinião. Uma pesquisa encomendada pelo MEC ao Instituto Brasileiro de Opinião Pública e Estatística (IBOPE), realizada em março de 2009 com 1.200 bolsistas integrais participantes do ProUni, apontou que $80 \%$ dos entrevistados formados pelo ProUni estavam trabalhando; para $68 \%$, sua vida melhorou muito após o ProUni, e $26 \%$ afirmam que sua vida melhorou pelo menos um pouco. Oito em cada 10 entrevistados disseram haver motivação entre seus familiares para iniciar ou continuar seus estudos, depois da experiência do ProUni. Também segundo a mesma pesquisa, em relação a renda, $68 \%$ dos entrevistados afirmam que a sua renda familiar melhorou de uma maneira geral, sendo que destes, $28 \%$ afirmam que melhorou muito e $40 \%$ que melhorou um pouco; $97 \%$ dos entrevistados afirmaram que querem continuar os estudos (cursos de especialização, mestrado e doutorado).

Segundo pesquisa do Instituto de Pesquisa Econômica Aplicada (IPEA) de 2011 para elaboração do Sistema de Indicadores de Percepção Social (SIPS), em que foram entrevistadas 2.770 pessoas nas cinco regiões do país, o ProUni possui uma alta visibilidade social $-61 \%$ 
dos entrevistados afirmaram conhecer o Programa; 64\% achavam que o número de vagas ofertadas era pouco; e 73,4\% opinaram que o ProUni deve ser ampliado. Entretanto, sobre a isenção de impostos que o ProUni institui, 37,7\% opinaram que deve ser mantida e 27,3\% que deve ser ampliada; já 18,6\% opinaram que deve ser reduzida, e 16,3\%, extinta.

Com relação ao desempenho acadêmico dos bolsistas ProUni em relação ao dos estudantes não-ProUni, os resultados também têm sido positivos. Uma avaliação do desempenho de bolsistas ProUni no ENADE 2007 foi publicada pelo boletim Na Medida, de Estudos Educacionais do INEP, em 2009. Os resultados apontaram que, entre os alunos ingressantes, em todas as áreas analisadas pela pesquisa, os alunos com bolsa ProUni possuíam média maior no ENADE do que aqueles sem bolsa ProUni. Já entre os alunos concluintes, na maioria das áreas avaliadas, não houve diferença estatisticamente significativa entre os alunos ProUni e os alunos não-ProUni. O boletim indica ainda que

[...] de uma maneira geral, os resultados indicam ser muito pouco provável que a inclusão dos alunos bolsistas tenha piorado a qualidade dos cursos de um modo geral, já que o desempenho deles parece ser igual ou superior ao de seus colegas de curso. (BRASIL, 2009b, p. 18).

O jornal O Estado de S. Paulo apresentou um estudo, em 2014, realizado por meio do cruzamento entre os beneficiários de bolsas integrais do ProUni e seu desempenho no ENADE em 2010, 2011 e 2012 - e constatou que as maiores notas médias foram conseguidas pelos bolsistas (TOLEDO e SALDAÑA, 2014). Os bolsistas, inclusive, possuíam desempenho superior à média geral, ao de estudantes de escolas públicas e ao de alunos mais ricos (o estudo envolveu, entre outras informações, o perfil socioeconômico dos estudantes).

Nesse sentido, o ProUni contempla o caráter de política de ação afirmativa, pois ao incluir recortes do público alvo por renda, raça/cor e etnia, faz parte de uma tentativa de compensação histórica das desvantagens educacionais que o país possui - entre elas, que o nível de acesso à educação superior ainda é muito baixo. Apesar da grande inclusão de estudantes no sistema de ensino superior, atendendo, segundo o MEC, a mais de 1,4 milhão de bolsistas em dez anos de política, além de possuir medidas que corroboram os interesses da sociedade e dos movimentos sociais, verifica-se que o papel do ProUni na democratização do acesso é um processo muito mais complexo. É possível perceber que a democratização encontra reais empecilhos na escassez de vagas públicas e gratuitas - situação em que o ProUni não está envolvido diretamente. 
Com relação ao argumento de que os recursos despendidos ao ProUni poderiam ser utilizados na criação de vagas em instituições públicas, tal verdade poderia ser concretizada. Entretanto, historicamente, a política de Estado com relação à expansão educacional tem sido orientada estrategicamente ao setor privado (salvo exceções que devem ser ressaltadas, como a expansão da Rede Federal de Educação Superior, que conforme observado no Capítulo 1, embora timidamente, contribuiu no mesmo período para a expansão da esfera pública). Esses esforços, entretanto, ainda não foram suficientes para que a lógica do sistema de educação superior no país fosse deslocada de sua base do setor privado, para o setor público.

O ProUni, conforme observado, foi formulado entre outros motivos objetivando alcançar a meta do Plano Nacional de Educação (PNE) 2001-2010, que pretendia aumentar a proporção de jovens de 18 a 24 anos matriculados no ensino superior para 33\%. Segundo dados da PNAD-IBGE de 2013, a taxa líquida de matrículas encontra-se, ainda, em 16,5\%. Com relação a essa necessidade, há um debate em torno da importância do setor privado educacional, o que de acordo com Ribeiro (2013), leva a uma situação em que a educação superior oferecida pelas instituições privadas ainda não pode ser descartada, considerando que a inversão da lógica privada para a lógica pública é uma tarefa a ser realizada, mas que, talvez, só poderá ser efetivada a longo prazo. Conforme afirma Oliveira (2009),

\begin{abstract}
Observa-se o aumento da demanda, resultante da regularização do fluxo no ensino fundamental, e do subsequente crescimento do ensino médio. Ao mesmo tempo, mantém-se a crônica dificuldade de se implementar uma política pública consistente, que permita expandir a oferta de modo a competir quantitativamente com a iniciativa privada. (OLIVEIRA, 2009, p. 741-742)
\end{abstract}

Além disso, outro fator importante para reflexão está relacionado com a expansão das vagas públicas versus as condições de acesso, já que mesmo no ensino superior público, sem políticas de compensação, o acesso continua impossibilitado - ou seja, a simples abertura de vagas públicas não rompe com o caráter elitista e excludente da sociedade e do setor educacional. Este fato conduz a uma reflexão maior, sobre as deficiências em todos os níveis educacionais que o país possui. No ensino médio, por exemplo, ainda há desigualdades de acesso e a qualidade educacional é sofrível na maioria dos casos (FRIGOTTO, 2013). Há um descompasso na passagem do ensino médio para o ensino superior, em que os alunos de camadas mais pobres da sociedade encontram dificuldades no ingresso (provas e vestibulares de alta complexidade) e na permanência (acompanhar os conteúdos, a carga horária dos cursos, etc.). 
Portanto, em um processo anterior ao acesso à educação superior, verifica-se que é necessário fortalecer a educação básica, na tentativa de equalizar a competição educacional existente. Ainda predomina, na sociedade brasileira, a ideia de "os jovens das camadas mais pobres verem a universidade pública como uma difícil e remota possibilidade" (RIBEIRO, 2013, p. 30), ou seja, o ensino superior no setor público é "ainda timidamente permeável a esse tipo de aluno, pois não está voltado às legítimas demandas desses trabalhadores-estudantes" (ALMEIDA, 2012, p. 254). Para Barretto (2009, p. 497), "as novas formas de marginalização e de exclusão produzem diferentes recortes nas relações sociais, sendo que os segmentos mais vulneráveis tendem a ser aqueles mais precariamente atendidos pelos serviços públicos".

Segundo Leher (2013, p. 31), é preciso “mudar a direção da política educacional”, cujo eixo deve ser "público e universal"; entretanto, essas ações requerem um longo prazo para sua efetivação, e dependem de muitos fatores institucionais, jogos de poder, interesses políticos e econômicos, entre outros. Esses esforços devem ser intensificados e desmistificados; porém, é verificado um processo em que, em termos burocráticos, leva muito mais tempo, especialmente considerando o cenário educacional do país, no qual a educação superior não é incorporada como um bem público, cujo Estado historicamente pouco se esforçou em modificar a lógica de priorização do setor privado.

O ProUni, neste processo, foi se constituindo como uma alternativa para a facilitação do acesso ao segmento privado. Contudo, não se deixa de refletir criticamente sobre como essa democratização do acesso vem sendo realizada. Ainda faltam muitos aspectos da política a serem investigados e complementados, principalmente com relação à permanência dos bolsistas nas instituições, e à qualidade e retorno social das instituições e dos cursos participantes. Além disso, o relatório do Tribunal de Contas da União (TCU) conclui em sua auditoria sobre o ProUni (e também sobre o Fies) que

[...] o ProUni e o Fies são programas bastante importantes para garantir o ingresso e a manutenção de alunos no ensino superior, e a melhoria do nível de escolaridade da população, sendo um grande passo rumo ao atendimento das metas previstas no PNE e no PDE, entretanto, verificou-se que os programas ainda necessitam de diversos aprimoramentos que auxiliarão tanto gestores, como IES e beneficiários a alcançarem seus objetivos de forma mais eficiente, eficaz, efetiva e econômica aos cofres públicos (BRASIL, 2009a, p. 108). 
Também é importante que sejam pensadas, além de políticas complementares ao Programa, políticas concomitantes que visem garantir a expansão do setor público educacional, conforme coloca Marinelli (2009):

[...] o ProUni deve ser analisado como parte de uma política educacional para o ensino superior no Brasil, tendo outras ações tão ou mais importantes, voltadas inclusive à expansão e à democratização do acesso ao ensino público e gratuito. O programa não resume e não resolve sozinho problemas que as políticas universalistas não conseguiram resolver, principalmente se entendido como estratégia para a diminuição da atuação do Estado, justificado pela desarticulação do setor público e consequente ampliação da presença desqualificada da iniciativa privada, notadamente aquela que se apoia na mercantilização da educação. Até mesmo porque não basta garantir a oportunidade de acesso, mas sim igualdade de oportunidades para a educação superior de qualidade (MARINELLI, 2009, p. 536-537)

Em suma, o ProUni, de acordo com as discussões e o arcabouço teórico relativo ao tema, parece tender a relacionar-se mais a uma mudança conjuntural, do que estrutural. Certamente, a política não pode ser tomada com a pretensão de ser uma solução definitiva para os problemas da educação superior brasileira, nem necessariamente caminhar para a efetiva universalização desse direito. É uma política permeada por contradições e possui intrínseca ligação com a privatização, no sentido de não se deslocar da lógica privada para atrair ou realizar investimentos no setor público. Por outro lado, é uma alternativa que se utiliza da expressiva expansão do setor privado para introduzir ações afirmativas, devendo-se levar em consideração que é uma ação governamental que visa minimizar desigualdades históricas brasileiras, ao democratizar o acesso a grupos vulneráveis da sociedade - grupos estes que, há dez anos, tinham mínimas chances de ingressar neste nível educacional. De acordo com Costa (2013), o acesso não é, isoladamente, uma solução, mas sem sua facilitação, torna-se ainda mais difícil uma evolução na escala social brasileira.

É certamente um exercício complexo mensurar se a expansão do acesso à educação superior nas últimas décadas deve-se ao ProUni; no entanto, estes indicadores poderiam ser ainda piores sem o surgimento do Programa. De acordo com os Censos Demográficos, realizados pelo IBGE, o número de brasileiros com diplomas universitários passou de 4,4\% em 2000 para 7,9\% em 2010. Também segundo a PNAD-IBGE, cujos dados foram expostos no Capítulo 1, a taxa bruta de escolarização da educação superior chegou a 32,3\% em 2013, seguindo uma tendência positiva desde 2003 (quando registrava 20,2\%). Já a taxa líquida estava em 16,5\% (em 2003, era de 11\%). 
Considera-se que tal política não deve possuir um fim em si mesma, adquirindo portanto um "prazo de validade" intrínseco (COSTA, 2013, p. 79). A política do ProUni não deve caminhar sozinha, sem a ação de conciliar, coerente e concomitantemente, políticas para aprimorar o próprio Programa, que é relativamente recente (no sentido de melhorar a qualidade do acesso, garantir a permanência e acompanhamento dos egressos, entre outros pontos). Também verifica-se a necessidade de políticas mais abrangentes e de caráter universal, que viabilizem a longo prazo o direito à educação em todos os níveis educacionais, a partir do investimento público em instituições de qualidade - ou seja, as capazes de reunir o tripé ensino, pesquisa e extensão, o qual considera-se fundamental para promover o papel da produção de conhecimento e autonomia dos indivíduos, em uma sociedade de tendências hegemônicas (DIAS SOBRINHO, 2002).

Faz-se necessário, portanto, uma perspectiva de mudança e tensionamento nas políticas públicas, que busquem também se contrapor à lógica do capitalismo educacional e da naturalização do empreendedorismo na educação, combinando as ações afirmativas para os estudantes mais vulneráveis à expansão do segmento público de educação superior, que promovam verdadeiros espaços públicos de produção e socialização do conhecimento. A educação, portanto, deve ser um direito fundamental, e não apenas uma mercadoria ao serviço do modelo econômico vigente.

De forma a sintetizar os elementos criticados e defendidos sobre o ProUni expostos anteriormente, é possível realizar um resumo das críticas mais frequentes que o ProUni suscita, principalmente sobre:

- O ProUni ser uma política que segue o receituário neoliberal, ou seja: não modifica, essencialmente, a lógica de mercadorização presente na educação superior brasileira. $\mathrm{O}$ Programa é caracterizado por privilegiar o setor privado em detrimento do setor público, principalmente por conceder benefícios na forma de isenções fiscais, que agravam o problema;

- O ProUni frequentemente é visto como uma política transitória, ou seja, sem capacidade de mudança real das estruturas de desigualdade presentes na sociedade, ou mesmo caminhar em direção à universalização do direito à educação no país;

- A política é criticada por focar apenas no acesso, e não na permanência dos estudantes, o que aparece como um ponto frágil para os beneficiários do Programa; 
- Os cursos cujas bolsas do ProUni são ofertadas podem ter qualidade incerta, bem como as instituições que os oferecem; além disso, foi constatada uma grande heterogeneidade das IES que aderem o Programa.

Por outro lado, são apresentados também pontos defendidos sobre o Programa, embora essa seja uma dimensão menos frequente nas pesquisas sobre o tema. São, em síntese:

- O ProUni é avaliado, em que pese seu viés ligado ao setor privado, como uma política que possui caráter de ação afirmativa, ou seja, busca a promoção da democratização do acesso à educação superior para as parcelas menos favorecidas da sociedade;

- A política é identificada por um caráter transitório, ou seja, é uma medida implementada para atender à demanda reprimida pelo acesso a esse nível educacional, levando-se em conta que acesso e expansão no setor público são questões complexas e de longo prazo;

- O ProUni, considerando a dimensão social e simbólica, gera possibilidades de ascensão, mobilidade, ampliação de horizontes e perspectivas (culturais, de conhecimento, de relações, etc.), para seus beneficiários, inclusive com efeito positivo e multiplicador em suas famílias e comunidades.

Nesse sentido, é importante enxergar o ProUni como um processo dual, em que Carvalho (2011a) sintetiza ao afirmar que o ProUni cumpre o duplo papel a que se presta: estimula a iniciativa privada, por meio das generosas isenções fiscais, que beneficiam especialmente as entidades com fins lucrativos; contudo, ao mesmo tempo, também foi capaz de priorizar o acesso ao ensino de nível superior aos grupos menos favorecidos da sociedade.

Por fim, com relação ao levantamento bibliográfico realizado sobre o Programa Universidade para Todos, foi possível constatar alguns aspectos ainda não investigados. Ainda há poucas estatísticas disponibilizadas oficialmente sobre o ProUni, sendo que grande parte da produção acadêmica a respeito do tema se deu por intermédio de informações colhidas em pesquisas qualitativas, sobretudo na forma de entrevistas com os bolsistas - que, certamente, captam uma dimensão muito rica em detalhes sociais, culturais e econômicos. No entanto, ainda faltam análises de dimensões quantitativas do Programa, pois muitas delas ainda não são completamente conhecidas. Questionamentos como os de Almeida (2010) permeiam as análises sobre o Programa: 
[...] o ProUni possibilita, de fato, acesso dos indivíduos de baixa renda a alguns cursos mais disputados e prestigiados, carreiras às quais, regularmente, não tem acesso nas universidades públicas. Entretanto, como o MEC não disponibiliza informações específicas, prospecções mais sólidas não podem ser feitas pelos pesquisadores do tema. Restam várias perguntas sem respostas: qual a proporção desses estudantes no conjunto dos beneficiados? Em quais universidades estão? Qual a posição de tais universidades no conjunto do sistema de ensino superior? (ALMEIDA, 2010, p. 11)

Além destes, outros inúmeros questionamentos são gerados durante as leituras sobre o ProUni, especialmente sobre detalhamentos específicos sobre: qual o alcance geográfico da política? Quais IES fazem parte da totalidade do Programa, e de que forma estão se beneficiando com essa política? Quais são os cursos que ofertam bolsas? As IES e os cursos que aderem ao Programa são de qualidade (e sobre qual qualidade se está falando)? A avaliação dos cursos e IES participantes do ProUni consegue realizar-se efetivamente e assegurar um padrão mínimo de qualidade aos cursos? Quais critérios são utilizados para este controle?

Realizando uma problematização mais ampla, o ProUni pode trazer baixa qualidade na formação de seus beneficiários? A implementação do ProUni, por meio do caráter de política de ação afirmativa, leva ou não a uma maior ascensão e promoção de justiça social ao conjunto dos beneficiários? São percebidas, ainda, muitas lacunas nesse sentido, e muito a ser descoberto em futuras pesquisas sobre o tema.

Embora não seja possível responder a todas essas questões nesta pesquisa, o objetivo é reunir elementos que possam contribuir para a reflexão de alguns aspectos sobre o ProUni. Na seção a seguir, são apresentadas e analisadas algumas estatísticas sobre a política, em torno dos dez anos de sua implementação.

\subsection{O ProUni: bolsas ofertadas e perfil dos bolsistas $(2005-2014)^{53}$}

Conforme já explicitado no começo deste Capítulo, segundo informações oficiais do Ministério da Educação (MEC), desde seu início (2005) até o segundo semestre de 2014 - ou seja, em dez anos de política, o ProUni inseriu mais de 1,4 milhão de estudantes em cursos de graduação, concedendo $70 \%$ de bolsas integrais.

Conforme mostra o Gráfico 6, o número de bolsas ofertadas, no total, cresce ano após ano desde a implementação do Programa, com exceção dos anos de 2010 e 2013. O ano de 2014

\footnotetext{
${ }^{53}$ Os dados desta seção foram extraídos do website oficial do ProUni (BRASIL, 2015h).
} 
possui a maior oferta de bolsas desde o início da política, com um total de 306.726 bolsas, a maioria integral (205.237, ou 67\%). As bolsas parciais somam 101.489 (33\%). Com exceção do ano de 2008, em todos os outros a oferta de bolsas integrais foi maior do que de parciais. No total do período, foram oferecidas 2.227.038 bolsas de estudo pelo Programa.

Gráfico 6 - Número de bolsas do ProUni ofertadas por ano.

Brasil, 2005-2014

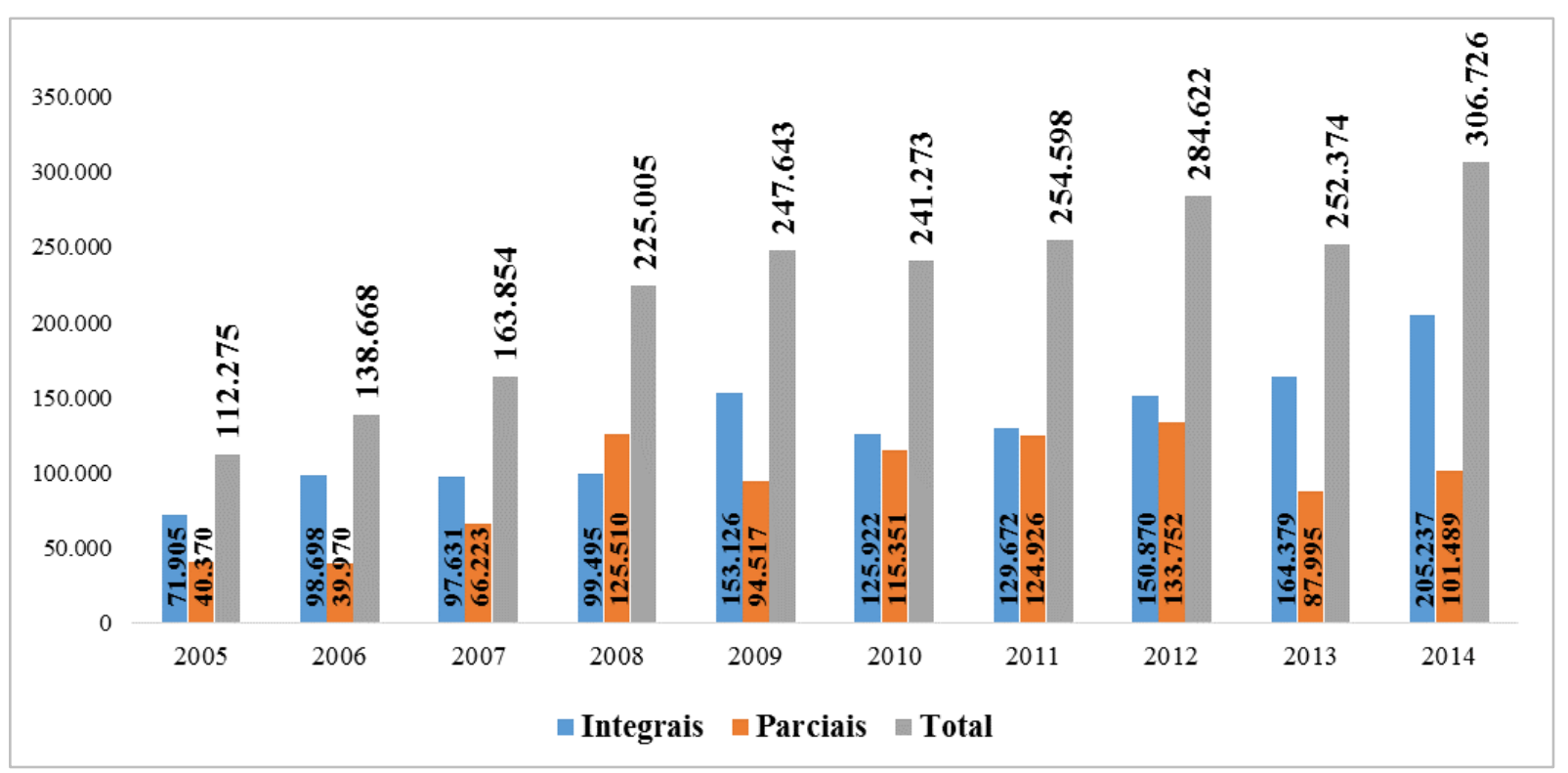

Fonte: SisProUni (BRASIL, 2015h). Bolsas ProUni 2005-2\%/2014.

Elaboração própria.

Obs.: os valores anuais não são acumulados.

A Tabela 7 expõe o número de bolsas ofertadas a cada processo seletivo, e também o número de inscritos nos mesmos períodos. É possível perceber que os processos seletivos de primeiro semestre registram maior número de bolsas ofertadas e também de inscrições. A relação estabelecida entre o número de inscritos e o número de bolsas ofertadas não tem apontado uma tendência de aumento ou decréscimo com o passar dos anos, mas é sempre maior nos processos seletivos do primeiro semestre; especialmente os de 2006, 2008 e 2011, em que se registrou uma concorrência de 8,66, 8,06 e 9,41 inscritos por bolsa, respectivamente. 
Tabela 7 - Número de bolsas ofertadas e número de inscritos no ProUni por processo seletivo.

Brasil, 2005-2014

\begin{tabular}{cccc}
\hline $\begin{array}{c}\text { Processo } \\
\text { Seletivo }\end{array}$ & $\begin{array}{c}\text { Bolsas } \\
\text { ofertadas }\end{array}$ & $\begin{array}{c}\text { Número de } \\
\text { Inscritos }\end{array}$ & $\begin{array}{c}\text { Relação } \\
\text { Inscritos/Bolsas }\end{array}$ \\
\hline $\mathbf{1 / 2 0 0 5}$ & 112.275 & 422.531 & 3,76 \\
$\mathbf{1} / \mathbf{2 0 0 6}$ & 91.609 & 793.436 & 8,66 \\
$\mathbf{2 / 2 0 0 6}$ & 47.059 & 200.969 & 4,27 \\
$\mathbf{1 / 2 0 0 7}$ & 108.642 & 483.266 & 4,45 \\
$\mathbf{2 / 2 0 0 7}$ & 55.212 & 185.295 & 3,36 \\
$\mathbf{1 / 2 0 0 8}$ & 106.134 & 855.734 & 8,06 \\
$\mathbf{2 / 2 0 0 8}$ & 118.871 & 208.181 & 1,75 \\
$\mathbf{1 / 2 0 0 9}$ & 156.416 & 608.143 & 3,89 \\
$\mathbf{2 / 2 0 0 9}$ & 91.227 & 380.935 & 4,18 \\
$\mathbf{1 / 2 0 1 0}$ & 165.428 & 1.177 .540 & 7,12 \\
$\mathbf{2 / 2 0 1 0}$ & 75.845 & 232.726 & 3,07 \\
$\mathbf{1 / 2 0 1 1}$ & 162.491 & 1.529 .299 & 9,41 \\
$\mathbf{2 / 2 0 1 1}$ & 92.107 & 460.745 & 5,00 \\
$\mathbf{1 / 2 0 1 2}$ & 194.311 & 1.208 .398 & 6,22 \\
$\mathbf{2 / 2 0 1 2}$ & 90.311 & 456.973 & 5,06 \\
$\mathbf{1 / 2 0 1 3}$ & 162.329 & 1.032 .873 & 6,36 \\
$\mathbf{2 / 2 0 1 3}$ & 90.045 & 436.941 & 4,85 \\
$\mathbf{1 / 2 0 1 4}$ & 191.625 & 1.259 .285 & 6,57 \\
$\mathbf{2 / 2 0 1 4}$ & 115.101 & 653.992 & 5,68 \\
\hline
\end{tabular}

Fonte: SisProUni (BRASIL, 2015h).

Elaboração Própria.

Obs.: não houve processo seletivo em 2/2005.

O website oficial do ProUni também nos fornece algumas informações sobre o perfil dos bolsistas, no período de 2005 a 2014. O total de bolsistas ${ }^{54}$ apresentado é de 1.497.225. Destes, conforme mostra o Gráfico 7, a maioria é do sexo feminino (790.668 bolsistas ou 53\%), quadro que se assemelha à realidade da educação superior brasileira, cujo contingente de mulheres é sempre maior (conforme consta no Censo da Educação Superior 2013 do INEP, $55,5 \%$ das matrículas eram de mulheres, e 44,5\% de homens).

\footnotetext{
${ }^{54}$ Não foram encontradas informações, na fonte pesquisada do MEC, acerca do cálculo do número de bolsistas informado (se são bolsas efetivamente ocupadas, e/ou se é o acumulado entre 2005 e 2014, por exemplo). De todo modo, o cálculo não corresponde ao total de bolsas ofertadas no período de 2005 e 2014, que foi de 2.227.038. O número de bolsas ativas somente em 2014, de acordo com Ristoff (2014), foi de cerca de 600 mil.
} 
Gráfico 7 - Número de bolsistas ProUni por sexo.

Brasil, 2005-2014

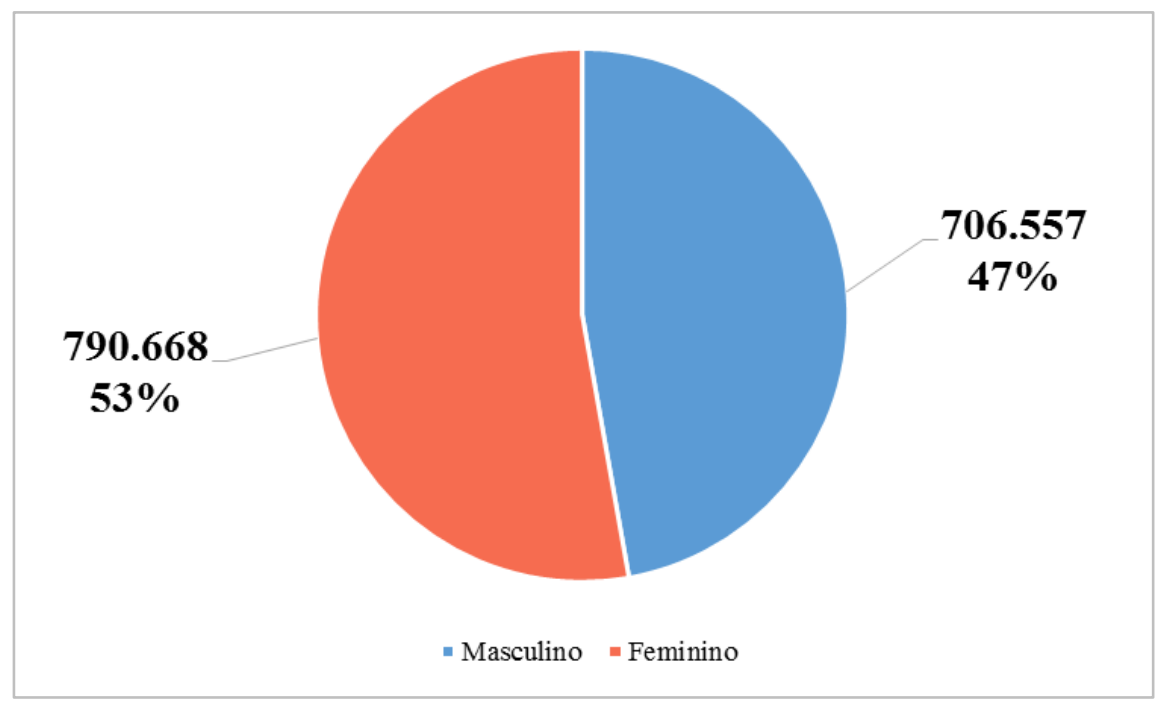

Fonte: SisProUni (BRASIL, 2015h). Bolsistas ProUni 2005-2\%2014.

Elaboração própria.

$\mathrm{Na}$ desagregação por raça/cor (Gráfico 8), a grande maioria dos bolsistas são brancos (46\%), seguidos por pardos $(38 \%)$ e pretos $(13 \%)$. Se compararmos essas informações com dados populacionais, obtidos pelo Censo Demográfico 2010 (IBGE), nota-se que a distribuição por raça/cor no Brasil é de: 47,7\% brancos; $43,1 \%$ pardos e 7,6\% negros. Ou seja, estes últimos apresentam distribuição superior entre os bolsistas do ProUni (em que representam 13\% dos bolsistas), do que no conjunto da população brasileira.

Gráfico 8 - Número de bolsistas ProUni por raça/cor.

Brasil, 2005-2014

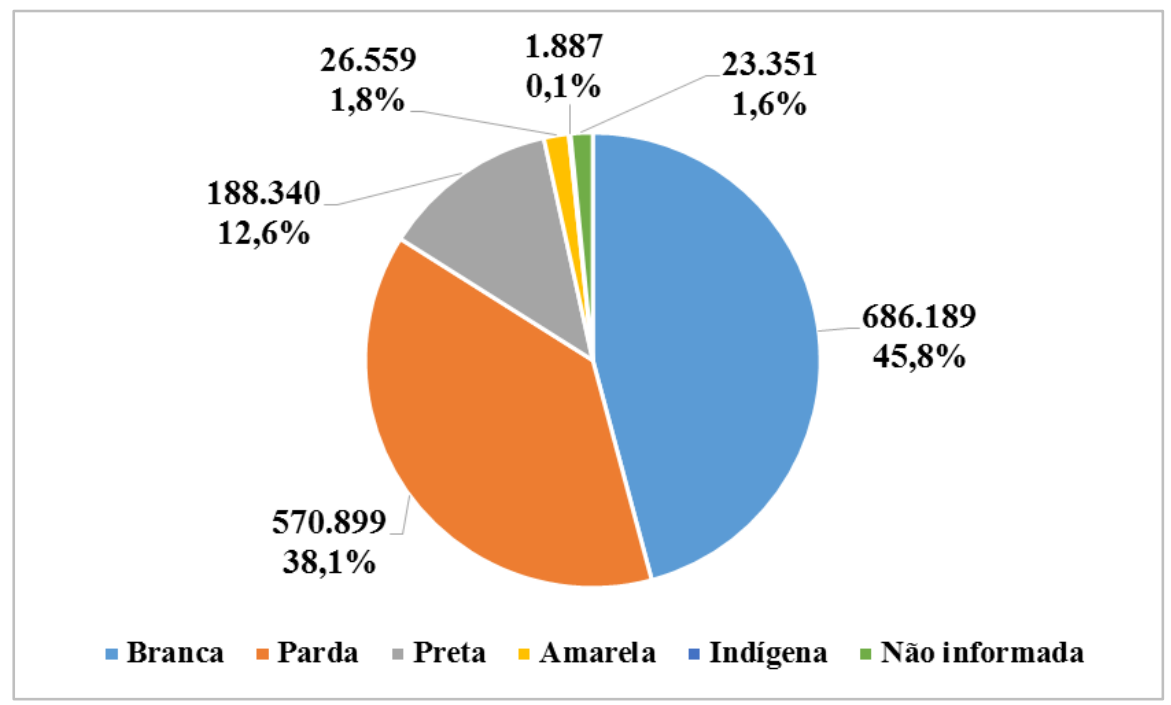

Fonte: SisProUni (BRASIL, 2015h). Bolsistas ProUni 2005-2²014.

Elaboração própria. 
A PNAD-IBGE de 2014 apontou que havia $42 \%$ de pardos e pretos que declararam estar cursando o ensino de nível superior no Brasil, proporção que tem aumentado nos últimos anos. Sobre esse assunto, Ristoff $(2013,2014)$ e Barreyro e Costa (2015) relacionam o aumento de pardos e pretos nas universidades (movimento também associado à redução de estudantes brancos) ao reflexo de políticas visando a inclusão social como o ProUni, o Fies e a adoção de políticas de cotas nas universidades públicas. De fato, percebe-se entre os bolsistas do ProUni que o percentual de pardos e pretos é superior ao de brancos, somando $51 \%$ no período analisado.

Outros recortes obtidos sobre os beneficiários do ProUni também apontam que apenas $1 \%$ dos bolsistas (12.225) são professores da educação básica pública; outros $1 \%$ (10.340) são portadores de deficiência.

Com relação à modalidade de ensino dos bolsistas (Gráfico 9), a grande maioria se situa como realizando os estudos no modo presencial (1.273.322 ou 85\%). Apenas 15\% (223.903) cursam no modo EaD, ou seja, na Educação a Distância.

Gráfico 9 - Número de bolsistas ProUni por modalidade de ensino.

Brasil, 2005-2014

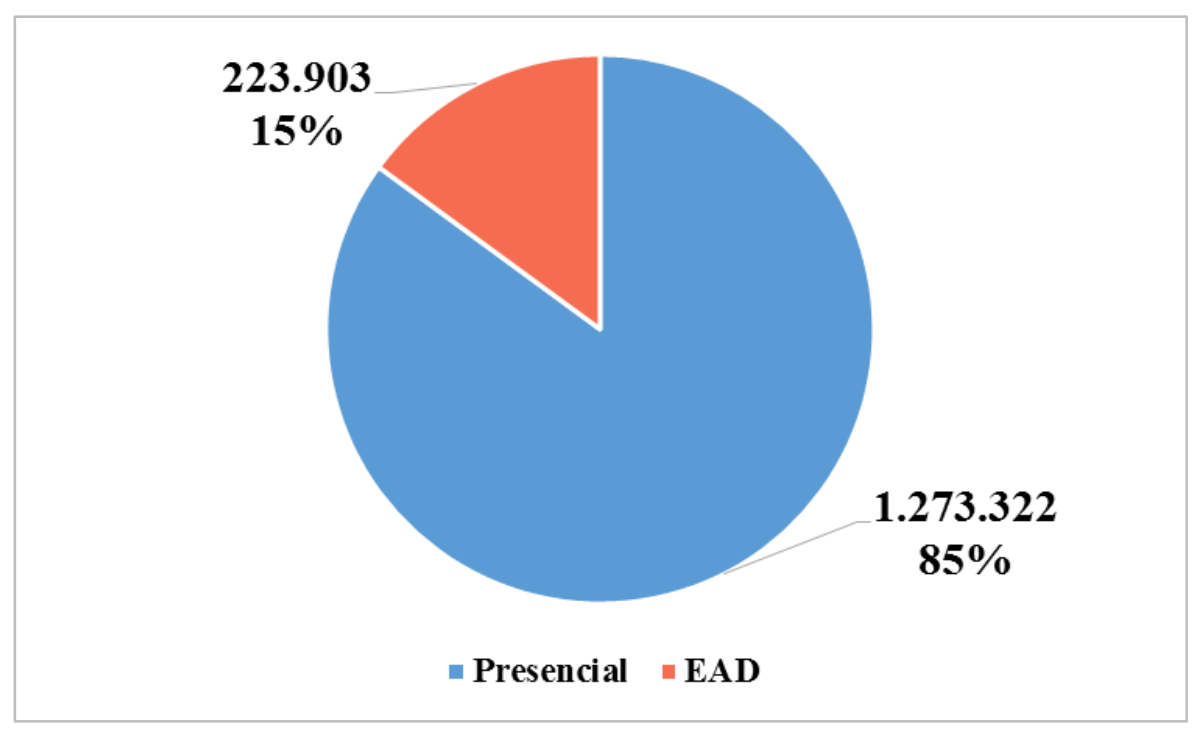

Fonte: SisProUni (BRASIL, 2015h). Bolsistas ProUni 2005-2\%/2014.

Elaboração própria. 
Com relação ao turno (Gráfico 10), já no recorte realizado apenas por cursos presenciais, a maioria dos bolsistas encontra-se no período noturno (74\%), seguido pelo matutino (19\%).

Gráfico 10 - Número de bolsistas ProUni por turno (cursos presenciais).

Brasil, 2005-2014

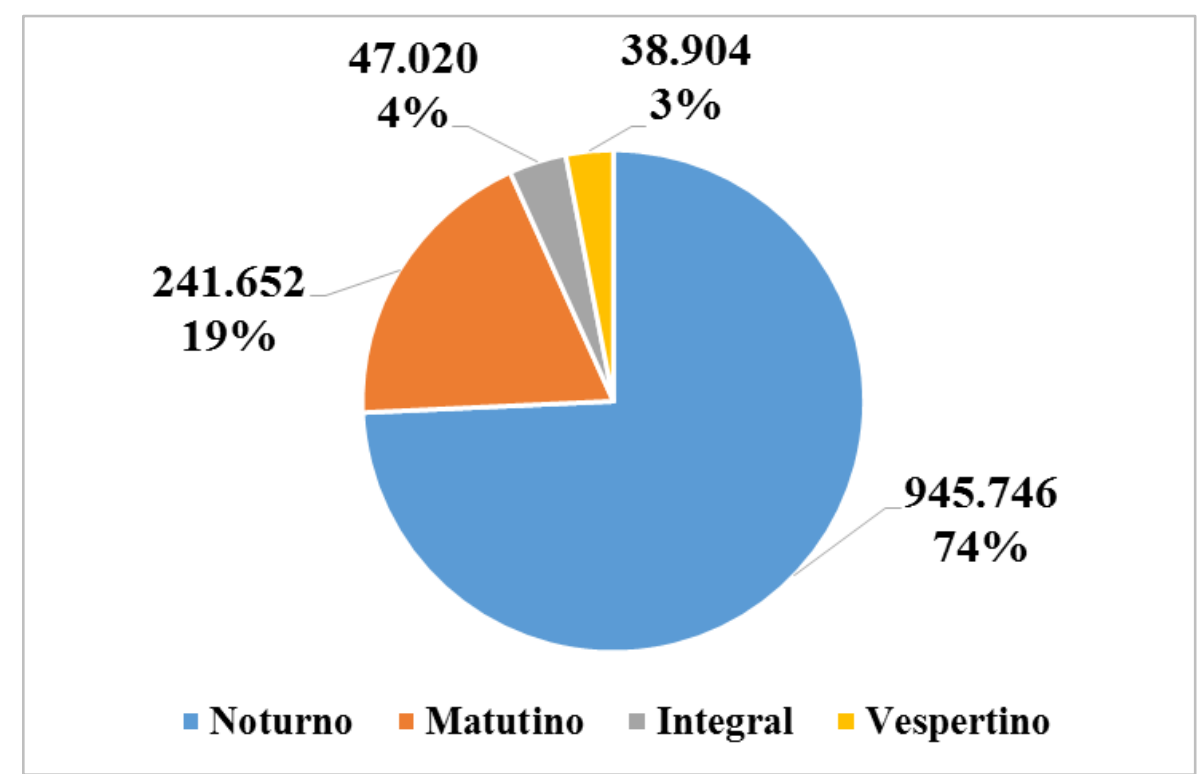

Fonte: SisProUni (BRASIL, 2015h). Bolsistas ProUni 2005-2\%/2014.

Elaboração própria.

O Gráfico 11 nos propicia informações sobre a categoria administrativa das Instituições de Ensino Superior em que os bolsistas ProUni foram distribuídos durante o período. Embora os números absolutos não sejam divulgados na fonte, é possível visualizar que $57 \%$ dessas instituições são entidades com fins lucrativos, representando as mais propícias a aderirem ao Programa - pois, conforme mencionado anteriormente, são as que obtém maior ganho por meio das isenções fiscais. Outras $26 \%$ são entidades beneficentes de assistência social, e 17\% são sem fins lucrativos não beneficentes. 
Gráfico 11 - Bolsistas ProUni por categoria administrativa da Instituição de Ensino Superior (em \%). Brasil, 2005-2014.

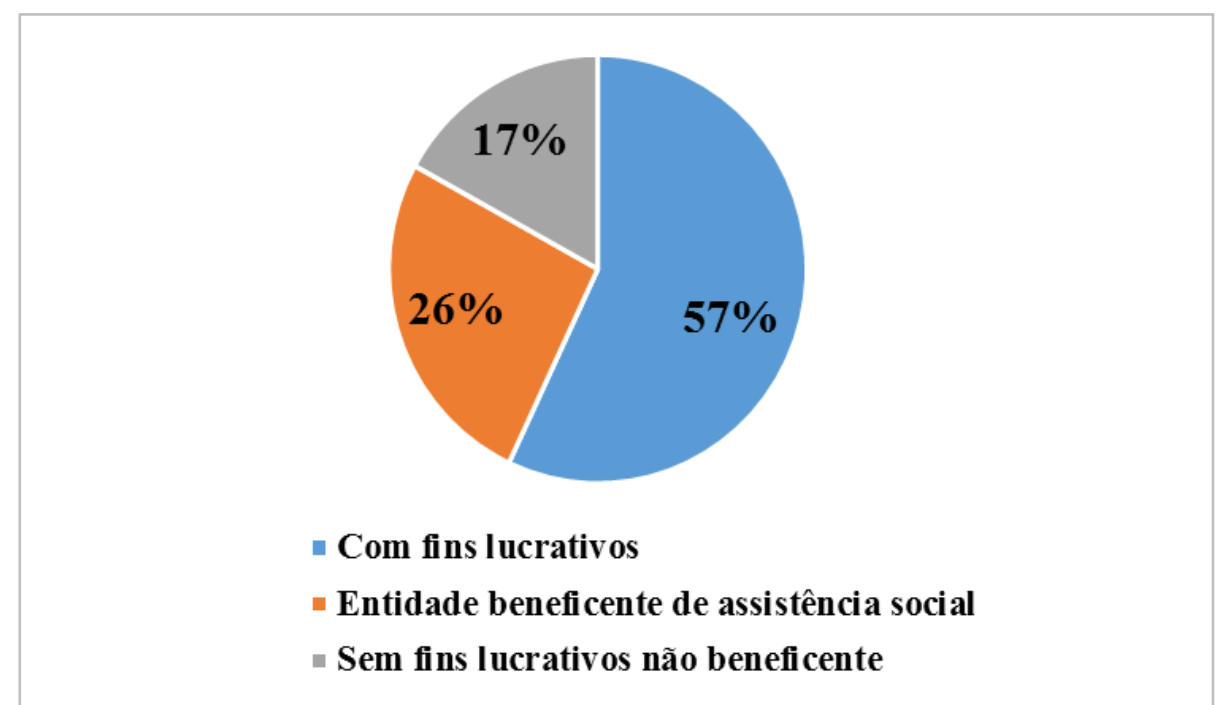

Fonte: SisProUni (BRASIL, 2015h). Bolsistas ProUni 2005-2\%/2014. Elaboração própria.

Com relação aos dados gerais sobre a regionalização dos bolsistas, nota-se no Gráfico 12 que a maior parte (50\% ou 755.889 bolsistas) localiza-se na região Sudeste. Com relação às outras regiões, a segunda com o maior número de bolsistas é a Sul (19\% ou 281.826 bolsistas), seguida da região Nordeste (15\% ou 229.865 bolsistas). Este resultado, de certa maneira, acompanha a distribuição do total de matrículas no setor privado educacional brasileiro (estudantes em geral). Segundo os dados do Censo da Educação Superior 2013, 53\% das matrículas em instituições privadas encontravam-se na região Sudeste; 18\% no Nordeste, 14\% no Sul, $10 \%$ no Centro-Oeste e 5\% no Norte do país (BRASIL, 2015b). 
Gráfico 12 - Número de bolsistas ProUni por grandes regiões brasileiras.

Brasil, 2005-2014

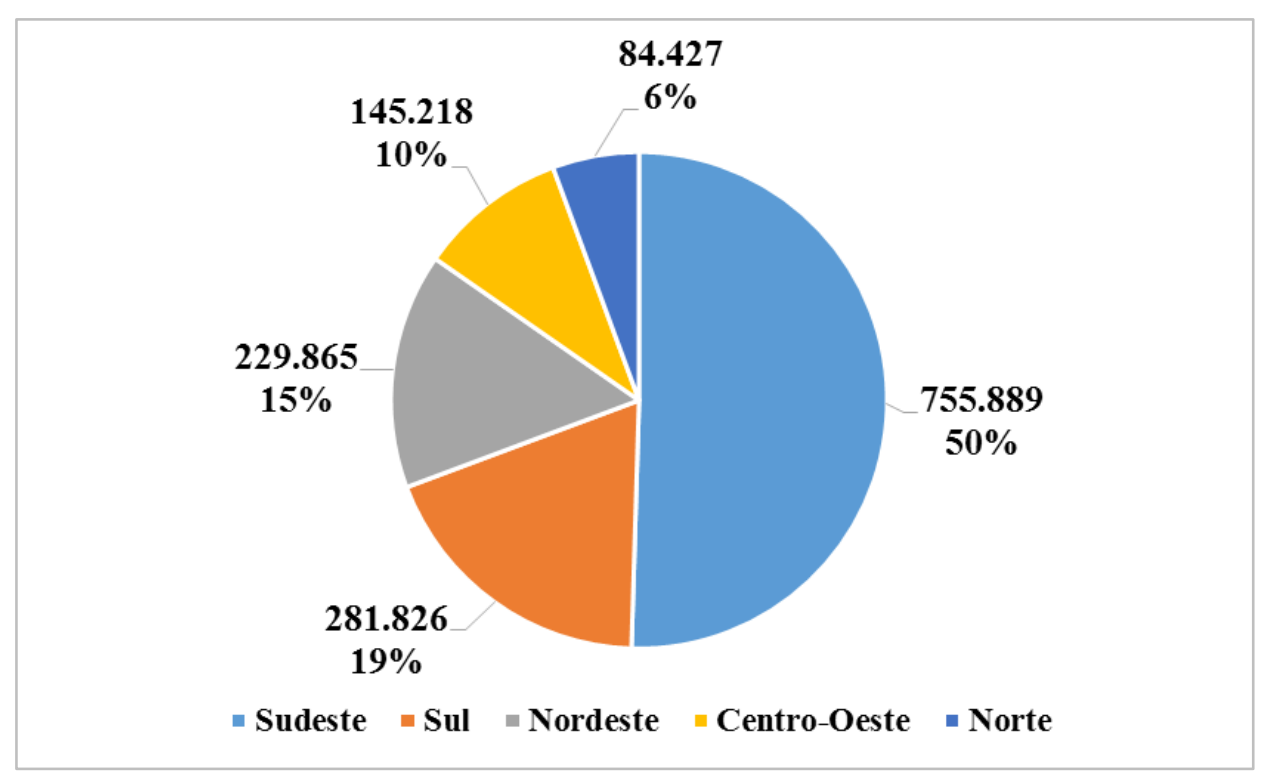

Fonte: SisProUni (BRASIL, 2015h). Bolsistas ProUni 2005-2\%/2014.

Elaboração própria.

Ainda assim, a partir dessas estatísticas oficiais, foi possível obter apenas um pequeno retrato da realidade do Programa Universidade para Todos. Muitas informações ainda permanecem sem divulgação, sendo esta uma das dificuldades apontadas por autores como Catani, Hey e Gilioli (2006), Carvalho (2006) e Almeida (2010, 2012). Justamente a escassez de estatísticas mais específicas e séries históricas, como por exemplo a respeito das IES e dos cursos participantes, perfil socioeconômico detalhado dos bolsistas, desempenho dos bolsistas, taxas de evasão, etc., acaba dificultando um olhar mais detalhado sobre a realidade do Programa.

No entanto, a instituição da Lei de Acesso à Informação ( $n^{\circ} 12.527$, de 18 de novembro de 2011) tornou possível obter, desde então, novas informações e estatísticas sobre diversas políticas públicas, entre elas o ProUni, por meio de solicitação ${ }^{55}$ ao órgão responsável (no caso, o MEC). Foram solicitadas informações relativas aos processos seletivos do segundo semestre de 2013 e primeiro semestre de 2014, portanto, dados referentes à oferta de bolsas. As variáveis solicitadas referem-se às IES e aos cursos ofertados, tipos de bolsa, turnos, regionalização (por Unidade Federativa e município), entre outras.

\footnotetext{
${ }^{55} \mathrm{O}$ processo de solicitação para a obtenção dos dados é realizado no Sistema Eletrônico do Serviço de Informação ao Cidadão (E-SIC), de forma online.
} 
Portanto, a partir da constatação dessa possibilidade de ampliação da análise, a pesquisa prosseguiu com a exploração das informações obtidas. Alguns dos dados serão detalhados na próxima seção, em que se centrará a análise mais aprofundada sobre o alcance do ProUni.

\subsection{O ProUni: processos seletivos de 2013 e 2014}

Nesta seção, serão apresentados dados sobre o Programa Universidade para Todos focalizados nos processos seletivos de 2/2013 (segundo semestre de 2013) e 1/2014 (primeiro semestre de 2014). O aprofundamento analítico nesta seção foi possível, conforme mencionado anteriormente, por conta da possibilidade de acesso a estas informações via Lei de Acesso à Informação. Assim, foi possível obter dados mais específicos sobre o ProUni, e com maior nível de desagregação, especialmente sobre o número de cursos e IES participantes, turnos, modalidades de ensino, regionalização, etc. Vale ressaltar que a identificação dos alunos continuou sendo preservada.

É importante mencionar que se preferiu, inicialmente, apresentar os dados dos dois processos seletivos em separado; apesar de possuírem algumas características semelhantes, como será visto a seguir na análise, a seleção do segundo semestre é muito menor, em termos de número de bolsas, do que a do primeiro semestre. Conforme constatado nas estatísticas gerais sobre o ProUni, a situação do processo seletivo ser mais abrangente no primeiro semestre tem sido uma constante desde o início dos processos seletivos.

Além disso, pelo grande volume de dados a serem trabalhados, foi realizado um recorte geográfico para a análise: algumas informações nacionais e outras focalizadas por estado e município (neste caso, foram escolhidos o estado de São Paulo o município de São Paulo-SP, por possuírem o maior número de bolsas ofertadas e de bolsistas desde o início da política).

\subsubsection{ProUni: bolsas ofertadas no Brasil}

O número de bolsas ofertadas, no processo seletivo do segundo semestre de 2013 (2/2013), foi de 90.045 no total do país. No processo seletivo 1/2014 (primeiro semestre de 2014) esse número foi bem maior, como costuma ser nas seleções do primeiro semestre de cada ano, totalizando 191.625 bolsas (Tabela 8). 
Tabela 8 - Número de bolsas ProUni ofertadas nos processos seletivos 2/2013 e 1/2014.

Brasil e UFs

\begin{tabular}{ccc|ccc}
\hline \multicolumn{3}{c|}{$\mathbf{2 / 2 0 1 3}$} & & \multicolumn{3}{|c}{$\mathbf{1 / 2 0 1 4}$} \\
\hline UF & № de bolsas & $\mathbf{\%}$ & UF & № de bolsas & $\mathbf{\%}$ \\
\hline SP & 23.540 & $26,1 \%$ & SP & 64.327 & $33,6 \%$ \\
MG & 12.597 & $14,0 \%$ & MG & 19.584 & $10,2 \%$ \\
PR & 6.551 & $7,3 \%$ & PR & 16.572 & $8,6 \%$ \\
RJ & 5.587 & $6,2 \%$ & RS & 12.981 & $6,8 \%$ \\
RS & 5.187 & $5,8 \%$ & SC & 10.803 & $5,6 \%$ \\
SC & 4.439 & $4,9 \%$ & BA & 8.929 & $4,7 \%$ \\
BA & 4.336 & $4,8 \%$ & RJ & 8.261 & $4,3 \%$ \\
DF & 4.083 & $4,5 \%$ & GO & 5.899 & $3,1 \%$ \\
GO & 3.667 & $4,1 \%$ & DF & 5.672 & $3,0 \%$ \\
MA & 2.612 & $2,9 \%$ & PE & 4.516 & $2,4 \%$ \\
CE & 2.408 & $2,7 \%$ & MT & 3.849 & $2,0 \%$ \\
PE & 2.162 & $2,4 \%$ & CE & 3.541 & $1,8 \%$ \\
PA & 1.655 & $1,8 \%$ & PA & 3.414 & $1,8 \%$ \\
MT & 1.311 & $1,5 \%$ & ES & 3.211 & $1,7 \%$ \\
AM & 1.250 & $1,4 \%$ & AM & 2.707 & $1,4 \%$ \\
ES & 1.247 & $1,4 \%$ & MA & 2.624 & $1,4 \%$ \\
PB & 1.101 & $1,2 \%$ & MS & 2.404 & $1,3 \%$ \\
MS & 905 & $1,0 \%$ & PB & 2.028 & $1,1 \%$ \\
AL & 801 & $0,9 \%$ & RN & 1.804 & $0,9 \%$ \\
RN & 792 & $0,9 \%$ & RO & 1.715 & $0,9 \%$ \\
RO & 789 & $0,9 \%$ & AL & 1.369 & $0,7 \%$ \\
SE & 749 & $0,8 \%$ & TO & 1.307 & $0,7 \%$ \\
PI & 724 & $0,8 \%$ & PI & 1.300 & $0,7 \%$ \\
TO & 583 & $0,6 \%$ & SE & 1.005 & $0,5 \%$ \\
AC & 451 & $0,5 \%$ & AP & 964 & $0,5 \%$ \\
AP & 314 & $0,3 \%$ & AC & 540 & $0,3 \%$ \\
RR & 204 & $0,2 \%$ & RR & 299 & $0,2 \%$ \\
\hline Total & $\mathbf{9 0 . 0 4 5}$ & $\mathbf{1 0 0 , 0 \%}$ & Total & $\mathbf{1 9 1 . 6 2 5}$ & $\mathbf{1 0 0 , 0 \%}$ \\
\hline Fo & $-S 1 C / M i s 610$ & & &
\end{tabular}

Fonte: E-SIC / Ministério da Educação.

Elaboração própria.

Em termos regionais, nos dois processos seletivos, o estado de São Paulo concentra o maior número de bolsas (26,1\% no segundo semestre de 2013 e 33,6\% no primeiro semestre de 2014). Há uma concentração em segundo lugar no estado de Minas Gerais, com 14\% e 10,2\% respectivamente, e Paraná (7,3\% e 8,6\% respectivamente), nos dois processos seletivos, revelando distribuição semelhante das bolsas. Também figuram nas primeiras posições os estados do Rio de Janeiro, Rio Grande do Sul e Santa Catarina. Observa-se, então, um acúmulo de bolsas ofertadas nas regiões Sudeste e Sul do país, conforme observado anteriormente nas estatísticas gerais do ProUni, acerca dos números acumulados desde a sua criação. Por outro lado, os estados da região Norte (Roraima, Acre e Amapá) aparecem nos dois levantamentos com o menor número de bolsas oferecidas, somando no máximo $1 \%$ juntos. 


\subsubsection{ProUni: bolsas ofertadas no estado de São Paulo}

O estado de São Paulo possui participação bastante representativa nos processos seletivos, comportando o maior número de bolsas ProUni ofertadas desde a sua criação (cerca de um terço das bolsas ofertadas no país). Por esta razão, a partir desse momento a análise será centralizada nos dados do estado, posteriormente também afunilada para o nível de município (São Paulo-SP), por ser também muito representativo em número de bolsas e por permitir uma análise mais desagregada e com mais variáveis.

Os Gráficos 13 e 14, a seguir, identificam os 10 primeiros municípios do estado de São Paulo classificados com maior oferta de bolsas nos processos seletivos de 2013 e 2014. Foi observado que a maior concentração de bolsas do estado está, evidentemente, no município de São Paulo, que concentrou a oferta de 42,6\% (10.038) do total de bolsas do segundo semestre de 2013, e 41,7\% (26.841) do primeiro semestre de 2014.

No segundo semestre de 2013 (Gráfico 13), o destaque fica para uma concentração maior nos municípios da Região Metropolitana de São Paulo, como Guarulhos (3,1\%), Mogi das Cruzes (2,1\%), São Bernardo do Campo (2,0\%) e Santo André (1,8\%). Já os municípios de Campinas (4,9\%), Presidente Prudente (4,3\%), Araras $(2,9 \%)$, Bauru $(2,6 \%)$ e Sorocaba $(2,2 \%)$, alguns dos mais populosos nas regiões interioranas do estado, e também conhecidos por serem cidades universitárias, lideram o processo seletivo do primeiro semestre de 2014 (Gráfico 14). 
Gráfico 13 - Principais municípios do estado de São Paulo com maior número de bolsas ProUni ofertadas no processo seletivo 2/2013 (em \%).

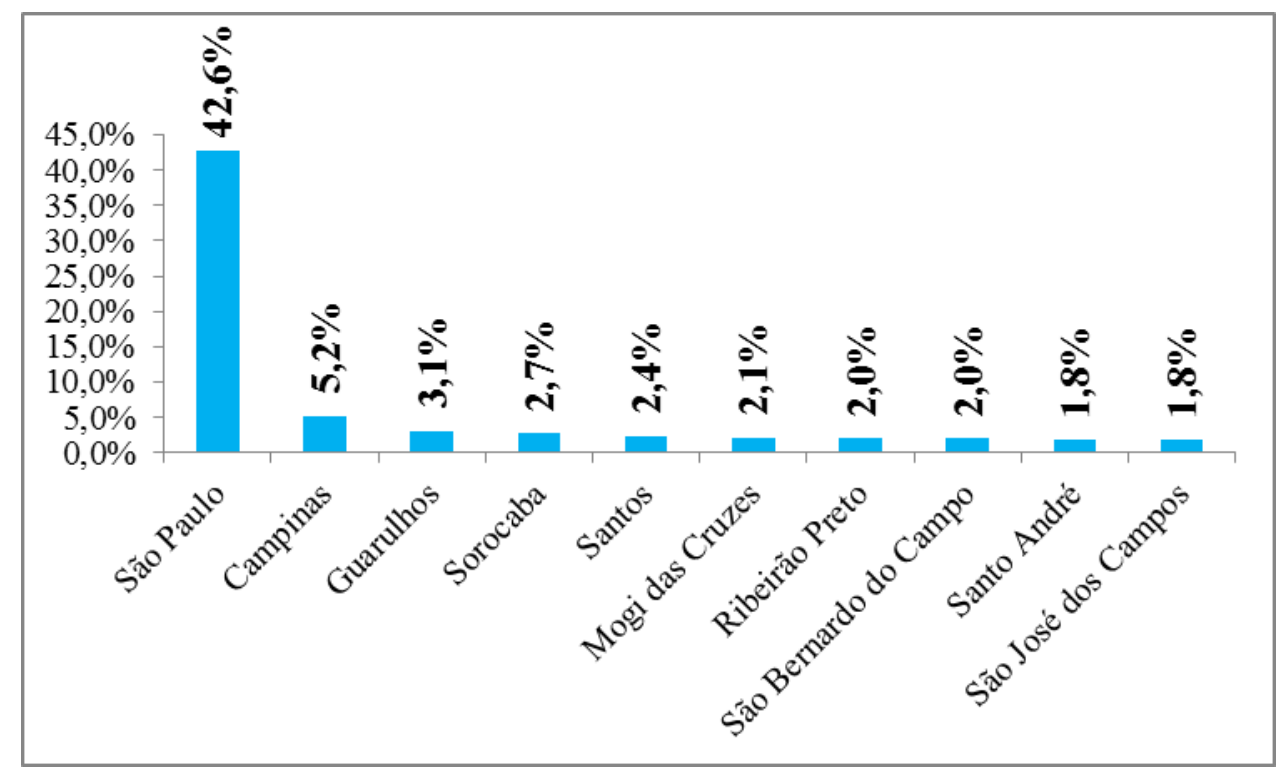

Fonte: E-SIC / Ministério da Educação.

Elaboração própria.

Gráfico 14 - Principais municípios do estado de São Paulo com maior número de bolsas ProUni ofertadas no processo seletivo 1/2014 (em \%).

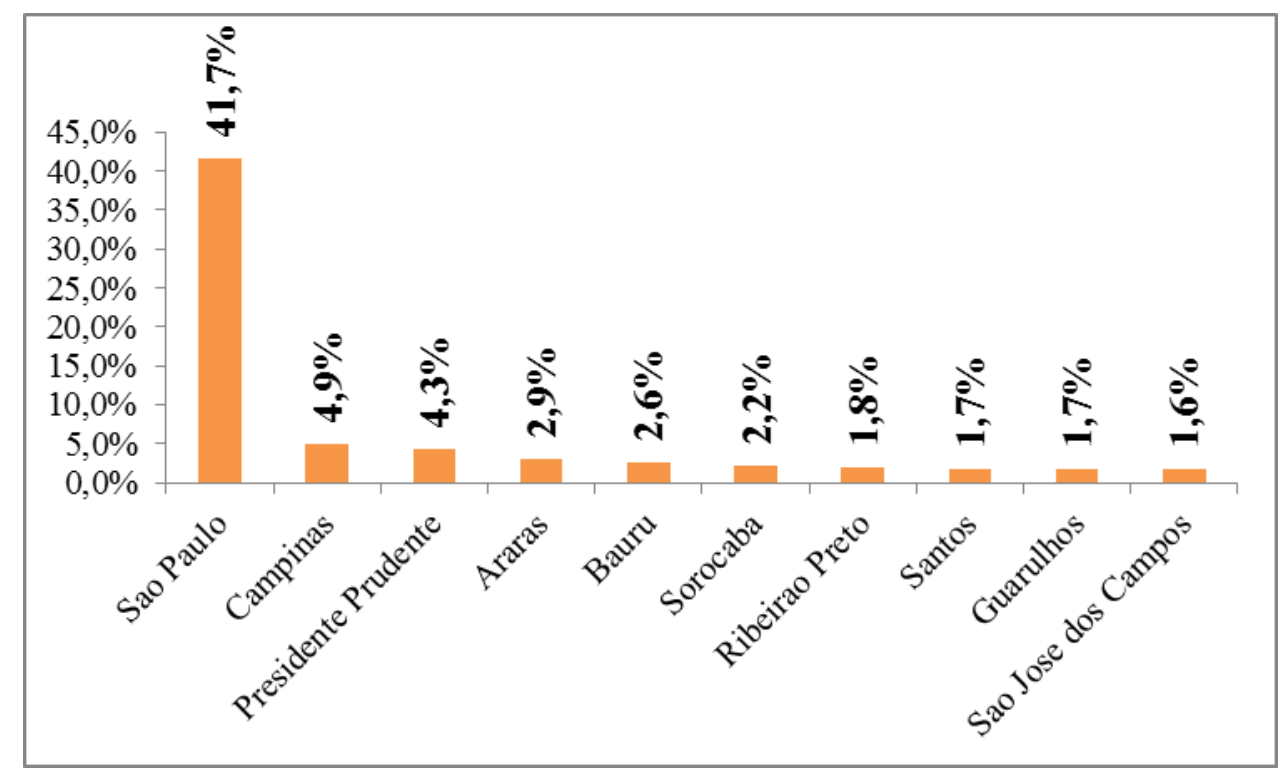

Fonte: E-SIC / Ministério da Educação.

Elaboração própria.

A Tabela 9 permite a identificação das 15 primeiras Instituições de Ensino Superior do estado de São Paulo classificadas com a maior oferta de bolsas no processo seletivo 1/2014. Os dados revelam um quadro interessante, em que a primeira instituição da lista é a Universidade São Judas Tadeu (USTJ), concentrando sozinha 7.683 vagas, ou 11,9\% do total ofertado no 
semestre. A lista é tomada por outros grandes grupos universitários, como a Universidade Paulista (UNIP), com 6.558 vagas ou 10,2\%, e Universidade Nove de Julho (UNINOVE), com 3.033 vagas ou 4,7\%, além de instituições do grupo Anhanguera Educacional (Centro Universitário Anhanguera de São Paulo, Universidade Anhanguera - Uniderp, UNOPAR). Juntas, as 15 primeiras instituições representam 33.582 bolsas, ou aproximadamente $52 \%$ do total de oferta do semestre, revelando um quadro de grande concentração de bolsas em poucas instituições. No total, 72 IES diferentes ofereceram bolsas neste processo seletivo.

Tabela 9 - Principais Instituições de Ensino Superior que mais ofertaram bolsas do ProUni no processo seletivo $1 / 2014$

Estado de São Paulo, 2014

\begin{tabular}{lcc}
\hline \multicolumn{1}{c}{ Instituição de Ensino Superior } & $\begin{array}{c}\text { Número de } \\
\text { bolsas } \\
\text { ofertadas }\end{array}$ & $\begin{array}{c}\text { \% do total } \\
\text { ofertado no } \\
\text { semestre* }\end{array}$ \\
\hline Universidade São Judas Tadeu (USJT) & 7.683 & $\mathbf{1 1 , 9 \%}$ \\
Universidade Paulista (UNIP) & 6.558 & $\mathbf{1 0 , 2 \%}$ \\
Universidade Nove de Julho (UNINOVE) & 3.033 & $\mathbf{4 , 7 \%}$ \\
Universidade Anhanguera - Uniderp & 2.694 & $\mathbf{4 , 2 \%}$ \\
Universidade do Oeste Paulista (UNOESTE) & 2.219 & $\mathbf{3 , 4 \%}$ \\
Centro Universitário Herminio Ometto (UNIARARAS) & 1.870 & $\mathbf{2 , 9 \%}$ \\
Universidade Ibirapuera (UNIB) & 1.830 & $\mathbf{2 , 8 \%}$ \\
Universidade Anhembi Morumbi (UAM) & 1.445 & $\mathbf{2 , 2 \%}$ \\
Pontifícia Universidade Católica de Campinas (PUC-CAMPINAS) & 1.196 & $\mathbf{1 , 9 \%}$ \\
Faculdade São Paulo (FACSP) & 1.000 & $\mathbf{1 , 6 \%}$ \\
Centro Universitário das Faculdades Metropolitanas Unidas (FMU) & 980 & $\mathbf{1 , 5 \%}$ \\
Universidade do Sagrado Coração (USC) & 811 & $\mathbf{1 , 3 \%}$ \\
Universidade Cruzeiro do Sul (UNICSUL) & 785 & $\mathbf{1 , 2 \%}$ \\
Centro Universitário Anhanguera de São Paulo & 756 & $\mathbf{1 , 2 \%}$ \\
Universidade Norte do Paraná (UNOPAR) & 722 & $\mathbf{1 , 1 \%}$ \\
\hline
\end{tabular}

Fonte: E-SIC / Ministério da Educação.

Elaboração própria.

*Obs.: a soma das 15 instituições não reflete o total ofertado no semestre.

Diante deste quadro, torna-se necessário resgatar o contexto discutido no Capítulo 1, no qual foi verificado que o setor de educação superior brasileiro é tomado por um processo de concentração de grandes empresas educacionais, constantemente permeadas por fusões, aquisições e incorporações (SGUISSARDI, 2008, 2014; MANCEBO, VALE e MARTINS, 2015), chegando até mesmo a um processo de oligopolização (OLIVEIRA, 2009; 
SGUISSARDI, 2014). Desde o início dos anos 1990, muitas Instituições de Ensino Superior privadas profissionalizaram sua gestão, com algumas, inclusive, investindo capital na Bolsa de Valores, passando a realizar aquisições e investimentos em todo o território nacional (SÉCCA e LEAL, 2009).

A educação superior se tornou "um próspero e afluente mercado, cuja faceta mais importante refere-se à penetração do capital financeiro na educação e a consequente internacionalização da oferta educacional" (OLIVEIRA, 2009, p. 742). Alguns casos recentes envolvendo instituições que estão na lista são: a Universidade Anhembi Morumbi (UAM), da $8^{\text {a }}$ posição, cujo grupo americano Laureate Education adquiriu parte de seu capital em 2005 (OLIVEIRA, 2009). O Grupo Anhanguera Educacional, do qual fazem parte a Universidade Anhanguera - Uniderp e o Centro Universitário Anhanguera de São Paulo, que aparecem na $4^{\text {a }}$ e na $14^{a}$ posição, respectivamente, já era um dos maiores grupos educacionais do Brasil; em 2014, anunciou uma fusão, estabelecendo, hoje, o maior grupo privado educacional do Brasil e um dos maiores do mundo, o Kroton, que reúne 1,1 milhão de alunos, e é a $17^{\mathrm{a}}$ maior empresa da Bovespa em termos de valor de mercado (GUTIERREZ, 2014; KROTON, 2015). Além da Anhanguera, outros nomes como Pitágoras, Unime, Uniasselvi, Unic e Fama também fazem parte do Kroton. A Universidade Norte do Paraná (UNOPAR), que aparece na lista do ProUni na $15^{a}$ posição, também faz parte do mesmo grupo, e é a maior instituição de Ensino a Distância do Brasil, segundo dados do Censo da Educação Superior 2013 (BRASIL, 2015b).

Certamente, os dados das instituições que oferecem cursos pelo ProUni reforçam esse quadro de concentração institucional, podendo apontar, consequentemente, para a pouca diversificação do ensino oferecido. O processo de transformação da educação superior em mercadoria, conforme observado anteriormente na literatura, é um quadro que encontra ecos nas reflexões de que o ProUni facilita e reforça o processo de concentração e até de uma possível oligopolização dessas instituições, por meio dos benefícios concedidos a elas na forma de isenções fiscais.

\subsubsection{ProUni: bolsas ofertadas no município de São Paulo-SP}

Nesta seção, será dado prosseguimento analisando os dados do município de São Paulo, desta vez com informações em maior nível de desagregação. Para um estudo mais aprofundado, serão analisadas variáveis como: IES e cursos, áreas de conhecimento, tipos de bolsa (integral 
ou parcial), turno/modalidade de ensino (presencial e a distância). Por meio dessas variáveis, foi possível realizar uma grande quantidade de cruzamentos.

O município de São Paulo ofertou 10.038 bolsas ProUni no segundo semestre de 2013, que representam 42,6\% do estado, e 26.841 bolsas no primeiro semestre de 2014, representando 41,7\% do estado (Tabela 10).

Tabela 10 - Número de bolsas ProUni ofertadas nos processos seletivos 2/2013 e 1/2014, por tipo de bolsa

Município de São Paulo-SP

\begin{tabular}{ccc}
\hline $\begin{array}{c}\text { Tipo de } \\
\text { bolsa }\end{array}$ & $\begin{array}{c}\text { Total de bolsas } \\
\text { ofertadas } \\
\mathbf{2 / 2 0 1 3}\end{array}$ & $\begin{array}{c}\text { Total de bolsas } \\
\text { ofertadas } \\
\mathbf{1 / 2 0 1 4}\end{array}$ \\
\hline Parcial & 4.564 & 16.041 \\
$\%$ & $45,5 \%$ & $59,8 \%$ \\
\hline Integral & 5.474 & 10.800 \\
$\%$ & $54,5 \%$ & $40,2 \%$ \\
\hline Total & $\mathbf{1 0 . 0 3 8}$ & $\mathbf{2 6 . 8 4 1}$ \\
\hline & $\mathbf{1 0 0 \%}$ & $\mathbf{1 0 0 \%}$ \\
\hline
\end{tabular}

Fonte: E-SIC / Ministério da Educação.

Elaboração própria

$\mathrm{Na}$ Tabela 10 é possível identificar ainda que, no processo seletivo do segundo semestre de 2013, 54,5\% das bolsas foram integrais (5.474), e 45,5\% foram parciais (4.564). No entanto, como já foi observado, o processo seletivo é sempre menor, em termos de oferecimento de bolsas, no segundo semestre.

No primeiro semestre de 2014, das 26.841 bolsas ofertadas, a maioria foi do tipo parcial, alcançando um número de 16.041 bolsas ou 59,8\% do total. As bolsas integrais alcançaram 10.800 , ou $40,2 \%$ do total. 
Tabela 11 - Número de bolsas ProUni ofertadas no processo seletivo 1/2014, por turno do curso Município de São Paulo-SP

\begin{tabular}{ccc}
\hline Turno do curso & $\begin{array}{c}\text { Número de } \\
\text { bolsas ofertadas }\end{array}$ & $\mathbf{\%}$ \\
\hline Noturno & 16.360 & $\mathbf{6 1}$ \\
Matutino & 7.923 & $\mathbf{3 0}$ \\
Curso a distância & 1.617 & $\mathbf{6}$ \\
Vespertino & 850 & $\mathbf{3}$ \\
Integral & 91 & $\mathbf{0}$ \\
\hline TOTAL & $\mathbf{2 6 . 8 4 1}$ & $\mathbf{1 0 0}$ \\
\hline
\end{tabular}

Fonte: E-SIC / Ministério da Educação.

Elaboração própria.

A Tabela 11 permite visualizar o número de bolsas ofertadas pelo ProUni, por turno do curso, no processo seletivo do primeiro semestre de 2014. A maioria dos cursos é ofertada no período noturno (61\%), o que é uma constante na educação superior brasileira, e que também propicia uma situação mais favorável a alunos de baixa renda (o público alvo do Programa), caracterizados por geralmente trabalhar além de estudar (ALMEIDA, 2012). O turno matutino vem em segundo lugar, com $30 \%$ da oferta.

É importante ressaltar, também, a baixa quantidade dos cursos de Educação a Distância, representando apenas $6 \%$ do total, pois é um segmento educacional que vem se expandindo fortemente na educação superior privada - o Censo da Educação Superior 2013 registrou cerca de $15,8 \%$ de matrículas na modalidade $\mathrm{EaD}$, ao passo que em 2003, esse tipo de matrículas representava apenas $1,3 \%$ do total (BRASIL, 2015b). De todo modo, os dados mostram que a maior parte dos cursos que ofertaram bolsas pelo ProUni nesse período foi realizada de forma presencial.

Os cursos que ofereceram bolsas pelo ProUni, segundo classificação dos 20 primeiros com maior número de oferta de bolsas em cada processo seletivo (conforme é possível visualizar nos Gráficos 15 e 16), estão visivelmente concentrados na área de Ciências Humanas (Administração, Direito e Pedagogia revezam os três primeiros lugares nos dois processos seletivos - primeiro e segundo semestres). São, exatamente, os 3 cursos com maior número de matrículas segundo o Censo da Educação Superior $2013^{56}$.

\footnotetext{
${ }^{56}$ Segundo os dados do Censo 2013 (BRASIL, 2015b), Administração: 800.114 matrículas, com participação de 11\% no total; Direito: 769.889 matrículas ou 10,5\% do total; Pedagogia: 614.835 matrículas ou 8,4\% do total.
} 
Gráfico 15 - Principais cursos com maior oferta de bolsas ProUni no processo seletivo 2/2013 (em \%)

Município de São Paulo-SP

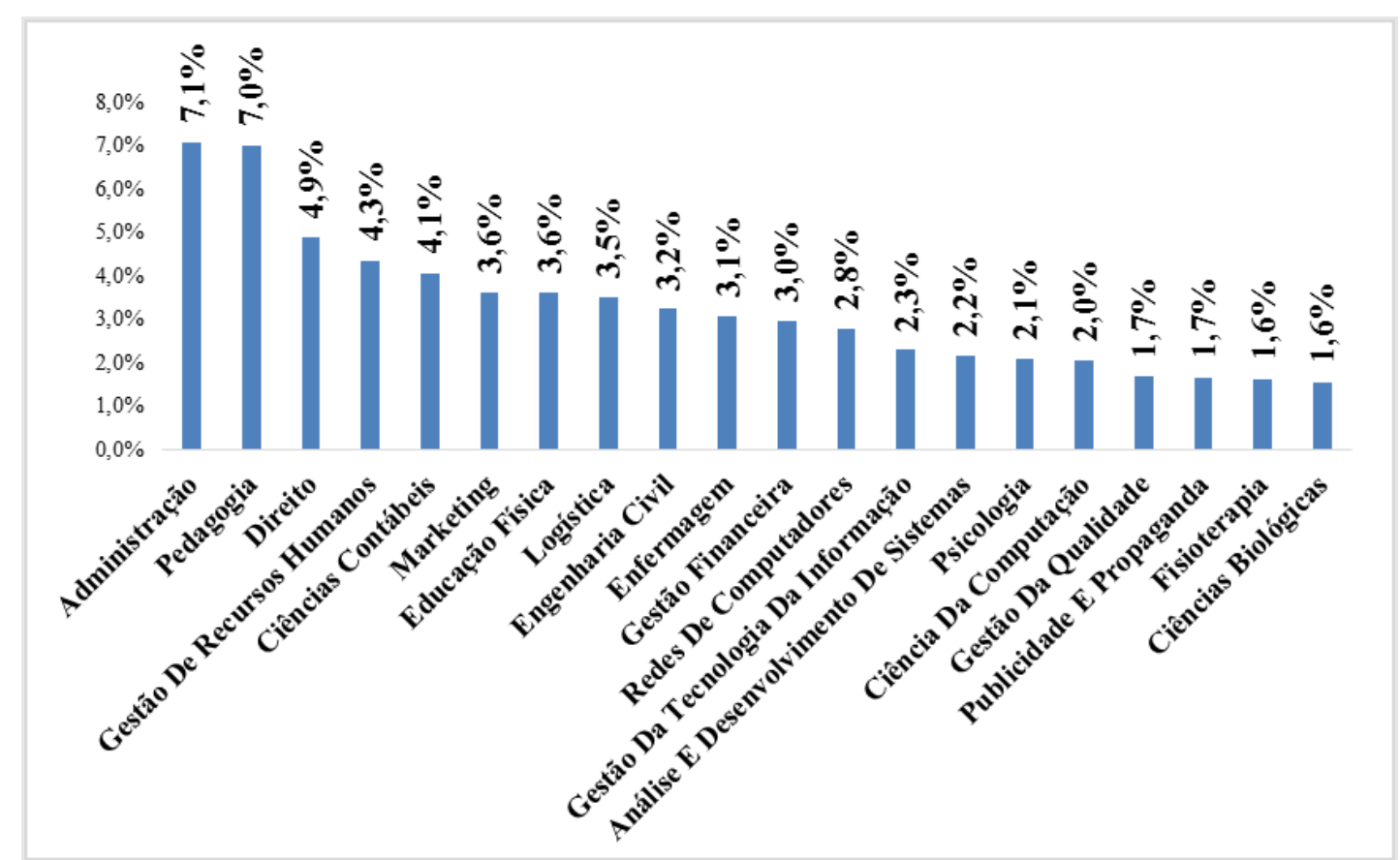

Fonte: E-SIC / Ministério da Educação.

Elaboração própria.

*Obs.: a soma dos 20 cursos não reflete o total ofertado no semestre.

Gráfico 16 - Principais cursos com maior oferta de bolsas ProUni no processo seletivo 1/2014 (em \%)

Município de São Paulo-SP

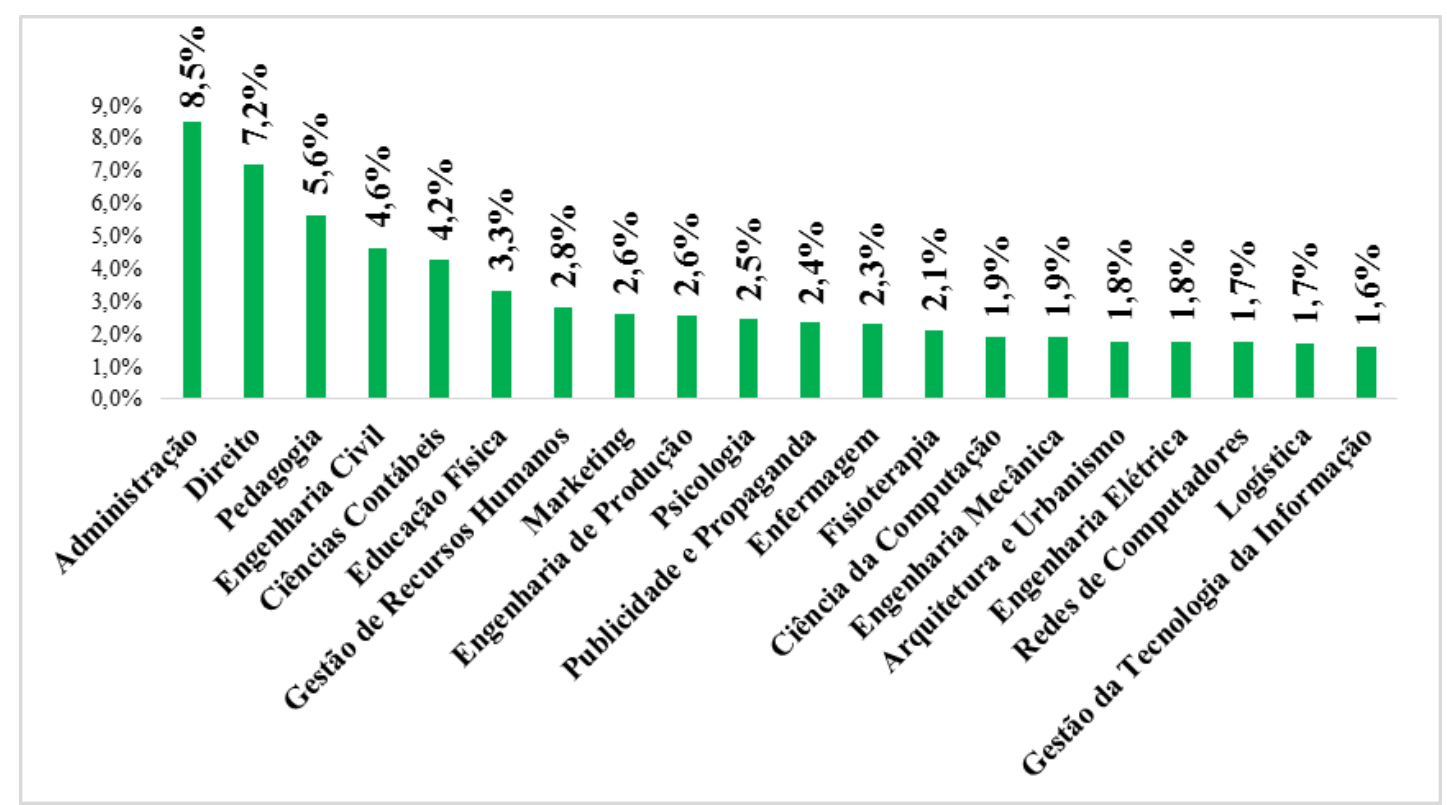

Fonte: E-SIC / Ministério da Educação.

Elaboração própria.

*Obs.: a soma dos 20 cursos não reflete o total ofertado no semestre. 
Nota-se maior participação dos Cursos Superiores de Tecnologia no segundo semestre de 2013, com 8 cursos (Gestão de Recursos Humanos, Marketing ${ }^{57}$, Logística, Gestão Financeira, Redes de Computadores, Gestão da Tecnologia da Informação, Análise e Desenvolvimento de Sistemas e Gestão da Qualidade, somando juntos 23,3\% do total ofertado no semestre). Já no primeiro semestre de 2014, os cursos de graduação de Bacharelado são maioria (15 de 20) entre os principais cursos com oferta de bolsas.

Foi observado que boa parte dos cursos apresentados entre os 20 primeiros a oferecer mais vagas, nos dois processos seletivos do ProUni, figuram na $\operatorname{lista}^{58}$ dos cursos mais concorridos do país, tais como: Engenharia Civil (e outras Engenharias), Direito, Psicologia, Publicidade e Propaganda e Arquitetura e Urbanismo. Por outro lado, os cursos de Licenciaturas, como Geografia, Matemática, História, Filosofia e outras, que possuem ingresso facilitado aos professores pela legislação do ProUni, não aparecem entre os 20 primeiros cursos.

Para efeito de comparação, vale a pena ressaltar sobre outros cursos que não aparecem na lista, mas que são prestigiados socialmente, com um alto custo das mensalidades e marcados pela acirrada concorrência nos principais vestibulares do país: Medicina, por exemplo, apresenta uma quantidade de bolsas reduzida (figurando na $72^{a}$ posição no primeiro semestre de 2014, com 53 bolsas).

Com os mesmos dados, porém visualizados em números absolutos e por tipo de bolsa (Tabela 12), é possível verificar que a maior parte das bolsas do processo seletivo 1/2014 para estes cursos é parcial. Juntos, os 20 primeiros cursos da lista representam 61,3\% do total de bolsas ofertadas para o primeiro semestre de 2014.

\footnotetext{
${ }^{57}$ Foi constatado durante o levantamento que o curso de Marketing possuía algumas opções de Bacharelado. Porém a oferta no modo de Cursos Superiores de Tecnologia era muito maior, portanto permaneceu enquadrado nesta categoria. Nota-se ainda que na nomenclatura oficial disponibilizada nos dados do MEC, não consta a diferenciação entre Bacharelados, Licenciaturas e Cursos Superiores de Tecnologia.

${ }^{58}$ Por exemplo, a lista da relação candidato/vaga do vestibular da Fundação Universitária para o Vestibular (FUVEST) de 2014, o mais concorrido do país.
} 
Tabela 12 - Principais cursos com maior oferta de bolsas ProUni no processo seletivo 1/2014, por tipo de bolsa

Município de São Paulo-SP

\begin{tabular}{lcccc}
\hline \multicolumn{1}{c}{ Curso } & $\begin{array}{c}\text { Bolsa } \\
\text { Parcial }\end{array}$ & $\begin{array}{c}\text { Bolsa } \\
\text { Integral }\end{array}$ & Total & $\begin{array}{c}\text { \% do total } \\
\text { ofertado* }\end{array}$ \\
\hline Administração & 1.435 & 850 & 2.285 & $\mathbf{8 , 5 \%}$ \\
Direito & 1.360 & 566 & 1.926 & $\mathbf{7 , 2 \%}$ \\
Pedagogia & 701 & 814 & 1.515 & $\mathbf{5 , 6 \%}$ \\
Engenharia Civil & 884 & 359 & 1.243 & $\mathbf{4 , 6 \%}$ \\
Ciências Contábeis & 770 & 370 & 1.140 & $\mathbf{4 , 2 \%}$ \\
Educação Física & 496 & 399 & 895 & $\mathbf{3 , 3 \%}$ \\
Gestão de Recursos Humanos & 381 & 377 & 758 & $\mathbf{2 , 8 \%}$ \\
Marketing & 390 & 313 & 703 & $\mathbf{2 , 6 \%}$ \\
Engenharia de Produção & 569 & 122 & 691 & $\mathbf{2 , 6 \%}$ \\
Psicologia & 475 & 183 & 658 & $\mathbf{2 , 5 \%}$ \\
Publicidade e Propaganda & 510 & 121 & 631 & $\mathbf{2 , 4 \%}$ \\
Enfermagem & 328 & 288 & 616 & $\mathbf{2 , 3 \%}$ \\
Fisioterapia & 373 & 198 & 571 & $\mathbf{2 , 1 \%}$ \\
Ciência da Computação & 369 & 137 & 506 & $\mathbf{1 , 9 \%}$ \\
Engenharia Mecânica & 365 & 140 & 505 & $\mathbf{1 , 9 \%}$ \\
Arquitetura e Urbanismo & 284 & 191 & 475 & $\mathbf{1 , 8 \%}$ \\
Engenharia Elétrica & 354 & 120 & 474 & $\mathbf{1 , 8 \%}$ \\
Redes de Computadores & 329 & 140 & 469 & $\mathbf{1 , 7 \%}$ \\
Logística & 199 & 256 & 455 & $\mathbf{1 , 7 \%}$ \\
Gestão da Tecnologia da Informação & 266 & 170 & 436 & $\mathbf{1 , 6 \%}$ \\
\hline
\end{tabular}

Fonte: E-SIC / Ministério da Educação.

Elaboração própria.

*Obs.: a soma dos 20 cursos não reflete o total ofertado no semestre.

Na Tabela 13, são visualizadas as 20 Instituições de Ensino Superior que mais ofertaram bolsas no processo seletivo do primeiro semestre de 2014, no município de São Paulo - SP. Destaca-se, novamente, que conforme visto na análise do estado de São Paulo, há uma grande concentração do total ofertado no semestre em grandes grupos universitários: Universidade São Judas Tadeu (USTJ), com 7.683 bolsas, ou 28,6\%; Universidade Nove de Julho (UNINOVE) com 10,8\% ou 2.886 bolsas; e Universidade Paulista (UNIP), com 10,1\% ou 2.720 bolsas. Somente estas três instituições juntas somam aproximadamente 50\% do total ofertado no semestre, indicando a pouca pulverização de instituições, e por consequência, podendo indicar a pouca diversificação do modelo de ensino ofertado no ProUni. As 20 primeiras instituições listadas representam $91 \%$ do total de bolsas oferecidas no semestre. 
Tabela 13 - Principais Instituições de Ensino Superior que mais ofertaram bolsas ProUni no processo seletivo $1 / 2014$

Município de São Paulo-SP

\begin{tabular}{lcc}
\hline \multicolumn{1}{c}{ Instituição de Ensino Superior } & $\begin{array}{c}\text { Número de } \\
\text { bolsas } \\
\text { ofertadas }\end{array}$ & $\begin{array}{c}\text { \% do total } \\
\text { ofertado no } \\
\text { semestre* }\end{array}$ \\
\hline Universidade São Judas Tadeu (USJT) & 7.683 & $\mathbf{2 8 , 6 \%}$ \\
Universidade Nove de Julho (UNINOVE) & 2.886 & $\mathbf{1 0 , 8 \%}$ \\
Universidade Paulista (UNIP) & 2.720 & $\mathbf{1 0 , 1 \%}$ \\
Universidade Ibirapuera (UNIB) & 1.830 & $\mathbf{6 , 8 \%}$ \\
Universidade Anhembi Morumbi (UAM) & 1.302 & $\mathbf{4 , 9 \%}$ \\
Faculdade São Paulo (FACSP) & 1.000 & $\mathbf{3 , 7 \%}$ \\
Centro Universitário das Faculdades Metropolitanas Unidas (FMU) & 980 & $\mathbf{3 , 7 \%}$ \\
Centro Universitário Anhanguera de São Paulo & 756 & $\mathbf{2 , 8 \%}$ \\
Universidade Cruzeiro do Sul (UNICSUL) & 749 & $\mathbf{2 , 8 \%}$ \\
Faculdade Sumaré (ISES) & 676 & $\mathbf{2 , 5 \%}$ \\
Faculdade de São Paulo (FATEMA) & 589 & $\mathbf{2 , 2 \%}$ \\
Faculdade Paulus de Tecnologia e Comunicação (FAPCOM) & 587 & $\mathbf{2 , 2 \%}$ \\
Universidade Cidade de São Paulo & 573 & $\mathbf{2 , 1 \%}$ \\
Pontifícia Universidade Católica de São Paulo (PUC-SP) & 396 & $\mathbf{1 , 5 \%}$ \\
Universidade de Santo Amaro (UNISA) & 381 & $\mathbf{1 , 4 \%}$ \\
Faculdade Centro Paulistano & 314 & $\mathbf{1 , 2 \%}$ \\
Centro Universitário Senac (SENACSP) & 305 & $\mathbf{1 , 1 \%}$ \\
Centro Universitário Estácio Radial de São Paulo - Estácio Uniradial & 241 & $\mathbf{0 , 9 \%}$ \\
Faculdade Flamingo & 227 & $\mathbf{0 , 8 \%}$ \\
Faculdade Paschoal Dantas (FPD) & 223 & $\mathbf{0 , 8 \%}$ \\
\hline Fote: E-SIC/Mis & &
\end{tabular}

Fonte: E-SIC / Ministério da Educação.

Elaboração própria.

*Obs.: a soma das 20 instituições não reflete o total ofertado no semestre.

Um ponto interessante a ser observado, justamente por sua ausência durante a análise dos dados, é que instituições de ensino tidas como "de elite", ou seja, possuidoras de grande prestígio social, caracterizadas como "especializadas em um determinado nicho acadêmico, direcionadas ao extrato de maior renda" (CARVALHO, 2013, p. 768), como por exemplo: a Escola Superior de Propaganda e Marketing (ESPM), a Fundação Getúlio Vargas (FGV) e o Instituto de Ensino e Pesquisa (INSPER), também localizadas no município de São Paulo - SP, não aparecem na lista de oferecimento de bolsas ProUni nos dois processos seletivos.

Desagregando ainda mais os dados, percebe-se que a concentração da oferta do ProUni em certas Instituições de Ensino Superior é ainda mais visível se observarmos por cursos. Para 
isso, foi selecionado o curso com o maior número de bolsas oferecidas no primeiro semestre de 2014, Administração (2.285 ou 8,5\% do total) e realizado o cruzamento com as 10 Instituições de Ensino que mais o ofertaram (Tabela 14). Verifica-se que a Universidade São Judas Tadeu (USTJ) aparece no primeiro lugar, concentrando sozinha um número de 874 bolsas, ou 38,2\% do total ofertado no semestre para o curso de Administração. Além disso, o quadro de concentração se repete no total das 10 instituições selecionadas: juntas, elas somam $81,8 \%$ do total da oferta de cursos de Administração no processo seletivo do primeiro semestre de 2014.

Tabela 14 - Principais Instituições de Ensino Superior que mais ofertaram bolsas ProUni do curso de Administração, no processo seletivo 1/2014

Município de São Paulo-SP

\begin{tabular}{lcc}
\hline \multicolumn{1}{c}{ Instituição de Ensino Superior } & $\begin{array}{c}\text { Número de bolsas } \\
\text { ofertadas }\end{array}$ & $\begin{array}{c}\text { \% do total } \\
\text { ofertado no } \\
\text { semestre* }\end{array}$ \\
\hline Universidade São Judas Tadeu (USJT) & 874 & $\mathbf{3 8 , 2 \%}$ \\
Universidade Paulista (UNIP) & 201 & $\mathbf{8 , 8 \%}$ \\
Faculdade São Paulo (FACSP) & 200 & $\mathbf{8 , 8 \%}$ \\
Universidade Nove de Julho (UNINOVE) & 149 & $\mathbf{6 , 5 \%}$ \\
Centro Universitário Anhanguera de São Paulo & 119 & $\mathbf{5 , 2 \%}$ \\
Universidade Anhembi Morumbi (UAM) & 83 & $\mathbf{3 , 6 \%}$ \\
Universidade Cruzeiro do Sul (UNICSUL) & 69 & $\mathbf{3 , 0 \%}$ \\
Faculdade Centro Paulistano & 67 & $\mathbf{2 , 9 \%}$ \\
Pontifícia Universidade Católica de São Paulo (PUC-SP) & 65 & $\mathbf{2 , 8 \%}$ \\
Faculdade Carlos Drummond de Andrade (FCDA) & 49 & $\mathbf{2 , 1 \%}$ \\
\hline Fonte: E-SIC / Ministério da Educação. & & \\
Elaboração própria. & & \\
*Obs.: a soma das 10 instituições não reflete o total ofertado no semestre. &
\end{tabular}

Em síntese, neste Capítulo foram discutidos alguns dos aspectos sobre o Programa Universidade para Todos, a partir dos debates realizados na literatura e também da análise de dados sobre a abrangência dessa política, que contemplaram o número de bolsas, perfil dos bolsistas, regiões geográficas, IES e cursos que ofereceram bolsas, entre outros temas.

Os dados desagregados sobre o ProUni, que são informações novas, suscitaram algumas questões interessantes, como por exemplo: a alta concentração do oferecimento de bolsas em poucas IES participantes do Programa, muitas vezes pertencentes a grandes grupos educacionais; em relação às regiões geográficas, a oferta se dá predominantemente no Sudeste; e em relação aos cursos ofertados, as bolsas estão visivelmente concentradas na área de Ciências 
Humanas (Administração, Direito e Pedagogia), ou seja, uma área caracterizada pelo baixo investimento. Conforme explicitado neste Capítulo, esse quadro reflete um patamar muito semelhante ao identificado no sistema de educação superior brasileiro em geral.

Considerando os diversos questionamentos suscitados tanto pela exploração dos dados, quanto pelas lacunas identificadas na literatura, nesta pesquisa foi realizada a escolha de investigar os cursos que participam do ProUni, um campo ainda pouco explorado nos trabalhos sobre o tema. Conforme disposto na bibliografia, diversas problematizações foram geradas sobre os cursos que participam do ProUni, especialmente no que tange à qualidade e avaliação dos mesmos. Perguntas como: quais são os cursos ofertados? Quais Instituições de Ensino Superior os ofertam? Estes cursos e instituições possuem qualidade (e sobre qual noção de qualidade está se discutindo?), ainda permeiam as discussões sobre o ProUni. Verifica-se, ainda, a ausência de pesquisas concluídas que discutam mais profundamente sobre os processos de avaliação e controle dos cursos e IES que fazem parte do Programa.

A possibilidade de análise especificamente sobre esses cursos, cujos dados contemplam as áreas de conhecimento, as Instituições de Ensino Superior que os oferecem, turnos, modalidades de ensino, recortes por Unidade da Federação, por município, por processos seletivos, etc., permitiu dar prosseguimento à pesquisa nesse sentido, o que será realizado no próximo Capítulo. 


\section{CAPÍTULO 3 - A QUALIDADE NO PROGRAMA UNIVERSIDADE PARA TODOS (PROUNI) SEgUNDO OS RESUltados DE AVALIAÇÃo do CONCEITO PRELIMINAR DE CURSO (CPC).}

O objetivo deste Capítulo é reunir informações disponíveis para subsidiar a discussão sobre a qualidade nos cursos que ofertam bolsas no Programa Universidade para Todos. Para tanto, os cursos do ProUni foram relacionados aos resultados de avaliação no âmbito do SINAES, mais precisamente do Conceito Preliminar de Curso (CPC).

É realizada, primeiramente, uma revisão bibliográfica acerca dos principais aspectos que norteiam a construção e aplicação do Conceito Preliminar de Curso: os debates em torno de sua criação, os aspectos metodológicos da construção do indicador e sua operacionalização.

Em seguida, problematiza-se sobre como é realizado o processo de avaliação dos cursos que ofertam bolsas pelo ProUni, bem como quais são os critérios atualmente empregados, resgatando a legislação e os instrumentos referentes ao assunto.

Por fim, a última seção traz a metodologia e a análise referente ao cruzamento dos dados do CPC em relação aos dos cursos que ofereceram bolsas do ProUni, levantando as possíveis problemáticas a este respeito, à luz do debate teórico e do levantamento bibliográfico deste e dos capítulos anteriores.

\subsection{A Avaliação de cursos no SINAES: o Conceito Preliminar de Curso (CPC)}

O Conceito Preliminar de Curso (CPC) é considerado o Indicador de Qualidade da Educação Superior voltado aos cursos superiores de graduação, no âmbito do Sistema Nacional de Avaliação da Educação Superior brasileira, o SINAES (BRASIL, 2010a).

Na lei do SINAES ( ${ }^{\circ}$ 10.861/2004), foram previstos diferentes parâmetros para o processo de avaliação dos cursos superiores, em especial três dimensões: corpo docente, instalações físicas e organização didático-pedagógica:

Art. $4^{\circ} \mathrm{A}$ avaliação dos cursos de graduação tem por objetivo identificar as condições de ensino oferecidas aos estudantes, em especial as relativas ao perfil do corpo docente, às instalações físicas e à organização didáticopedagógica.

$\S 1^{\circ}$ A avaliação dos cursos de graduação utilizará procedimentos e instrumentos diversificados, dentre os quais obrigatoriamente as visitas por comissões de especialistas das respectivas áreas do conhecimento. 
$\S 2^{\circ}$ A avaliação dos cursos de graduação resultará na atribuição de conceitos, ordenados em uma escala com 5 (cinco) níveis, a cada uma das dimensões e ao conjunto das dimensões avaliadas. (BRASIL, 2004b).

O Conceito foi anunciado pela primeira vez (BARREYRO e ROTHEN, 2014; BRASIL, 2014a) na versão original da Portaria Normativa MEC n 40/2007, em que foi indicada, para a efetivação dos processos inerentes ao calendário avaliativo do SINAES, a atribuição de

[...] um conceito preliminar, gerado a partir de informações lançadas por instituições ou cursos no Censo da Educação Superior, nos resultados do Exame Nacional de Desempenho de Estudantes (ENADE) e nos cadastros próprios do INEP [...] (BRASIL, 2007a, Art. 35, § 1º)

Nesse movimento, visando consolidar as disposições da lei do SINAES e da Portaria Normativa $\mathrm{n}^{\circ} 40$, a aplicação do conceito preliminar, posteriormente denominado de Conceito Preliminar de Curso, foi regulamentada em agosto de 2008 pela Portaria Normativa MEC $\mathrm{n}^{\circ} 4$, que versa sobre a aplicação do conceito preliminar para fins dos processos de renovação de reconhecimento de cursos superiores. Segundo a Portaria, o INEP se tornou responsável pela divulgação dos conceitos preliminares de cada curso, anualmente, considerando as áreas avaliadas pelo SINAES. Assim como as demais avaliações relativas ao SINAES, a atribuição da nota final deve ser em uma escala em cinco níveis (1 a 5). Conforme a Portaria Normativa $\mathrm{n}^{\circ} 4$, "considera-se conceito preliminar satisfatório o igual ou superior a três" (BRASIL, 2008a, Art. $2^{\circ}, \S 1^{\circ}$ ), e "insatisfatório o conceito preliminar inferior a três" (BRASIL, 2008a, Art. $3^{\circ}, \S$ $\left.1^{\circ}\right)$.

Com a republicação, em 2010, da Portaria Normativa $n^{\circ} 40 / 2007$, o CPC foi considerado, oficialmente (BRASIL, 2014a), como o Indicador de Qualidade da Educação Superior voltado aos cursos de graduação, no âmbito do SINAES:

São indicadores de qualidade, calculados pelo Inep, com base nos resultados do Enade e demais insumos constantes das bases de dados do MEC, segundo metodologia própria, aprovada pela CONAES, atendidos os parâmetros da Lei $\mathrm{n}^{\mathrm{o}} 10.861$, de 2004:

I - de cursos superiores: o Conceito Preliminar de Curso (CPC), instituído pela Portaria Normativa $n^{\circ}$ 4, de 05 de agosto de 2008; [...]

Os indicadores de qualidade são expressos em escala contínua e numa escala de cinco níveis, em que os níveis iguais ou superiores a 3 (três) indicam qualidade satisfatória. Eles servem como orientadores das avaliações in loco do ciclo avaliativo, sendo importantes instrumentos de avaliação da educação superior brasileira (BRASIL, 2010a, Art. 33-B, grifo meu). 
Um dos objetivos previstos no SINAES, para a avaliação de cursos, são as visitas presenciais realizadas por comissões de especialistas das respectivas áreas do conhecimento. Por possuir um caráter preliminar, como o próprio nome sugere, a intenção é que o CPC possa subsidiar esses processos de avaliação in loco realizadas por esses especialistas ${ }^{59}$ nas instituições de ensino (BRASIL, 2013a). Neste processo, pelo fato de o CPC estar baseado nos resultados do ENADE, entende-se que a "supervisão do sistema centrou-se na utilização de resultados do ENADE como balizadores para a realização de visitas in loco por especialistas" (BARREYRO e ROTHEN, 2014, p. 69).

Além disso, o CPC obtido pelo curso, se considerado satisfatório - ou seja, igual ou superior a três - pode resultar na dispensa da visita presencial: "os cursos que tenham obtido conceito preliminar satisfatório ficam dispensados de avaliação in loco nos processos de renovação de reconhecimento respectivos" (BRASIL, 2008a, Art. $2^{\circ}$ ). Nestes casos, se o CPC for três ou quatro, é facultativo à instituição de ensino o requerimento ${ }^{60}$ de visita presencial, caso queiram modificar ou confirmar o CPC atribuído previamente. Se a instituição não requisitar a visita, o CPC torna-se definitivo.

Por outro lado, se a nota final obtida do CPC for inferior a três (considerada insatisfatória), o curso, obrigatoriamente, deve se submeter à avaliação presencial da comissão de especialistas. Quando ocorre essa modalidade de avaliação, o CPC pode ser confirmado ou alterado, tornando-se automaticamente o Conceito de Curso (CC), que possui caráter definitivo. Os cursos que obtiverem CPC insatisfatório e não seguirem o trâmite da avaliação presencial serão considerados em situação irregular (BRASIL, 2008a, Art. $3^{\circ}, \S 5^{\circ}$ ).

A questão da necessidade de avaliação por meio de visitas presenciais, prevista no SINAES desde 2004, tornou-se um dilema para todo o processo de avaliação da educação superior, se considerada a grande expansão ${ }^{61}$ ocorrida do segmento no Brasil, que segundo os Censos da Educação Superior (INEP), contava, em 1996, com 922 instituições de ensino superior e 6.644 cursos de graduação (presencial e a distância), expandindo-se, em 2013, para 2.391 instituições (variação de 159\%) e 32.049 cursos (variação de 382\%). Segundo a visão do INEP em publicação técnica,

\footnotetext{
59 Avaliadores inscritos no Banco de Avaliadores do Sistema Nacional de Avaliação da Educação Superior (BASis).

${ }^{60}$ Segundo a Portaria Normativa MEC n $4 / 2008$, o processo de renovação de reconhecimento para os cursos que obtiverem CPC 5 será encaminhado por meio de expedição de portaria.

${ }^{61}$ Para maiores detalhes sobre o processo de expansão da educação superior, ver o Capítulo 1 - Educação Superior, Avaliação e Qualidade.
} 
[...] ao dispensar da visita os cursos com indicador 3, 4 e 5, o CPC viabiliza as avaliações in loco e, por servir de guia para os avaliadores, induz uma maior coerência entre essas avaliações e os indicadores objetivos de qualidade (FERNANDES et al., 2009, p. 6).

Entretanto, as consequências da dispensa da visita presencial podem ser observadas por outra perspectiva. Segundo Rothen e Barreyro (2011), citando informações do Portal MEC divulgadas em 2008, por meio do CPC seria possível reduzir o número de 3.000 visitas previstas por ano, para 1.800. Para os autores, com a medida, o MEC “parece visar diminuir o número de cursos a receberem avaliação externa in loco e, assim, aligeirar o processo de reconhecimento de cursos, perdendo espaço a avaliação formativa e o rigor regulatório" (ROTHEN e BARREYRO, 2011, p. 31). Ainda, os autores reforçam que a visita da comissão de especialistas, a qual operacionaliza a avaliação presencial de cursos, é obrigatória na lei do SINAES; entretanto, é dispensada na Portaria Normativa que regulamentou a aplicação do CPC: "assim, a lei do SINAES sancionada no primeiro Governo Lula foi desrespeitada por ato normativo de menor hierarquia jurídica: uma portaria" (BARREYRO e ROTHEN, 2014, p. 69).

De fato, segundo o INEP (BRASIL, 2014a, p. 5), os indicadores de qualidade da educação superior (CPC, IGC e Conceito ENADE ${ }^{62}$ ) "têm se constituído em importantes medidas" para as ações da Secretaria de Regulação da Educação Superior (SERES), situação em que se verifica que essa Secretaria “tem publicado diversas Instruções Normativas aplicando medidas regulatórias (como a abertura de Protocolos de Compromisso e suspensão da entrada de estudantes) para cursos e IES apenas com base no CPC e IGC” (BRASIL, 2014a, p. 5).

Com relação à composição e operacionalização do CPC, este é calculado sempre ao ano seguinte da realização do Exame Nacional de Desempenho dos Estudantes (ENADE) de cada área. É divulgado anualmente para os cursos que possuíram pelo menos dois estudantes concluintes participantes e dois estudantes ingressantes registrados no Sistema ENADE. O indicador é composto de informações, já existentes, sobre as Instituições de Ensino Superior que ofertam os cursos, por meio de elementos como: infraestrutura, recursos didáticopedagógicos, corpo docente e desempenho dos estudantes.

A primeira Nota Técnica formalizando as diretrizes para a aplicação do Conceito Preliminar de Curso na avaliação dos cursos superiores foi divulgada em 2008, pela Diretoria de Avaliação da Educação Superior (DAES) do INEP, referente aos indicadores calculados, pela primeira vez, em 2007 (BRASIL, 2014a).

\footnotetext{
62 Índice Geral de Cursos (IGC), utilizado para avaliar as Instituições de Ensino Superior, e Conceito ENADE, para avaliar o desempenho dos estudantes. Para mais detalhes, consultar o Capítulo 1, na seção sobre o SINAES.
} 
O CPC é calculado anualmente, somente para alguns cursos superiores, pois toma como base os mesmos cursos escolhidos para a avaliação do ENADE - até mesmo por depender diretamente de seus resultados para a composição do Conceito, conforme será observado posteriormente. A escolha dos cursos que serão avaliados pelo ENADE em determinado ano é realizada pela Comissão Nacional de Avaliação da Educação Superior $\left(\operatorname{CONAES}^{63}\right)$, observado o calendário de avaliação, em que o ENADE é aplicado aos estudantes de cada área a cada três $\operatorname{anos}^{64}$. Para exemplificar a questão, no ano de 2012, foram avaliadas as áreas de Ciências sociais aplicadas, Ciências humanas e áreas afins, Gestão e negócios, Apoio escolar, Hospitalidade e lazer, Produção cultural e Design. Os cursos de graduação, seguindo esse critério, foram: Administração, Direito, Ciências Econômicas, Psicologia, Ciências Contábeis, Design, Turismo, Secretariado Executivo, Relações Internacionais, Tecnologia em Marketing, Tecnologia em Processos Gerenciais, Tecnologia em Recursos Humanos, Tecnologia em Gestão Financeira, Tecnologia em Gestão Comercial, Tecnologia em Logística, Jornalismo e Publicidade e Propaganda.

É necessário ressaltar que, no caso do CPC, assim como para o Conceito ENADE, o cálculo do indicador é realizado por Unidade de Observação, e não necessariamente por curso. Segundo a Nota Metodológica dos Indicadores de Qualidade da Educação Superior 2012 do INEP,

[...] o cálculo do Conceito Enade e do Conceito Preliminar de Curso (CPC) não é necessariamente realizado para o Curso, mas para a Unidade de Observação (Unidade)i, que consiste no conjunto de cursos que compõe uma área de avaliação específica do Enade de uma Instituição de Educação Superior em um determinado município (BRASIL, 2013a, p. 9, grifo no original).

O cálculo do CPC, segundo a mesma Nota Metodológica, é obtido pela agregação das seguintes variáveis: desempenho médio de estudantes nas avaliações do ENADE; respostas ao Questionário do Estudante (que compõe o ENADE); avaliação do corpo docente; infraestrutura; recursos didático-pedagógicos e demais insumos. Ainda, o "propósito do CPC é agrupar diferentes medidas da qualidade do curso, entendidas como medidas imperfeitas da

\footnotetext{
${ }^{63}$ A Comissão Nacional de Avaliação da Educação Superior (CONAES) é um órgão que coordena e supervisiona o SINAES, em que algumas de suas atribuições são: propor e avaliar as dinâmicas, procedimentos e mecanismos da avaliação institucional, de cursos e de desempenho dos estudantes.

${ }^{64}$ Cada área de enquadramento é avaliada trienalmente no ENADE, conforme disposto na Portaria MEC $\mathrm{n}^{\circ}$ 40/2010, Art. 33-E. A descrição das áreas avaliadas anualmente encontra-se no Anexo A deste trabalho.
} 
contribuição do curso para a formação dos estudantes, em uma única medida com menor erro" (BRASIL, 2013a, p. 14).

No caso do CPC do ano de 2012, indicador escolhido para compor a análise de dados neste trabalho, foram contemplados ao todo sete componentes para o cálculo da nota final, conforme orientação técnica aprovada na CONAES (BRASIL, 2013a). A seguir, estão listados os componentes, bem como as fontes das respectivas informações, que serão detalhadas mais adiante:

- Desempenho médio dos concluintes nas provas de Formação Geral e Componente Específico: ENADE 2012;

- Respostas dos estudantes sobre as questões referentes à infraestrutura e organização didático-pedagógica: Questionário do Estudante do ENADE 2012;

- Respostas dos estudantes ingressantes sobre a escolaridade dos pais: Questionário Socioeconômico do Exame Nacional do Ensino Médio (ENEM) de 2010 ou 2011;

- Resultados do Indicador de Diferença entre os Desempenhos Observado e Esperado (IDD): composto por variáveis do Enem, ENADE e Questionários do Estudante do ENEM e ENADE;

- Informações sobre o corpo docente, como o número total (número de funções docentes), com titulação de mestrado e de doutorado, e tipo de regime de trabalho (parcial ou integral): Censo da Educação Superior 2012.

Com relação às informações do corpo docente, que são extraídas por meio do cadastro das Instituições no módulo de docentes do Censo da Educação Superior, vinculando-os a cada curso em que lecionam, o cálculo do número de professores mestres envolve o número total de docentes vinculados à Unidadei ${ }^{65}$ cuja titulação seja maior ou igual ao Mestrado e o número total de docentes desta Unidade. Se não houver nenhum docente com Mestrado na Unidade, a nota da proporção de mestres será 0 (zero).

A mesma situação ocorre no caso do cálculo do número de professores doutores, que envolve o número total de docentes vinculados à Unidadei cuja titulação seja maior ou igual ao Doutorado e o número total de docentes desta Unidade. A informação é também extraída do

\footnotetext{
${ }^{65}$ O INEP utiliza, em seus documentos oficiais, o termo "Unidadei” para se referir a "unidade de observação".
} 
cadastro do Censo da Educação Superior. Se não houver nenhum docente com Doutorado na Unidade, a nota de proporção de doutores será 0 (zero).

Para a nota dos professores com relação ao regime de dedicação de trabalho (parcial ou integral), o cálculo consiste no número total de docentes vinculados à Unidadei cujo regime de dedicação seja integral ou parcial e o número total de docentes desta Unidade. De forma semelhante aos outros insumos, a Unidade que não possuir nenhum docente nos regimes descritos, também terá a nota computada como 0 (zero).

Para a nota relativa à Infraestrutura, são utilizados o número total de estudantes vinculados à Unidadei que responderam sobre a questão relativa à infraestrutura no Questionário do Estudante do $\mathrm{ENADE}^{66}$, em que são gerados pesos diferentes para cada resposta, no cálculo da nota de infraestrutura do CPC (BRASIL, 2013a). Quando nenhum estudante respondeu esta questão, a nota da Unidade será 0 (zero).

Para a nota relativa à Organização Didático-Pedagógica, são utilizados o número total de estudantes vinculados à Unidadei que responderam sobre a questão ${ }^{67}$ relativa ao tema no Questionário do Estudante no ENADE, em que também são atribuídos pesos diferentes para cada resposta, no cálculo da nota final de infraestrutura do CPC (BRASIL, 2013a). Quando nenhum estudante respondeu esta questão, a nota da Unidade será 0 (zero).

A nota dos Concluintes do ENADE refere-se à mesma nota que dá origem ao Conceito ENADE: "para cada Unidadei considera-se $75 \%$ da nota dos estudantes concluintes no componente específico do Enade e $25 \%$ da nota dos mesmos estudantes no componente de formação geral do Enade" (BRASIL, 2013a, p. 18).

A nota atribuída em relação ao Indicador de Diferença entre os Desempenhos Observado e Esperado (IDD), que é um indicador criado no âmbito do SINAES, segundo os documentos oficiais (BRASIL, 2013a) visa mensurar as diferenças em relação ao perfil dos estudantes ao ingressar e ao concluir o ensino superior, o que não é explicado somente pelas diferenças de qualidade entre os cursos. De acordo com Bittencourt et al. (2008, p. 254), o IDD surge "motivado pelo fato de que o perfil dos ingressantes varia entre os cursos e entre as IES,

\footnotetext{
${ }^{66}$ Pergunta: "Os equipamentos e/ou materiais disponíveis nos ambientes para aulas práticas são suficientes para o número de estudantes? (Se for estudante de EaD - Educação a Distância, considere as condições do polo de apoio presencial e/ou sede)". As possíveis respostas são: “A) Sim, todos; B) Sim, a maior parte; C) Somente alguns; D) Nenhum".

${ }^{67}$ Pergunta: "Na maioria das vezes, os planos de ensino apresentados pelos professores contêm os seguintes aspectos: objetivos, metodologias de ensino e critérios de avaliação, conteúdos e bibliografia da disciplina?". As possíveis respostas são: “A) Sim, todos os aspectos; B) Sim, a maior parte dos aspectos; C) Somente alguns aspectos; D) Nenhum dos aspectos; E) Não sei responder”.
} 
fazendo com que as notas dos concluintes tendam a refletir essas desigualdades". Segundo o INEP,

O Indicador de Diferença entre os Desempenhos Observado e Esperado (IDD) tem o propósito de trazer às Instituições informações comparativas dos desempenhos de seus estudantes concluintes em relação aos resultados médios obtidos pelos concluintes das demais Instituições que possuem estudantes ingressantes de perfil semelhante ao seu. Para tanto, o IDD, como o próprio nome já diz, é resultante da diferença entre o desempenho médio obtido no Enade pelos estudantes concluintes de um curso e o desempenho médio que era esperado para esses mesmos estudantes, dadas as informações existentes sobre o perfil dos ingressantes desse curso (BRASIL, 2013a, p. 18).

Nesse sentido, o IDD utiliza diferentes variáveis (desempenho de ingressantes e de concluintes, nível de escolaridade dos pais dos ingressantes, razão entre o número de concluintes e ingressantes, entre outras ${ }^{68}$ ) (BITTENCOURT et al., 2008) para calcular a diferença entre a nota obtida pelos concluintes e a nota que seria esperada com relação aos ingressantes, de acordo com o perfil de um mesmo curso.

Quando não for possível atribuir a nota do IDD para uma Unidadei (por não ser possível a estimativa de alguns parâmetros necessários ao cálculo), foi estabelecido que a nota do IDD receberá o mesmo valor da nota de Concluintes para o cálculo do CPC.

Para realizar a padronização das notas de todos os componentes do CPC, para que sigam uma escala de 0 a 5, é adotado o recurso estatístico de "afastamento padronizado" (BRASIL, 2013a, p. 10), em que se utilizam as médias e os desvios-padrões calculados por área de avaliação. Com isso, é realizada uma aproximação da nota dos componentes em relação à média nacional obtida pela área de avaliação:

[...] esta padronização é feita da seguinte forma: toma-se a medida original para cada Unidade i (por exemplo, a proporção de professores mestres dessa Unidade) e subtrai-se dela a média dessa medida obtida para a área de avaliação em nível nacional $\mathbf{J}$ a qual esta Unidade pertence. Divide-se o resultado da subtração pelo desvio padrão da medida obtido para a área de avaliação em nível nacional J a qual esta Unidade pertence (BRASIL, 2013a, p. 10)

\footnotetext{
${ }^{68}$ Mais informações sobre o cálculo do Indicador de Diferença entre os Desempenhos Observado e Esperado
} (IDD) podem ser encontradas no Anexo C deste trabalho. 
Posteriormente, os resultados dos afastamentos padronizados são transformados em notas padronizadas (processo de interpolação linear) para cada componente, que também podem variar de 0 a 5 .

Utilizando como base todos os componentes descritos e padronizados, a forma de cálculo da nota final do Conceito Preliminar de Curso (também na escala de 0 a 5) é obtida por meio de uma ponderação ${ }^{69}$ das notas de cada componente, em que cada uma possui um peso diferente no resultado da nota final, conforme ilustram a equação da Figura 1 e a Tabela 15:

Figura 1 - Equação de cálculo do Conceito Preliminar de Curso 2012.

$$
\begin{aligned}
& C P C_{i}=\left(0,35 \times N I D D_{i}\right)+\left(0,20 \times N C_{i}\right)+ \\
& \left(0,15 \times N P D_{i}\right)+\left(0,075 \times N P M_{i}\right)+\left(0,075 \times N P R_{i}\right)+\left(0,075 \times N F_{i}\right)+\left(0,075 \times N O_{i}\right)
\end{aligned}
$$

Fonte: BRASIL, 2013a

Tabela 15 - Peso dos Componentes no Conceito Preliminar de Curso 2012.

\begin{tabular}{c|c|c|c}
\hline \multirow{2}{*}{ Componentes do CPC } & \multicolumn{2}{c}{ Peso na nota final } \\
\hline \multirow{2}{*}{$\begin{array}{c}\text { Desempenho dos } \\
\text { Estudantes }\end{array}$} & $\mathrm{NC}$ & \multirow{2}{*}{$55 \%$} & $20 \%$ \\
\cline { 2 - 2 } $\begin{array}{c}\text { Questionário do } \\
\text { Estudante }- \\
\text { ENADE }\end{array}$ & $\mathrm{NIDD}$ & $\mathrm{NF}$ & $35 \%$ \\
\cline { 2 - 2 } & $\mathrm{NO}$ & $15 \%$ & $7,5 \%$ \\
\hline \multirow{2}{*}{\begin{tabular}{c} 
Corpo Docente \\
\cline { 2 - 2 }
\end{tabular}} & $\mathrm{NPD}$ & $\mathrm{NPM}$ & $7,5 \%$ \\
\cline { 2 - 2 } & $\mathrm{NPR}$ & $30 \%$ & $75 \%$ \\
\cline { 2 - 2 } & & $7,5 \%$ \\
\hline
\end{tabular}

Fonte: BRASIL, 2013a

Elaboração própria.

Portanto, pode-se dizer que o CPC é uma média ponderada de diversas medidas, previamente estabelecidas, relativas à qualidade de um curso. Realizando a leitura dos valores da equação em números percentuais (Tabela 15), observa-se que 35\% do peso é atribuído à

\footnotetext{
${ }^{69}$ Para estabelecer essa ponderação, foram elaborados estudos pela equipe técnica do INEP, apresentados na Nota Técnica MEC/INEP/DAES n ${ }^{\circ}$ 29/2012, bem como foram realizadas “discussões com a Secretaria de Regulação e Supervisão da Educação Superior - SERES/MEC, Conaes e representantes de IES públicas e privadas interessadas" (BRASIL, 2013a, p. 18). Vale ressaltar que as variáveis, o peso e o cálculo sofreram modificações metodológicas em algumas edições do CPC.
} 
Nota do Indicador de Diferença entre os Desempenhos Observado e Esperado (NIDD); outros $20 \%$, em relação à Nota dos Concluintes (NC), resultando em um total de 55\% atribuído ao desempenho dos estudantes. A Nota de Infraestrutura (NF) possui peso de 7,5\%, assim como a Nota de Organização Didático-Pedagógica (NO), que juntas somam 15\% atribuído ao quesito obtido por meio das respostas dos estudantes ao Questionário do Estudante do ENADE. Com relação ao corpo docente, é atribuído um peso de 30\%, distribuído em $15 \%$ para a Nota de Professores Doutores (NPD), 7,5\% para a Nota de Professores Mestres (NPM) e 7,5\% para a Nota sobre Regime de Trabalho parcial/integral (NPR).

Com isso, o resultado é o Conceito Preliminar de Curso (CPCi) em valores contínuos, que posteriormente são arredondados para cima e apresentados por faixas (também de 1 a 5):

Tabela 16 - Valores contínuos e valores por faixas do Conceito Preliminar de Curso 2012.

\begin{tabular}{c|c}
\hline CPC - Valor Contínuo & CPC - Faixa \\
\hline $0 \leq \mathrm{CPCi}<0,945$ & 1 \\
\hline $0,945 \leq \mathrm{CPCi}<1,945$ & 2 \\
\hline $1,945 \leq \mathrm{CPCi}<2,945$ & 3 \\
\hline $2,945 \leq \mathrm{CPCi}<3,945$ & 4 \\
\hline $3,945 \leq \mathrm{CPCi} \leq 5$ & 5 \\
\hline
\end{tabular}

Fonte: BRASIL, 2013a

Nota: Os cursos com CPC contínuo maior ou igual a 3,95 somente poderão obter o valor máximo do indicador (faixa igual a 5), caso tenham obtido nota maior que 0,95 em todos os componentes.

Vale ressaltar que algumas unidades de observação ficam classificadas como Sem Conceito (SC), pois não possuíram os requisitos mínimos dos critérios estabelecidos para obter o CPC, ou seja, dois ingressantes inscritos e dois concluintes participantes do ENADE (BRASIL, 2013a). Ainda, há casos que as unidades são classificadas como unidade com cursos não reconhecidos.

Entretanto, a metodologia empregada no cálculo do CPC sofreu algumas modificações desde o seu surgimento (2007), tanto em relação aos componentes que o integram, quanto em relação aos pesos de cada insumo para a composição da nota final. A ponderação das diferentes variáveis para o cálculo do CPC é definida a partir de estudos da equipe técnica do INEP e discussões na CONAES para orientação e aprovação (BRASIL, 2009c, 2014a). 
O Quadro 2 exibe um panorama acerca das principais mudanças metodológicas ocorridas no indicador desde a sua criação, as quais serão detalhadas logo após:

Quadro 2 - Principais aspectos e mudanças do cálculo do Conceito Preliminar de Curso (CPC) no período de 2007 a 2013.

\begin{tabular}{c|l}
\hline Anos & \multicolumn{1}{c}{ Descrição } \\
\hline $\mathbf{2 0 0 7}$ & $\begin{array}{l}\text { 3 componentes: (1) nota padronizada contínua do ENADE (nota_Enade), (2) nota } \\
\text { padroniza contínua do IDD (nota_IDD) e (3) nota padronizada contínua dos insumos que } \\
\text { retratam a qualidade do curso (nota_Insumos), e subcomponentes. }\end{array}$ \\
\hline $\mathbf{2 0 0 8}$ & $\begin{array}{l}\text { 8 componentes: - 1 - Nota dos Concluintes no ENADE (NC); 2 - Nota dos Ingressantes no } \\
\text { ENADE (NI); 3 - Nota do Indicador de Diferença entre os Desempenhos Observado e } \\
\text { Esperado (NIDD); 4 - Nota de Professores Doutores (NPD); 5 - Nota de Professores } \\
\text { Mestres (NPM); 6 - Nota de Professores com Regime de Dedicação Integral ou Parcial } \\
\text { (NPR); 7 - Nota de Infraestrutura (NF); e 8 - Nota referente à Organização Didático- } \\
\text { Pedagógica (NO). }\end{array}$ \\
\hline $\mathbf{2 0 1 1}$ & $\begin{array}{l}\text { 7 componentes. Retirada a Nota dos Ingressantes no ENADE (NI) do cálculo, passando a } \\
\text { utilizar o resultado do desempenho dos estudantes do ENEM no cálculo do IDD; } \\
\text { redistribuição dos pesos dos componentes do CPC. }\end{array}$ \\
\hline $\mathbf{2 0 1 3}$ & $\begin{array}{l}\text { Alteração na utilização dos insumos do Questionário do Estudante do ENADE no cálculo } \\
\text { do CPC, ampliando os itens sobre percepção discente sobre as condições do processo } \\
\text { formativo. }\end{array}$ \\
\hline
\end{tabular}

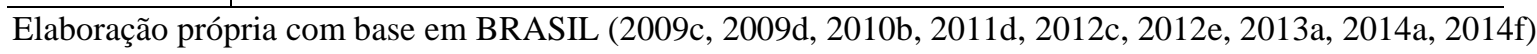

Conforme observado no Quadro 2, a primeira revisão do CPC se deu em 2008 (BRASIL, 2014a), por meio da reorganização dos componentes do cálculo (explicitação dos subcomponentes na fórmula, que antes, era reduzida a 3 componentes que continham alguns subcomponentes; após a mudança metodológica, a fórmula passou a exibir 8 componentes); também ocorreu a inclusão do componente da Nota de Professores Mestres na dimensão de avaliação do corpo docente vinculado aos cursos.

A segunda revisão se deu em 2011, quando a Portaria Normativa n ${ }^{\circ}$ 40/2007 foi republicada em 2010, instituindo a dispensa da participação de alunos ingressantes a partir do ENADE 2011, em face da ampliação do Exame Nacional do Ensino Médio (ENEM) (BRASIL, 2014a), momento em que a Nota dos Ingressantes do ENADE (NI) foi retirada do cálculo do CPC. Além disso, uma readequação do cálculo do IDD foi necessária, de forma a incluir o desempenho médio dos estudantes no ENEM.

Em 2013 foi instituído um grupo de trabalho, composto por especialistas da área (BRASIL, 2014a) para rever o formato do Questionário do Estudante do ENADE, de forma a 
fazer com que sejam produzidos "insumos de melhor qualidade e maior quantidade para o levantamento das percepções dos estudantes acerca das condições educacionais de seus processos educativos" (BRASIL, 2014a, p. 9). Dessa maneira, já na edição de 2013, foi aplicada uma nova versão do Questionário do Estudante no ENADE, com significativas mudanças, que ampliaram as fontes de percepção discente de dois itens para 42, e incluindo, além de novas percepções sobre Organização Didático-Pedagógica e Infraestrutura, também em relação às Oportunidades de Ampliação da Formação Acadêmica e Profissional ${ }^{70}$.

Com isso, após diversos estudos e análises envolvendo pesquisadores e gestores do INEP, além de especialistas pesquisadores da área de avaliação, a forma de cálculo do CPC novamente se alterou em 2013, para adequar-se às novas fontes de percepção discente, agora disponíveis nas respostas ao Questionário. Assim, o peso de $15 \%$ referente ao total da nota do CPC dedicada à percepção discente, que era desdobrado em 7,5\% para o quesito Organização Didático-Pedagógica e 7,5\% para Infraestrutura, foi redistribuído. A nota referente à Organização Didático-Pedagógica permaneceu com o peso de 7,5\%; porém, a nota relativa à Infraestrutura reduziu-se a $5 \%$, com o acréscimo da nota referente às Oportunidades de Ampliação da Formação Acadêmica e Profissional (2,5\%).

O INEP, que realizou uma análise comparativa das três versões de composição do CPC (ou seja, as versões de 2007, 2008 e 2011), defende que

[...] os seus componentes (insumos) sempre mantiveram vinculação com três dimensões de avaliação da qualidade de cursos de graduação: (a) Desempenho dos Estudantes; (b) Corpo Docente e (c) Percepção Discente sobre as Condições do Processo Formativo. Destaca-se que [...] alguns dos componentes foram revistos desde a criação do CPC, mas mantiveram-se inalteradas as dimensões de avaliação da qualidade (BRASIL, 2014a, p. 8).

Por outro lado, com o levantamento bibliográfico realizado sobre o tema, foi possível perceber que as concepções que norteiam sua relação com o SINAES e, até mesmo os próprios cálculos e mudanças metodológicas do Conceito Preliminar de Curso, desde sua criação, são muito discutidos e questionados. Nesse sentido, é importante não apenas entender o indicador de qualidade tecnicamente, mas compreender seu processo de construção como um resultado de decisões que possuem contexto político, a fim de trazer novos questionamentos para o debate. De acordo com Barreyro (2008b, p. 864, grifo da autora), “como os estatísticos nos

\footnotetext{
${ }^{70}$ Para mais detalhes, ver os Questionários do Estudante do ENADE de 2012 e 2013, disponíveis no Anexo B deste trabalho.
} 
dizem, essas construções, ponderações e escolhas também não são inocentes, neutras, nem apenas técnicas".

Alguns autores alertam para a falta de associação do CPC com os critérios norteadores do SINAES, inclusive pela questão já mencionada anteriormente, da diminuição das visitas in loco nos cursos avaliados, questão tida como obrigatória na lei do Sistema. A instituição do CPC, mediante a publicação da Portaria Normativa $n^{\circ} 4$ de 2008, foi vista como uma prática que sinalizou, por parte do MEC, "apenas uma questão operacional decorrente da implementação do SINAES, e não uma mudança central que retoma velhas concepções e discussões sobre os modelos de avaliação da educação superior no país" (BARREYRO e ROTHEN, 2014, p.70).

Para Barreyro e Rothen $(2011,2014)$, a proposta original do SINAES ensaiou uma grande mudança na avaliação da educação superior brasileira, especialmente na conciliação de diferentes práticas avaliativas; porém, a partir de 2008, a ênfase nos índices acabou por centrar um exame de larga escala (o ENADE) como referência para a regulação do sistema. Para Dias Sobrinho (2008a, p. 821), “a avaliação institucional, que era central no SINAES, se torna periférica [...] O ENADE e o estudante passam a ser as principais fontes de informação para a formulação dos índices de qualidade".

A emergência da instituição do CPC também rendeu diversos questionamentos envolvendo a construção e o cálculo do indicador. Autores como Schwartzman (2008), Barreyro (2008b) e Rothen e Barreyro (2011) questionaram, à época da criação, os cálculos do indicador, principalmente em relação aos critérios escolhidos para o peso de cada componente na nota final, e também a falta de documentos que fornecessem informações transparentes e sistematizadas sobre o cálculo e as mudanças metodológicas.

As inúmera críticas de pesquisadores, técnicos e especialistas da área de avaliação da educação superior levaram o INEP a mudanças metodológicas no cálculo do CPC (Barreyro e Rothen, 2014), conforme observado. Nesse sentido, especialistas do próprio Instituto publicaram um estudo em 2009, com o intuito de analisar os indicadores de qualidade estabelecidos no âmbito do SINAES. Esses especialistas avaliaram que "por ser um indicador composto, o CPC tem recebido a crítica de juntar coisas muito diferentes e, assim, ser um indicador sem sentido" (FERNANDES et al., 2009, p. 17). Na ocasião, os autores propuseram algumas mudanças referentes ao cálculo.

Além disso, o CPC recebe críticas por se basear de forma demasiada nos insumos do ENADE, já que em 2012, 55\% da nota final do CPC referia-se única e exclusivamente ao 
desempenho dos estudantes, e mais $15 \%$ estava relacionado às respostas dos discentes em relação a infraestrutura e organização didático-pedagógica dos cursos. Se somarmos os percentuais, $70 \%$ da nota do CPC estava inteiramente relacionada, de alguma maneira, aos discentes. Rothen e Barreyro (2011, p. 31) problematizam que o INEP definiu os insumos básicos do CPC com a "compreensão de que os insumos que teriam maior impacto sobre a qualidade dos cursos são aqueles que tem maior influência no resultado do ENADE", e por meio deste raciocínio, após diversas análises técnicas, o Instituto teria chegado aos insumos mencionados para compor o CPC. Entretanto, tal situação gera um questionamento em que “estranhamente, o critério para a escolha dos insumos mais importantes é a sua influência no desempenho na prova. Se o ENADE define os insumos a serem utilizados, porque não se utiliza apenas o resultado da prova?” (ROTHEN e BARREYRO, 2011, p. 31).

Além disso, acrescenta-se a esse quadro que "o resultado na prova depende também da motivação e preparação específica dos estudantes para realizar o exame, das condições da aplicação, da sorte, etc.” (FERNANDES et al., 2009, p. 7). Segundo os mesmos autores, ainda, outros fatores podem enviesar tanto a nota dos concluintes de um curso (alguns cursos, por exemplo, atraem bons alunos), quanto a nota do Indicador de Diferença entre os Desempenhos Observado e Esperado (IDD). Para Dias Sobrinho (2008a, p. 822), "não há teoria educacional que sustente que o desempenho de um estudante numa prova seja plena garantia de aprendizagem, nem de que o resultado de um conjunto de estudantes num exame seja igual à qualidade de um curso".

Por outro lado, segundo o INEP, na concepção do CPC, "a soma dos pesos das medidas NC e NIDD deve ser maior que a soma dos pesos das variáveis de insumo - NF, NO, NPD, NPM e NPR ${ }^{71}$ " (BRASIL, 2012c, p. 11). Por outro lado, o Instituto afirma que as variáveis relacionadas aos insumos tenderiam a ser mais estáveis, reduzindo a possibilidade de variância dos resultados de indicadores relativos ao desempenho dos estudantes, do ENADE e do IDD (BRASIL, 2014a).

A questão relacionada aos insumos que compõem o CPC, obtidos por meio das respostas dos alunos (ou seja, baseando-se na avaliação discente), para os quesitos de infraestrutura e organização didático-pedagógica dos cursos, é questionada por Rothen e Barreyro (2011). Essa situação revela uma limitação do CPC, pois

\footnotetext{
${ }^{71}$ Nota de Concluintes (NC), Nota do Indicador de Diferença entre os Desempenhos Observado e Esperado (NIDD), Nota de Infraestrutura (NF), Nota de Organização Didático-Pedagógica (NO), Nota de Professores Doutores (NPD), Nota de Professores Mestres (NPM) e Nota sobre Regime de Trabalho Parcial / Integral (NPR).
} 
[...] ouvir a percepção do aluno é lúcido e desejável. Contudo, tomá-la como referência para a regulação do sistema parece absurdo [...] assume-se que a avaliação discente é suficiente, contrariando a prática do Ministério de conduzir a avaliação dos insumos por especialistas de áreas ou de avaliação (ROTHEN e BARREYRO, 2011, p. 31).

Mais recentemente, em 2013, conforme mencionado, o CPC passou a incluir, ainda, outro componente relacionado à percepção discente (as respostas no Questionário ENADE sobre o tema Oportunidades de ampliação da Formação Acadêmica e Profissional).

A própria Nota Técnica do INEP referente ao Cálculo do Conceito Preliminar de Curso de 2011, publicação que apresentou estudos técnicos que fundamentaram a mudança de metodologia do indicador daquele ano, havia indicado como recomendações para o cálculo dos próximos anos, incluindo "empregar uma única metodologia de cálculo para os indicadores durante os três anos de duração do ciclo de avaliação do SINAES, para que todas as áreas de conhecimento sejam avaliadas de forma semelhante" (BRASIL, 2012c, p. 13), além de apontar a necessidade de pesquisas futuras que visem melhorar "a qualidade dos insumos utilizados no CPC" (BRASIL, 2012c, p. 13). Lacerda e Ferri (2015) sugeriram mudanças no CPC, principalmente em relação à revisão de questões existentes no Questionário do Estudante no ENADE e à construção de CPCs específicos, que levem em consideração a heterogeneidade das organizações acadêmicas e categorias administrativas das IES. Nesse sentido, para os autores, seria importante "dispor de um conjunto amplo e diverso de indicadores de avaliação para a qualidade institucional, e assim respeitar a diversidade do sistema de educação superior do Brasil" (LACERDA e FERRI, 2015, p. 142, grifo dos autores).

A mudança de metodologia, ocorrida nos anos de 2008, 2011 e 2013, ainda revela uma dificuldade, ou até mesmo impossibilidade de comparações anuais e produção de séries históricas com o indicador, já que além da limitação em relação aos resultados do CPC, que são divulgados anualmente, que possuem cálculos diferentes, há também a restrição em torno das áreas que são avaliadas pelo ENADE. São realizadas avaliações apenas a cada três anos para cada conjunto de cursos, ou seja: o CPC de 2012, utilizado neste trabalho, somente seria comparável ao de 2009, pois as mesmas áreas foram avaliadas nas duas edições. Porém, com a mudança de metodologia, tal prática se tornou dificultada.

Soma-se a essa questão o momento da divulgação dos resultados do CPC (realizada anualmente pelo INEP). Os dados são disponibilizados por meio de planilha eletrônica, em formato Microsoft Excel, contendo a nota final de cada unidade de observação, bem como as notas obtidas de cada componente que engloba o cálculo. Entretanto, a nota dos cursos que 
possuem oferta nas modalidades presencial e a distância é divulgada de maneira unificada, considerando a soma dos estudantes das duas modalidades e seus respectivos resultados (BRASIL, 2016h). Tal situação pode dificultar, em certa medida, a análise individual de cada unidade de observação e das particularidades de cada curso.

Apesar disso, a sinalização da Nota Técnica de 2012 do INEP, acerca da necessidade de uniformar os pressupostos metodológicos mostra que o CPC encontra-se, ainda, em processo de transformação e aprimoramento, assim como diversos aspectos do próprio SINAES $^{72}$.

É importante salientar que o CPC possui, atualmente, um peso significativo enquanto indicador de qualidade vigente no sistema de avaliação da educação superior brasileira, considerando seu impacto para a renovação de reconhecimento de cursos superiores especialmente diante de um segmento que se caracterizou pela grande expansão, majoritariamente no setor privado, processo do qual surgiu a necessidade intrínseca de avaliação e controle da qualidade da educação superior. A ênfase nos índices para regular o sistema, que possui menor impacto nas IES públicas - em que, na prática, o desempenho dos alunos costuma ser acima dos níveis exigidos (BARREYRO e ROTHEN, 2014) -, por outro lado é muito importante para as IES privadas, pois

[...] resultados menores aos exigidos significam não apenas monitoramento via visitas de especialistas e eventuais compromissos de melhoria, mas também impedimentos para a participação no Programa Universidade para Todos (ProUni) e em solicitação de créditos junto ao BNDES. Ainda, os resultados acabam se tornando um selo de qualidade e são utilizados para marketing institucional (BARREYRO e ROTHEN, 2014, p. 73)

Além disso, como os resultados são divulgados para toda a sociedade brasileira, os resultados do CPC, bem como dos outros indicadores de qualidade divulgados pelo INEP a partir da realização do ENADE, se por um lado favorecem a construção de rankings e estimulam a competitividade entre as IES, também podem ser utilizados para outros tipos de comparação entre as IES e os cursos. O uso de um indicador de caráter quantitativo, embora encontre-se o risco de não refletir a totalidade do que se pretende avaliar, pode ser uma ferramenta útil para realizar pesquisas e comparações mais abrangentes, inclusive em âmbito nacional. Nesse sentido, para Bittencourt, Casartelli e Rodrigues (2009),

Contudo, apesar das críticas, não há como prescindir de uma avaliação do aprendizado de alunos por meio de exames ou provas em avaliações de larga

\footnotetext{
${ }^{72}$ Para mais detalhes, ver a seção 1.3 do Capítulo 1 - Educação Superior, Avaliação e Qualidade, sobre o SINAES.
} 
escala. Portanto, há que se defender, mesmo que de forma parcial, a realização do ENADE, sustentando que o pleno entendimento da composição dos indicadores derivados desse exame pode trazer valiosas informações e insights às instituições envolvidas (BITTENCOURT, CASARTELLI e RODRIGUES, 2009, p. 670)

Entretanto, os autores apontam uma situação mais desejável, em que "agregar os resultados do ENADE e das avaliações interna e externa, seria, sem dúvida, um passo importante para a retomada da proposta original do SINAES" (BITTENCOURT, CASARTELLI e RODRIGUES, 2009, p. 679).

Em termos operacionais, o Conceito Preliminar de Curso de 2012 gerou resultados para 8.184 cursos, distribuídos em 7.077 Unidades de Observação, em 1.762 Instituições de Ensino Superior. No panorama geral, 71,6\% dos cursos apresentaram desempenho satisfatório, com os conceitos 3, 4 e 5. Ou seja, 28,4\% dos cursos avaliados foram considerados insatisfatórios, e deveriam passar por avaliação presencial para renovação de reconhecimento. Em 2013, foram abrangidos pelo indicador 4.529 cursos, em 4.319 Unidades de Observação em 1.025 IES, sendo que 11,64\% dos cursos registraram conceitos insatisfatórios (1 e 2). Não foi encontrada divulgação oficial sobre a quantidade de cursos que passam por avaliações presenciais anualmente, nem quantos são oficialmente suspensos com base nas medidas de regulação e supervisão por parte do MEC. Em dezembro de 2013, o então Ministro da Educação, Aloísio Mercadante, anunciou que 270 cursos encontravam-se com o ingresso de novos estudantes suspenso, em função de terem registrado CPC insatisfatório em 2009 e 2012, o que representou um corte de 44.069 vagas nas áreas avaliadas (BRASIL, 2013b).

\subsection{O ProUni e os resultados de Avaliação de cursos}

Os resultados de avaliações de cursos no SINAES são dados importantes para o ProUni, já que o Programa exige alguns critérios de avaliação dos cursos superiores que dele participam, para que seja possível realizar a oferta de bolsas. A Lei do ProUni ( ${ }^{\circ} 11.096$, de 13 de janeiro de 2005) determina que

O Ministério da Educação desvinculará do ProUni o curso considerado insuficiente, sem prejuízo do estudante já matriculado, segundo critérios de desempenho do Sistema Nacional de Avaliação da Educação Superior SINAES, por duas avaliações consecutivas, situação em que as bolsas de estudo do curso desvinculado, nos processos seletivos seguintes, deverão ser redistribuídas proporcionalmente pelos demais cursos da instituição, 
respeitado o disposto no art. $5^{\circ}$ desta Lei (BRASIL, 2005a, Art. $7^{\circ} \S 4^{\circ}$, grifo meu).

Vale ressaltar que essa redação foi dada pela Lei $n^{\circ} 11.509$, de 20 de julho de 2007. A redação da lei original do ProUni previa a desvinculação dos cursos considerados insuficientes por três avaliações consecutivas, ou seja, era menos exigente em relação à exclusão de cursos do processo seletivo.

No entanto, não foi encontrada, até o momento, na legislação relativa ao ProUni a exata determinação de quais indicadores são utilizados para considerar um curso insuficiente em relação às Instituições de Ensino Superior que aderem ao Programa, entre os que o SINAES oferece, tais como: o Conceito do Exame Nacional de Desempenho dos Estudantes (ENADE), o Índice Geral de Cursos (IGC), o Conceito Preliminar de Curso (CPC), o Conceito de Curso (CC), etc. Somente foram encontradas referências sobre o assunto nas Portarias Normativas que são publicadas semestralmente, para regulamentar os procedimentos de adesão de mantenedoras de IES, em que há uma menção em torno da necessidade de avaliação dos cursos para oferecimento de bolsas adicionais (as que são oferecidas pelas instituições, além das obrigatórias por lei) - mas não foi identificada nenhuma menção sobre as bolsas regulares.

No caso do oferecimento dessas bolsas adicionais, resgata-se o trecho disposto em uma dessas Portarias Normativas semestrais, como por exemplo, a que regulamentou o processo de adesão de mantenedoras para o processo seletivo do segundo semestre de 2014:

Art. $6^{\circ}$ Somente poderão ser ofertadas bolsas adicionais nos cursos presenciais com conceito maior ou igual a 3 (três) no Sistema Nacional de Avaliação da Educação Superior - Sinaes, instituído pela Lei nº 10.861, de 14 de abril de 2004.

$\S 1^{\circ}$ Para fins da aferição do conceito referido no caput deste artigo, serão considerados:

I - o Conceito de Curso - CC; ou do CC; ou

II - o Conceito Preliminar de Curso - CPC, na hipótese de inexistência

III - o conceito obtido pelo curso no Exame Nacional de Desempenho dos Estudantes - Enade, na hipótese de inexistência do CC e do CPC.

$\S 2^{\circ}$ Observada a ordem prevista no parágrafo anterior, serão considerados, sempre, dentre os conceitos publicados, os mais recentes.

$\S 3^{\circ} \mathrm{O}$ curso cujo ato regulatório mais recente seja "Autorização", segundo o Cadastro e-MEC, poderá oferecer bolsa adicional até o momento em que obtenha o conceito CC, CPC ou Enade. A partir de então, passará a ser regulamentado conforme o disposto nos $\S \S 1^{\circ} \mathrm{e} 2^{\circ}$ deste artigo.

$\S 4^{\circ}$ As bolsas adicionais eventualmente constantes nos Termos de Adesão ou Termos Aditivos, firmados ao amparo desta Portaria e que não atendam ao disposto no caput, serão bloqueadas e não serão ofertadas aos candidatos no processo seletivo. (BRASIL, 2014c, grifo meu). 
Além disso, vale ressaltar que a legislação que estabelece os indicadores de qualidade e avaliação, utilizados nas avaliações gerais do SINAES, utiliza o termo insatisfatório, e não insuficiente, como é o termo referido na legislação do ProUni, disposto na Lei no 11.096/2005. Ou seja, segundo consta na Portaria Normativa MEC n 40/2010, que versa sobre os conceitos utilizados nos indicadores de qualidade e avaliação da educação superior:

Art. 33-A As avaliações do ciclo avaliativo serão orientadas por indicadores de qualidade e gerarão conceitos de avaliação de instituições e cursos superiores, expedidos periodicamente pelo INEP, em cumprimento à Lei $\mathrm{n}^{\circ}$ 10.861, de 2004, na forma desta Portaria Normativa.

$\S 1^{\circ}$ Os conceitos de avaliação serão expressos numa escala de cinco níveis, em que os níveis iguais ou superiores a 3 (três) indicam qualidade satisfatória. $\S 2^{\circ}$ Os indicadores de qualidade serão expressos numa escala de cinco níveis, em que os níveis iguais ou superiores a 3 (três) indicam qualidade satisfatória e, no caso de instituições também serão apresentados em escala contínua. (BRASIL, 2010a, grifo meu).

A Lei do SINAES, $n^{\circ}$ 10.861/2004, também utiliza o termo insatisfatório para classificar os resultados de avaliações de cursos e instituições, conforme consta no trecho:

Art. 10. Os resultados considerados insatisfatórios ensejarão a celebração de protocolo de compromisso, a ser firmado entre a instituição de educação superior e o Ministério da Educação, que deverá conter: I - o diagnóstico objetivo das condições da instituição;

II - os encaminhamentos, processos e ações a serem adotados pela instituição de educação superior com vistas na superação das dificuldades detectadas; III - a indicação de prazos e metas para o cumprimento de ações, expressamente definidas, e a caracterização das respectivas responsabilidades dos dirigentes;

IV - a criação, por parte da instituição de educação superior, de comissão de acompanhamento do protocolo de compromisso. (BRASIL, 2004b, grifo meu).

Foi observado também que, no Decreto Ponte, $\mathrm{n}^{\circ}$ 5.773/2006, relativo ao exercício das funções de regulação, supervisão e avaliação da educação superior, refere-se o termo insatisfatório para designar os resultados de avaliação do SINAES (BRASIL, 2006a, Art. 23). Portanto, enfatiza-se que não foram encontradas, durante o levantamento documental, referências na legislação do SINAES a respeito da utilização do termo insuficiente para a classificação dos resultados de avaliação.

Destaca-se neste trabalho, então, que além da legislação relativa ao ProUni não explicitar diretamente qual indicador de qualidade é utilizado para a avaliação de todos os cursos superiores que participam dos processos seletivos, também é necessário observar se de 
fato os termos insatisfatório (constante na legislação do SINAES) e insuficiente (constante na legislação do ProUni) podem ser considerados ou não como critérios sinônimos de avaliação para os cursos de graduação.

\subsection{O ProUni e os resultados do Conceito Preliminar de Curso (CPC) 2012}

Nesta seção, será realizada a análise de dados e a discussão dos resultados sobre a questão da qualidade dos cursos do Programa Universidade para Todos. Para tanto, foram relacionados os resultados de avaliação do Conceito Preliminar de Curso (CPC) com os dados obtidos sobre os cursos que ofereceram bolsas do ProUni.

Antes de prosseguir para a análise, se faz necessário, primeiramente, destacar quais foram os aspectos metodológicos que nortearam o estudo aqui realizado.

\subsubsection{Descrição da metodologia utilizada}

Os dados relativos aos cursos que ofereceram bolsas pelo ProUni foram obtidos, conforme destacado no Capítulo 2, por meio da Lei de Acesso à Informação, resultantes de solicitações junto ao MEC. São informações que identificam quais são os cursos e as Instituições de Ensino Superior com oferta de bolsas, turnos, modalidades de ensino, recortes por Unidade da Federação, por município, por processos seletivos, etc., o que permitiu o desdobramento na análise proposta por esta pesquisa.

Dos dados obtidos sobre o ProUni, foram realizados recortes temporais e geográficos, face à grande quantidade de informações a serem trabalhadas, segundo os respectivos critérios: foi escolhido o processo seletivo do primeiro semestre de 2014, pelo fato de concentrar o maior número de bolsas ProUni ofertadas entre o período disponibilizado; e foram delimitados apenas os cursos com local de oferta no município de São Paulo - SP, pelo fato de o município possuir o maior número de bolsas a cada processo seletivo, sendo portanto bastante representativo.

De posse dessas informações, para que fosse possível concretizar o objetivo proposto pela pesquisa, ou seja: analisar a questão da qualidade dos cursos que participam do ProUni, a escolha neste trabalho foi de realizar uma comparação dentro do âmbito do próprio SINAES (mesmo diante da legislação que não explicita diretamente qual indicador é utilizado como critério de qualidade para avaliação dos cursos superiores oferecidos pelo ProUni). 
Nesse sentido, a opção foi utilizar o Conceito Preliminar de Curso (CPC), pela razão de ser mencionado nas Portarias Normativas semestrais que regulamentam a adesão de mantenedoras ao ProUni, embora versem apenas sobre os critérios de avaliação para os cursos oferecidos por meio de bolsas adicionais. Além disso, também foi escolhido o CPC por considerar seu peso na avaliação da educação superior brasileira, já que é considerado oficialmente o Indicador de Qualidade da Educação Superior voltado aos cursos de graduação. Portanto, a referência de qualidade da educação superior utilizada neste trabalho será a noção de qualidade oficial estabelecida no âmbito do SINAES - questão que, por outro lado, não impede sua posterior problematização.

Em razão do recorte temporal dos dados do ProUni (processo seletivo do primeiro semestre de 2014), foi utilizado o CPC do ano de 2012, que era o que estava disponível no momento desse processo seletivo. Os resultados do CPC foram obtidos por meio de download, no site do INEP (instituto responsável por sua divulgação) de planilhas eletrônicas do Microsoft Excel. O processamento de todos os dados foi realizado utilizando o mesmo software.

Foram, então, utilizadas as variáveis contidas nos dados do CPC de 2012 para estabelecer o cruzamento ${ }^{73}$ com os dados dos cursos do ProUni. Trata-se, portanto, de uma pesquisa de caráter quantitativo, realizada com o uso de dados secundários.

O CPC, conforme mencionado no início deste Capítulo, é divulgado com base nas áreas de enquadramento que foram avaliadas pelo ENADE. Em 2012, estas áreas foram: Administração, Ciências Contábeis, Ciências Econômicas, Design, Direito, Jornalismo, Psicologia, Publicidade e Propaganda, Relações Internacionais, Secretariado Executivo, Tecnologias em: Gestão Comercial, Gestão de Recursos Humanos, Gestão Financeira, Logística, Marketing, Processos Gerenciais e Turismo. Por esta razão, foram selecionados apenas os $\operatorname{cursos}^{74}$ que ofertaram bolsas pelo ProUni no primeiro semestre de 2014, no município de São Paulo-SP, que estavam contemplados nestas áreas de enquadramento do ENADE e em que foi possível identificar o correspondente CPC na planilha do INEP, a saber: Administração (36 cursos), Ciências Contábeis (28 cursos), Ciências Econômicas (7 cursos), Design (4 cursos), Direito (20 cursos), Jornalismo (5 cursos), Psicologia (12 cursos),

\footnotetext{
${ }^{73}$ Quando a tabulação gerou algum tipo de dúvida, como nomes de instituições diferentes por exemplo, consultouse o e-MEC (sistema online das Instituições de Educação Superior e Cursos Cadastrados no MEC) para complementação das informações.

${ }^{74}$ Entende-se, neste trabalho, por "cursos" as Unidades de Observação avaliadas pelo CPC, conforme enunciado na seção 3.1. Nesse sentido, os "cursos" de uma mesma IES, no mesmo município e na mesma área de enquadramento são aglomerados em Unidades de Observação. Portanto, não estão contabilizados no número de "cursos" mencionados neste trabalho, os diferentes turnos e campus existentes, pois a nota é divulgada de maneira unificada.
} 
Publicidade e Propaganda (10 cursos), Relações Internacionais (7 cursos), Secretariado Executivo (6 cursos), Tecnologia em Gestão Comercial (10 cursos), Tecnologia em Gestão Financeira (15 cursos), Tecnologia em Gestão de Recursos Humanos (25 cursos), Tecnologia em Logística (21 cursos), Tecnologia em Marketing (18 cursos), Tecnologia em Processos Gerenciais (13 cursos) e Turismo (6 cursos). No total, foram 243 cursos analisados em relação ao CPC.

Em uma segunda etapa da pesquisa, foi verificada também a possibilidade de uma análise mais específica, envolvendo o resultado (notas) dos componentes ${ }^{75}$ que integram o cálculo do CPC de forma desagregada, em relação aos mesmos cursos do ProUni. Neste estudo, entre as diversas variáveis divulgadas separadamente, foram selecionadas oito para a análise: notas padronizadas ${ }^{76}$ sobre a quantidade de docentes Mestres e Doutores e sobre o tipo de Regime de Trabalho (Integral/Parcial); as obtidas pelos alunos nos quesitos Formação Geral e Componente Específico; do IDD (Indicador de Diferença dentre os Desempenhos Observado e Esperado); e as obtidas nos quesitos Organização Didático-Pedagógica e Infraestrutura. Também foi selecionada uma variável de caracterização desses cursos, divulgada na mesma planilha, sobre a Organização Acadêmica da Instituição de Ensino Superior ofertante.

A análise dos dados que envolvem as notas padronizadas foi realizada utilizando ferramentas da estatística descritiva, com a construção de tabelas de frequências simples. Tal recurso se mostrou necessário especialmente no caso de variáveis qualitativas, tal como são as notas padronizadas - que além de serem contínuas, são produto de cálculo realizado anteriormente. Portanto, o uso de médias simples, por exemplo, poderia distorcer os resultados.

Por fim, dado o caráter de complexidade e nível de detalhamento das informações analisadas, alguns outros detalhes metodológicos serão destacados durante a própria análise dos resultados.

Os resultados obtidos por meio da análise da relação entre os cursos do Prouni e os resultados de avaliação no âmbito do SINAES serão problematizados à luz do levantamento teórico realizado nos capítulos anteriores, envolvendo a bibliografia sobre o ProUni e o debate sobre qualidade e avaliação da educação superior, observados os limites e possibilidades conceituais desta discussão.

\footnotetext{
${ }^{75} \mathrm{O}$ INEP divulga, além das notas gerais do CPC, as notas brutas e notas padronizadas relativas à cada componente que foi avaliado nos cursos superiores, formando um conjunto de variáveis que integram o cálculo final do CPC.

76 Neste estudo foram utilizadas as notas padronizadas, que assim como os resultados finais, também seguem escala de cinco níveis (0 a 5). Para mais informações sobre o processo de padronização de notas, consultar a seção inicial deste Capítulo, sobre o cálculo do indicador.
} 


\subsubsection{Cursos que ofereceram bolsas no processo seletivo do ProUni 1/2014, segundo as faixas de resultados do Conceito Preliminar de Curso (CPC) 2012}

Nesta seção, serão analisados primeiramente os 243 cursos ProUni selecionados (ou seja, relativos ao processo seletivo do primeiro semestre de 2014, com local de oferta em São Paulo-SP) em relação à nota final do CPC (de 1 a 5), desagregando-os por tipo de bolsa ofertada, por grau acadêmico e por áreas de enquadramento.

Após essa etapa, será realizada uma comparação regional, ou seja, entre os 243 cursos selecionados do ProUni e os demais cursos que possuem CPC 2012, desagregando-os entre: os ofertados no município de São Paulo-SP e os ofertados em todo o Brasil. Dessa maneira, esperase obter uma base de comparação que reflita a situação dos resultados de avaliação dos cursos ProUni selecionados, em relação aos resultados e tendências de avaliação regionais e nacionais, evidenciando as semelhanças e as diferenças.

Conforme a Tabela 17, são apresentados os resultados do CPC 2012 de 243 cursos que ofereceram bolsas do Programa Universidade para Todos no primeiro semestre de 2014, no local de oferta do município de São Paulo-SP. Estes cursos representaram 46,4\% (423 de 911) do total de cursos que ofertaram bolsas do ProUni no semestre referido.

Tabela 17 - Distribuição dos cursos que ofereceram bolsas no processo seletivo do ProUni 1/2014, no município de São Paulo-SP, segundo resultados do Conceito Preliminar de Curso (CPC) 2012.

\begin{tabular}{|c|c|c|}
\hline \multirow[t]{2}{*}{ CPC 2012 - Faixa } & \multicolumn{2}{|c|}{$\begin{array}{l}\text { Cursos do ProUni } \\
\text { São Paulo - SP }\end{array}$} \\
\hline & $\mathbf{n}^{\circ}$ & $\%$ \\
\hline CPC 1 & 0 & - \\
\hline CPC 2 & 29 & 11,9 \\
\hline CPC 3 & 130 & 53,5 \\
\hline CPC 4 & 36 & 14,8 \\
\hline CPC 5 & 3 & 1,2 \\
\hline Ato Vencido & 0 & - \\
\hline SC (Sem Conceito) & 15 & 6,2 \\
\hline Sob supervisão & 0 & - \\
\hline Unidade com cursos não reconhecidos até 22/11/2013 & 30 & 12,4 \\
\hline Descredenciada & 0 & - \\
\hline Total geral & 243 & 100 \\
\hline
\end{tabular}

Fonte: E-SIC / Ministério da Educação e INEP (BRASIL, 2014d). Elaboração própria. 
Relacionando os cursos ProUni selecionados, com as respectivas faixas do CPC, é possível observar que quase metade, 53,5\% ou 130 cursos, estão localizados na faixa do CPC 3, considerado resultado satisfatório pelos critérios estabelecidos pelo SINAES. Em seguida, 14,8\% (36 cursos) estão localizados na faixa do CPC 4, 11,9\% (29 cursos) estão na faixa do CPC 2 e apenas 1,2\% (3 cursos) localizam-se na faixa do CPC 5, considerado o Conceito que exibe maior correspondência com os critérios de qualidade exigidos. Observa-se também a quantidade considerável de cursos Sem Conceito (15 cursos, ou 6,2\%) e com ausência de reconhecimento até a data de aferição do CPC (30 cursos, ou 12,4\%).

Desta apresentação de dados inicial, merece destaque a quantidade de cursos predominantemente na faixa 3, ou seja, o mínimo satisfatório do CPC, e pouquíssimos cursos nas faixas dos Conceitos 4 e 5 . Além disso, muitos cursos estão na faixa 2 do CPC, considerada insatisfatória segundo os parâmetros do SINAES. Se considerarmos o termo disposto na legislação do ProUni - insuficiente - como um sinônimo de insatisfatório, estes seriam cursos considerados insuficientes para os critérios de adesão ao ProUni, embora a legislação referente ao Programa atente que é preciso duas avaliações insuficientes consecutivas para que o curso seja descredenciado do Programa. Outro agravante entre estes cursos que ofertaram bolsas pelo ProUni é a quantidade de cursos que estavam Sem Conceito e com status de ausência de reconhecimento, o que traz incertezas sobre a qualidade dos mesmos - se considerarmos os padrões de qualidade estabelecidos pelo CPC.

Antes de aprofundar os resultados dos cursos ProUni selecionados, é importante tecer observações sobre a concentração dos cursos avaliados em torno do Conceito 3, considerando a escala possível de 1 a 5 (quadro que se repetirá diversas vezes durante o trabalho), pois não se pode deixar de mencionar que esta é uma característica intrínseca aos resultados do CPC.

Na seção anterior, foi evidenciado o recurso estatístico de afastamento padronizado, realizado pela equipe técnica do INEP, para obtenção das notas de cada componente. Para Nunes, Fernandes e Albrecht (2014, p. 31), é necessário atentar ao fato de que, com esse processo, "a nota atribuída a cada um dos insumos não é a exata fotografia do curso da instituição, senão uma ponderação das notas obtidas em cada insumo do curso, confrontada com o comportamento nacional naquela área de avaliação". Além disso, no cálculo, as unidades de observação com "valores de afastamento padronizado inferiores a -3,0 e superiores a 3,0 não serão utilizadas como ponto inferior ou superior da fórmula, pelo fato dessas Unidades terem resultados muito discrepantes das demais da sua área (conhecidos como outliers)" (BRASIL, 2013a, p. 11, grifo no original). Esses processos acabam gerando maior homogeneização das 
notas, concentrando-as especialmente em torno da faixa 3 do indicador, o que também acontece com outros indicadores relativos ao SINAES (BITTENCOURT et al., 2008).

Como nesta pesquisa a opção foi por utilizar os resultados do CPC conforme disponibilizados pelo INEP (ou seja, já calculados e padronizados), é importante salientar que, por conta desse processo estatístico, os dados apresentados podem indicar tendência de distribuição semelhante, não apenas nas faixas da nota final do CPC, mas também das notas relacionadas aos componentes do indicador. Entretanto, como será observado na comparação dos cursos, mesmo apresentando tendência de distribuições semelhantes, foram identificadas diversas diferenças entre os grupos de cursos analisados (cursos ProUni selecionados e demais cursos) em relação aos resultados, tanto da nota final, como das notas dos componentes do CPC, os quais serão apresentados ao longo desta seção.

Na Tabela 18 estão os cursos ProUni selecionados, por tipo de bolsa ofertada durante o processo seletivo - se é integral (100\%) ou parcial (50\%). No cruzamento de variáveis, foi possível identificar em qual faixa do CPC se concentra o maior número de bolsas ofertadas pelos cursos selecionados. Os 243 cursos selecionados ofertaram, juntos, 9.786 bolsas, um total de 36,4\% em relação ao total de oferta de bolsas pelo ProUni no município de São Paulo-SP no período analisado, o primeiro semestre de 2014 (26.841 bolsas). Deste total de 9.786 bolsas, aproximadamente $62 \%$ (6.099) são bolsas parciais e 38\% (3.687) são bolsas integrais.

Tabela 18 - Distribuição das bolsas ofertadas pelos cursos selecionados no processo seletivo do ProUni 1/2014, no município de São Paulo-SP, por tipo de bolsa, segundo resultados do Conceito Preliminar de Curso (CPC) 2012.

\begin{tabular}{ccc|cc}
\hline \multirow{2}{*}{ CPC - Faixa } & \multicolumn{2}{c|}{ Bolsas Integrais } & \multicolumn{2}{c}{ Bolsas Parciais } \\
\cline { 2 - 6 } & $\mathbf{n}^{\circ}$ & $\begin{array}{c}\text { \% do total } \\
\text { de bolsas }\end{array}$ & $\mathbf{n}^{\circ}$ & $\begin{array}{c}\% \text { do total } \\
\text { de bolsas }\end{array}$ \\
\hline 2 & 391 & $4,0 \%$ & 461 & $4,7 \%$ \\
3 & 1.982 & $20,3 \%$ & 4.170 & $42,6 \%$ \\
4 & 941 & $9,6 \%$ & 846 & $8,6 \%$ \\
5 & 9 & $0,1 \%$ & 7 & $0,1 \%$ \\
SC & 50 & $0,5 \%$ & 243 & $2,5 \%$ \\
Unidade com cursos não reconhecidos até 22/11/2013 & 314 & $3,2 \%$ & 372 & $3,8 \%$ \\
\hline Total & $\mathbf{3 . 6 8 7}$ & $\mathbf{3 7 , 7 \%}$ & $\mathbf{6 . 0 9 9}$ & $\mathbf{6 2 , 3 \%}$ \\
\hline Total de Bolsas Integrais + Parciais & $\mathbf{9 . 7 8 6}$ & - & - & - \\
\hline
\end{tabular}

Fonte: E-SIC / Ministério da Educação e INEP (BRASIL, 2014d).

Elaboração própria. 
Na comparação do tipo de bolsa ofertada pelos cursos ProUni, por faixa do Conceito Preliminar de Curso, evidencia-se que a grande parte (42,6\% do total, ou 4.170 bolsas) são bolsas parciais e localizadas em cursos da faixa 3 do CPC. Outros 20,3\% (1.982) são bolsas integrais, também localizadas na faixa 3. Portanto, mais da metade $(62,9 \%)$ das bolsas do ProUni ofertadas no período analisado concentram-se em cursos que estão na faixa 3 do indicador de qualidade utilizado como referência, além de serem em sua maioria bolsas parciais. Aliado a este movimento, nota-se que, nas bolsas parciais, há mais cursos com CPC 2 (4,7\% contra 4,0\% nas bolsas integrais), cursos Sem Conceito (2,5\% contra 0,5\%), e unidades com cursos não reconhecidos $(3,8 \%$ contra $3,2 \%)$. Por outro lado, observa-se uma diminuição desse tipo de bolsa na faixa do CPC 4 (8,6\% contra 9,6\% nas bolsas integrais) e no CPC 5 observase uma relação semelhante e diminuta ( $0,1 \%$ nos dois tipos de bolsas).

Portanto, o que se pode identificar nos dados apresentados é que a oferta de bolsas parciais se deu em cursos que obtiveram resultado visivelmente pior em relação ao indicador de qualidade de cursos selecionado. Entretanto, embora entre esses 243 cursos tenha ocorrido maior oferta de bolsas parciais, essas bolsas não são a modalidade mais ofertada na totalidade dos processos seletivos do ProUni. Com exceção do ano de 2008, em todos os outros anos a oferta de bolsas integrais foi maior do que a de parciais $^{77}$.

Na Tabela 19, são apresentados os resultados obtidos no CPC dos cursos ProUni selecionados, segmentados por grau acadêmico de graduação: Bacharelados $^{78}$ e Cursos Superiores de Tecnologia ${ }^{79}$.

\footnotetext{
77 Conforme destacado no Capítulo 2.

${ }^{78}$ Foi possível distinguir que os 243 cursos selecionados para análise são cursos de Bacharelado ou Cursos Superiores de Tecnologia, pois no CPC 2012 foram avaliados apenas cursos desses graus acadêmicos, dentro das respectivas áreas de enquadramento selecionadas neste ano. As áreas tradicionais de Licenciatura foram avaliadas no CPC de 2011. Vale ressaltar que, embora o ProUni possua incentivo aos professores da rede pública de ensino, para concorrer às vagas de cursos de licenciatura, os dados oficiais do Programa (mencionados no Capítulo 2) apontam que os professores correspondem a $1 \%$ do total de bolsistas.

79 Os Cursos Superiores de Tecnologia (CSTs) surgiram no contexto de expansão da educação profissional e tecnológica do país, inicialmente na rede federal e posteriormente no setor privado, com expressivo movimento de expansão desde a década de 1990. Segundo Brandão (2010, p. 68), os CSTs "têm sido a base do crescimento percentual do ensino superior no país, principalmente nas instituições do setor privado". Os CSTs visam características que priorizam a formação para o mercado de trabalho, a curta duração, a flexibilidade e custo inferior em relação aos demais cursos de graduação (ROCHA, 2009). São considerados legalmente cursos de graduação, equiparados aos de licenciaturas e bacharelados, conferindo diploma de Tecnólogo - embora, na prática, haja divergências em relação ao tipo de formação obtida e até mesmo recusas do diploma de Tecnólogo em concursos públicos (ROCHA, 2009).
} 
Tabela 19 - Distribuição dos cursos que ofereceram bolsas no processo seletivo do ProUni 1/2014, no município de São Paulo-SP, segundo resultados do Conceito Preliminar de Curso (CPC) 2012, por grau acadêmico.

\begin{tabular}{l|cc|cc}
\hline \multicolumn{1}{c|}{ CPC 2012 - Faixa } & \multicolumn{2}{c|}{ Bacharelados } & \multicolumn{2}{c}{$\begin{array}{c}\text { Cursos } \\
\text { Superiores de } \\
\text { Tecnologia }\end{array}$} \\
& $\mathbf{n}^{\circ}$ & $\mathbf{\%}$ & $\mathbf{n}^{\circ}$ & $\mathbf{\%}$ \\
\hline CPC 1 & 0 & - & 0 & - \\
CPC 2 & 15 & 10,6 & 14 & 13,7 \\
CPC 3 & 73 & 51,8 & 57 & 55,9 \\
CPC 4 & 31 & 22,0 & 5 & 4,9 \\
CPC 5 & 3 & 2,1 & 0 & 0,0 \\
SC (Sem Conceito) & 7 & 5,0 & 8 & 7,8 \\
Unidade com cursos não reconhecidos até 22/11/2013 & 12 & 8,5 & 18 & 17,7 \\
\hline \multicolumn{1}{c|}{ Total geral } & $\mathbf{1 4 1}$ & $\mathbf{1 0 0}$ & $\mathbf{1 0 2}$ & $\mathbf{1 0 0}$ \\
\hline
\end{tabular}

Fonte: E-SIC / Ministério da Educação e INEP (BRASIL, 2014d).

Elaboração própria.

Conforme a Tabela 19, dos 243 cursos ProUni selecionados, 141 (58,1\%) são cursos de Bacharelado, e 102 (41,9\%) são Cursos Superiores de Tecnologia. É possível perceber que a maior parte dos cursos se concentra na faixa 3 do Conceito Preliminar de Curso; entretanto, nota-se uma diferenciação quando foram analisados em separado os cursos de Bacharelado, e os Cursos Superiores de Tecnologia. Na comparação realizada entre os dois graus acadêmicos de graduação, proporcionalmente, os Tecnólogos acabam apresentando maior quantidade de cursos com Conceitos 3 (55,9\%), em relação aos de Bacharelado (51,8\%); no entanto, os cursos de Tecnologia também apresentam maior número de cursos com Conceitos 2 (13,7\%), considerados insatisfatórios em relação aos critérios de qualidade referenciados, do que, em proporção, os de Bacharelado (10,6\%).

Ainda, é possível identificar que os Cursos Superiores de Tecnologia que ofereceram bolsas pelo ProUni apresentam número bastante reduzido de Conceitos 4 (4,9\%) em relação aos de Bacharelado, que apresentam 22\% dos cursos nessa faixa. Com relação à nota máxima do CPC, o Conceito 5, não há nenhum curso de Tecnologia, enquanto que os de Bacharelado apresentam $2,1 \%$, embora esta seja uma quantidade bastante modesta. Também se destaca, na mesma comparação, que Cursos Superiores de Tecnologia possuem grande quantidade de 
cursos sem reconhecimento (17,7\% contra 8,5\% dos Bacharelados), além de número maior de cursos Sem Conceito $(7,8 \%$ contra $5,0 \%)$, respectivamente.

Portanto, a partir dos dados observados, evidencia-se que os CSTs apresentaram pior resultado nos indicadores de qualidade (considerando a referência do Conceito Preliminar de Curso) em relação aos cursos de Bacharelado. A partir dessa análise, seria necessário observar se, historicamente, os CSTs possuem grande oferta nos processos seletivos do ProUni; entretanto, não foi possível conseguir uma série histórica dessas informações, pelos motivos explicitados anteriormente da falta de divulgação oficial das mesmas. Os dados apresentados no Capítulo 2 deste trabalho contêm essa informação, porém referentes apenas aos processos seletivos do segundo semestre de 2013 e primeiro semestre de 2014, os quais mostraram que os cursos de graduação de Bacharelado são maioria (15 entre os 20 mais ofertados) no primeiro semestre de 2014. Já no segundo semestre de 2013, nota-se maior participação dos CSTs, com 8 cursos entre os 20 mais ofertados (Gestão de Recursos Humanos, Marketing, Logística, Gestão Financeira, Redes de Computadores, Gestão da Tecnologia da Informação, Análise e Desenvolvimento de Sistemas e Gestão da Qualidade, que somaram juntos 23,3\% do total de cursos ProUni no semestre).

A seguir, são apresentados os cursos de Bacharelado e Cursos Superiores de Tecnologia, separados por áreas de enquadramento (Tabelas 20 e 21). 
Tabela 20 - Distribuição dos cursos de Bacharelado que ofereceram bolsas no processo seletivo do ProUni 1/2014, no município de São Paulo-SP, segundo resultados do Conceito Preliminar de Curso (CPC) 2012.

\begin{tabular}{lcccc|cc|c}
\hline & \multicolumn{7}{c}{ Número de cursos com: } \\
\cline { 2 - 7 } \multicolumn{1}{c}{ Área de Enquadramento } & CPC 2 & CPC 3 & CPC 4 & CPC 5 & $\begin{array}{c}\text { SC (Sem } \\
\text { Conceito) }\end{array}$ & $\begin{array}{c}\text { Unidade com } \\
\text { cursos não } \\
\text { reconhecidos } \\
\text { até 22/11/2013 }\end{array}$ & $\begin{array}{c}\text { TOTAL } \\
\text { GERAL }\end{array}$ \\
\hline Administração & 6 & 23 & 3 & 1 & 2 & 1 & $\mathbf{3 6}$ \\
Ciências Contábeis & 5 & 11 & 6 & 1 & 1 & 4 & $\mathbf{2 8}$ \\
Ciências Econômicas & 0 & 4 & 2 & 0 & 0 & 1 & $\mathbf{7}$ \\
Design & 0 & 3 & & 0 & 0 & 1 & $\mathbf{4}$ \\
Direito & 1 & 13 & 4 & 0 & 0 & 2 & $\mathbf{2 0}$ \\
Jornalismo & 1 & 1 & 2 & 0 & 1 & 0 & $\mathbf{5}$ \\
Psicologia & 0 & 5 & 6 & 0 & 0 & 1 & $\mathbf{1 2}$ \\
Publicidade e Propaganda & 2 & 5 & 1 & 0 & 1 & 1 & $\mathbf{1 0}$ \\
Relações Internacionais & 0 & 3 & 2 & 1 & 1 & 0 & $\mathbf{7}$ \\
Secretariado Executivo & 0 & 3 & 2 & 0 & 1 & 0 & $\mathbf{6}$ \\
Turismo & 0 & 2 & 3 & 0 & 0 & 1 & $\mathbf{6}$ \\
\hline TOTAL GERAL & $\mathbf{1 5}$ & $\mathbf{7 3}$ & $\mathbf{3 1}$ & $\mathbf{3}$ & $\mathbf{7}$ & $\mathbf{1 2}$ & $\mathbf{1 4 1}$ \\
\hline
\end{tabular}

Fonte: E-SIC / Ministério da Educação e INEP (BRASIL, 2014d).

Elaboração própria.

Por meio das informações expostas na Tabela 20, é possível perceber que as áreas de enquadramento com o maior número de cursos ProUni dentre os selecionados são: Administração (36 cursos), Ciências Contábeis (28 cursos) e Direito (20 cursos). Além da já observada concentração de cursos de Bacharelado na faixa 3 do CPC, analisando os cursos separados por área de enquadramento, é possível perceber que os cursos de Administração e Direito concentram o maior número de cursos com Conceito 3 (23 e 13 cursos, respectivamente). Ainda no mesmo tipo de comparação, na faixa 2 do CPC, concentram-se as áreas de Administração e Ciências Contábeis (6 e 5 cursos, respectivamente). Na faixa 4 do $\mathrm{CPC}$, as áreas de enquadramento que concentraram mais cursos foram Ciências Contábeis e Psicologia (com 6 cursos cada). Somente três das 11 áreas de enquadramento registraram cursos na faixa 5 do CPC, considerada como a que reflete os melhores resultados: Administração, Ciências Contábeis e Relações Internacionais, com 1 curso cada. Vale ressaltar, também, que 2 cursos ficaram Sem Conceito (SC) na área de Administração, além 4 cursos estarem sem reconhecimento até a data de aferição do CPC na área de Ciências Contábeis, e 2 em Direito. 
Tabela 21 - Distribuição dos Cursos Superiores de Tecnologia que ofereceram bolsas no processo seletivo do ProUni 1/2014, no município de São Paulo-SP, segundo resultados do Conceito Preliminar de Curso (CPC) 2012.

\begin{tabular}{|c|c|c|c|c|c|c|c|}
\hline \multirow[b]{2}{*}{ Área de Enquadramento } & \multicolumn{7}{|c|}{ Número de cursos com: } \\
\hline & CPC 2 & CPC 3 & CPC 4 & CPC 5 & $\begin{array}{l}\text { SC (Sem } \\
\text { Conceito) }\end{array}$ & $\begin{array}{c}\text { Unidade com } \\
\text { cursos não } \\
\text { reconhecidos } \\
\text { até 22/11/2013 }\end{array}$ & $\begin{array}{l}\text { TOTAL } \\
\text { GERAL }\end{array}$ \\
\hline Tecnologia em Gestão Comercial & 1 & 4 & 0 & 0 & 2 & 3 & 10 \\
\hline Tecnologia em Gestão de Recursos Humanos & 4 & 13 & 1 & 0 & 1 & 6 & 25 \\
\hline Tecnologia em Gestão Financeira & 1 & 8 & 2 & 0 & 2 & 2 & 15 \\
\hline Tecnologia em Logística & 4 & 13 & 1 & 0 & 1 & 2 & 21 \\
\hline Tecnologia em Marketing & 3 & 10 & 1 & 0 & 2 & 2 & 18 \\
\hline Tecnologia em Processos Gerenciais & 1 & 9 & 0 & 0 & 0 & 3 & 13 \\
\hline TOTAL GERAL & 14 & 57 & 5 & $\mathbf{0}$ & 8 & 18 & 102 \\
\hline
\end{tabular}

Fonte: E-SIC / Ministério da Educação e INEP (BRASIL, 2014d).

Elaboração própria.

Nota: foi constatado durante o levantamento que o curso de Marketing possuía uma opção de Bacharelado em uma instituição. Porém, a oferta no modo de Cursos Superiores de Tecnologia era maior, portanto permaneceu enquadrado nesta categoria. A nota do CPC da instituição que oferecia os dois tipos de curso não foi considerada.

Na divisão realizada para os Cursos Superiores de Tecnologia (Tabela 21), as áreas de enquadramento com o maior número de cursos ProUni dentre os selecionados são: Tecnologia de Gestão de Recursos Humanos (25 cursos), Tecnologia em Logística (21 cursos) e Tecnologia em Marketing (18 cursos). Foi verificada uma concentração ainda maior dos cursos na faixa 3 do CPC, em relação aos de Bacharelado. Entretanto, analisando a concentração de cursos em relação às faixas do $\mathrm{CPC}$, três áreas de enquadramento (Tecnologia em Gestão de Recursos Humanos, Tecnologia em Logística e Tecnologia em Marketing, com 4, 4 e 3 cursos, respectivamente), concentram cursos na faixa do CPC 2, considerada insatisfatória. Além disso, as mesmas três áreas concentram cursos também na faixa seguinte, CPC 3 (13, 13 e 10 cursos, respectivamente). Na faixa do CPC 4, apenas uma área de enquadramento registrou 2 cursos (Tecnologia em Gestão Financeira) e 2 áreas não registraram nenhum curso (Tecnologia em Gestão Comercial e Tecnologia em Processos Gerenciais). Na faixa do CPC 5, não foi registrado nenhum Curso Superior de Tecnologia dentre os selecionados para a análise. Entre os cursos sem reconhecimento até a data de aferição do CPC, encontram-se 6 cursos na área de Tecnologia em Gestão de Recursos Humanos. 


\subsubsection{Comparações Regionais: Cursos ProUni e demais cursos de São Paulo-SP e do} Brasil

Nesta seção, o objetivo foi realizar uma comparação em nível geográfico, ou seja, entre os 243 cursos do ProUni selecionados para análise neste trabalho - que possuem o recorte de local de oferta no município de São Paulo-SP -, e os demais cursos do país, cujos resultados constam na divulgação do CPC 2012, que totalizam 7.077 cursos (ou unidades de observação), desagregando-os entre os ofertados no município de São Paulo-SP e em todo o Brasil. Dessa maneira, é possível estabelecer uma comparação que reflita a situação dos resultados de avaliação dos cursos ProUni selecionados, em relação aos resultados de avaliação regionais e nacionais, evidenciando quais as tendências, as semelhanças e as diferenças encontradas entre os grupos de cursos.

A seleção de dados que será exposta na Tabela 22, a seguir, será a base de informações para todas as demais comparações regionais que se seguirão durante todo o trabalho.

Tabela 22 - Distribuição dos cursos que ofereceram bolsas no processo seletivo do ProUni 1/2014 no município de São Paulo-SP, em relação aos demais cursos do município e do Brasil, segundo resultados do Conceito Preliminar de Curso (CPC) 2012.

\begin{tabular}{|c|c|c|c|c|c|c|}
\hline \multirow[t]{2}{*}{ CPC 2012 - Faixa } & \multicolumn{2}{|c|}{$\begin{array}{l}\text { Cursos ProUni } \\
\text { São Paulo - SP }\end{array}$} & \multicolumn{2}{|c|}{$\begin{array}{c}\text { Cursos } \\
\text { São Paulo - SP1 }\end{array}$} & \multicolumn{2}{|c|}{$\begin{array}{l}\text { Cursos - } \\
\text { Brasil }^{2}\end{array}$} \\
\hline & $\mathbf{n}^{\circ}$ & $\%$ & $\mathbf{n}^{\circ}$ & $\%$ & $\mathbf{n}^{\circ}$ & $\%$ \\
\hline CPC 1 & 0 & - & 0 & - & 16 & 0,2 \\
\hline $\mathrm{CPC} 2$ & 29 & 11,9 & 37 & 18,1 & 715 & 10,5 \\
\hline CPC 3 & 130 & 53,5 & 83 & 40,7 & 2.944 & 43,1 \\
\hline CPC 3 (sob judice) & 0 & - & 0 & - & 1 & 0,0 \\
\hline $\mathrm{CPC} 4$ & 36 & 14,8 & 23 & 11,3 & 1.382 & 20,2 \\
\hline CPC 5 & 3 & 1,2 & 1 & 0,5 & 96 & 1,4 \\
\hline Ato Vencido & 0 & - & 2 & 1,0 & 4 & 0,1 \\
\hline SC (Sem Conceito) & 15 & 6,2 & 35 & 17,2 & 586 & 8,6 \\
\hline Sob supervisão & 0 & - & 0 & - & 12 & 0,2 \\
\hline Unidade com cursos não reconhecidos até 22/11/2013 & 30 & 12,4 & 23 & 11,3 & 1.062 & 15,5 \\
\hline Descredenciada & 0 & - & 0 & - & 16 & 0,2 \\
\hline Total ge ral & 243 & 100 & 204 & 100 & 6.834 & 100 \\
\hline
\end{tabular}

Fonte: E-SIC / Ministério da Educação e INEP (BRASIL, 2014d). Elaboração própria.

(1): Total de Unidades de Observação em São Paulo-SP avaliadas pelo CPC 2012, excluindo as Unidades de Observação identificadas como ProUni, analisadas na primeira coluna.

(2): Total de Unidades de Observação no Brasil avaliadas pelo CPC 2012, excluindo as Unidades de Observação identificadas como ProUni, analisadas na primeira coluna. 
Gráfico 17 - Distribuição dos cursos que ofereceram bolsas no processo seletivo do ProUni 1/2014 no município de São Paulo-SP, em relação aos demais cursos do município e do Brasil, segundo resultados do Conceito Preliminar de Curso (CPC) 2012.

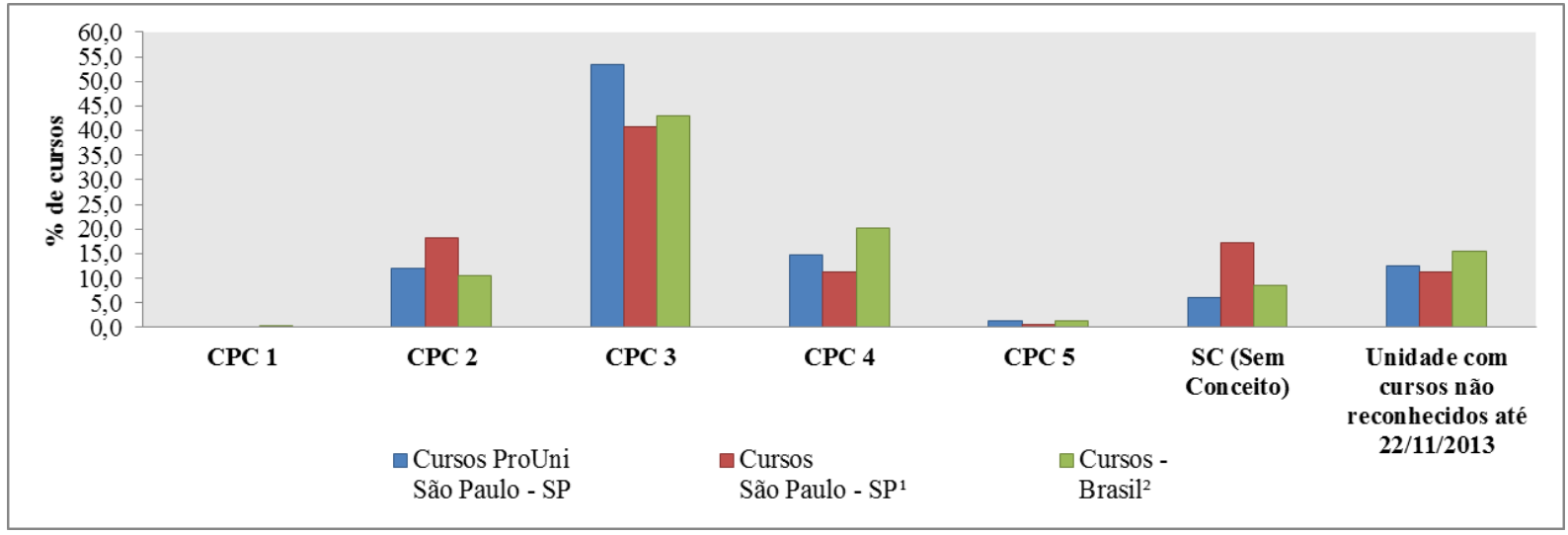

Fonte: E-SIC / Ministério da Educação e INEP (BRASIL, 2014d).

Elaboração própria.

(1): Total de Unidades de Observação em São Paulo-SP avaliadas pelo CPC 2012, excluindo as Unidades de Observação identificadas como ProUni, analisadas na primeira coluna.

(2): Total de Unidades de Observação no Brasil avaliadas pelo CPC 2012, excluindo as Unidades de Observação identificadas como ProUni, analisadas na primeira coluna.

Os 243 cursos ProUni selecionados representaram 3,7\% de todos os cursos avaliados no Brasil pelo CPC no ano referido (que totalizam 7.077 cursos, ou unidades de observação); em relação ao município de São Paulo-SP, a abrangência dos cursos ProUni selecionados representa mais da metade dos cursos $(57 \%)$.

Conforme descrito durante as análises anteriores, realizando a comparação geral com as faixas do CPC (primeira coluna da Tabela 22), observa-se que, no caso dos cursos selecionados que ofereceram bolsas pelo ProUni no primeiro semestre de 2014, quase metade (53,5\% ou 130 cursos) estão localizados na faixa do CPC 3. Em seguida, 14,8\% (36 cursos) estão localizados na faixa do CPC 4, 11,9\% (29 cursos) na faixa do CPC 2, e portanto, considerados insatisfatórios; e apenas 1,2\% (3 cursos) localizam-se na faixa do CPC 5, considerado o Conceito que exibe maior correspondência com os critérios de qualidade exigidos.

Se realizarmos a comparação do grupo ProUni selecionado (243 cursos), com os resultados obtidos entre o grupo dos demais cursos do município de São Paulo - SP (204 cursos), que possuíam o CPC 2012 disponível $^{80}$ (segunda coluna da Tabela 22), foi observado que a distribuição pelas faixas do CPC possui tendência semelhante às exibidas pelos cursos do ProUni analisados: dos 204 cursos, $40,7 \%$ estão na faixa CPC 3; 18,1\% estão no CPC 2; 11,3\% com CPC 4 e apenas $0,5 \%$ com CPC 5. Entretanto, nota-se que, ao realizar a comparação destes

\footnotetext{
${ }^{80} \mathrm{Ou}$ seja, considerando todas as Instituições de Ensino Superior avaliadas, públicas ou privadas, e já excluído o grupo de 243 cursos identificado como ProUni.
} 
204 cursos com os resultados dos cursos identificados como ProUni, em proporção, há mais cursos ProUni concentrados na faixa CPC 3 (53,5\% contra 40,7\%); e há ligeira vantagem dos cursos ProUni nas faixas CPC 4 (14,8\% contra 11,3\%) e CPC 5 (1,2\% contra 0,5\%), além de serem identificados menos cursos na faixa CPC 2 (11,9\% contra 18,1\%).

Ou seja, em proporção, os cursos identificados como ProUni alcançaram resultados melhores (em termos de atendimento aos critérios estabelecidos de qualidade do CPC) nas faixas 2, 4 e 5, do que o observado no quadro dos demais cursos de São Paulo - SP. Além disso, na faixa SC (Sem Conceito) identifica-se, na análise, uma proporção muito menor de cursos do ProUni (6,2\%), do que os demais cursos de São Paulo - SP $(17,2 \%)$.

A fim de ampliar o escopo de análise, foram realizadas comparações, da mesma forma do que com os cursos de São Paulo-SP, para os demais cursos do Brasil avaliados pelo CPC em 2012 (terceira coluna da Tabela 22). Neste caso foram considerados os 6.834 cursos, ou unidades de observação, já excluído o grupo de 243 cursos identificados como ProUni.

$\mathrm{Na}$ análise realizada com os demais cursos ofertados em todo o Brasil, a proporcionalidade se mantém: dos 6.834 cursos, $10,5 \%$ possuem CPC 2, 43,1\% possuem CPC 3, 20,2\% possuem CPC 4, e apenas 1,4\% possuem CPC 5. Há também uma pequena quantidade de cursos $(0,2 \%)$ com CPC 1 , o que não aparece nos grupos analisados anteriormente. Entretanto, se compararmos com os dados das outras colunas, foram observados melhores resultados em relação ao CPC no grupo dos cursos do Brasil, do que nos cursos identificados como ProUni, e até mesmo dos demais cursos de São Paulo-SP; já que, na comparação, em proporcionalidade, foi verificado que no Brasil há menos cursos CPC 2, e mais cursos CPC 4 e CPC 5 do que nos outros grupos. Além disso, há também uma proporção menor de cursos CPC 3 (43,1\% contra 53,5\% do ProUni); entretanto, essa proporção é ligeiramente maior quando se compara com os cursos de São Paulo-SP (43,1\% contra 40,7\%). Contudo, um aspecto positivo é que os cursos ProUni foram menos frequentes do que o restante dos cursos do Brasil, nas faixas Sem Conceito (6,2\% contra 8,6\%, respectivamente) e de unidades sem reconhecimento $(12,4 \%$ contra $15,5 \%)$.

A seguir, utilizando os mesmos cursos ProUni, agora desagregados por área de enquadramento (conforme observado anteriormente nas Tabelas 20 e 21), foi realizada a comparação regional (novamente, com os demais cursos do município de São Paulo-SP e do Brasil) para observar se há semelhanças ou diferenças nos resultados de avaliação do CPC.

Para não estender a análise neste momento, foram escolhidas apenas as cinco áreas de enquadramento que registraram maior número de cursos ProUni (dentre os 243 cursos 
analisados), que são: Administração (36 cursos), Ciências Contábeis (28 cursos), Tecnologia em Gestão de Recursos Humanos (25 cursos), Tecnologia em Logística (21 cursos) e Direito (20 cursos). Os resultados estão expostos nos Gráficos 18, 19, 20, 21 e 22.

Gráfico 18 - Distribuição dos cursos de Administração que ofereceram bolsas no processo seletivo do ProUni 1/2014, no município de São Paulo-SP, em relação aos demais cursos do município e do Brasil, segundo resultados do Conceito Preliminar de Curso (CPC) 2012.

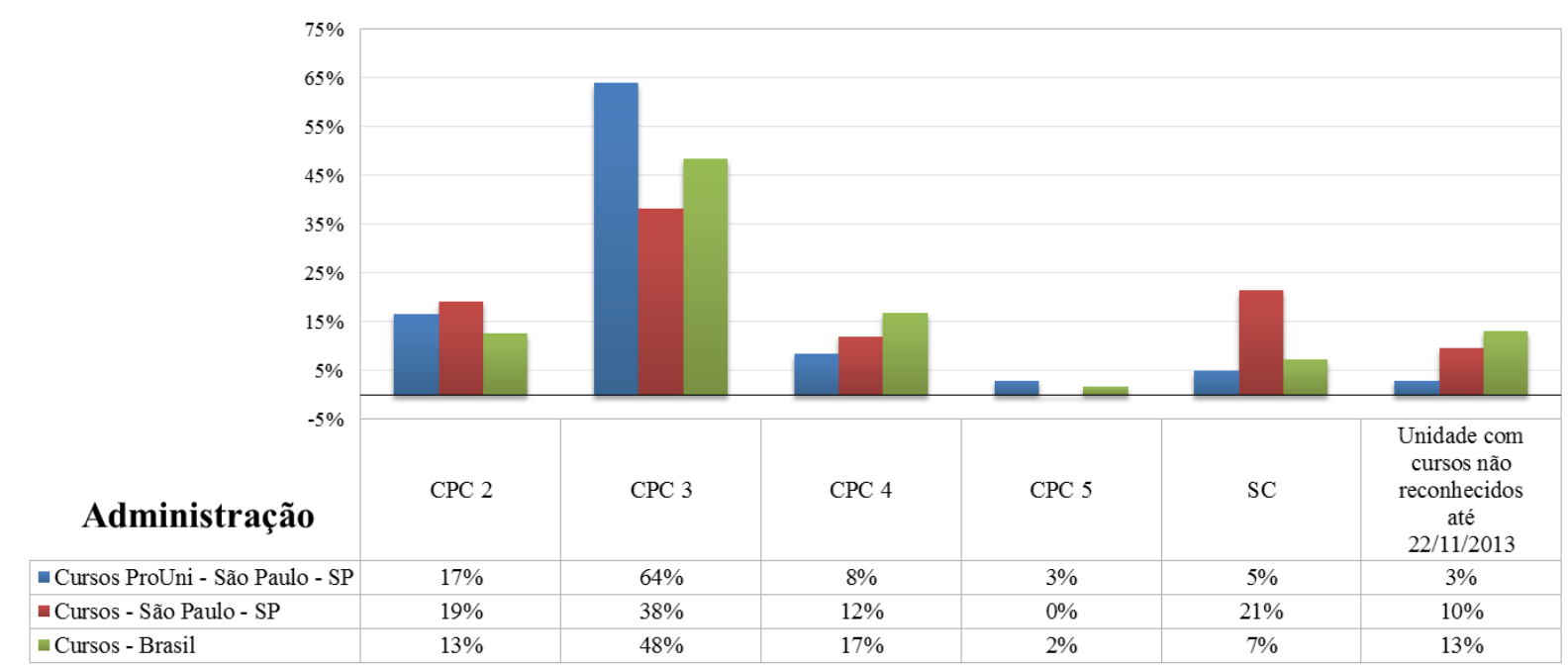

Fonte: E-SIC / Ministério da Educação e INEP (BRASIL, 2014d). Elaboração própria.

Quando foi realizado o desdobramento em torno das cinco áreas de enquadramento selecionadas, é possível observar que em relação aos cursos de Administração (Gráfico 18), há uma concentração muito maior, em proporção, de cursos selecionados do ProUni com CPC 3 (64\%), do que os demais cursos do município (38\%) e do Brasil (48\%). Embora a maioria dos cursos esteja concentrada nessa faixa, percebe-se que há menos cursos ProUni em relação à quantidade dos classificados como Sem Conceito (5\%, contra $21 \%$ do município e $7 \%$ do Brasil), assim como dos não reconhecidos (3\%, contra 10\% no município e $13 \%$ no Brasil). 
Gráfico 19 - Distribuição dos cursos de Ciências Contábeis que ofereceram bolsas no processo seletivo do ProUni 1/2014, no município de São Paulo-SP, em relação aos demais cursos do município e do Brasil, segundo resultados do Conceito Preliminar de Curso (CPC) 2012.

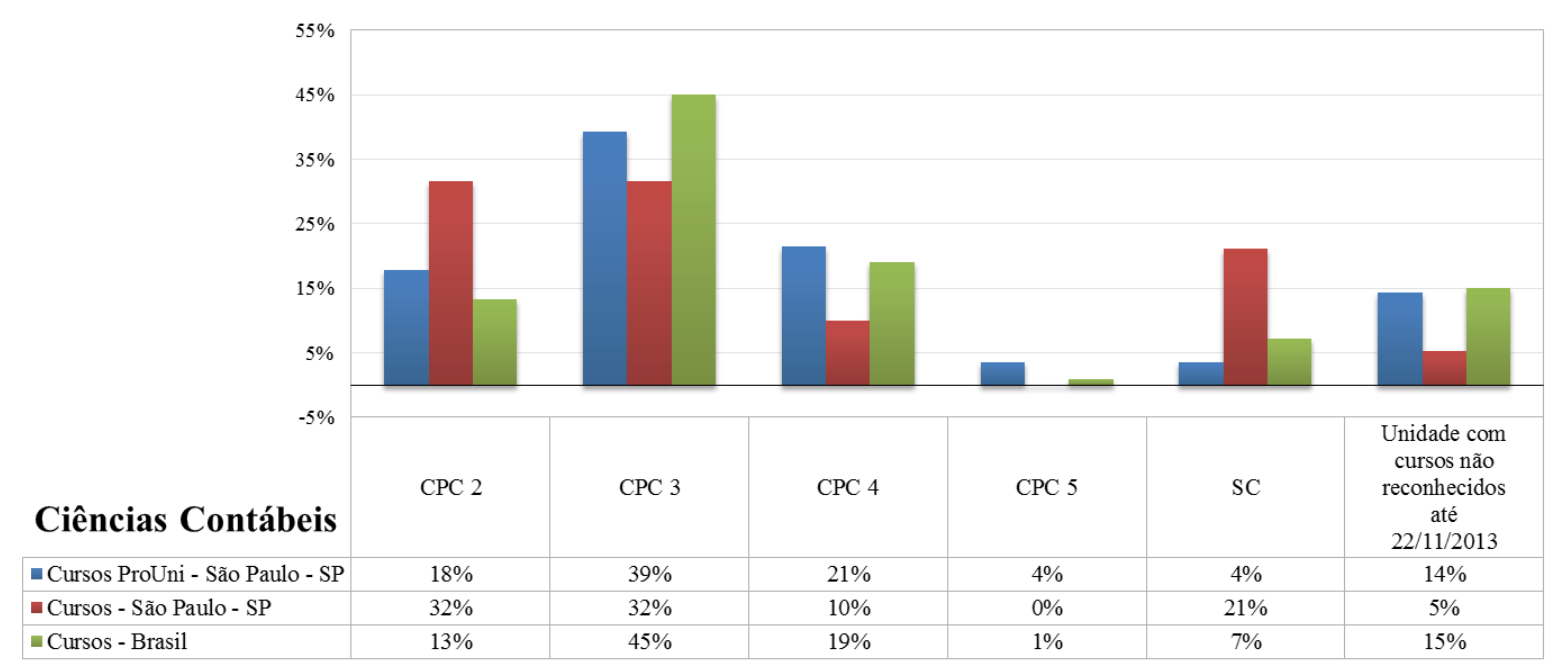

Fonte: E-SIC / Ministério da Educação e INEP (BRASIL, 2014d). Elaboração própria.

Em relação aos cursos de Ciências Contábeis, no Gráfico 19, foi verificada maior incidência de cursos selecionados ProUni na faixa do CPC 3 (39\%), porém em menor concentração do que em relação ao Brasil (45\%), pois identificaram-se também muitos cursos na faixa CPC 2, considerada insatisfatória (18\% ProUni, 32\% em São Paulo-SP e 13\% no Brasil). Nas faixas mais altas do CPC, os resultados mostraram vantagem dos cursos ProUni ( $21 \%$ na faixa 4 , e $4 \%$ na faixa 5), em relação aos demais cursos analisados (no município, são $10 \%$ e $0 \%$, respectivamente; e no Brasil, $19 \%$ e $1 \%$ ).

Gráfico 20 - Distribuição dos cursos de Tecnologia em Gestão de Recursos Humanos que ofereceram bolsas no processo seletivo do ProUni 1/2014, no município de São Paulo-SP, em relação aos demais cursos do município e do Brasil, segundo resultados do Conceito Preliminar de Curso (CPC) 2012.

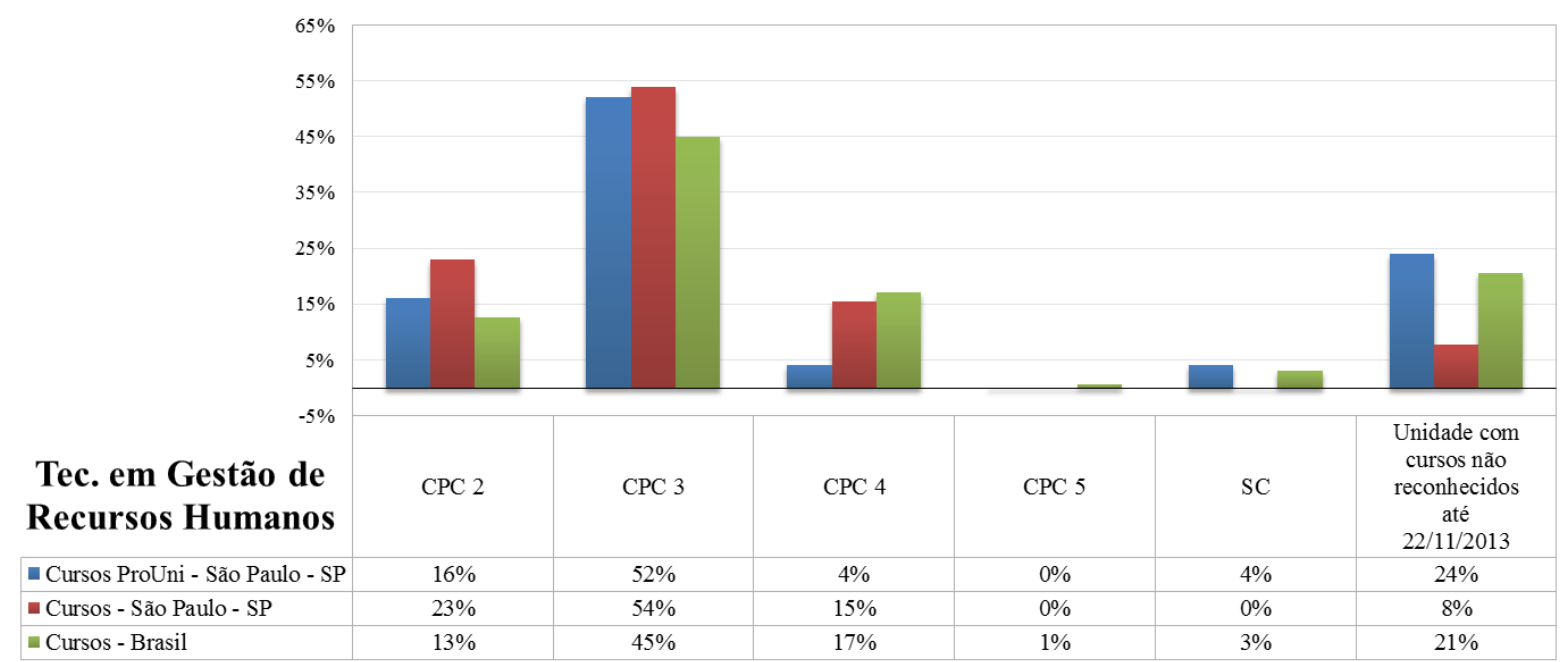

Fonte: E-SIC / Ministério da Educação e INEP (BRASIL, 2014d). Elaboração própria. 
Por outro lado, iniciando a análise em torno de um Curso Superior de Tecnologia (Gestão de Recursos Humanos), no Gráfico 20, primeiramente é possível observar que os resultados são visivelmente inferiores em relação aos dois cursos de Bacharelado analisados anteriormente (Administração e Ciências Contábeis), principalmente pela ausência de cursos com CPC 5 e aumento dos cursos não reconhecidos em todos os grupos analisados (24\% do ProUni, $8 \%$ no município e $21 \%$ no Brasil). Também foi verificado que os cursos ProUni possuem resultados piores na faixa CPC 4 , ou seja, apresentam apenas $4 \%$ entre os cursos analisados, enquanto que os índices no município e no Brasil são maiores - $15 \%$ e 17\%, respectivamente.

A área de Tecnologia em Logística (Gráfico 21) apresenta alta concentração de cursos sem reconhecimento até a data de aferição do CPC 2012 (9\% dos cursos ProUni, 36\% no município e $24 \%$ no Brasil). Por outro lado, observando somente os cursos ProUni, é possível perceber que há uma concentração muito maior na faixa 3 do CPC, com aproximadamente $62 \%$ dos cursos analisados, em relação aos demais grupos (37\% em São Paulo-SP e 38\% no Brasil). Portanto, mais da metade dos cursos de Logística tendem a concentrar-se ou na faixa 3 do CPC, ou entre os cursos que não obtiveram reconhecimento.

Gráfico 21 - Distribuição dos cursos de Tecnologia em Logística que ofereceram bolsas no processo seletivo do ProUni 1/2014, no município de São Paulo-SP, em relação aos demais cursos do município e do Brasil, segundo resultados do Conceito Preliminar de Curso (CPC) 2012.

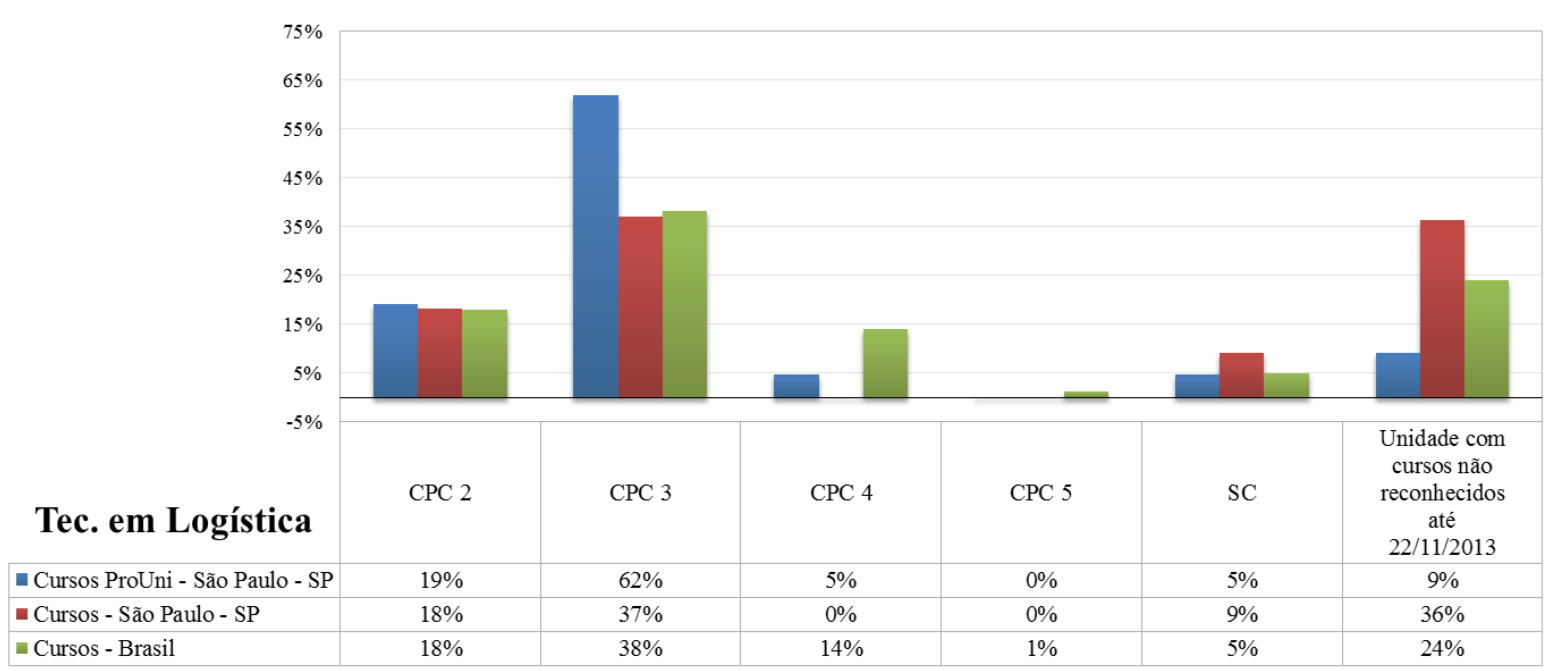

Fonte: E-SIC / Ministério da Educação e INEP (BRASIL, 2014d). Elaboração própria.

A última das cinco áreas de enquadramento analisadas representa os cursos de Direito. No Gráfico 22, foi observado um resultado altamente concentrado na faixa 3 do CPC em todos os grupos de cursos analisados, porém de forma mais intensa no município (65\% dos ProUni, 
92\% do município e 50\% no Brasil). Ainda assim, foi possível observar vantagem dos cursos ProUni selecionados na faixa 4 do CPC (20\%) em relação ao município (8\%) e patamar semelhante em relação ao Brasil (21\%).

Gráfico 22 - Distribuição dos cursos de Direito que ofereceram bolsas no processo seletivo do ProUni 1/2014, no município de São Paulo-SP, em relação aos demais cursos do município e do Brasil, segundo resultados do Conceito Preliminar de Curso (CPC) 2012.

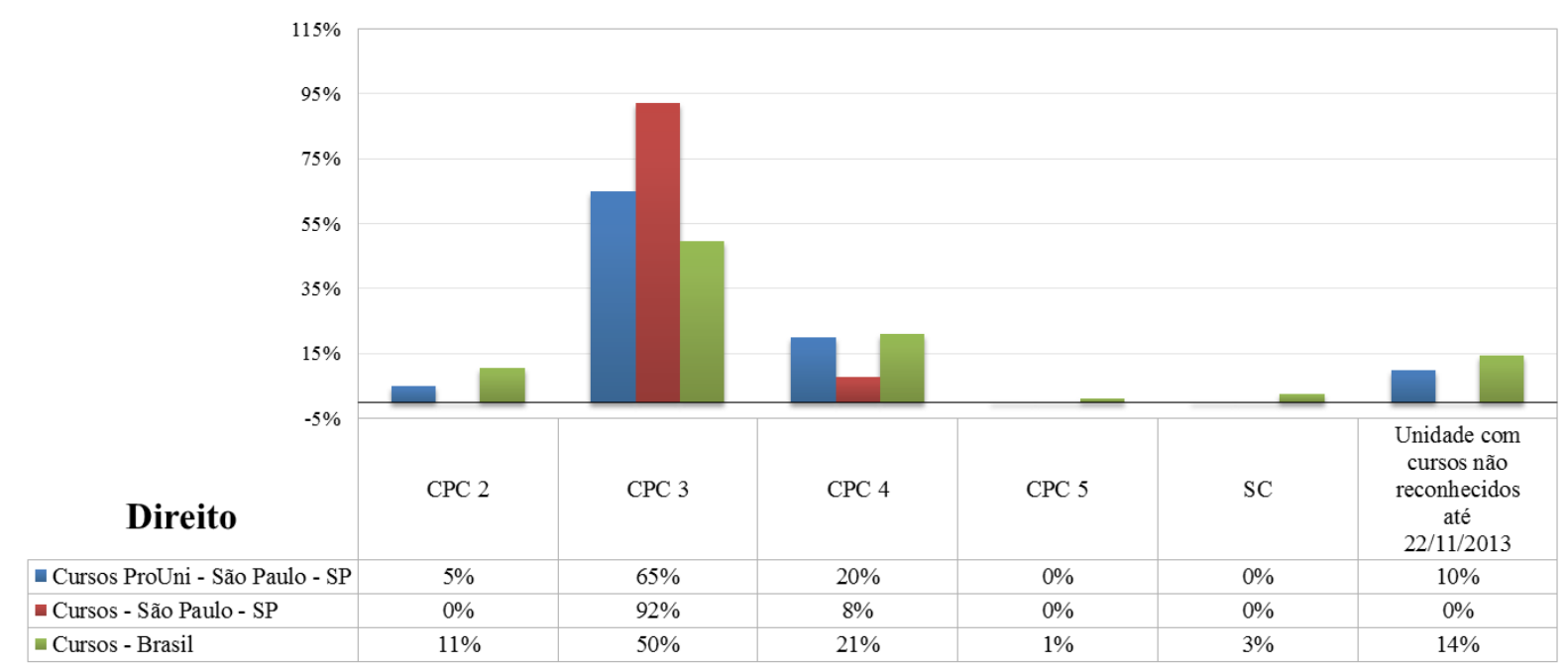

Fonte: E-SIC / Ministério da Educação e INEP (BRASIL, 2014d). Elaboração própria.

Da análise de todos as áreas de enquadramento selecionadas, e seus respectivos cursos, merece destaque a ausência de cursos com CPC 5 em todos os grupos, sendo este considerado o Conceito que possui maior correspondência com os critérios de qualidade exigidos.

Também é importante observar que, das cinco áreas de enquadramento analisadas, três são caracterizadas por ofertar cursos de Bacharelado (Administração, Ciências Contábeis e Direito) e duas áreas ofertaram Cursos Superiores de Tecnologia (Logística e Gestão de Recursos Humanos). Estas são as áreas que apresentaram não apenas a maior incidência entre a quantidade de cursos ProUni selecionados, entre os 243 da análise, mas também, em relação a todos os cursos que ofertaram bolsas nos dois processos seletivos do ProUni analisados no Capítulo 2 deste trabalho ${ }^{81}$. Ou seja, essas áreas representam uma parcela significativa dos cursos que ofereceram bolsas ProUni no período.

Após observar os resultados das análises realizadas até o momento, em síntese, foi possível perceber que a nota final obtida no CPC (1 a 5) apresenta resultados bastante agregados, principalmente por conta do processo de afastamento padronizado, já mencionado

\footnotetext{
${ }^{81}$ Administração, Ciências Contábeis, Direito, Logística e Gestão de Recursos Humanos estão entre os 20 cursos
} que ofertaram mais bolsas nos dois processos seletivos do ProUni (2/2013 e 1/2014) analisados no Capítulo 2. 
anteriormente. Tal situação acaba por se refletir na concentração dos cursos em determinadas faixas, em que aproximadamente metade dos cursos ProUni selecionados (53,5\%), dos cursos de São Paulo-SP (40,7\%) e dos cursos do Brasil (43,1\%) com CPC disponível estão localizados na faixa 3 .

Considerando apenas este resultado geral, seria possível dizer que os cursos ProUni selecionados para a análise acompanham a tendência de resultados de avaliação registrados nos demais cursos do município e do país, a partir do Conceito Preliminar de Curso 2012. Ainda assim, foram registradas diferenças não apenas nos resultados de avaliação entre os cursos ProUni (em relação aos graus acadêmicos, áreas de enquadramento e tipo de bolsa ofertada), mas também na comparação destes em relação aos demais grupos de cursos avaliados pelo CPC - e, em alguns casos, com resultados superiores (em relação ao critério de qualidade escolhido), obtidos pelos cursos do ProUni.

Entretanto, a nota final do CPC não reflete, sozinha, os diversos componentes que são avaliados e que constituem os critérios de qualidade exigidos no processo - e sendo assim, pode não fornecer um retrato mais aprofundado sobre os elementos que são avaliados como indicadores de qualidade nos cursos de graduação. A nota do CPC, conforme detalhado na seção dedicada ao assunto, é obtida com a combinação de diferentes componentes. Embora estes componentes possuam pesos diferentes na composição da nota final ${ }^{82}$, foi verificada a possibilidade e a relevância de observar o resultado de cada variável em separado, a fim de caracterizar e analisar mais profundamente os cursos, bem como os critérios de qualidade considerados na avaliação do indicador selecionado.

Portanto, na próxima seção, serão apresentadas as comparações realizadas, com o intuito de verificar qual foi o resultado obtido dos grupos de cursos selecionados nos resultados de alguns dos componentes que integram o cálculo do Conceito Preliminar de Curso.

\footnotetext{
${ }^{82}$ Neste trabalho, por razões metodológicas, não se problematizou a questão da ponderação dos componentes do CPC em relação ao cálculo da nota final. Portanto, a análise se deu em torno do resultado de cada componente em separado, e não em relação a seu peso e/ou protagonismo na nota final.
} 


\subsubsection{Cursos que ofereceram bolsas no processo seletivo do ProUni 1/2014, segundo os resultados dos componentes do Conceito Preliminar de Curso (CPC) 2012}

Desagregando as informações segundo os componentes do CPC, é possível visualizar os resultados, em forma de notas, obtidos por cada componente que foi avaliado nos cursos superiores, formando um conjunto de variáveis que integram o cálculo final do CPC.

Neste estudo, seguindo os critérios metodológicos apontados anteriormente, entre as diversas variáveis divulgadas separadamente na planilha do Conceito Preliminar de Curso 2012, foram selecionadas oito para a análise: notas padronizadas sobre a quantidade de docentes Mestres e Doutores e sobre o tipo de Regime de Trabalho (Integral/Parcial); as obtidas pelos alunos nos quesitos Formação Geral e Componente Específico; do IDD (Indicador de Diferença dentre os Desempenhos Observado e Esperado); e as obtidas nos quesitos Organização Didático-Pedagógica e Infraestrutura. Por conter informações importantes para a pesquisa, também foi selecionada uma variável de caracterização desses cursos, divulgada na mesma planilha, sobre Organização Acadêmica da Instituição de Ensino Superior ofertante.

Nesta seção serão, então, analisados os 243 cursos ProUni selecionados, em relação aos demais grupos de cursos da comparação regional (São Paulo-SP e Brasil), desagregando-os pelos resultados obtidos nessas variáveis e componentes.

Tabela 23 - Distribuição dos cursos que ofereceram bolsas no processo seletivo do ProUni 1/2014, no município de São Paulo-SP, em relação aos demais cursos do município e do Brasil, por Organização Acadêmica da Instituição ofertante, segundo resultados do Conceito Preliminar de Curso 2012.

\begin{tabular}{|c|c|c|c|c|c|c|}
\hline \multirow[t]{2}{*}{ Organização Acadêmica } & \multicolumn{2}{|c|}{$\begin{array}{l}\text { Cursos Prouni } \\
\text { São Paulo - SP }\end{array}$} & \multicolumn{2}{|c|}{$\begin{array}{c}\text { Cursos } \\
\text { São Paulo - SP }\end{array}$} & \multicolumn{2}{|c|}{$\begin{array}{c}\text { Cursos } \\
\text { Brasil }\end{array}$} \\
\hline & $\mathbf{n}^{\circ}$ & $\%$ & $\mathbf{n}^{\circ}$ & $\%$ & $\mathbf{n}^{\circ}$ & $\%$ \\
\hline Universidade & 113 & 46,5 & 50 & 24,5 & 2.150 & 31,5 \\
\hline Centro Universitário & 64 & 26,3 & 48 & 23,5 & 888 & 13,0 \\
\hline Faculdade & 66 & 27,2 & 105 & 51,5 & 3.753 & 54,9 \\
\hline Instituto Federal de Educação, Ciência e Tecnologia & - & - & 1 & 0,5 & 41 & 0,6 \\
\hline Centro Federal de Educação Tecnológica & - & - & - & - & 2 & 0,0 \\
\hline Total & 243 & 100,0 & 204 & 100,0 & 6.834 & 100,0 \\
\hline
\end{tabular}

Fonte: E-SIC / Ministério da Educação e INEP (BRASIL, 2014d).

Elaboração própria. 
Gráfico 23 - Distribuição dos cursos que ofereceram bolsas no processo seletivo do ProUni 1/2014, no município de São Paulo-SP, em relação aos demais cursos do município e do Brasil, por Organização Acadêmica da Instituição ofertante, segundo resultados do Conceito Preliminar de Curso 2012.

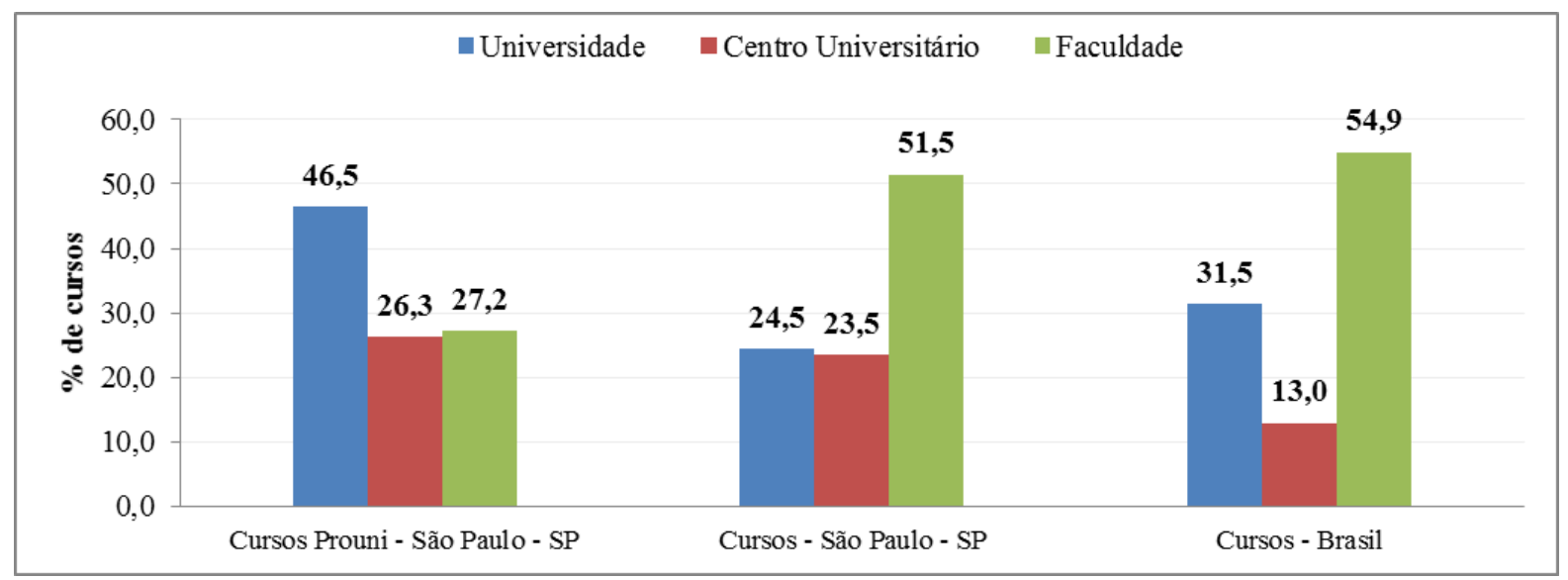

Fonte: E-SIC / Ministério da Educação e INEP (BRASIL, 2014d).

Elaboração própria.

A variável Organização Acadêmica da Instituição de Ensino Superior está inclusa na divulgação dos resultados do CPC com o intuito de caracterização dos cursos (unidades de observação) avaliados anualmente. Realizando um cruzamento entre essas informações e os grupos de cursos selecionados, conforme exibem a Tabela 23 e o Gráfico 23 (este último concentrando as três organizações acadêmicas com maior número de cursos, para melhor visualização), é possível perceber que os cursos ProUni analisados são oferecidos, segundo sua organização acadêmica, em: Universidades (47\%); Faculdades (27\%) e Centros Universitários $(26 \%)$.

Desse modo, constata-se que a concentração em Universidades corrobora o quadro visto anteriormente no Capítulo 2, quando foram apresentados alguns dados sobre o ProUni, em que a oferta do Programa no estado de São Paulo e no município de São Paulo-SP é marcada pela alta concentração em Instituições de Ensino Superior de grande porte, especialmente Universidades integrantes de grandes grupos educacionais ${ }^{83}$. Essa situação acaba reforçando o quadro de pouca diversidade institucional, podendo relacionar-se, inclusive, ao processo de oligopolização do segmento de educação superior - considerando que o recorte geográfico concentra, historicamente, a maior oferta de bolsas do Programa no Brasil.

\footnotetext{
${ }^{83}$ Conforme constatado no Capítulo 2, a concentração de bolsas ofertadas no estado e no município de São PauloSP, no período analisado (primeiro semestre de 2014) se deu em instituições como Universidade São Judas Tadeu (USTJ), Universidade Paulista (UNIP), Universidade Nove de Julho (UNINOVE) e instituições do grupo Anhanguera Educacional (Centro Universitário Anhanguera, Uniderp, UNOPAR).
} 
A questão da concentração em Universidades torna-se ainda mais evidente quando foi realizada a comparação dos 243 cursos ProUni com os demais cursos ofertados no município de São Paulo - SP e no Brasil. Nota-se que, nos cursos de São Paulo-SP e do Brasil há um predomínio muito maior da oferta em Faculdades (51\% e 55\%, respectivamente) do que no ProUni, que apresenta $27 \%$. Tal fato pode estar relacionado à questão de que o setor de educação superior brasileiro é extremamente pulverizado, em termos de IES, concentrando um grande número de instituições de pequeno porte; porém, no caso de políticas com o caráter de renúncia fiscal, como é o caso do ProUni, a oferta costuma se concentrar em instituições educacionais privadas com maior oferta de vagas (ou seja, maior poder de barganha no mercado). É conhecido que o ProUni, conforme apontaram autores como Leher (2004) e Carvalho (2006), promoveu vias de estabilização e expansão de diversas instituições do setor privado, por meio dos incentivos concedidos na forma de isenções fiscais.

Para entender a questão da pulverização de IES e, ao mesmo tempo, concentração de matrículas em poucas instituições, segundo dados do Censo de Educação Superior 2013, foram registradas 2.391 IES em todo o Brasil, sendo 2.016 classificadas como Faculdades (84,3\%). No entanto, as Faculdades concentraram 29,2\% do total de matrículas, enquanto que os Centros Universitários e Universidades concentraram 63,3\%.

Cabe ponderar que o grupo de cursos ProUni selecionados está inteiramente centrado (como local de oferta) do município de São Paulo - SP, em que já se encontra um quadro de maior concentração de cursos ofertados em IES maiores (Universidades e Centros Universitários), muitas vezes pertencentes a grandes grupos educacionais. Tal situação também se refletirá nos dados a seguir, sobre os resultados das notas padronizadas ${ }^{84}$, obtidas pelos cursos nos insumos do CPC relacionados às funções docentes: quantidade de docentes mestres (Gráfico 24) e quantidade de docentes doutores (Gráfico 25).

\footnotetext{
${ }^{84}$ As notas padronizadas que serão analisadas a partir deste momento também são consideradas em escala ordinal (0 a 5), sendo 0 considerado o pior resultado e 5 o melhor resultado. Algumas variáveis apresentaram, também, ausência de valor (sem nota atribuída).
} 
Gráfico 24 - Distribuição dos cursos que ofereceram bolsas no processo seletivo do ProUni 1/2014, no município de São Paulo-SP, em relação aos demais cursos do município e do Brasil, segundo resultados do Conceito Preliminar de Curso 2012 no componente Docentes com Mestrado.

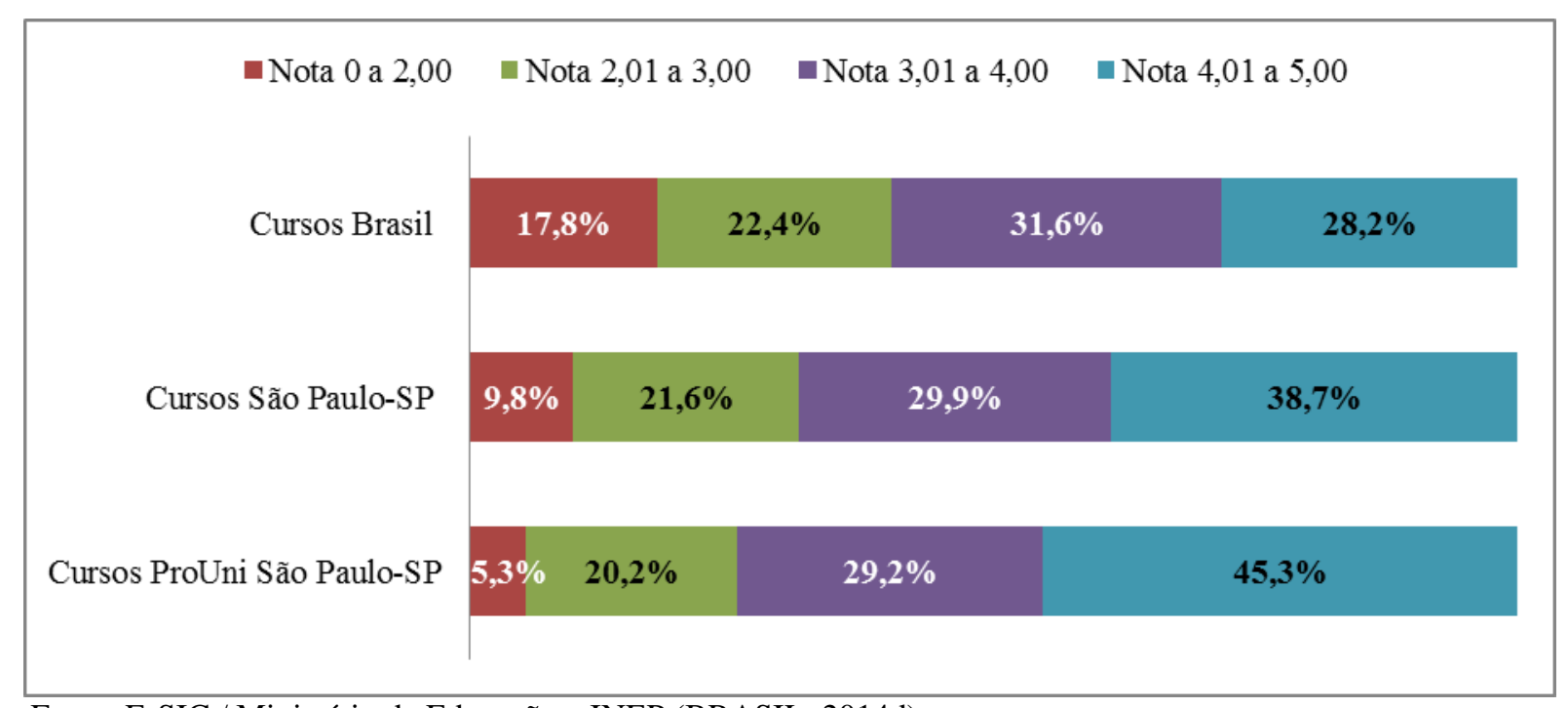

Fonte: E-SIC / Ministério da Educação e INEP (BRASIL, 2014d).

Elaboração própria.

É observado um quadro bastante positivo nos três grupos, na análise das notas padronizadas do quesito avaliado sobre a quantidade de docentes mestres nas Instituições de Ensino Superior. Ainda assim, observando o recorte dos cursos ProUni, o quadro é o mais positivo dos três grupos, em que 45,3\% das notas estão localizadas na faixa mais alta, de 4,01 a 5,00. Nos demais cursos do município, o percentual é de 38,7\%, e no Brasil, apenas 28,2\%. Na faixa de 3,01 a 4,00, os cursos ProUni lograram frequência de 29,2\%, enquanto que há maior concentração no município (29,9\%) e no Brasil (31,6\%). Já para a menor faixa, de 0 a 2,00, os cursos do ProUni apresentaram baixa frequência $(5,3 \%)$, enquanto que no município há 9,8\% de cursos na faixa, e no Brasil, 17,8\%.

$\mathrm{O}$ bom resultado pode estar relacionado à maior incidência de oferta dos cursos do ProUni selecionados em Instituições de Ensino Superior de grande porte $(47 \% \mathrm{em}$ Universidades), conforme observado anteriormente na Tabela 23 e no Gráfico 23, e o fato do grupo analisado estar restrito aos que ofereceram bolsas no município de São Paulo-SP.

Ao contrário do quesito anterior (docentes com Mestrado), não é observado um quadro positivo na análise das notas obtidas sobre a vinculação de docentes com Doutorado em todos os cursos analisados. Entretanto, mesmo diante do quadro de baixa titulação docente nesse nível, o grupo de cursos ProUni também registraram resultados superiores em relação aos demais cursos do município de São Paulo-SP e do Brasil, como é possível observar no Gráfico 25. 
Gráfico 25 - Distribuição dos cursos que ofereceram bolsas no processo seletivo do ProUni 1/2014, no município de São Paulo-SP, em relação aos demais cursos do município e do Brasil, segundo resultados do Conceito Preliminar de Curso 2012 no componente Docentes com Doutorado.

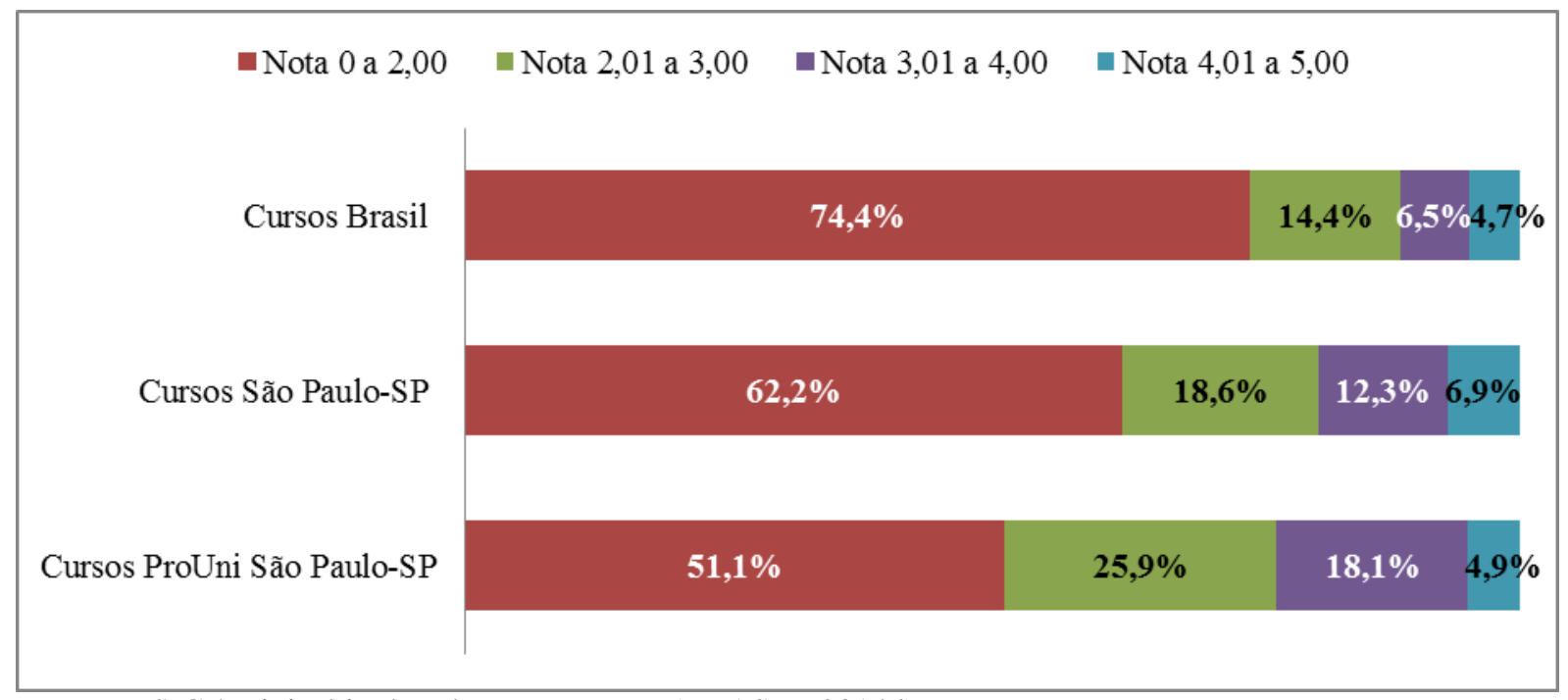

Fonte: E-SIC / Ministério da Educação e INEP (BRASIL, 2014d).

Elaboração própria.

No Gráfico 25, é possível observar que no grupo ProUni, 51,1\% das notas estão localizadas na faixa mais baixa, de 0 a 2,00; 25,9\% localizam-se na faixa de 2,01 a 3,00, 18,1\% na faixa de 3,01 a 4,00 e apenas 4,9\% na faixa superior, de 4,01 a 5,00. Em proporcionalidade, há significativo aumento da faixa mais baixa $(0$ a 2,00) nos demais cursos do município e no Brasil, com 62,2\% e 74,4\% respectivamente, e redução nas faixas de 2,01 a 3,00 (18,6\% e $14,4 \%)$ e de 3,01 a $4,00(12,3 \%$ e $6,5 \%)$.

Novamente, torna-se necessário ressaltar que o fato dos cursos ProUni selecionados concentrarem, em proporção, melhor resultado na nota sobre quantidade de docentes com Doutorado pode estar relacionado à maior incidência de oferta dos cursos do ProUni selecionados em IES de grande porte (Universidades).

Ainda em relação aos componentes referentes aos docentes dos cursos superiores que foram avaliados por meio do CPC 2012, o Gráfico 26 mostra a análise sobre a nota obtida no quesito Regime de Trabalho (integral ou parcial). Segundo o Censo da Educação Superior 2012 (a fonte das informações coletadas sobre os docentes), o regime de trabalho de um docente pode ser referente ao tempo integral com dedicação exclusiva, tempo integral sem dedicação exclusiva, tempo parcial e horista (BRASIL, 2013a). Neste caso, quanto mais alta a nota, há maior quantidade de professores vinculados ao curso trabalham na instituição em regime de trabalho integral ou parcial, e consequentemente, há menos professores em outro tipo de carga horária. 
Gráfico 26 - Distribuição dos cursos que ofereceram bolsas no processo seletivo do ProUni 1/2014 no município de São Paulo-SP, em relação aos demais cursos do município e do Brasil, segundo resultados do Conceito Preliminar de Curso 2012 no componente Regime de trabalho (integral/parcial).

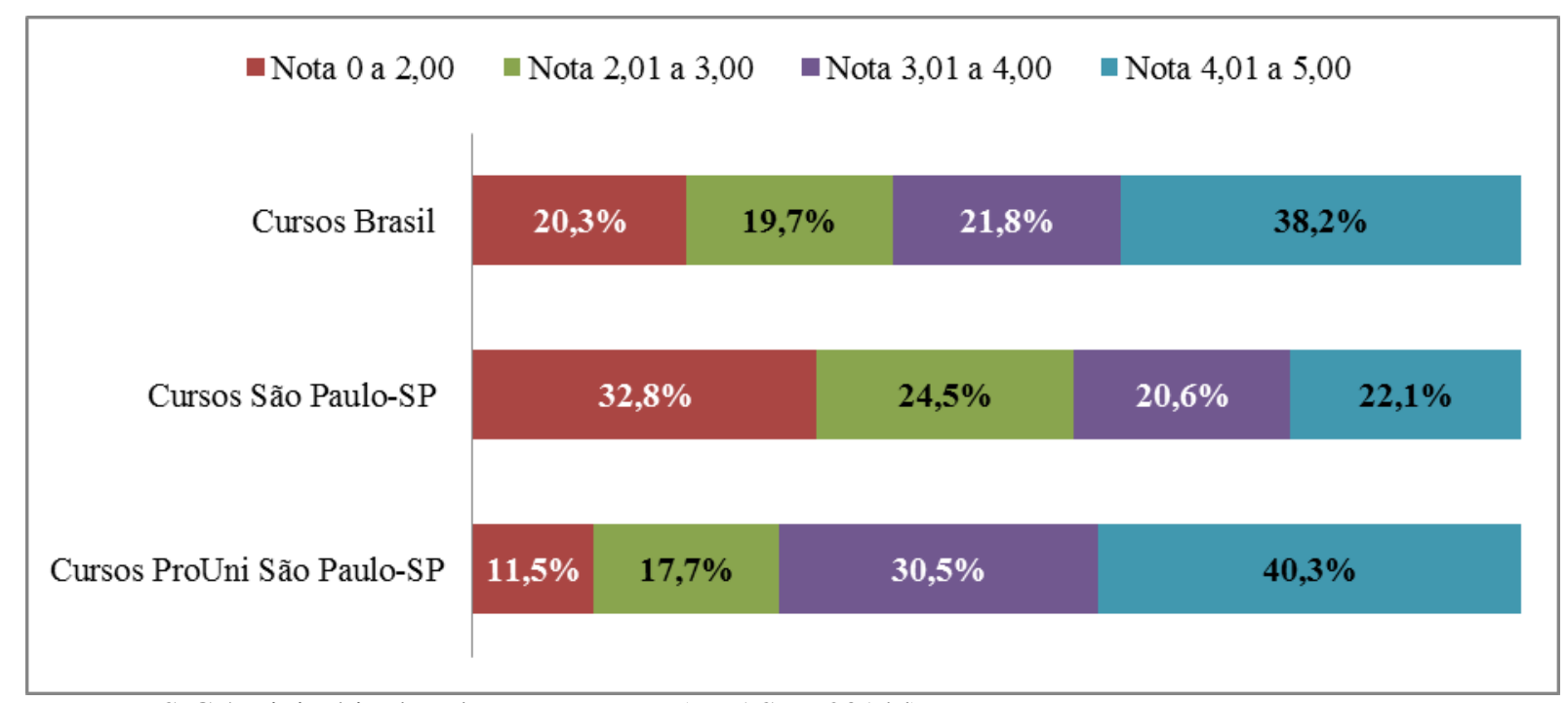

Fonte: E-SIC / Ministério da Educação e INEP (BRASIL, 2014d).

Elaboração própria.

Assim como nos quesitos anteriores relacionados ao corpo docente, os cursos ProUni selecionados obtiveram resultados superiores em relação ao regime de trabalho, apresentando maior concentração das notas nas faixas de 4,01 a 5,00 (40,3\%) e 3,01 a 4,00 (30,5\%) do que em relação aos demais cursos do município de São Paulo (22,1\% e 20,6\%, respectivamente) e aos demais cursos no Brasil (38,2\% e 21,8\%). Além disso, o grupo de cursos ProUni lograram menor frequência na faixa mais baixa ( 0 a 2,00, com 11,5\%), ou seja, a faixa que reflete a menor quantidade de professores trabalhando em regime integral ou parcial, enquanto que no município e no Brasil, a frequência foi de $32,8 \%$ e $20,3 \%$, respectivamente.

Prosseguindo a análise por meio das variáveis componentes do $\mathrm{CPC}$, a seguir é apresentado um desdobramento dos dados a respeito das notas padronizadas obtidas pelos cursos analisados, nos quesitos Formação Geral e Componente Específico, variáveis atreladas ao resultado do desempenho dos estudantes concluintes no ENADE. O Exame é composto de 40 questões, sendo dividido em duas partes (10 questões para a parte de Formação Geral e 30 questões para a parte de Formação Específica da área em questão). As duas partes possuem questões discursivas e de múltipla escolha (BRASIL, 2015b). 
Gráfico 27 - Distribuição dos cursos que ofereceram bolsas no processo seletivo do ProUni 1/2014, no município de São Paulo-SP, em relação aos demais cursos do município e do Brasil, segundo resultados do Conceito Preliminar de Curso 2012 no componente Formação Geral.

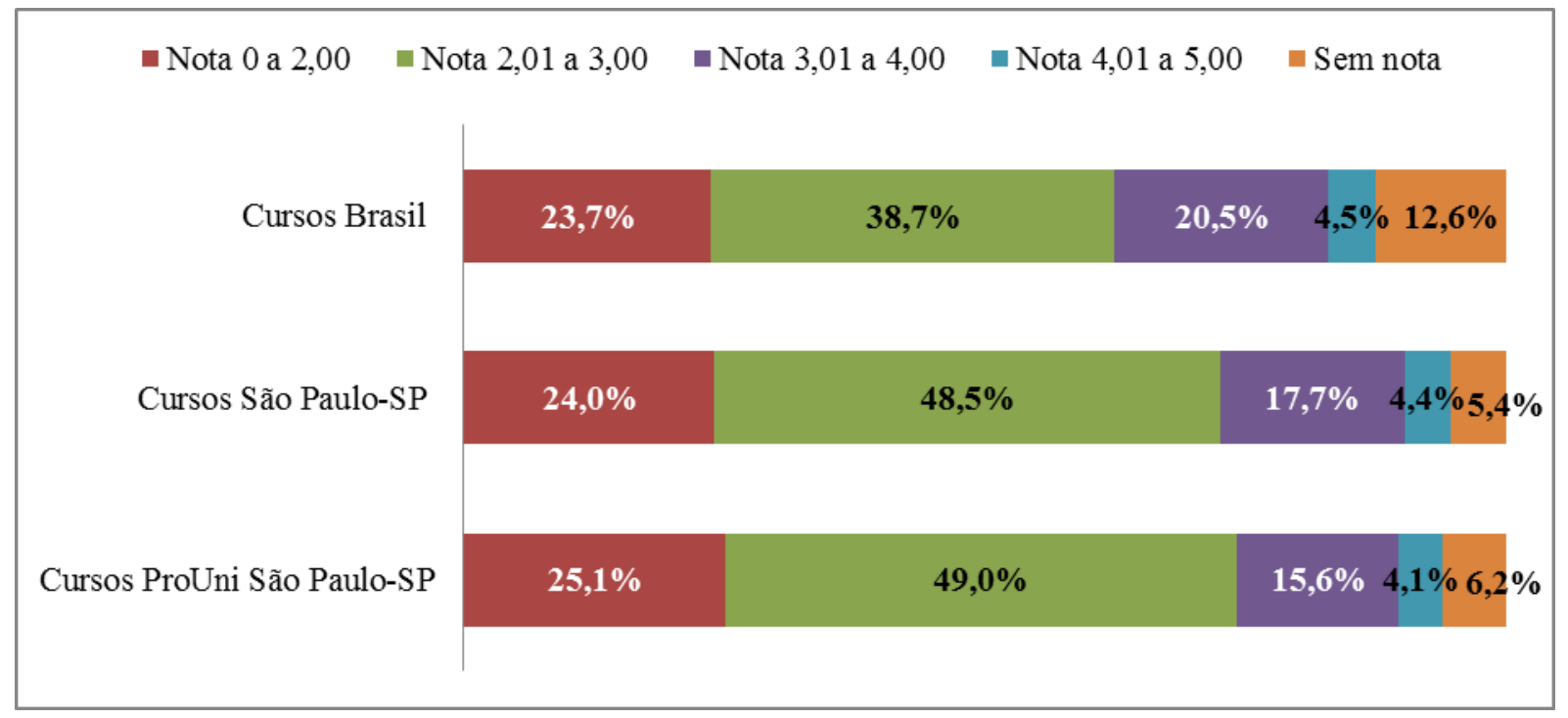

Fonte: E-SIC / Ministério da Educação e INEP (BRASIL, 2014d).

Elaboração própria.

Quando foi analisado o insumo do CPC que corresponde às notas padronizadas de Formação Geral, relativas ao desempenho dos estudantes concluintes dos cursos selecionados, é possível observar que os cursos do ProUni estão distribuídos em: 49\% na faixa de nota de 2,01 a 3,00; outros $25,1 \%$ estão na faixa de 0 a 2,00, e 15,6\% estão na faixa de 3,01 a 4,00. Apenas 4,1\% dos cursos localizam-se na faixa superior, de 4,01 a 5,00, e 6,2\% ficaram sem nota.

Realizando a comparação com os demais cursos de São Paulo-SP e do Brasil, é observado um quadro levemente inferior, mas muito semelhante dos ProUni em relação ao município; e um resultado também inferior em relação aos resultados obtidos nos cursos do Brasil, que lograram uma frequência de $38,7 \%$ na faixa de 2,01 a 3,00, de 23,7\% na faixa de 0 a 2,00 e 20,5\% na faixa de 3,01 a 4,00. Apenas entre os cursos da faixa sem nota é que o grupo dos cursos ProUni menor número de cursos (6,2\% contra 12,6\% nos demais cursos do Brasil). 
Gráfico 28 - Distribuição dos cursos que ofereceram bolsas no processo seletivo do ProUni 1/2014, no município de São Paulo-SP, em relação aos demais cursos do município e do Brasil, segundo resultados do Conceito Preliminar de Curso 2012 no quesito Componente Específico.

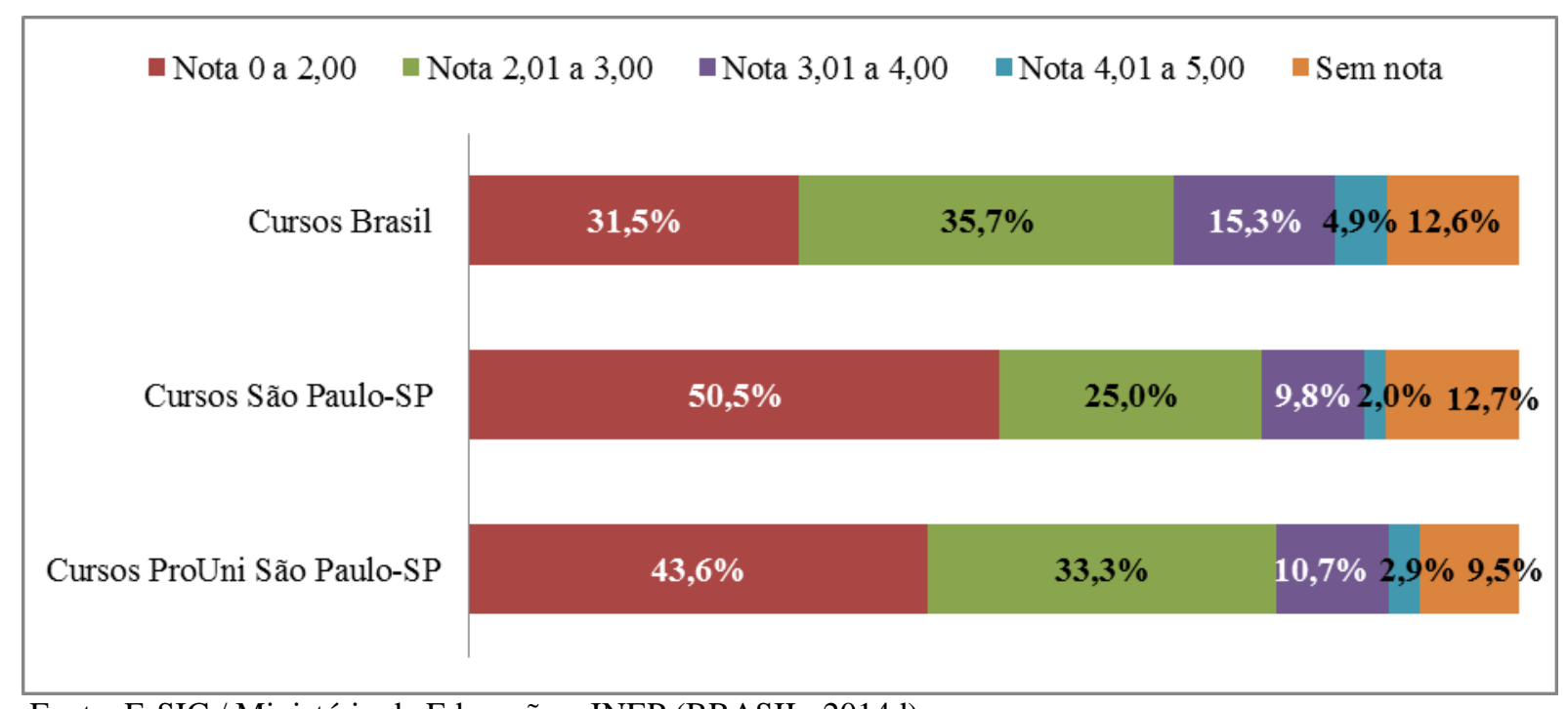

Fonte: E-SIC / Ministério da Educação e INEP (BRASIL, 2014d).

Elaboração própria.

Quando foi analisado o insumo do CPC relativo às notas padronizadas do Componente Específico (Gráfico 28), que se refere ao desempenho dos estudantes concluintes em áreas diretamente ligadas aos cursos avaliados, é possível observar que os cursos ProUni selecionados foram distribuídos em: 43,6\% na faixa das menores notas, de 0 a 2,00; outros 33,3\% estão localizados na faixa de 2,01 a 3,00, e 10,7\% estão na faixa de 3,01 a 4,00. Apenas 2,9\% dos cursos localizam-se na faixa superior, de 4,01 a 5,00, e 9,5\% ficaram sem nota no quesito.

Realizando a comparação com os demais cursos de São Paulo-SP e do Brasil, foi identificado um quadro de melhor desempenho obtido pelos estudantes dos cursos ProUni selecionados, em relação ao município (que possui 50,5\% das notas na faixa de 0 a 2,00 e $25 \%$ na faixa de 2,01 a 3,00), e um pior desempenho em relação aos resultados obtidos nos cursos do Brasil, que lograram uma frequência de $35,7 \%$ na faixa de 2,01 a 3,00, de 31,5\% na faixa de 0 a 2,00, 15,3\% na faixa de 3,01 a 4,00 e 4,9\% na faixa superior, de 4,01 a 5,00.

Uma questão bastante relevante a ser destacada é que, com relação à análise anterior, da frequência das notas do quesito Formação Geral (Gráfico 27), os resultados no quesito Componente Específico lograram pior desempenho em todos os grupos de cursos analisados. Ou seja, os resultados de desempenho dos estudantes concluintes foram piores nas provas que versam sobre questões exclusivas das áreas que cursam.

O Indicador de Diferença entre os Desempenhos Observado e Esperado (IDD), conforme mencionado no início deste Capítulo, remete à uma ampla gama de cálculos, que 
possuem variáveis ligadas ao desempenho dos estudantes no ENEM, ENADE e em respostas aos Questionários do Estudante do ENEM e do ENADE, visando uma mensuração das diferenças em relação ao perfil dos estudantes ao ingressar e ao concluir o ensino superior. No Gráfico 29, é apresentado o resultado dos grupos de cursos observados em relação a essa variável.

Gráfico 29 - Distribuição dos cursos que ofereceram bolsas no processo seletivo do ProUni 1/2014, no município de São Paulo-SP, em relação aos demais cursos do município e do Brasil, segundo resultados do Conceito Preliminar de Curso 2012 no componente Indicador de Diferença entre os Desempenhos Observado e Esperado.

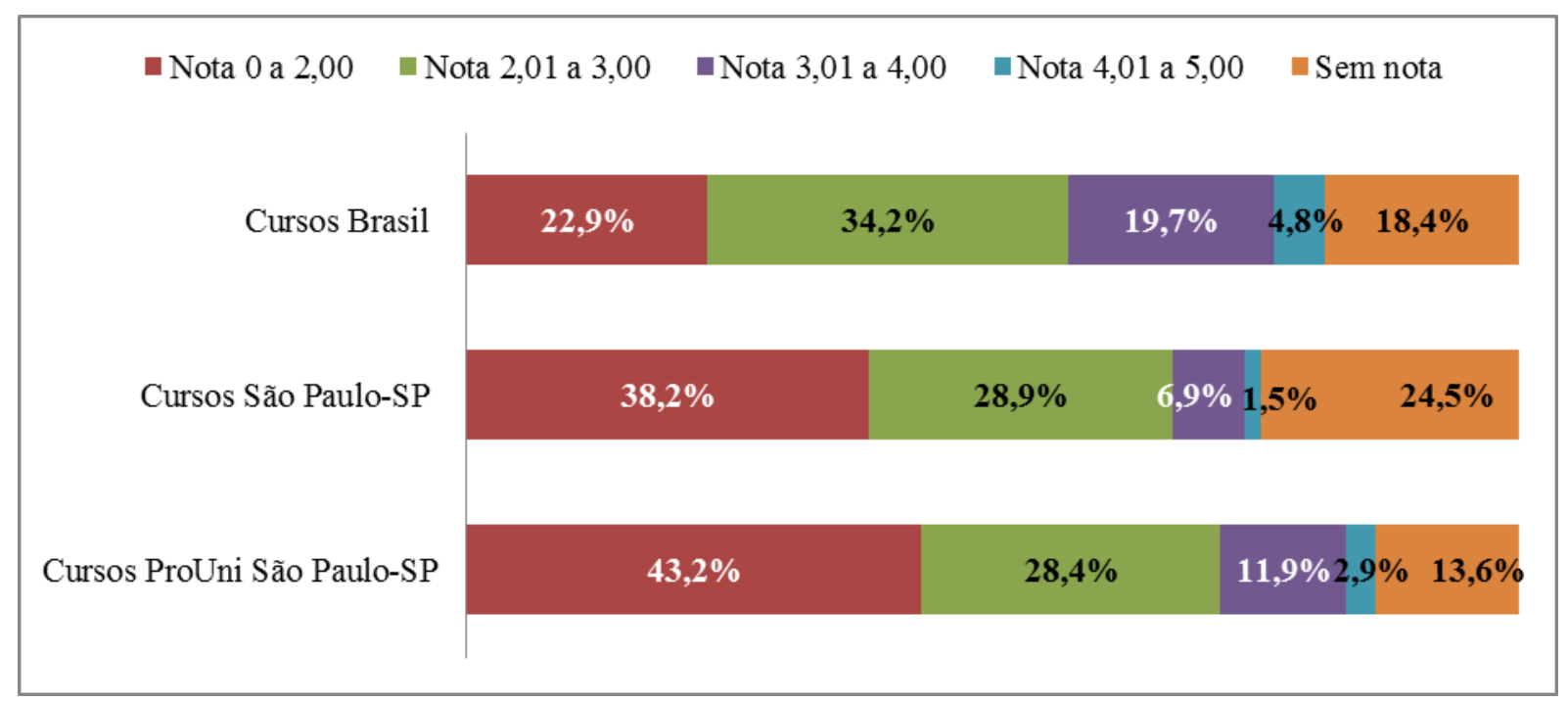

Fonte: E-SIC / Ministério da Educação e INEP (BRASIL, 2014d).

Elaboração própria.

Os dados mostram que, no caso do componente IDD, o melhor resultado observado está concentrado nos cursos do Brasil, que apresentam frequência de 22,9\% na faixa de 0 a 2,00; $34,2 \%$ na faixa de 2,01 a 3,00; $19,7 \%$ na faixa de 3,01 a 4,00 e 4,8\% na faixa mais alta, 4,01 a 5,00. Nesse sentido, os cursos do ProUni analisados estão aquém desse resultado, pois há muito mais frequência de cursos, proporcionalmente, na faixa de 0 a 2,00 (43,2\%), e menor frequência na faixas de 2,01 a 3,00 (28,4\%) e 4,01 a 5,00 (11,9\%). O resultado observado é semelhante ao registrado nos demais cursos do município de São Paulo-SP, exceto na quantidade de cursos sem nota, que é maior no município (24,5\% contra 13,6\%).

Entre os resultados obtidos na avaliação sobre a Infraestrutura das Instituições de Ensino Superior que ofertaram os cursos (que, segundo a metodologia divulgada, são calculados após serem obtidos por meio das respostas dos estudantes ao Questionário do ENADE, acerca da disponibilidade de equipamentos e materiais para as aulas - ou seja, quanto maior a nota obtida, 
melhor foi a avaliação foi dada pelos discentes em relação aos equipamentos e/ou materiais disponíveis nos ambientes para aulas práticas, relacionados ao curso), a análise do Gráfico 30 indica que os cursos ProUni selecionados obtiveram resultado levemente superior no aglomerado das faixas mais altas das notas padronizadas (que somam 70,3\% de 3,01 a 5,00), em relação aos cursos do município (64,2\%) e do Brasil (67,8\%). Os cursos ProUni também observaram resultado inferior nas notas mais baixas (16,5\%, contra 19,6\% do município e $21,1 \%$ do Brasil).

Gráfico 30 - Distribuição dos cursos que ofereceram bolsas no processo seletivo do ProUni 1/2014, no município de São Paulo-SP, em relação aos demais cursos do município e do Brasil, segundo resultados do Conceito Preliminar de Curso 2012 no componente Infraestrutura.

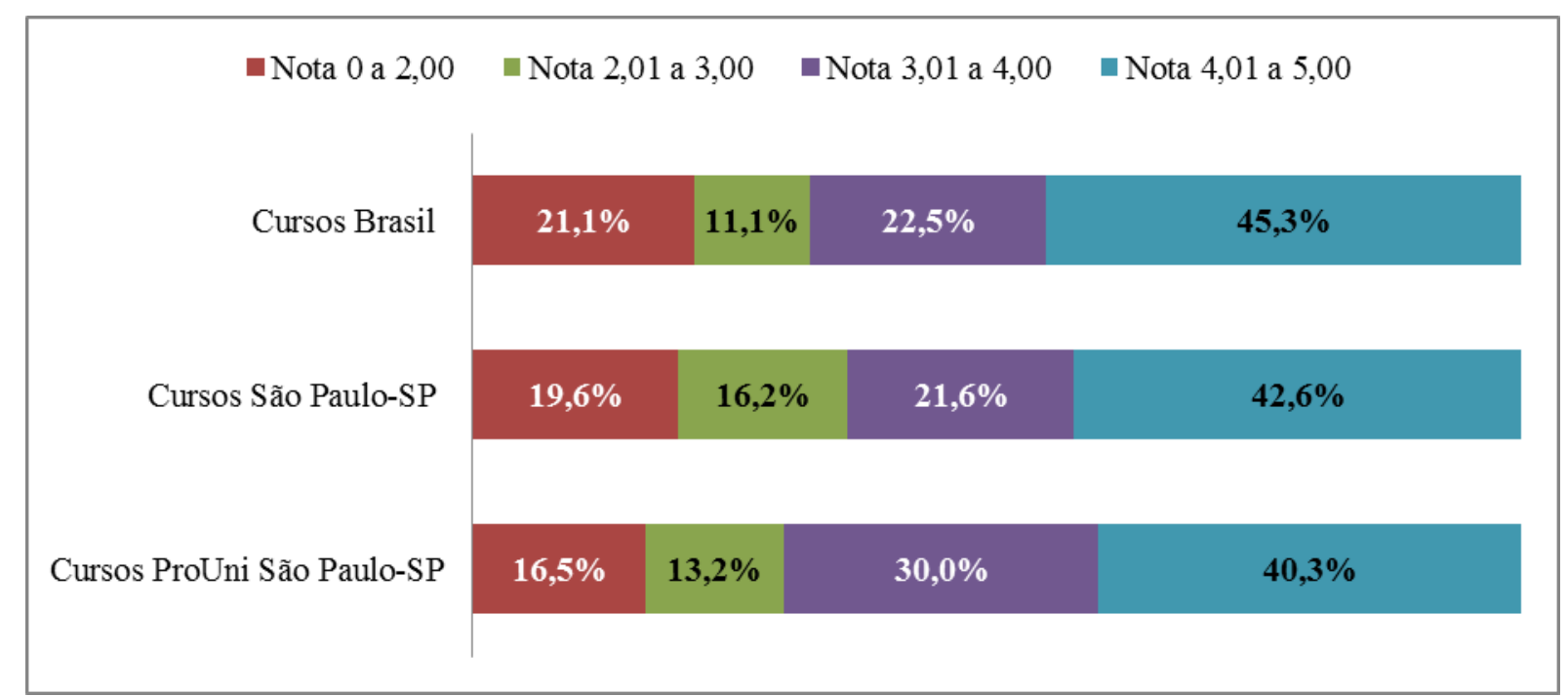

Fonte: E-SIC / Ministério da Educação e INEP (BRASIL, 2014d).

Elaboração própria.

O último insumo do Conceito Preliminar de Curso 2012 selecionado para a análise é o quesito Organização Didático-Pedagógica (cujos resultados também foram calculados a partir das respostas discentes ao Questionário do Estudante do ENADE). Ou seja, quanto maior a nota obtida, melhor foi a avaliação foi dada pelos discentes em relação aos aspectos do plano de ensino apresentados pelos professores, relacionados ao curso. O Gráfico 31 mostra que os cursos ProUni selecionados obtiveram resultados levemente superiores nas faixas de 2,01 a 3,00 , com 32,5\% e 3,01 a 4,00, com 26,4\%. Por outro lado, apresentaram menor frequência na faixa superior, de 4,01 a 5,00, com 11,5\% (contra 15,2\% em São Paulo-SP e 20,4\% nos demais cursos do Brasil). 
Gráfico 31 - Distribuição dos cursos que ofereceram bolsas no processo seletivo do ProUni 1/2014, no município de São Paulo-SP, em relação aos demais cursos do município e do Brasil, segundo resultados do Conceito Preliminar de Curso 2012 no componente Organização Didático-Pedagógica.

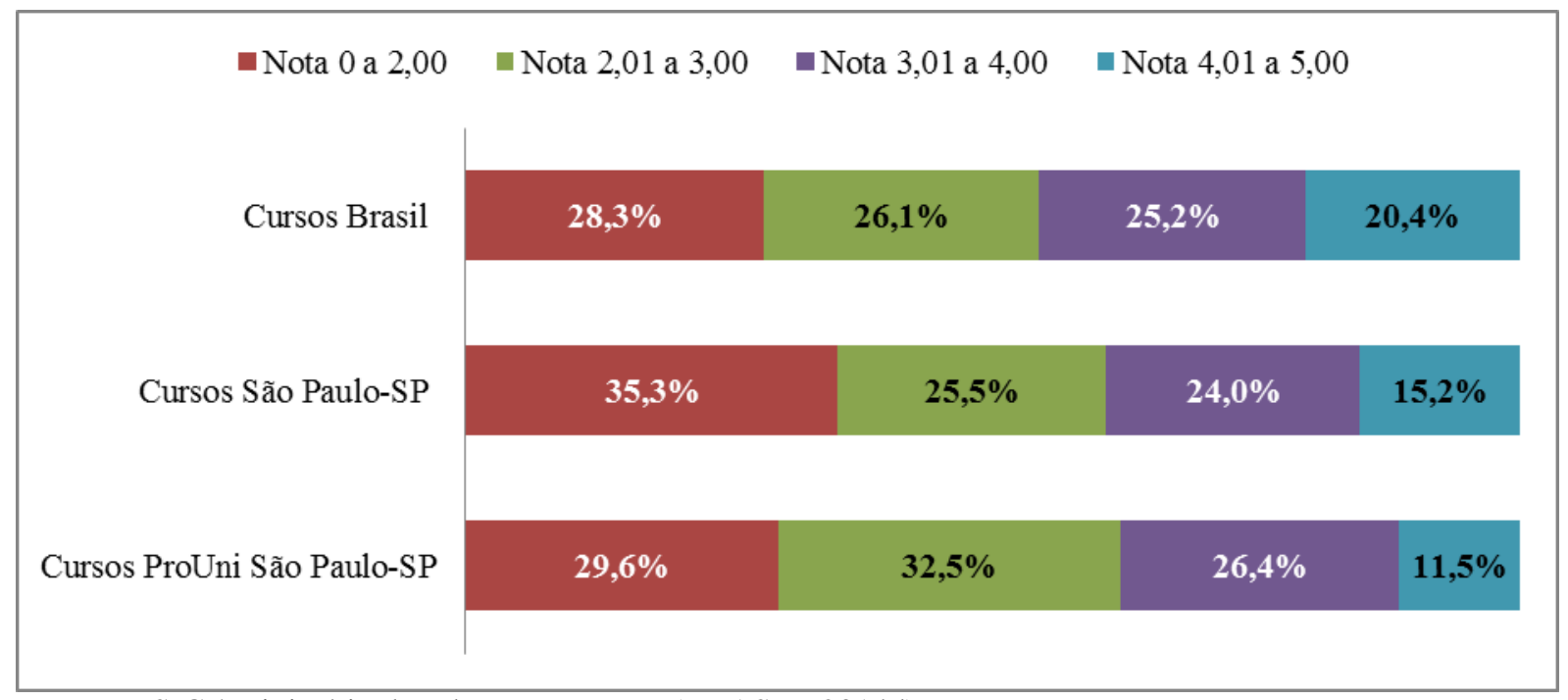

Fonte: E-SIC / Ministério da Educação e INEP (BRASIL, 2014d).

Elaboração própria.

Da análise dos resultados dos dois quesitos (Infraestrutura e Organização DidáticoPedagógica), aparece como relevante a questão que, em todos os grupos de cursos, as avaliações discentes foram bastante positivas no primeiro quesito (concentrando-se na faixa de notas de 4,01 a 5,00), mas não tanto no segundo (com distribuição mais homogênea entre as diversas faixas). No tocante aos cursos do ProUni, foi observada a mesma tendência, de melhor avaliação nos quesitos de Infraestrutura.

Entretanto, conforme a discussão realizada no início deste Capítulo sobre a composição do CPC, não há consenso na literatura sobre a questão da avaliação desses quesitos ser realizada diretamente e primeiramente pelos alunos dos cursos, via Questionário do Estudante do ENADE, sendo alvo de críticas por parte de autores como Rothen e Barreyro (2011).

A seguir, são apresentadas as Considerações Finais da dissertação, nas quais são discutidos os resultados atingidos a partir da pesquisa contida neste Capítulo, considerando a discussão mais ampla sobre educação superior, avaliação e qualidade no contexto do Programa Universidade para Todos (ProUni). 


\section{CONSIDERAÇÕES FINAIS}

O objetivo geral desta pesquisa foi discutir a questão da qualidade dos cursos que ofertaram bolsas pelo ProUni, a partir dos resultados de avaliação de cursos do SINAES, mais espeficiamente os resultados do Conceito Preliminar de Curso (CPC). Para subsidiar a análise dos resultados, foi realizada primeiramente nesta dissertação uma discussão sobre os principais temas relacionados ao objetivo proposto.

No Capítulo 1, foi apresentada a trajetória da educação superior no Brasil e as políticas de avaliação, em especial o SINAES, além da discussão conceitual sobre qualidade da educação superior, inserida neste contexto.

No Capítulo 2, foi apresentado o debate sobre o ProUni, entre a criação da política, seu funcionamento e a literatura relacionada ao tema. Por meio da exploração de novos dados sobre o ProUni, foi possível apresentar algumas estatísticas dos processos seletivos de 2013 e 2014 sobre: número de bolsas, tipo de bolsa, os cursos e IES que as ofertaram, regionalização (por UF e município), turnos, etc. Os dados suscitaram questões interessantes, como a alta concentração do oferecimento de bolsas em poucas IES participantes do Programa, muitas vezes pertencentes a grandes grupos educacionais; em relação às regiões geográficas, a oferta se dá predominantemente no Sudeste; e em relação aos cursos, as bolsas ofertadas estão visivelmente concentradas na área de Ciências Humanas (Administração, Direito e Pedagogia), ou seja, uma área caracterizada pelo baixo investimento. Esse quadro reflete um patamar muito semelhante ao do identificado na educação superior brasileira privada em geral.

No Capítulo 3, foi realizada uma discussão sobre o Conceito Preliminar de Curso enquanto indicador de qualidade dos cursos superiores brasileiros, observada a revisão bibliográfica sobre o tema. Também se problematizou o processo de avaliação dos cursos que ofertam bolsas pelo ProUni, questionando quais os critérios empregados na legislação concernente ao Programa. Por fim, para concretizar o objetivo geral proposto por esta pequisa, foram analisados dados sobre os cursos participantes do ProUni no processo seletivo do primeiro semestre de 2014, em relação aos resultados do CPC 2012. Os dados sobre os cursos do ProUni foram desagregados por tipo de bolsa ofertada (parcial ou integral), grau acadêmico (Bacharelado ou Curso Superior de Tecnologia), áreas de enquadramento, entre outras variáveis.

O grupo de cursos escolhido (243) correspondeu a 46,4\% do total (911) de cursos que ofertaram bolsas no processo seletivo do ProUni do primeiro semestre de 2014 referente ao 
local de oferta do município de São Paulo-SP, e também reuniu a oferta de 9.786 bolsas, um total de $36,4 \%$ em relação ao total (26.841) da oferta de bolsas pelo ProUni no mesmo período e município.

É importante ponderar que o grupo de cursos selecionado para a análise possui limitações, em termos quantitativos, temporais e até mesmo regionais. Portanto, não se pretende realizar a generalização dos resultados apresentados para o universo de cursos que ofertam bolsas pelo ProUni. Destaca-se aqui o caráter exploratório deste trabalho e a necessidade de aprofundamento da temática em pesquisas posteriores, em que mais estudos seriam necessários para que identificar se os resultados aqui apresentados podem constituir uma tendência, ou se passam por mudanças, dependendo da influência de outras variáveis. Todavia, o objetivo da pesquisa foi de explorar novos dados sobre o Programa Universidade para Todos. Sendo a qualidade dos cursos ProUni um ponto bastante questionado na literatura sobre o tema, pois ainda há muitos entraves para se mensurar a qualidade (e outros aspectos) desses cursos, bem como das próprias instituições que os ofertam, os resultados apresentados neste trabalho podem auxiliar a suscitar novos questionamentos acerca dessa política de educação superior.

Em síntese, transcorrida a análise dos dados apresentados no Capítulo 3, pode-se dizer que, no caso dos 243 cursos ProUni selecionados para análise, que ofertaram bolsas em São Paulo-SP no primeiro semestre de 2014, nem sempre apresentam-se resultados ligados à baixa qualidade (ou, conforme denominação oficial no âmbito do SINAES, resultados insatisfatórios), como poderia-se pensar, de antemão, acerca dos cursos cujas bolsas são ofertadas no Programa - sempre ressaltando que foi utilizado o CPC enquanto indicador de qualidade oficial. Em muitos casos, esse grupo de cursos acompanhou a tendência de distribuição observada nos outros grupos (demais cursos do município de São Paulo-SP e Brasil, avaliados pelo CPC), e em alguns casos, até mesmo apresentaram resultados melhores do que os demais grupos de cursos. Por outro lado, a correspondência com os critérios de qualidade mostrou-se desigual quando se considerou na análise variáveis como o grau acadêmico, o tipo de bolsa ofertada e a área de enquadramento em que o curso está relacionado, conforme será recapitulado a seguir.

Analisando somente os cursos ProUni, foi verificada concentração predominante na faixa $3(53,5 \%)$, ou seja, o mínimo satisfatório do CPC; entretanto, há menos cursos na faixa do Conceito $4(14,8 \%)$ e um número muito diminuto de cursos na faixa $5(1,2 \%)$. Uma outra parcela dos cursos estão na faixa 2 do CPC $(11,9 \%)$, considerada insatisfatória segundo os parâmetros do SINAES. Também entre estes cursos que ofertaram bolsas pelo ProUni, existem 
cursos Sem Conceito $(6,2 \%)$ e com status de ausência de reconhecimento $(12,4 \%)$, o que pode trazer incertezas sobre a qualidade (nos parâmetros da avaliação oficial) dos mesmos.

Com relação à desigualdade apresentada na correspondência aos critérios de qualidade, quando foram desagregados os cursos por variáveis como tipo de bolsa ofertada, grau acadêmico e área de enquadramento do curso, verificou-se que no tipo de bolsa (integral ou parcial), as bolsas parciais concentraram-se em cursos que obtiveram resultado visivelmente pior em relação ao indicador do CPC, se compararmos com a distribuição observada no caso das bolsas integrais.

Na desagregação dos cursos ProUni por grau acadêmico, percebeu-se que os Cursos Superiores de Tecnologia apresentaram pior resultado nos indicadores de qualidade do CPC em relação aos cursos de Bacharelado. O número elevado de cursos ProUni com CPC 2, considerado insatisfatório, e também Sem Conceito e/ou sem reconhecimento na época da avaliação, está presente de forma mais clara entre os Cursos Superiores de Tecnologia do que nos de Bacharelado. A partir dessa análise, seria importante observar se, historicamente, os CSTs possuem maior oferta nos processos seletivos do ProUni. Entretanto, não há séries estatísticas oficiais a esse respeito. Conforme os dados obtidos e apresentados no Capítulo 2, os cursos de Bacharelado foram maioria (15 entre os 20 que mais ofertaram bolsas ${ }^{85}$ ) no processo seletivo do primeiro semestre de 2014 .

Quando os cursos foram analisados por área de enquadramento, foi verificado que entre os Bacharelados, na faixa 4 do CPC, ocorreu maior concentração de cursos de Psicologia e Ciências Contábeis. Somente três áreas de enquadramento registraram cursos na faixa 5 do CPC (Relações Internacionais, Ciências Contábeis e Administração). Já entre os Tecnólogos, existem poucos cursos na faixa do CPC 4, e na faixa do CPC 5 não foi registrado nenhum Curso Superior de Tecnologia dentre os selecionados.

Quando foram realizadas comparações em nível geográfico, ou seja, entre os resultados dos 243 cursos do ProUni selecionados, em relação aos resultados obtidos dos grupos dos demais cursos do município de São Paulo - SP (204) e do Brasil (6.834) que foram avaliados pelo CPC 2012, identificou-se que a distribuição pelas faixas do indicador possui tendência semelhante entre os cursos do ProUni e os demais cursos de São Paulo - SP.

\footnotetext{
${ }^{85}$ Os cinco CSTs que apareceram entre os 20 cursos que ofertaram mais bolsas no processo seletivo selecionado foram: Gestão de Recursos Humanos (2,8\%), Marketing (2,6\%), Redes de Computadores (1,7\%), Logística $(1,7 \%)$ e Tecnologia da Informação $(1,6 \%)$. Os outros cursos, que são de Bacharelado, estão visivelmente concentrados na área de Ciências Humanas - especialmente Administração (8,5\%), Direito (7,2\%) e Pedagogia $(5,6 \%)$.
} 
Entretanto, nota-se que, em proporção, os cursos identificados como ProUni alcançaram resultados melhores nas faixas 2, 4 e 5, do que o observado no quadro dos demais cursos de São Paulo - SP. Além disso, na faixa Sem Conceito identifica-se, na análise, uma proporção muito menor de cursos do ProUni do que os cursos ofertados em São Paulo - SP. Ou seja, pelos dados apresentados, é possível afirmar que os cursos ProUni analisados possuem qualidade semelhante em relação aos demais cursos do município, inclusive alcançando resultados melhores nas faixas mais altas do CPC.

Em relação aos demais cursos ofertados em todo o Brasil, por outro lado, observaramse melhores resultados em relação ao CPC no grupo de cursos do Brasil, do que nos cursos identificados como ProUni, e até mesmo dos demais cursos de São Paulo-SP; em proporcionalidade, foi identificado que no Brasil há menos cursos CPC 2, e mais cursos CPC 4 e CPC 5 do que nos outros grupos. Contudo, um aspecto positivo é que foi registrado menor número de cursos ProUni nas faixas Sem Conceito e de unidades sem reconhecimento, do que o restante dos cursos do Brasil.

Da análise entre os cursos ProUni, os demais cursos de São Paulo-SP e do Brasil, segmentados por área de enquadramento (Administração, Ciências Contábeis, Direito, Logística e Gestão de Recursos Humanos), foi possível destacar o aspecto preocupante em que há ausência, ou presença extremamente diminuta, de cursos com CPC 5 em todos os grupos de cursos, sendo esse o CPC considerado como o que possui maior correspondência com os critérios de qualidade exigidos.

Em síntese, diante desses resultados, pode-se inferir que os cursos ProUni selecionados para a análise acompanham a tendência de resultados de avaliação registrados nos demais cursos do município e do país, ou seja, não destoam do quadro de resultados gerados para a totalidade da educação superior brasileira. E, ainda assim, foram registrados resultados superiores destes em relação ao critério de qualidade estabelecido, em alguns casos, como em relação aos demais cursos de São Paulo-SP.

Desagregando os dados em torno dos resultados de alguns dos componentes do CPC, um dos destaques da análise refere-se aos resultados positivos obtidos pelos cursos ProUni analisados, em relação às variáveis do $\mathrm{CPC}$ relativas ao corpo docente: quantidade de docentes com Mestrado, docentes com Doutorado e se o Regime de Trabalho desses profissionais é integral ou parcial. Segundo trecho do Resumo Técnico do Censo da Educação Superior 2012 do INEP, 
Cumpre destacar que um dos parâmetros de cálculo do Conceito Preliminar de Curso (CPC) é o grau de formação dos docentes coletado no Censo da Educação Superior. A melhoria do CPC para a IES está relacionada com o aumento do nível de titulação dos professores vinculados aos cursos, com vistas à melhoria da qualidade da oferta (BRASIL, 2013c, p. 74)

Entre a quantidade de docentes com Mestrado, o recorte dos cursos ProUni selecionados registrou o quadro mais positivo entre os três grupos de cursos analisados, em que ocorreu maior concentração das notas na faixa mais alta das notas padronizadas, de 4,01 a 5,00. No quesito docentes com Doutorado, mesmo diante de um quadro crítico (no total dos cursos avaliados no Brasil, há baixo índice de professores com esse nível de titulação), o grupo de cursos ProUni também registrou resultados superiores em relação aos demais cursos do município de São Paulo-SP e do Brasil. Os cursos ProUni selecionados também obtiveram resultados superiores em relação ao regime de trabalho integral ou parcial, apresentando maior concentração das notas nas faixas mais altas $(3,01$ a 5,00) do que em relação aos demais cursos do município de São Paulo e aos outros cursos no Brasil.

Essa situação pode estar relacionada à constatação de que houve maior incidência de oferta dos cursos do ProUni selecionados em Instituições de Ensino Superior de grande porte (47\% em Universidades, enquanto que, no cursos do município e no país, há predominância de oferta de cursos em Faculdades, entre 51\% e 55\%). No entanto, é importante ponderar o fato de o grupo ProUni analisado estar restrito aos que ofereceram bolsas no local de oferta do município de São Paulo-SP, em que já encontra-se um quadro de maior concentração de cursos ofertados em IES maiores (Universidades e Centros Universitários) ligados a grandes grupos educacionais - segmento que possui maior aderência ao ProUni. No Capítulo 2, foi mencionado que a maior oferta de vagas, por parte das IES de grande porte, gera um processo de fortalecimento dessas instituições, por conta das isenções fiscais que o Programa concede (CARVALHO, 2006, 2011a). Além disso, embora tenham sido registrados indicadores positivos em relação ao corpo docente dos cursos, esse quadro de concentração pode sinalizar uma situação de pouca diversificação institucional, e consequentemente, do modelo de ensino ofertado pelos cursos que participam do ProUni.

Nos quesitos referentes ao desempenho dos estudantes no ENADE, que também compõem o cálculo do CPC, na parte de Formação Geral, realizando a comparação com os demais cursos de São Paulo-SP e do Brasil, observa-se um quadro levemente inferior, mas muito semelhante dos ProUni em relação ao município; e um resultado também inferior em relação aos resultados obtidos nos cursos do Brasil. Já na parte do Componente Específico, 
voltado à questões relativas aos conteúdos dos cursos dos alunos, foi exibido um quadro de melhor desempenho obtido pelos estudantes dos cursos ProUni selecionados, em relação ao município, e um pior desempenho em relação aos resultados obtidos nos cursos do Brasil.

Nesse sentido, apontados os principais resultados da pesquisa, cujo objetivo principal foi analisar a questão da qualidade dos cursos que ofertaram bolsas pelo ProUni, considerou-se importante, também, realizar uma reflexão sobre os critérios de qualidade exigidos e em vigor no ProUni. Diante da análise, emergiu o questionamento se a avaliação dos cursos participantes do ProUni consegue realizar-se efetivamente e assegurar um padrão mínimo de qualidade aos cursos.

A legislação referente ao Programa assinala que é preciso ocorrer, atualmente, duas avaliações consecutivas com resultado insuficiente, segundo critérios estabelecidos no SINAES, para que um curso seja desvinculado do Programa. Conforme observado no Capítulo 3, além da legislação da política não ser explícita a respeito de qual indicador é utilizado para a avaliação desses cursos, também utiliza-se o termo insuficiente - o que não consta na Lei do SINAES e na legislação correlata, em que é utilizado o termo insatisfatório. De todo modo, considerando que muitos cursos obtiveram CPC insatisfatório em 2012, ou sequer foram avaliados, e na prática ofertaram bolsas ProUni no determinado processo seletivo, questiona-se sobre a formação acadêmica dos beneficiários do ProUni, que pode estar comprometida em relação à qualidade ofertada, considerando os parâmetros oficiais de avaliação de cursos.

Tal problematização se faz relevante, se pensarmos em que medida a avaliação da educação superior brasileira, via SINAES, interliga-se com a avaliação dos cursos que ofertaram bolsas pelo ProUni. Um curso deve ser considerado insuficiente por duas avaliações consecutivas para ser descredenciado do ProUni; embora o CPC seja divulgado anualmente, as avaliações de cada área de enquadramento no SINAES, conforme mencionado no Capítulo 1, possuem periodicidade trienal - o que, de certa forma, limita a quantidade de cursos a serem avaliados anualmente. Destaca-se que somente alguns cursos foram avaliados no ano de 2012, concentrados nas áreas de Ciências sociais aplicadas, Ciências humanas e áreas afins, além de eixos Tecnológicos de Gestão e Negócios, Apoio Escolar, Hospitalidade e Lazer, Produção Cultural e Design. Essas mesmas áreas de 2012, segundo o calendário de avaliação do ENADE, foram avaliadas no ano de 2009, e novamente somente em 2015. Ao que tudo indica (apesar da legislação não ser clara a este respeito), as duas avaliações do ProUni seriam o fechamento de duas avaliações trienais do SINAES (BRASIL, 2009a, p. 64). Acrescenta-se a esses fatores, a 
conclusão relatada pelo Tribunal de Contas da União, durante a auditoria realizada em 2009 sobre o ProUni e o Fies, em que:

[...] os instrumentos de avaliação de cursos superiores e Instituições de Ensino Superior existentes não têm sido eficazes no que se refere ao papel de evitar a permanência de alunos participantes dos programas ProUni e Fies em cursos mal avaliados. Primeiro, porque 34,6\% desses cursos no ProUni e $18 \%$ no Fies nunca foram avaliados, mesmo já tendo sido fechado um ciclo de avaliação do Enade (BRASIL, 2009a, p. 66)

Diante do quadro observado, tal processo revela um descompasso entre os cursos oferecidos e o período de avaliação dos mesmos, segundo a legislação oficial do Programa. Esse processo pode dificultar, ainda mais, o controle da qualidade dos cursos que ofertam bolsas pelo ProUni, e consequentemente, o desvinculamento de cursos considerados insatisfatórios (ou insuficientes?) em relação aos critérios de qualidade. Nesse sentido, questiona-se: a atual forma de vinculação entre a avaliação de cursos de graduação, que é realizada pelo SINAES, e os propósitos de avaliação que vigoram no ProUni são realmente suficientes, ou poderiam ser aperfeiçoados, a fim de estabelecer maior rigor para os cursos que futuramente oferecerão bolsas pelo Programa.

Por outro lado, ainda que a dimensão da avaliação seja relevante para obter um panorama geral da situação dos cursos participantes do ProUni, o sistema de avaliação brasileiro, por intermédio do SINAES, ainda passa por diversas transformações em sua operacionalização ${ }^{86}$, o que conduz a outro ponto importante a ser discutido: a dificuldade de regulação e controle da educação ofertada pela iniciativa privada em franco processo de expansão, oligopolização e financeirização, conforme já mencionado anteriormente na análise das IES que oferecem estes cursos.

O ProUni, sendo uma política que se relaciona unicamente com o setor privado de educação superior, acaba refletindo as problemáticas inerentes a essa esfera, com relação à expansão, concentração e diversificação institucional, financiamento, privatização, oligopolização, precarização de condições de trabalho, etc. Tal como no debate realizado de forma mais extensa no Capítulo 2, para alguns autores, inclusive, o ProUni fortaleceu estes processos (LEHER, 2004; CARVALHO, 2006, 2011a). Nesse sentido, de acordo com Sguissardi (2008),

\footnotetext{
86 Transformações estas detalhadas mais profundamente no Capítulo 1 - Educação Superior, Avaliação e Qualidade.
} 
[...] o mais problemático [...] é a necessidade de conciliar a regulação, isto é, o reconhecimento de padrões, a acreditação de títulos pelo Estado, de instituições que fazem do lucro seu principal, embora muitas vezes oculto, objetivo final (SGUISSARDI, 2008, p. 1012)

Identifica-se uma situação que, segundo o autor, o mercado educacional pode passar pelos mesmos problemas do mercado em geral - pouco comprometimento com as condições de trabalho dos docentes, pouca qualidade dos produtos ofertados, falta de ética na prestação de serviços, etc. E é justamente neste contexto em que o debate produzido em relação ao tema constata que o ProUni acaba reforçando esta lógica, especialmente em torno da mercadorização educacional e da oligopolização, por meio dos benefícios fiscais proporcionados às IES. A constatação de flexibilização e pouca clareza na legislação acerca do processo de avaliação (este que por sua vez, já possui questionamentos em âmbito nacional), dos cursos do Programa nestas instituições de ensino, pode resultar em poucos desvinculamentos (embora não tenham sido encontradas estatísticas, ou informações oficiais a esse respeito). Considerando, em especial, que políticas públicas possuem contextos de implementação bastante demarcados, envolvendo jogo de interesses e disputas por poder, é importante entender qual o papel que o ProUni assume nas disputas do campo da educação superior brasileira - cuja dicotomia mais notável nas últimas décadas refere-se entre as os setores público versus privado.

Por fim, é necessário mencionar que este trabalho foi baseado em uma concepção de qualidade (o indicador de qualidade oficial do Conceito Preliminar de Curso), dentre as diversas concepções que poderiam estar relacionadas ao termo - que, por sua vez, é conhecido pela falta de construção de consensos no âmbito do debate educacional, não apenas brasileiro, mas mundial. Embora não seja este o objetivo principal deste trabalho, é importante problematizar os limites e possibilidades do CPC enquanto indicador de qualidade de cursos superiores, observando sua criação e sua utilização como um resultado de decisões não apenas técnicas, mas que refletem contextos teóricos e políticos (BARREYRO, 2008b), e considerando que o ato de avaliar é um processo de construção de juízos de valores para tomadas de decisões, constituindo um espaço e um processo indispensável na perspectiva da melhoria da qualidade de todas as atividades relacionadas ao ensino.

Ao mesmo tempo que o CPC possui um enorme peso, e atribuição de significado para a operacionalização da avaliação de cursos de graduação no Brasil - constituindo-se, atualmente, como a medida oficial de qualidade desses cursos no país, e sendo uma das principais referências para a formulação de estatísticas educacionais e políticas públicas da área 
-, também foi observado que não faltam críticas à sua construção, sua metodologia e à (falta de?) integração com os demais aspectos idealizados pelo SINAES.

Algumas dessas críticas envolvem os seguintes aspectos: a dispensa automática de avaliações presenciais, promovida com a instituição desse indicador; a ausência da geração de resultados para todos os cursos superiores anualmente, já que o cálculo baseia-se nos insumos do ENADE - que, por sua vez, avalia trienalmente os cursos; o indicador passou por diversas mudanças metodológicas, o que gerou questionamentos sobre sua consistência técnica e comparabilidade dos resultados; a alta participação dos estudantes na nota final do indicador, a despeito da subjetividade intrínseca a esse modo de avaliação; e, por fim, o indicador desconsidera a heterogeneidade de IES e cursos em seu cálculo e na divulgação dos resultados. Portanto, reitera-se que é sempre necessário, quando da utilização de dados do CPC, considerar as limitações desse indicador, em especial sobre o que está sendo medido e qual a concepção de qualidade que está envolvida.

Conforme explicitado no Capítulo 1, na discussão sobre Qualidade da Educação Superior, configura-se como um exercício importante refletir sobre qual(is) concepção(ões) de qualidade está(ão) em jogo, e mais ainda, de que forma a acepção que é dada a esse conceito relaciona-se com o modelo de avaliação proposto. De acordo com as palavras de Dias Sobrinho (2008), a noção de qualidade, portanto, acaba atrelada às práticas vigentes, de quem as define e para quem.

Certamente, como foi observado durante este trabalho, qualidade e avaliação são conceitos estreitamente ligados, possuindo imensa complexidade e difíceis consensos, o que de fato proporciona muito mais questionamentos, do que conclusões. Por outro lado, entende-se que o caráter de polissemia desses conceitos não pode ser utilizado como pretexto para fugir da discussão em torno de seus significados, processos de construção e aplicação. 


\section{REFERÊNCIAS}

ALMEIDA, Wilson Mesquita de. O ProUni e a "democratização do ensino superior": explorações empíricas e conceituais. In: $33^{a}$ REUNIÃO ANUAL DA ANPEd, 2010, Caxambu. Anais da 33 ${ }^{\text {a }}$ Reunião da ANPEd. Caxambu: ANPEd, 2010. Disponível em: $<$ http://33reuniao.anped.org.br/33encontro/app/webroot/files/file/Trabalhos\%20em\%20PDF/ GT11-6232--Res.pdf>. Acesso em: 12 ago. 2015.

ALMEIDA, Wilson Mesquita de. Ampliação do acesso ao ensino superior privado lucrativo brasileiro: um estudo sociológico com bolsistas do ProUni na cidade de São Paulo. Tese (Doutorado), Programa de Pós Graduação em Sociologia, Universidade de São Paulo, São Paulo, 2012.

AMARAL, Daniela Patti do; OLIVEIRA, Fátima Bayma de. O Prouni e a conclusão do ensino superior: novas trajetórias pessoais e profissionais dos egressos. Ensaio: Avaliação e Políticas Públicas em Educação, Rio de Janeiro, v. 19, n. 73, p. 861-890, out/dez. 2011.

AQUINO, Yara. 40\% dos alunos de ensino superior usam Prouni ou Fies, diz ministro. Portal UOL Educação, 02 dez. 2014. Disponível em: <http://educacao.uol.com.br/noticias/2014/12/ 02/40-dos-alunos-de-ensino-superior-usam-prouni-ou-fies-diz-ministro.htm>. Acesso em: 10 dez. 2015.

BARRETO, Raquel Goulart; LEHER, Roberto. Do discurso e das condicionalidades do Banco Mundial, a educação superior "emerge" terciária. Revista Brasileira de Educação, Rio de Janeiro, v. 13, n. 39, p. 423-598, set/dez. 2008.

BARRETTO, Elba Siqueira de Sá. Perspectivas teóricas e metodológicas da pesquisa em política educacional na atualidade. Estudos em Avaliação Educacional, São Paulo, vol. 20, n.44, p. 493-507, set/dez. 2009.

BARREYRO, Gladys Beatriz. Mapa do Ensino Superior Privado. Brasília: INEP, 2008a. Disponível em: <http://each.uspnet.usp.br/gladysb/Mapa\%20do\%20ensino\%20 superior \%20privado.pdf >. Acesso em: 22 mai. 2015.

BARREYRO, Gladys Beatriz. De exames, rankings e mídia. Avaliação, Campinas; Sorocaba, v. 13 , n. 3, p. 863-868, nov. 2008b.

BARREYRO, Gladys Beatriz; COSTA, Fábio Luciano Oliveira. Las políticas de educación superior em Brasil en la primera década del siglo XXI: algunas evidencias sobre impactos positivos em la equidad. Revista Mexicana de Investigación Educativa, vol. 20, núm. 64, p. 17-46, jan/mar. 2015.

BARREYRO, Gladys Beatriz; ROTHEN, José Carlos. "SINAES” contraditórios: considerações sobre a elaboração e implantação do Sistema Nacional de Avaliação da Educação Superior. Educação \& Sociedade, Campinas, vol. 27, n. 96 - Especial, p. 955-977, out. 2006. 
BARREYRO Gladys Beatriz; ROTHEN, José Carlos. Para uma história da avaliação da educação superior brasileira: análise dos documentos do PARU, CNRES, GERES e PAIUB. Avaliação, Campinas, vol. 13, n. 3, p.131-152, mar. 2008.

BARREYRO, Gladys Beatriz; ROTHEN, José Carlos (org). Avaliação da educação: diferentes abordagens críticas. São Paulo: Xamã, 2011.

BARREYRO, Gladys Beatriz; ROTHEN, José Carlos. Percurso da avaliação da educação superior nos Governos Lula. Educação e Pesquisa, São Paulo, v. 40, n. 1, p. 61-76, jan./mar. 2014.

BRASIL. Decreto $n^{\circ}$ 2.207, de 15 de abril de 1997. Regulamenta, para o Sistema Federal de Ensino, as disposições contidas nos arts. 19, 20, 45, 46 e $\S 1^{\circ}$, 52, parágrafo único, 54 e 88 da Lei ${ }^{\circ}$ 9.394, de 20 de dezembro de 1996, e dá outras providências. Diário Oficial da União, Brasília, DF, 16 abr. 1997a. Disponível em: <http://www.planalto.gov.br/ccivil_03/decreto/ D2207.htm>. Acesso em: 02 dez. 2014.

BRASIL. Decreto no 2.306, de 19 de agosto de 1997. Regulamenta, para o Sistema Federal de Ensino, as disposições contidas no art. 10 da Medida Provisória ${ }^{\circ}$ 1.477-39, de 8 de agosto de 1997, e nos arts. 16, 19, 20, 45, 46 e $\S 1^{\circ}, 52$, parágrafo único, 54 e 88 da Lei $n^{\circ} 9.394$, de 20 de dezembro de 1996, e dá outras providências. Diário Oficial da União, Brasília, DF, 20 ago. 1997b. Disponível em: <http://www.planalto.gov.br/ccivil_03/decreto/ D2306.htm>. Acesso em: 02 dez. 2014.

BRASIL. Decreto $n^{\circ} 5.493$, de 18 de julho de 2005. Regulamenta o disposto na Lei no 11.096, de 13 de janeiro de 2005. Diário Oficial da União, Brasília, DF, 19 jul. 2005c. Disponível em: <http://www.planalto.gov.br/ccivil_03/_Ato2004-2006/2005/Decreto/ D5493.htm>. Acesso em: 30 out. 2014.

BRASIL. Decreto n 5.773 de 09 de maio de 2006. Dispõe sobre o exercício das funções de regulação, supervisão e avaliação de instituições de educação superior e cursos superiores de graduação e sequenciais no sistema federal de ensino. Diário Oficial da União, Brasília, DF, 10 mai. 2006a. Disponível em: <http://www2.mec.gov.br/ sapiens/portarias/dec5773.htm>. Acesso em: 22 fev. 2016.

BRASIL. Decreto $\mathrm{n}^{\circ} 5.800$, de 8 de Junho de 2006. Dispõe sobre o Sistema Universidade Aberta do Brasil - UAB. Diário Oficial da União, Brasília, DF, 09 jun. 2006b. Disponível em: <http://www.planalto.gov.br/ccivil_03/decreto/ D2207.htm>. Acesso em: 02 dez. 2014. BRASIL. Decreto ${ }^{\circ} 6.095$, de 24 de abril de 2007. Estabelece diretrizes para o processo de integração de instituições federais de educação tecnológica, para fins de constituição dos Institutos Federais de Educação, Ciência e Tecnologia - IFET, no âmbito da Rede Federal de Educação Tecnológica. Diário Oficial da União, Brasília, DF, 25 abr. 2007c. Disponível em: <http://www.planalto.gov.br/ccivil_03/_ato2007-2010/2007/decreto/d6095.htm>. Acesso em: 26 jan. 2015.

BRASIL. Decreto n ${ }^{\circ}$ 6.096, de 24 de abril de 2007. Institui o Programa de Apoio a Planos de Reestruturação e Expansão das Universidades Federais - REUNI. Diário Oficial da União, Brasília, DF, 25 abr. 2007d. Disponível em: <http://www.planalto.gov.br/ccivil_03/_ato20072010/2007/decreto/d6096.htm>. Acesso em: 26 jan. 2015. 
BRASIL. Medida Provisória no 213, de 10 de setembro de 2004. Institui o Programa Universidade para Todos - PROUNI, regula a atuação de entidades beneficentes de assistência social no ensino superior, e dá outras providências. Diário Oficial da União, Brasília, DF, 13 set. 2004c. Disponível em: <http://www.planalto.gov. br/ccivil_03/_Ato20042006/2004/Mpv/213.htm>. Acesso em: 30 out. 2014.

BRASIL. Projeto de lei $\mathbf{n}^{\mathbf{0}} \mathbf{3 . 5 8 2}$, de 28 de abril de 2004d. Dispõe sobre a instituição do Programa Universidade para Todos - PROUNI, e dá outras providências. Disponível em: <http://www.camara.gov.br/sileg/integras/219649.pdf>. Acesso em: 28 out. 2014.

BRASIL. Lei ${ }^{\circ}$ 9.131, de 24 de Novembro de 1995. Altera dispositivos da Lei $\mathrm{n}^{\circ} 4.024$, de 20 de dezembro de 1961, e dá outras providências. Diário Oficial da União, Brasília, DF, 25 nov. 1995. Disponível em: < http://www.planalto.gov.br/ccivil_03/Leis/L9131.htm>. Acesso em: 13 ago. 2014.

BRASIL. Lei n 9.394, de 20 de Dezembro de 1996. Estabelece as diretrizes e bases da educação nacional. Diário Oficial da União, Brasília, DF, 23 dez. 1996. Disponível em: <http://www.planalto.gov.br/CCIVIL_03/leis/L9394.htm>. Acesso em: 02 out. 2014. BRASIL. Lei no 10.172, de 9 de janeiro de 2001. Estabelece o Plano Nacional de Educação. Diário Oficial da União, Brasília, DF, 10 jan. 2001. Disponível em:

<http://portal.mec.gov.br/arquivos/pdf/L10172.pdf>. Acesso em: 15 jan. 2016.

BRASIL. Lei n ${ }^{\circ}$ 10.861, de 14 de Abril de 2004. Institui o Sistema Nacional de Avaliação da Educação Superior - SINAES e dá outras providências. Diário Oficial da União, Brasília, DF, 15 abr. 2004b. Disponível em: <http://www.planalto.gov.br/ ccivil_03/_ato20042006/2004/lei/110.861.htm>. Acesso em: 09 out. 2014.

BRASIL. Lei ${ }^{\circ} 11.096$, de 13 de janeiro de 2005. Institui o Programa Universidade para Todos - PROUNI, regula a atuação de entidades beneficentes de assistência social no ensino superior; altera a Lei n. 10.891, de 9 de julho de 2004, e dá outras providências. Diário Oficial da União, Brasília, DF, 14 jan. 2005a. Disponível em: <http://www.planalto.gov.br/ 2005/Lei/L11096.htm>. Acesso em: 11 ago. 2014.

BRASIL. Lei n ${ }^{\circ} 11.180$, de 23 de Setembro de 2005. Institui o Projeto Escola de Fábrica, autoriza a concessão de bolsas de permanência a estudantes beneficiários do Programa Universidade para Todos - PROUNI, institui o Programa de Educação Tutorial - PET, altera a Lei no 5.537, de 21 de novembro de 1968, e a Consolidação das Leis do Trabalho - CLT, aprovada pelo Decreto-Lei no 5.452, de 1o de maio de 1943, e dá outras providências. Diário Oficial da União, Brasília, DF, 26 set. 2005d. Disponível em: <http://www.planalto.gov.br/ ccivil_03/_ato2004-2006/2005/lei/L11180.htm>. Acesso em: 28 out. 2014.

BRASIL. Lei $n^{\circ} 11.509$, de 20 de Julho de 2007. Altera o $§ 40$ do art. 7o da Lei $n^{\circ} 11.096$, de 13 de janeiro de 2005, que instituiu o Programa Universidade para Todos - PROUNI, para dispor sobre a desvinculação dos cursos com desempenho insuficiente no Sistema Nacional de Avaliação da Educação Superior - SINAES. Diário Oficial da União, Brasília, DF, 23 jul. 2007b. Disponível em: <http://www.planalto.gov.br/ ccivil_03/_Ato20072010/2007/Lei/L11509.htm>. Acesso em: 30 out. 2014.

BRASIL. Lei ${ }^{\circ}$ 12.431, de 24 de Junho de 2011. Dispõe sobre a incidência do imposto sobre a renda nas operações que especifica; altera as Leis $\mathrm{n}^{\circ}$ s 11.478, de 29 de maio de 2007, 6.404, 
de 15 de dezembro de 1976, 9.430, de 27 de dezembro de 1996 , 12.350, de 20 de dezembro de $2010,11.196$, de 21 de novembro de 2005 , 8.248, de 23 de outubro de 1991, 9.648, de 27 de maio de 1998, 11.943, de 28 de maio de 2009, 9.808, de 20 de julho de 1999, 10.260, de 12 de julho de 2001, 11.096, de 13 de janeiro de 2005 , 11.180, de 23 de setembro de 2005, 11.128 , de 28 de junho de $2005,11.909$, de 4 de março de 2009, 11.371, de 28 de novembro de $2006,12.249$, de 11 de junho de $2010,10.150$, de 21 de dezembro de 2000, 10.312, de 27 de novembro de 2001, e 12.058, de 13 de outubro de 2009, e o Decreto-Lei ${ }^{\circ} 288$, de 28 de fevereiro de 1967 ; institui o Regime Especial de Incentivos para o Desenvolvimento de Usinas Nucleares (Renuclear); dispõe sobre medidas tributárias relacionadas ao Plano Nacional de Banda Larga; altera a legislação relativa à isenção do Adicional ao Frete para Renovação da Marinha Mercante (AFRMM); dispõe sobre a extinção do Fundo Nacional de Desenvolvimento; e dá outras providências. Diário Oficial da União, Brasília, DF, 27 jun. 2011b. Disponível em: < http://www.planalto.gov.br/ccivil_03/_ato2011-2014/2011/lei/ 112431.htm>. Acesso em: 30 out. 2014.

BRASIL. Lei $\mathrm{n}^{\circ}$ 12.527, de 18 de novembro de 2011. Regula o acesso a informações previsto no inciso XXXIII do art. 5o, no inciso II do § 3o do art. 37 e no § 2o do art. 216 da Constituição Federal; altera a Lei no 8.112, de 11 de dezembro de 1990; revoga a Lei no 11.111, de 5 de maio de 2005, e dispositivos da Lei no 8.159, de 8 de janeiro de 1991; e dá outras providências. Diário Oficial da União, Brasília, DF, 18 nov. 2011c. Disponível em: <http://www.planalto.gov.br/ccivil_03/_ato2011-2014/2011/lei/112527.htm>. Acesso em: 23 out. 2014.

BRASIL. Lei $\mathrm{n}^{\circ} 12.711$, de 29 de agosto de 2012. Dispõe sobre o ingresso nas universidades federais e nas instituições federais de ensino técnico de nível médio e dá outras providências. Diário Oficial da União, Brasília, DF, 30 ago. 2012f. Disponível em: <http://www.planalto. gov.br/ccivil_03/_ato2011-2014/2012/lei/112711.htm>. Acesso em: 14 out. 2014.

BRASIL. Lei no 13.005, de 25 de junho de 2014. Aprova o Plano Nacional de Educação PNE e dá outras providências. Diário Oficial da União, Brasília, DF, 26 jun. 2014h.

Disponível em: < http://www.planalto.gov.br/ccivil_03/_ato2011-2014/2014/lei/113005.htm>. Acesso em: 04 fev. 2015.

BRASIL. Banco Central do Brasil. Focus - Relatório de Mercado. 31 dez. 2015c. Disponível em: <http://www.bcb.gov.br/pec/GCI/PORT/readout/R20151231.pdf>. Acesso em: 16 jan. 2016.

BRASIL. Banco Central do Brasil. Histórico das taxas de juros. 2016b. Disponível em: <https://www.bcb.gov.br/?COPOMJUROS>. Acesso em: 22 jan. 2016.

BRASIL. Conselho Nacional de Desenvolvimento Científico e Tecnológico (CNPq). Bolsas e Taxas no país. 2016d. Disponível em: <http://cnpq.br/no-pais〉. Acesso em: 18 jan. 2016. BRASIL. Constituição da República Federativa do Brasil. 1988. São Paulo: Imprensa Oficial, 1999.

BRASIL. Governo Federal. Portal Brasil. 2016f. Disponível em: 〈http://www.brasil.gov.br>. Acesso em: 07 fev. 2016.

BRASIL. Governo Federal. Programa Universidade para Todos (ProUni). 2015h.

Disponível em: <http://siteprouni.mec.gov.br>. Acesso em: 16 jan. 2016. 
BRASIL. Instituto Nacional de Estudos e Pesquisas Educacionais Anísio Teixeira (INEP). Censo da Educação Superior 2002 - Resumo Técnico. Brasília: INEP, 2003.

BRASIL. Instituto Nacional de Estudos e Pesquisas Educacionais Anísio Teixeira (INEP). Censo da Educação Superior 2003 - Resumo Técnico. Brasília: INEP, 2004a.

BRASIL. Instituto Nacional de Estudos e Pesquisas Educacionais Anísio Teixeira (INEP). Censo da Educação Superior 2004 - Resumo Técnico. Brasília: INEP, 2005 b.

BRASIL. Instituto Nacional de Estudos e Pesquisas Educacionais Anísio Teixeira (INEP). Boletim de Estudos Educacionais Na Medida. Ano 1, n. 3. Brasília: INEP, set. 2009b. Disponível em: <http://download.inep.gov.br/publicacoes/2009/boletim_na_medida/ Boletim_Na_Medida_4.pdf $>$. Acesso em 12 jun. 2014.

BRASIL. Instituto Nacional de Estudos e Pesquisas Educacionais Anísio Teixeira (INEP). Nota Técnica - Aplicação do Conceito Preliminar de Cursos de Graduação (CPC) na avaliação do Sistema Nacional de Avaliação da Educação Superior - SINAES. Brasília: INEP, 2009c. Disponível em: <http://download.inep.gov.br/ download/enade/2009/2008_ Nota_Tecnica_Aplicacao-do-CPC-na-avaliacao-de-cursos.pdf $>$. Acesso em: 13 jul. 2015.

BRASIL. Instituto Nacional de Estudos e Pesquisas Educacionais Anísio Teixeira (INEP). Nota Técnica - Cálculo do Conceito Preliminar de Curso 2008. Brasília: INEP, 2009d. Disponível em: <http://download.inep.gov.br/download/enade/2008/Nota_Tecnica_CPC_ 17_12_2009.pdf $>$. Acesso em: 31 jul. 2015.

BRASIL. Instituto Nacional de Estudos e Pesquisas Educacionais Anísio Teixeira (INEP). Nota Técnica - Cálculo do Conceito Preliminar de Curso 2009. Brasília: INEP, 2010b. Disponível em: < http://download.inep.gov.br/download/enade/2009/Nota_Tecnica_ CPC.pdf >. Acesso em: 31 jul. 2015.

BRASIL. Instituto Nacional de Estudos e Pesquisas Educacionais Anísio Teixeira (INEP). Nota Técnica - Cálculo do Conceito Preliminar de Curso 2010. Brasília: INEP, 2011d. Disponível em: <http://download.inep.gov.br/educacao_superior/enade/notas_tecnicas/2010/ nota_tecnica_cpc_05092011.pdf $>$. Acesso em: 02 ago. 2015.

BRASIL. Instituto Nacional de Estudos e Pesquisas Educacionais Anísio Teixeira (INEP). Censo da Educação Superior 2010 - Resumo Técnico. Brasília: INEP, 2012b.

BRASIL. Instituto Nacional de Estudos e Pesquisas Educacionais Anísio Teixeira (INEP). Nota Técnica $n^{\circ}$ 29/2012 - Cálculo do Conceito Preliminar de Curso (CPC) referente ao ano de 2011. Brasília: INEP, out. 2012c. Disponível em: <http://download.inep.gov.br/ educacao_superior/enade/notas_tecnicas/2011/nota_tecnica_indicadores_2011_2.pdf>. Acesso em: 10 mai. 2015.

BRASIL. Instituto Nacional de Estudos e Pesquisas Educacionais Anísio Teixeira (INEP). Manual dos Indicadores de Qualidade 2011. Brasília: INEP, 2012e. Disponível em: <http:// download.inep.gov.br/educacao_superior/enade/notas_tecnicas/2011/manual_indicadores_qua lidade_2011_sem_logo.pdf>. Acesso em: 05 ago. 2015. 
BRASIL. Instituto Nacional de Estudos e Pesquisas Educacionais Anísio Teixeira (INEP). Nota Metodológica - Indicadores de Qualidade da Educação Superior 2012. Brasília: INEP, out. 2013a. Disponível em: <http://download.inep.gov.br/educacao_superior/enade/ notas_tecnicas/2012/nota_metodologica_indicadores_2012.pdf $>$. Acesso em: 04 mai. 2015.

BRASIL. Instituto Nacional de Estudos e Pesquisas Educacionais Anísio Teixeira (INEP). Medidas de Regulação e Supervisão - CPC e IGC 2012. Brasília: INEP, 2013b. Disponível em: <http://download.inep.gov.br/educacao_superior/enade/documentos/2013/regulacao_ supervisao_medidas.pdf>. Acesso em: 04 mai. 2015.

BRASIL. Instituto Nacional de Estudos e Pesquisas Educacionais Anísio Teixeira (INEP). Censo da Educação Superior 2012 - Resumo Técnico. Brasília: INEP, 2013c.

BRASIL. Instituto Nacional de Estudos e Pesquisas Educacionais Anísio Teixeira (INEP). Nota Técnica n 70 - Utilização dos Insumos do Questionário do Estudante Aplicado em 2013. Brasília: INEP, out 2014a. Disponível em: <http://download.inep.gov.br/educacao_ superior/enade/notas_tecnicas/2013/nota_tecnica_n_70_2014_utilizacao_insumos_questionari o_estudante_2013.pdf >. Acesso em: 04 mai. 2015.

BRASIL. Instituto Nacional de Estudos e Pesquisas Educacionais Anísio Teixeira (INEP). Resultados do Conceito Preliminar de Curso 2012. Brasília, mar. 2014d. Disponível em: <http://download.inep.gov.br/educacao_superior/enade/planilhas/2012/cpc_2012_ site_2014_03_14.xls>. Acesso em: 12 mai. 2015.

BRASIL. Instituto Nacional de Estudos e Pesquisas Educacionais Anísio Teixeira (INEP). Nota Técnica $\mathrm{n}^{\circ} 72$ - Cálculo do Conceito Preliminar de Curso referente a 2013. Brasília: INEP, 2014f. Disponível em: <http://download.inep.gov.br/educacao_superior/enade/ notas_tecnicas/2013/nota_tecnica_n_72_2014_calculo_cpc_2013.pdf $>$. Acesso em: 02 ago. 2015.

BRASIL. Instituto Nacional de Estudos e Pesquisas Educacionais Anísio Teixeira (INEP). Sinopses Estatísticas da Educação Superior - Graduação - 2013. 2015b. Disponível em: <http://portal.inep.gov.br/superior-censosuperior-sinopse>. Acesso em: 03 fev. 2016.

BRASIL. Instituto Nacional de Estudos e Pesquisas Educacionais Anísio Teixeira (INEP). Exame Nacional de Desempenho dos Estudantes - ENADE. 2015e. Disponível em: <http:// portal.inep.gov.br/enade>. Acesso em: 03 fev. 2016.

BRASIL. Instituto Nacional de Estudos e Pesquisas Educacionais Anísio Teixeira (INEP). Manual do ENADE - 2015. Brasília: INEP, mai. 2015f. Disponível em: <http://download. inep.gov.br/educacao_superior/enade/manuais/manual_enade_2015_30062015.pdf>.Acesso em: 04 fev. 2016.

BRASIL. Instituto Nacional de Estudos e Pesquisas Educacionais Anísio Teixeira (INEP). Seminários Enade 2015 - O Enade no Sistema Nacional de Avaliação da Educação Superior (SINAES). Brasília, jun. 2015g. Disponível em: <http://download.inep.gov.br/ educacao_superior/enade/seminarios/2015/o_sinaes_e_o_enade.pdf >. Acesso em: 04 fev. 2016. 
BRASIL. Instituto Nacional de Estudos e Pesquisas Educacionais Anísio Teixeira (INEP). Evolução da Educação Superior - Graduação - 1980-1998. Brasília: INEP, 2016a. Disponível em: <http://download.inep.gov.br/download/censo/1998/superior/ evolucao_19801998.zip>. Acesso em: 10 fev. 2016.

BRASIL. Instituto Nacional de Estudos e Pesquisas Educacionais Anísio Teixeira (INEP). Indicadores Financeiros Educacionais. Brasília, 2016c. Disponível em: <http://portal. inep.gov.br/indicadores-financeiros-educacionais>. Acesso em: 07 fev. 2016.

BRASIL. Instituto Nacional de Estudos e Pesquisas Educacionais Anísio Teixeira (INEP). Conceito Preliminar de Curso - CPC. Brasília, 2016h. Disponível em: <http://portal.inep. gov.br/educacao-superior/indicadores/cpc>. Acesso em: 20 fev. 2016.

BRASIL. Ministério da Educação. Portaria Normativa n 40, de 12 de dezembro de 2007. Institui o e-MEC, sistema eletrônico de fluxo de trabalho e gerenciamento de informações relativas aos processos de regulação da educação superior no sistema federal de educação. Diário Oficial da União, Brasília, DF, 12 dez. 2007a. Disponível em: < http://uab.capes. gov.br/images/stories/downloads/legislacao/portarian40.pdf>. Acesso em: 15 ago. 2015.

BRASIL. Ministério da Educação. Portaria Normativa n² 4, de 05 de agosto de 2008. Regulamenta a aplicação do conceito preliminar de cursos superiores - CPC, para fins dos processos de renovação de reconhecimento respectivos, no âmbito do ciclo avaliativo do SINAES instaurado pela Portaria Normativa no 1 , de 2007. Diário Oficial da União, Brasília, DF, 06 ago. 2008a. Disponível em: <http://download.inep.gov.br/ download/superior/ condicoesdeensino/Portaria_N_4_de_5_de_agosto_2008.pdf >. Acesso em: $18 \mathrm{dez} .2014$.

BRASIL. Ministério da Educação. Portaria Normativa n ${ }^{\circ}$ 12, de 05 de setembro de 2008. Institui o Índice Geral de Cursos da Instituição de Educação Superior (IGC). Diário Oficial da União, Brasília, DF, 08 set. 2008b. Disponível em: <http://download.inep.gov.br/ download/condicoes_ensino/2008/PORTARIA_NORMATIVA_12.pdf >. Acesso em: 18 dez. 2014.

BRASIL. Ministério da Educação. Portaria Normativa no 40, de 29 de dezembro de 2.010. Institui o e-MEC, sistema eletrônico de fluxo de trabalho e gerenciamento de informações relativas aos processos de regulação, avaliação e supervisão da educação superior no sistema federal de educação, e o Cadastro e-MEC de Instituições e Cursos Superiores e consolida disposições sobre indicadores de qualidade, banco de avaliadores (Basis) e o Exame Nacional de Desempenho de Estudantes (ENADE) e outras disposições. Diário Oficial da União, Brasília, DF, 29 dez. 2010a. Disponível em: <http://download.inep.gov.br/download/superior/ 2011/portaria_normativa_n40_12_dezembro_2007.pdf>. Acesso em: 10 out. 2014.

BRASIL. Ministério da Educação. Portaria Normativa nº 2, de 19 de janeiro de 2011. Regulamenta o processo seletivo do Programa Universidade para Todos - ProUni referente ao primeiro semestre de 2011 e dá outras providências. Diário Oficial da União, Brasília, DF, 21 jan. 2011a. Disponível em: <http://prouniportal.mec.gov.br/index.php?option=com_ docman\&task=doc_details\&gid=152\&Itemid=>. Acesso em: 23 set. 2014.

BRASIL. Ministério da Educação. Portaria Normativa nº 1, de 06 de janeiro de 2012. Regulamenta o processo seletivo do Programa Universidade para Todos - ProUni referente ao primeiro semestre de 2012 e dá outras providências. Diário Oficial da União, Brasília, DF, 
09 jan. 2012d. Disponível em: <http://prouniportal.mec.gov.br/index.php?option= com_docman\&task=doc_details\&gid=173\&Itemid=122>. Acesso em: 03 out. 2014.

BRASIL. Ministério da Educação. Portaria Normativa n 11, de 23 de abril de 2014. Dispõe sobre os procedimentos para a adesão de mantenedoras de Instituições de Educação Superior e a emissão de Termo Aditivo ao processo seletivo do Programa Universidade para Todos ProUni referente ao segundo semestre de 2014, e dá outras providências. Diário Oficial da União, Brasília, DF, 24 abr. 2014c. Disponível em: <http://prouniportal.mec.gov.br/index. php?option=com_docman \&task=doc_download\&gid=206\&Itemid=122>. Acesso em: 05 jan. 2015.

BRASIL. Ministério da Educação. Portaria Normativa n ${ }^{\circ}$ 21, de 26 de dezembro de 2014. Altera dispositivos das Portarias Normativas MEC n 2, de 31 de agosto de 2008; no 1, de 22 de janeiro de 2010; $\mathrm{n}^{\mathrm{o}} 10$, de 30 de abril de 2010; $\mathrm{n}^{\mathrm{o}} 15$, de 8 de julho de 2011; no 23, de 10 de novembro de 2011; $\mathrm{n}^{\circ} 25$, de 22 de dezembro de 2011; $\mathrm{n}^{\circ} 16$, de 4 de setembro de 2012; $\mathrm{n}^{\circ}$ 19, de 31 de outubro de 2012; e n ${ }^{\text {o } 28}$, de 28 de dezembro de 2012, que dispõem sobre o Fundo de Financiamento Estudantil - FIES. Diário Oficial da União, Brasília, DF, 29 dez. 2014b. Disponível em: <http://sisfiesportal.mec.gov.br/arquivos/portaria_normativa_21_ 26122014_compilada_050115.pdf>. Acesso em: 03 ago. 2015.

BRASIL. Ministério da Educação. Portaria Normativa nº 1, de 02 de janeiro de 2015. Regulamenta os processos seletivos do Programa Universidade para Todos - ProUni. Diário Oficial da União, Brasília, DF, 05 jan. 2015i. Disponível em: <http://prouniportal.mec. gov.br/legislacao/legislacao-2015/215-portaria-normativa-n-1-de-2-de-janeiro-de-2015/file>. Acesso em: 16 jan. 2016.

BRASIL. Ministério da Educação. Portaria Normativa n ${ }^{\circ}$ 13, de 11 de dezembro de 2015. Dispõe sobre o processo seletivo do Fundo de Financiamento Estudantil - Fies referente ao primeiro semestre de 2016. Diário Oficial da União, Brasília, DF, 14 dez 2015d. Disponível em: <http://fiesselecao.mec.gov.br/arquivos/port_normativa_13_11122015.pdf>. Acesso em: 03 fev. 2016.

BRASIL. Ministério da Educação. Análise sobre a Expansão das Universidades Federais 2003 a 2012. Brasília, 2012a. Disponível em: <http://portal.mec.gov.br/index.php? option=com_docman\&view=download \&alias=12386-analise-expansao-universidadefederais-2003-2012-pdf\&Itemid=30192> . Acesso em: 12 nov. 2015.

BRASIL. Ministério da Educação. E-MEC. Sistema online das Instituições de Educação Superior e Cursos Cadastrados no MEC. 2014e. Disponível em: <http://emec.mec.gov.br>. Acesso em: 25 out. 2014.

BRASIL. Ministério da Educação. Secretaria de Educação Superior. Fundo de Financiamento Estudantil (Fies). Prestação de Contas Ordinárias Anual. Relatório de Gestão do Exercício de 2014. Brasília: MEC, abr. 2015a. Disponível em: <http://portal.mec.gov.br/ index.php?option=com_docman\&view=download\&alias $=17528$-fies-relatorio-gestao-pcoaexercicio-2014-tcu\&Itemid=30192>. Acesso em: 29 dez. 2015.

BRASIL. Ministério da Educação e do Desporto. Secretaria do Ensino Superior. Programa de Avaliação Institucional das Universidades Brasileiras. Brasília, DF, 1994. 
BRASIL. Ministério da Fazenda. Receita Federal do Brasil. Demonstrativo dos Gastos Governamentais Indiretos de Natureza Tributária (Gastos Tributários) 2005 - 2016. 2016g. Disponível em: <http://idg.receita.fazenda.gov.br>. Acesso em: 20 fev. 2016.

BRASIL. Ministério do Desenvolvimento Social e Combate à Fome. Certificação de Entidades de Assistência Social. 2016e. Disponível em: <http://mds.gov.br/assuntos/ assistencia-social/entidade-de-assistencia-social/certificacao-de-entidades-de-assistenciasocial>. Acesso em: 26 jan. 2016.

BRASIL. Sistema Eletrônico do Serviço de Informação ao Cidadão (E-SIC). 2014g. Disponível em: <http://www.acessoainformacao.gov.br>. Acesso em: 04 fev. 2014.

BRASIL. Tribunal de Contas da União. Relatório de Auditoria Operacional: Programa Universidade para Todos (ProUni) e Fundo de Financiamento ao Estudante do Ensino Superior (FIES). Brasília: TCU, 2009a. Disponível em: <http://portal.tcu.gov.br/lumis/ portal/file/fileDownload.jsp?inline=1\&fileId=8A8182A14D92792C014D9283C47B77D7>. Acesso em: 24 set. 2014.

BERTOLIN, Júlio Cesar Godoy. Indicadores em Nível de Sistema para Avaliar o Desenvolvimento e a Qualidade da Educação Superior Brasileira. Avaliação, Campinas; Sorocaba, v. 12, n.2, p. 309-331, jun/2007.

BERTOLIN, Júlio Cesar Godoy. Qualidade em educação superior: da diversidade de concepções a inexorável subjetividade conceitual. Avaliação, Campinas; Sorocaba, v. 14, n. 1, p. 127-149, mar. 2009.

BERTOLIN, Júlio Cesar Godoy; MARCON, Telmo. O (des)entendimento de qualidade na educação superior brasileira - das quimeras do provão e do Enade à realidade do capital cultural dos estudantes. Avaliação, Campinas; Sorocaba, v. 20, n. 1, p. 105-122, mar. 2015.

BITTENCOURT, Hélio Radke; CASARTELLI, Alam de Oliveira; RODRIGUES, Alziro César de Morais. Sobre o Índice Geral de Cursos (IGC). Avaliação, Campinas; Sorocaba, SP, v. 14, n. 3, p. 667-682, nov. 2009.

BITTENCOURT, Hélio Radke; VIALI, Lorí; CASARTELLI, Alam de Oliveira; RODRIGUES, Alziro Cesar de Morais. Uma análise da relação entre os conceitos Enade e IDD. Estudos em Avaliação Educacional, v. 19, n. 40, p. 247-262, mai/ago. 2008.

BOURDIEU, Pierre; BOLTANSKI, Luc. O diploma e o cargo: relações entre o sistema de produção e o sistema de reprodução. In: NOGUEIRA, Maria Alice; CATANI, Afrânio Mendes (org). Pierre Bourdieu: Escritos de Educação. Petrópolis: Vozes, 2007, 251p.

BRANDÃO, Marisa. O Governo Lula e a chamada Educação Profissional Tecnológica.

Revista de Educação Técnica e Tecnológica em Ciências Agrícolas, Rio de Janeiro, Vol. I, $n^{\circ}$ 01, p. 61-87, jan./jun. 2010.

BURLAMAQUI, Marco Guilherme Bravo. Avaliação e Qualidade na Educação Superior: tendências na literatura e algumas implicações para o sistema de avaliação brasileiro. Estudos em Avaliação Educacional, São Paulo, v.19, n.39, p. 133-153, jan/abr. 2008. 
BUSSAB, Wilton de Oliveira; MORETTIN, Pedro Alberto. Estatística Básica. São Paulo: Saraiva, 2005.

CABRAL NETO, Antônio; CASTRO, Alda Maria Duarte Araújo. Gestão Educacional na América Latina: delineamentos e desafios para os sistemas de ensino. In: EYNG, Ana Maria; GISI, Maria Lourdes (org). Políticas e Gestão da Educação Superior: desafios e perspectivas. Ijuí: Ed. Unijuí, 2007.

CARVALHO, Cristina Helena Almeida de. O PROUNI no Governo Lula e o jogo político em torno do acesso ao ensino superior. Educação \& Sociedade, Campinas, v. 27, n 96 Especial, p. 979-1000, out. 2006.

CARVALHO, Cristina Helena Almeida de. Uma análise crítica do financiamento do PROUNI: instrumento de estímulo à iniciativa privada e/ou democratização do acesso à educação superior? In: 34a REUNIÃO ANUAL DA ANPEd, 2011, Natal. Anais da 34 Reunião da ANPEd, Natal: ANPEd, 2011a. Disponível em: <http://www.anped11. uerj.br/GT11-935\%20int.pdf>. Acesso em: 13 mai. 2015.

CARVALHO, Cristina Helena Almeida de. A política pública para a educação superior no Brasil (1995-2008): ruptura e/ou continuidade?. Tese (Doutorado), Instituto de Economia, Universidade Estadual de Campinas, Campinas, 2011b.

CARVALHO, Cristina Helena Almeida de. A mercantilização da educação superior brasileira e as estratégias de mercado das instituições lucrativas. Revista Brasileira de Educação, Rio de Janeiro, v. 18, n. 54, p. 761-801, jul-set. 2013.

CATANI, Afrânio Mendes; HEY, Ana Paula; GILIOLI, Renato de Sousa Porto. PROUNI: democratização do acesso às Instituições de Ensino Superior? Educar, Curitiba, n 28, p. 125-140, 2006.

CHAVES, Vera Lúcia Jacob; AMARAL, Nelson Cardoso. A educação superior no Brasil: os desafios da expansão e do financiamento e comparações com outros países. Revista Educação em Questão, Natal, v. 51, n. 37, p. 95-120, jan./abr. 2015

CM CONSULTORIA. Fusões e Aquisições no Ensino Superior - Panorama 2007-2014. Ago. 2014. Disponível em: < http://www.cmconsultoria.com.br/arquivos/GraficoAquisicoes IES2014-08-13.pdf>. Acesso em: 10 dez. 2015.

CORBUCCI, Paulo Roberto. Evolução do Acesso de Jovens à Educação Superior no Brasil. Texto para Discussão - Instituto de Pesquisa Econômica Aplicada. Brasília: Ipea, abr. 2014. Disponível em: <http://www.ipea.gov.br/portal/images/stories/PDFs/TDs/td_1950. pdf> . Acesso em: jun. 2014.

COSTA, Fabiana de Souza. Políticas Públicas de Educação Superior - Programa Universidade para Todos: um olhar dos alunos beneficiários na PUC-SP. Dissertação (Mestrado), Programa de Pós-Graduação em Educação, Pontifícia Universidade Católica de São Paulo, São Paulo, 2008. 
COSTA, Fabiana de Souza. O ProUni e seus egressos: uma articulação entre educação, trabalho e juventude. Tese (Doutorado), Programa de Pós-Graduação em Educação, Pontifícia Universidade Católica de São Paulo, São Paulo, 2012.

COSTA, Fabiana de Souza. O ProUni e seus egressos: perspectivas sobre qualificação profissional e acesso ao mercado de trabalho. Princípios, São Paulo, n. 123, p. 76-80, fevmar. 2013.

CUNHA, Luiz Antônio. A Universidade Crítica: o ensino superior na república populista. São Paulo: Ed. UNESP, 2007.

CUNHA, Luiz Antônio. O Ensino Superior no Octênio FHC. Educação \& Sociedade, Campinas, vol. 24, n. 82, p. 37-61, abr. 2003.

\section{DEPARTAMENTO INTERSINDICAL DE ESTATÍSTICA E ESTUDOS}

SOCIOECONÔMICOS (DIEESE). Boletim de Conjuntura no 4. Ago. 2015. Disponível em: <http://www.dieese.org.br/boletimdeconjuntura/2015/boletim Conjuntura004.pdf >. Acesso em: 13 set. 2015.

DIAS SOBRINHO, José. Universidade e Avaliação: entre a ética e o mercado.

Florianópolis: Insular, 2002.

DIAS SOBRINHO, José. Qualidade, avaliação: do SINAES a índices. Avaliação, Campinas; Sorocaba, vol. 13, n. 3, p. 817-825, nov. 2008a.

DIAS SOBRINHO, José. Avaliação da educação superior: avanços e riscos. EccoS Revista Científica, vol. 10, n. especial, p. 67-93, jul. 2008b.

DIAS SOBRINHO, José. Avaliação e transformações da educação superior brasileira (19952009): do provão ao SINAES. Avaliação, Campinas; Sorocaba, vol.15, n. 1, p. 195-224, mar. 2010 .

DIAS SOBRINHO, José. Educação Superior: bem público, equidade e democratização. Avaliação, Campinas; Sorocaba, v. 18, n. 1, p. 107-126, mar. 2013.

DIAS SOBRINHO, José; DIAS, Rafael de Brito. Acreditação da Educação Superior e C\&T: políticas e ideologia. Avaliação, Campinas, Sorocaba, v. 11, n. 04, p. 9-25, dez. 2006.

DOURADO, Luiz Fernandes. Reforma do Estado e as políticas para a educação superior no Brasil nos anos 90. Educação \& Sociedade, Campinas, vol. 23, n. 80, p. 234-252, set./2002.

FÁVERO, Maria de Lourdes de Albuquerque. Da Universidade "Modernizada" à

Universidade Disciplinada: Atcon e Meira Mattos. São Paulo: Cortez, 1991.

FÁVERO, Maria de Lourdes de Albuquerque. A Universidade no Brasil: das origens à Reforma Universitária de 1968. Educar, Curitiba, n. 28, p. 17-36, 2006.

FERNANDES, Reynaldo; PAZELLO, Elaine Toldo; LEITÃO, Thiago Miguel Sabino de Pereira; MORICONI, Gabriela Miranda. Avaliação de Cursos na Educação Superior: a 
função e a mecânica do Conceito Preliminar de Curso. Textos para discussão no ${ }^{\circ}$ 2, Brasília: INEP, 2009.

FRIGOTTO, Gaudêncio. Educação e a Crise do Capitalismo Real. São Paulo: Cortez, 1995.

FRIGOTTO, Gaudêncio. Ensino médio e técnico profissional: disputa de concepções e precariedade. Le Monde Diplomatique Brasil, São Paulo, nº68, 01 mar. 2013. Disponível em: <http://www.diplomatique.org.br/artigo.php?id=1384>. Acesso em: 10 out. 2014.

FUNDAÇÃO UNIVERSITÁRIA PARA O VESTIBULAR (FUVEST). Vestibular 2014. 2014. Disponível em: <http://www.fuvest.br>. Acesso em: 06 set. 2015.

GOMES, Alfredo Macedo. MORAES, Karine Numes de. Educação Superior no Brasil Contemporâneo: transição para um sistema de massa. Educação \& Sociedade, Campinas, v. 33, n. 118, p. 171-190, jan-mar. 2012.

GUTIERREZ, Marcelle. Após fusão, Kroton e Anhanguera passam a ser a $17^{\mathrm{a}}$ maior companhia da Bolsa. O Estado de S. Paulo, Caderno Economia e Negócios, São Paulo, 04 jul. 2014. Disponível em: <http://economia.estadao.com.br/noticias/negocios, apos-fusaokroton-e-anhanguera-passam-a-ser-a-17-maior-companhia-da-bolsa,1523573>. Acesso em: 08 jan. 2015.

INSTITUTO BRASILEIRO DE GEOGRAFIA E ESTATÍSTICA (IBGE). Censo Demográfico 2000. 2001. Disponível em: <http://www.ibge.gov.br/home/estatistica/ populacao/censo2000>. Acesso em: 09 out. 2014.

INSTITUTO BRASILEIRO DE GEOGRAFIA E ESTATÍSTICA (IBGE). Censo Demográfico 2010. 2011. Disponível em: 〈http://www.censo2010.ibge.gov.br〉. Acesso em: 09 out. 2014.

INSTITUTO BRASILEIRO DE GEOGRAFIA E ESTATÍSTICA (IBGE). Pesquisa Nacional por Amostra de Domicílios 2013. 2015. Disponível em: <http://www.ibge.gov.br/ home/estatistica/populacao/trabalhoerendimento/pnad2013>. Acesso em 22 mai. 2014.

INSTITUTO BRASILEIRO DE GEOGRAFIA E ESTATÍSTICA (IBGE). Pesquisa Nacional por Amostra de Domicílios 2014. 2016. Disponível em: <http://www.ibge.gov.br/ home/estatistica/populacao/trabalhoerendimento/pnad2014>. Acesso em 15 fev. 2016.

INSTITUTO BRASILEIRO DE OPINIÃO PÚBLICA E ESTATÍSTICA (IBOPE). ProUni é considerado ótimo por $\mathbf{8 6 \%}$ dos bolsistas. Abr. 2009. Disponível em: <http://www.ibope. com.br/inteligencia/downloads/2009/09_04_27_ibope_prouni.pdf >. Acesso em: 04 nov. 2014.

INSTITUTO DE PESQUISAS ECONÔMICAS APLICADAS (IPEA). Sistema de Indicadores de Percepção Social: Educação. Brasília: Ipea, fev. 2011. Disponível em: <http://www.ipea.gov.br/portal/images/stories/PDFs/SIPS/110228_sips_educacao.pdf>. Acesso em: 06 out. 2014. 
KOIKE, Beth. Fies e crise cortam novas matrículas em 30\%. Valor Econômico, Empresas, São Paulo, 30 set. 2015. Disponível em: <http://www.valor.com.br/empresas/4248632/fies-ecrise-cortam-novas-matriculas-em-30>. Acesso em: 13 out. 2015.

KROTON. Release de Resultados Trimestrais $-\mathbf{2}^{\mathbf{o}}$ trimestre de 2015. Disponível em: $<$ http://ri.kroton.com.br/kroton2010/web/download_arquivos.asp?id_arquivo=CB3E1C7BCC47-4D70-8DB0-515317EBEA2B>. Acesso em: 10 nov. 2015.

LACERDA, Leo Lynce Valle de. SINAES, teoria e prática: pressupostos epistemológicos em oposição. Avaliação, Campinas; Sorocaba, v. 20, n. 1, p. 87-104, mar. 2015.

LACERDA, Leo Lynce Valle de; FERRI, Cássia. Relações entre indicadores de qualidade de ensino e desempenho de estudantes dos cursos de Pedagogia do Brasil no Exame Nacional de Desempenho dos Estudantes. Revista Brasileira de Estudos Pedagógicos, Brasília, v. 96, n. 242, p. 129-145, jan./abr. 2015.

LEHER, Roberto. Para silenciar os campi. Educação \& Sociedade, Campinas, v.25, n 88 especial, p. 867-891, out. 2004.

LEHER, Roberto. Programa Universidade para Todos: democratizar ou mercantilizar? Le Monde Diplomatique Brasil, São Paulo, 01 mar. 2013. Disponível em: <http://www. diplomatique.org.br/artigo.php?id=1370>. Acesso em: 20 out. 2015.

MACHADO, Cristiane; ALAVARSE, Ocimar Munhoz. Avaliação interna no contexto das avaliações externas: desafios para a gestão escolar. Revista Brasileira de Política e Administração da Educação, Goiânia, v. 30, n. 1, p. 63-78, jan/abr. 2014.

MANCEBO, Deise; VALE, Andréa Araújo do; MARTINS, Tânia Barbosa. Políticas de expansão da educação superior no Brasil - 1995-2010. Revista Brasileira de Educação, v. 20, n. 60, p. 31-50, jan/mar. 2015

MARBACK NETO, Guilherme; FALCÃO, Izolda Rebouças. Gestão e avaliação institucional. In: EYNG, Ana Maria e GISI, Maria Lourdes (Orgs.). Políticas e Gestão da Educação Superior: desafios e perspectivas. Unijuí: Ed. Unijuí, 2007

MARINELLI, Célia Regina Gonçalves. Políticas públicas compensatórias no ensino superior brasileiro: aspectos da cidadania fragmentada. Ciências da Educação, Americana, Ano XI, $\mathrm{n}^{\circ} 21,2009$.

MARTINS, Carlos Benedito. A Reforma Universitária de 1968 e a abertura para o Ensino Superior Privado no Brasil. Educação \& Sociedade, Campinas, vol. 30, n. 106, p. 15-35, jan./abr. 2009.

MELLO NETO, Ruy de Deus e; MEDEIROS, Hugo Augusto Vasconcelos; CATANI, Afrânio Mendes. Percepções de bolsistas ProUni acerca do pertencimento ao ensino superior privado. Linhas Críticas, Brasília, v.20, n.43, p. 583-603, set./dez. 2014.

MELO, Savana Diniz Gomes; DUARTE, Adriana. Políticas para o ensino médio no Brasil: perspectivas para a universalização. Cadernos CEDES, Campinas, vol. 31, n. 84, p. 231-251, mai-ago. 2011. 
MONT'ALVÃO NETO, Arnaldo Lopo. Tendências das desigualdades de acesso ao ensino superior no Brasil: 1982-2010. Educação \& Sociedade, Campinas, vol. 35, n.127, p. 417441, abr/jun. 2014.

MORA ALFARO, Jorge. Autoevaluación con fines de acreditación y cultura de la calidad en la educación superior de Costa Rica. Avaliação, Campinas; Sorocaba, v.10, n. 03, p. 113-159, set. 2005.

MORAES, Carmen Sylvia Vidigal; ALAVARSE, Ocimar Munhoz. Ensino Médio: possibilidades de avaliação. Educação \& Sociedade, Campinas, v. 32, n. 116, p. 807-838, jul.-set. 2011.

MOROSINI, Marilia Costa. Qualidade na educação superior: tendências do século. Estudos em Avaliação Educacional, São Paulo, v.20, n. 43, p. 165-186, mai/ago. 2009.

MOURA, Maria Lucia Seidl de; FERREIRA, Maria Cristina. Projetos de Pesquisa: Elaboração, redação e apresentação. Rio de Janeiro: Ed. UERJ, 2005.

NUNES, Edson de Oliveira; FERNANDES, Ivanildo; ALBRECHT, Julia. Regulação e Ensino Superior no Brasil. Documento de Trabalho ${ }^{\circ} 112$, Observatório Universitário, Rio de Janeiro. 2014. Disponível em: <http://http://www.observatoriouniversitario.org.br/ documentos_de_trabalho/documentos_de_trabalho_112.pdf>. Acesso em: 07 ago. 2015.

OBSERVATÓRIO DO PLANO NACIONAL DE EDUCAÇÃO (PNE). Metas do PNE Indicadores (Série histórica). 2015. Disponível em: 〈http://www.observatoriodopne.org.br>. Acesso em: 11 jan. 2015.

OLIVEIRA, Ana Paula de Matos; SOUZA, Valdinei Costa; SOUSA, José Vieira de; TAVARES, Érica Pâmela Goulart. Políticas de avaliação e regulação da educação superior brasileira: percepções de coordenadores de licenciaturas no Distrito Federal. Avaliação, Campinas; Sorocaba, v. 18, n. 3, p. 629-655, nov. 2013.

OLIVEIRA, João Ferreira de; DOURADO, Luiz Fernandes; AMARAL, Nelson Cardoso; MOEHLECKE, Sabrina; CATANI, Afrânio Mendes. Políticas de acesso e expansão da educação superior: concepções e desafios. Texto para Discussão n. 23. Brasília: INEP, 2006.

OLIVEIRA, João Ferreira de; FONSECA, Marília; AMARAL, Nelson Cardoso. Avaliação, desenvolvimento institucional e qualidade do trabalho acadêmico. Educação em Revista, Curitiba, n. 28, p. 71-87, 2006.

OLIVEIRA, Romualdo Luiz Portela de. A transformação da educação em mercadoria no Brasil. Educação \& Sociedade. Campinas, vol. 30, n. 108, p. 739-760, out. 2009.

OLIVEIRA, Romualdo Luiz Portela de. A qualidade do ensino como parte do Direito à Educação: um debate em torno dos indicadores. In: FERNANDES, D. (Org.). Avaliação em Educação: olhares sobre uma prática social incontornável. Pinhais, Ed. Melo, 2011, v. 1, p. 117-134. 
PARAGUASSÚ, Lisandra. Metade dos cursos mal avaliados no Enade oferece bolsas do ProUni. O Estado de S. Paulo, Caderno Vida e Estilo, São Paulo, 31 jan. 2007. Disponível em: <http://vida-estilo.estadao.com.br/noticias/geral,metade-dos-cursos-mal-avaliados-noenade-oferece-bolsas-no-prouni,27485>. Acesso em: 19 nov. 2014.

PAULA, Maria de Fátima de. As Propostas de Democratização do Acesso ao Ensino Superior do Governo Lula: reflexões para o debate. Avaliação, Campinas, v.11, n.1, p. 133-147, mar.2006.

POCHMANN, Marcio. Estrutura social no Brasil: mudanças recentes. Serviço Social \& Sociedade, n. 104, São Paulo, p. 637-649, out./dez. 2010.

POLIDORI, Marlis Morosini. Políticas de avaliação da educação superior brasileira: Provão, SINAES, IDD, CPC, IGC e... outros índices. Avaliação, Campinas; Sorocaba, v. 14, n. 2, p. 439-452, jul. 2009.

POLIDORI, Marlis Morosini; MARINHO-ARAÚJO, Claisy Maria; BARREYRO, Gladys Beatriz. SINAES: Perspectivas e desafios na avaliação da educação superior brasileira.

Ensaio: Avaliação e Políticas Públicas em Educação, Rio de Janeiro, v.14, n.53, p. 425436, out./dez. 2006.

PROGRAMA DAS NAÇÕES UNIDAS PARA O DESENVOLVIMENTO (PNUD). Brasil sobe uma posição no ranking do IDH e fica em $7^{\circ}$ entre 187 países. 24 jun. 2014.

Disponível em: <http://www.pnud.org.br/Noticia.aspx?id=3909>. Acesso em: 11 dez. 2014.

RIBEIRO, Eliane. O ProUni e as disputas em torno da democratização do ensino superior. Le Monde Diplomatique Brasil, São Paulo, n68, p. 31, Mar. 2013. Disponível em: <http:// www.diplomatique.org.br/artigo.php?id=1385>. Acesso em: 07 jan. 2014.

RISTOFF, Dilvo. Perfil Socioeconômico do estudante de graduação: uma análise de dois ciclos completos do ENADE (2004 a 2009). Cadernos do GEA, Rio de Janeiro, n. 4, p. 2-24, jul./dez. 2013.

RISTOFF, Dilvo. O novo perfil do campus brasileiro: uma análise do perfil socioeconômico do estudante de graduação. Avaliação, Campinas; Sorocaba, vol.19, n.3, pp. 723-747, nov. 2014.

ROCHA, Marisa Brandão. Metamorfose dos Cursos Superiores de Tecnologia no Brasil: política de acesso ao ensino superior em um estado burguês. Tese (Doutorado) - Faculdade de Educação, Universidade Federal Fluminense, Niterói, 2009.

ROSSATO, Ermelio. A expansão do ensino superior no Brasil: do domínio público à privatização. Passo Fundo: Ed. UPF, 2006.

ROTHEN, José Carlos; BARREYRO, Gladys Beatriz. Avaliação da educação superior no segundo governo Lula: "Provão II" ou reedição de velhas práticas? Educação \& Sociedade, Campinas, v. 32, n 114, p. 21-38, jan/mar. 2011.

SANTOS, Boaventura de Sousa. A Universidade no Século XXI: para uma reforma democrática e emancipatória da Universidade. São Paulo: Cortez, 2011. 
SARFATI, Gilberto. SHWARTZBAUM, Alan. Sinergias nas fusões e aquisições do setor de educação superior no Brasil. Revista Pensamento Contemporâneo em Administração, Rio de Janeiro, v. 7, n. 4, p. 1-23, out/dez 2013.

SCHULTZ, Theodore William. O capital humano: investimentos em educação e pesquisa. Rio de Janeiro: Zahar, 1973.

SCHWARTZMAN, Simon. O "conceito preliminar" e as boas práticas de avaliação do ensino superior. Revista da Associação Brasileira de Mantenedoras de Ensino Superior, Brasília, n. 38, p. 9-32, dez. 2008.

SÉCCA, Rodrigo Ximenes; LEAL, Rodrigo Mendes. Análise do setor de ensino superior privado no Brasil. BNDES Setorial 30. Rio de Janeiro: BNDES, set. 2009.

SGUISSARDI, Valdemar. Que lugar ocupa a qualidade nas recentes políticas de educação superior?. Avaliação, Campinas; Sorocaba, v. 11, n. 03, p. 69-89, set. 2006.

SGUISSARDI, Valdemar. Modelo de expansão da educação superior no Brasil: predomínio privado/mercantil e desafios para a regulação e a formação universitária. Educação \& Sociedade, Campinas, v. 29, n. 105, p. 991-1022, set./dez. 2008.

SGUISSARDI, Valdemar. Estudo diagnóstico da política de expansão da (e acesso à) educação superior no Brasil - 2002-2012. Brasília: Edital n. 051/2014 - SESU; Projeto de Organismo Internacional - OEI; Projeto OEI/BRA/10/002, 2014.

SILVA JÚNIOR, João dos Reis; SGUISSARDI, Valdemar. As novas faces da Educação Superior no Brasil: reforma do Estado e mudanças na produção. São Paulo: Cortez, 2001.

SOUSA, José Vieira de. O ensino superior privado no Distrito Federal: uma análise de sua recente expansão (1995-2001). Tese (Doutorado), Programa de Pós-Graduação em Sociologia, Universidade de Brasília, Brasília, 2003.

SOUSA, José Vieira de. Aumento de vagas ociosas na educação superior brasileira (20032008): redução do poder indutor da expansão via setor privado?. In: $33^{a}$ REUNIÃO ANUAL DA ANPEd, 2010, Caxambu. Anais da 33 ${ }^{\text {a }}$ Reunião da ANPEd. Caxambu: ANPEd, 2010. Disponível em: <http://www.anped11.uerj.br/AUMENTO DEVAGAS.pdf>. Acesso em: 15 ago. 2015

SOUSA, José Vieira de. Qualidade na Educação Superior: lugar e sentido na relação públicoprivado. Cadernos CEDES, Campinas, vol. 29, n. 78, p. 242-256, maio/ago. 2009.

TEIXEIRA, Anísio. Meia vitória, mas vitória. Revista Brasileira de Estudos Pedagógicos. Rio de Janeiro, v. 37, n. 86, p. 222-223, abr./jun. 1962.

TOLEDO, Luiz Fernando; SALDAÑA, Paulo. Bolsista integral do ProUni tem notas mais altas no Enade. O Estado de S. Paulo, Caderno Educação. São Paulo, 02 nov. 2014.

Disponível em: <http://educacao.estadao.com.br/noticias/geral,bolsista-integral-do-prounitem-nota-mais-alta-no-enade,1586702>. Acesso em: 17 nov. 2014. 
TROW, Martin. Reflections on the transition from elite to mass to universal access: forms and phases of higher education in modern societies since WWII. Berkeley: University of California, 2005. Disponível em: <http://repositories.cdlib.org/igs/ WP2005-4>. Acesso em: 13 mai. 2014. 


\begin{abstract}
ANEXOS
Anexo A - Áreas e cursos de graduação avaliados pelo ENADE (2004-2014)

Anexo B - Questionários do Estudante do ENADE de 2012 e 2013

Anexo C - Nota Técnica sobre o cálculo do Indicador de Diferença entre os Desempenhos

Observado e Esperado (IDD) 2012
\end{abstract}


Anexo A - Áreas e cursos de graduação avaliados pelo ENADE (2004-2014)

Fonte: BRASIL, 2015e.

Em 2004: Agronomia, Educação Física, Enfermagem, Farmácia, Fisioterapia, Fonoaudiologia, Medicina, Medicina Veterinária, Nutrição, Odontologia, Serviço Social, Terapia Ocupacional e Zootecnia.

Em 2005: Arquitetura e Urbanismo, Biologia, Ciências Sociais, Computação, Engenharia (em oito grupos), Filosofia, Física, Geografia, História, Letras, Matemática, Pedagogia e Química. Em 2006: Administração, Arquivologia, Biblioteconomia, Biomedicina, Ciências Contábeis, Ciências Econômicas, Comunicação Social, Design, Direito, Formação de Professores (Normal Superior), Música, Psicologia, Secretariado Executivo, Teatro e Turismo.

Em 2007: Agronomia, Biomedicina, Educação Física, Enfermagem, Farmácia, Fisioterapia, Fonoaudiologia, Medicina, Medicina Veterinária, Nutrição, Odontologia, Serviço Social, Tecnologia em Agroindústria, Tecnologia em Radiologia, Terapia Ocupacional e Zootecnia.

Em 2008: Arquitetura e Urbanismo, Biologia, Ciências Sociais, Computação, Engenharia, Filosofia, Física, Geografia, História, Letras, Matemática, Pedagogia e Química, e os Cursos Superiores de Tecnologia em Construção de Edifícios, Alimentos, Automação Industrial, Gestão da Produção Industrial, Manutenção Industrial, Processos Químicos, Fabricação Mecânica, Análise e Desenvolvimento de Sistemas, Redes de Computadores e Saneamento Ambiental.

Em 2009: Administração, Arquivologia, Biblioteconomia, Ciências Contábeis, Ciências Econômicas, Comunicação Social, Design, Direito, Estatística, Música, Psicologia, Relações Internacionais, Secretariado Executivo, Teatro e Turismo; e os Cursos Superiores de Tecnologia em: Design de Moda, Gastronomia, Gestão de Recursos Humanos, Gestão de Turismo, Gestão Financeira, Marketing e Processos Gerenciais.

Em 2010: Agronomia, Biomedicina, Educação Física, Enfermagem, Farmácia, Fisioterapia, Fonoaudiologia, Medicina, Medicina Veterinária, Nutrição, Odontologia, Serviço Social, Terapia Ocupacional e Zootecnia; e os cursos que conferem diploma de tecnólogo em Agroindústria, Agronegócios, Gestão Hospitalar, Gestão Ambiental e Radiologia.

Em 2011: Cursos que conferem diploma de bacharel em Arquitetura e Urbanismo e Engenharia; cursos que conferem diploma de bacharel ou licenciatura em Biologia, Ciências Sociais, Computação, Filosofia, Física, Geografia, História, Letras, Matemática e Química; cursos que conferem diploma de licenciatura em Pedagogia, Educação Física, Artes Visuais e 
Música; e cursos que conferem diploma de tecnólogo em Alimentos, Construção de Edifícios, Automação Industrial, Gestão da Produção Industrial, Manutenção Industrial, Processos Químicos, Fabricação Mecânica, Análise e Desenvolvimento de Sistemas, Redes de Computadores e Saneamento Ambiental.

Em 2012: Cursos que conferem diploma de bacharel em: Administração; Ciências Contábeis; Ciências Econômicas; Comunicação Social; Design; Direito; Psicologia; Relações Internacionais; Secretariado Executivo; Turismo; que conferem diploma de tecnólogo em: Gestão Comercial; Gestão de Recursos Humanos; Gestão Financeira; Logística; Marketing; Processos Gerenciais.

Em 2013: Cursos que conferem diploma de bacharel em: Agronomia, Biomedicina, Educação Física, Enfermagem, Farmácia, Fisioterapia, Fonoaudiologia, Medicina, Medicina Veterinária, Nutrição, Odontologia, Serviço Social e Zootecnia; que conferem diploma de tecnólogo em: Agronegócio, Gestão Hospitalar, Gestão Ambiental e Radiologia.

Em 2014: cursos que: conferem diploma de bacharel em Arquitetura e Urbanismo; Sistema de Informação; Engenharia Civil; Engenharia Elétrica; Engenharia de Computação; Engenharia de Controle e Automação; Engenharia Mecânica; Engenharia Química; Engenharia de Alimentos; Engenharia de Produção; Engenharia Ambiental; Engenharia Florestal; e Engenharia.

Conferem diploma de bacharel ou licenciatura em Ciência da Computação; Ciências Biológicas; Ciências Sociais; Filosofia; Física; Geografia; História; Letras-Português; Matemática; e Química.

Conferem diploma de licenciatura em Artes Visuais; Educação Física; Letras-Português e Espanhol; Letras-Português e Inglês; Música; e Pedagogia.

Conferem diploma de tecnólogo em Análise e Desenvolvimento de Sistemas; Automação Industrial; Gestão da Produção Industrial; e Redes de Computadores. 
Anexo B - Questionários do Estudante do ENADE de 2012 e 2013

Fonte: BRASIL, 2015e

Questionário do Estudante 2012

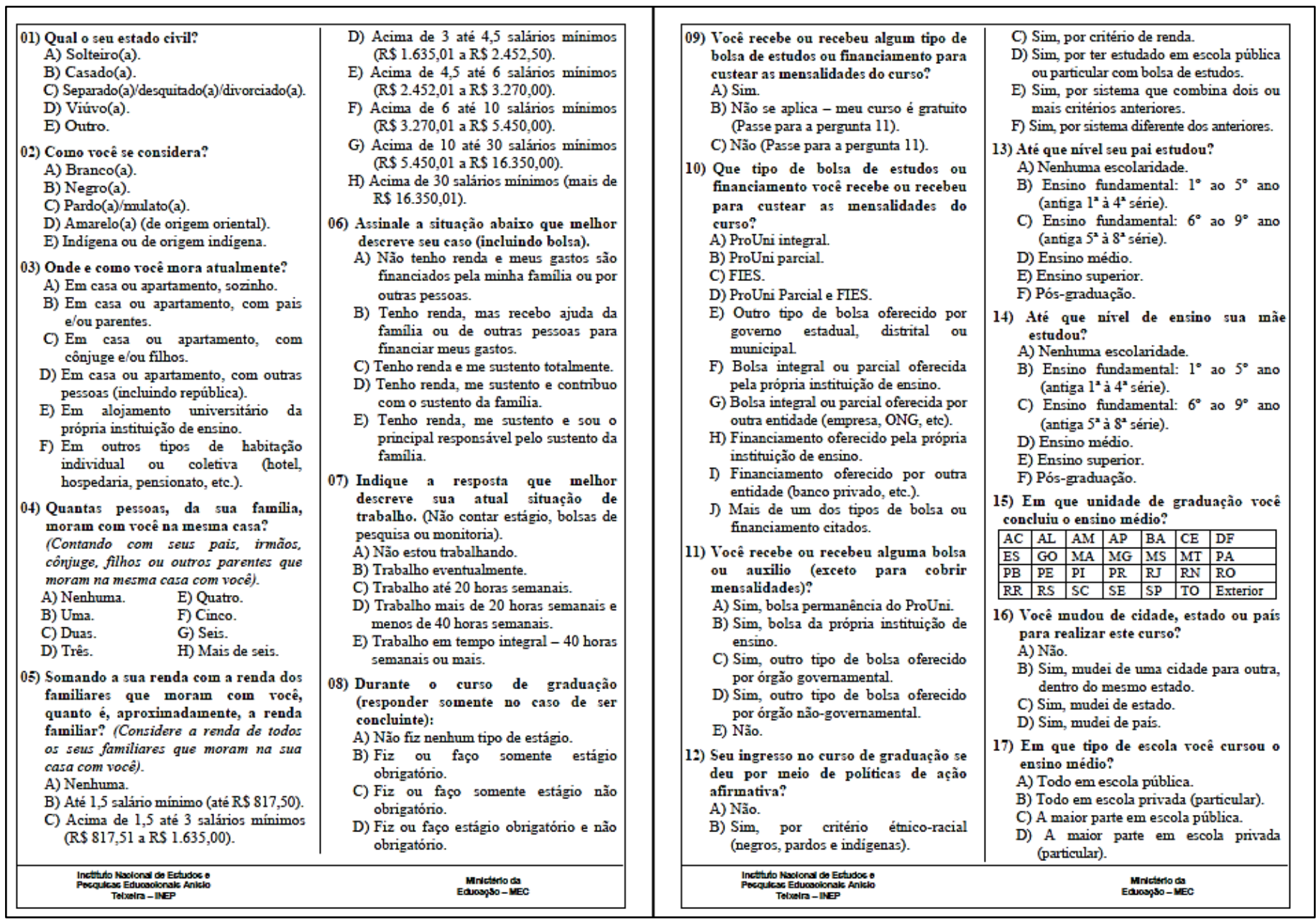


Questionário do Estudante 2012 (cont.)

\begin{tabular}{|c|c|c|c|}
\hline 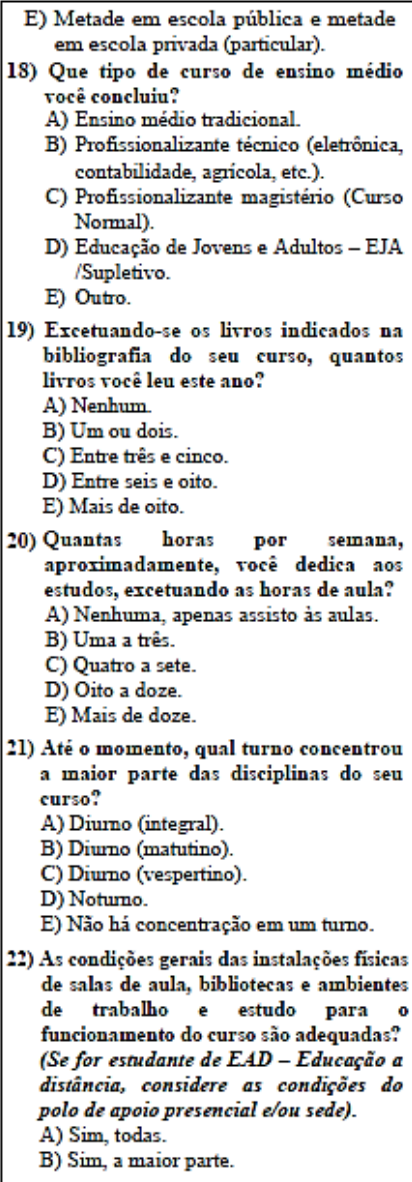 & 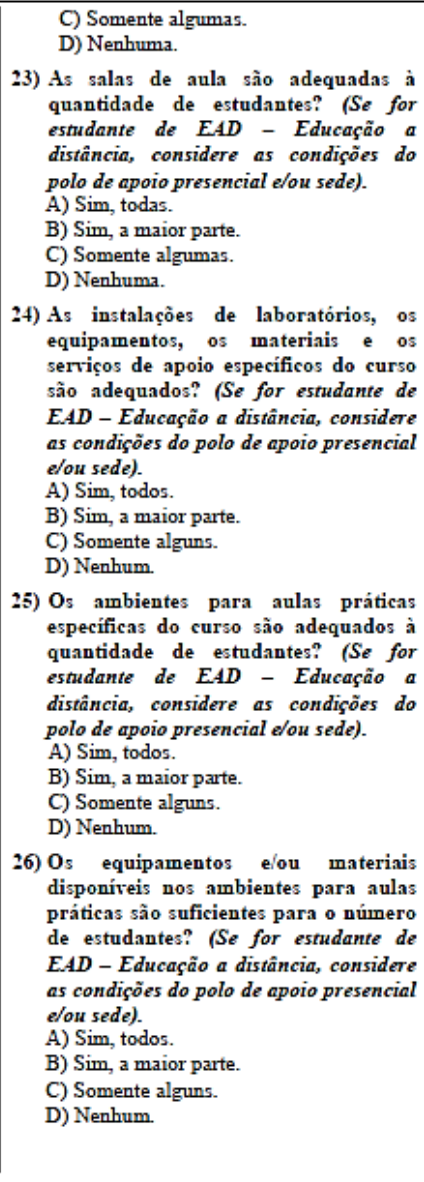 & 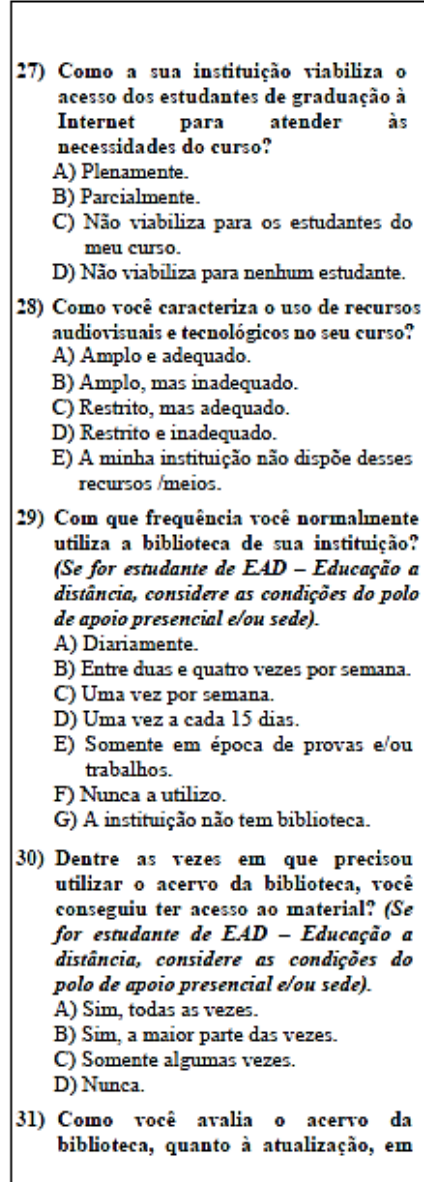 & 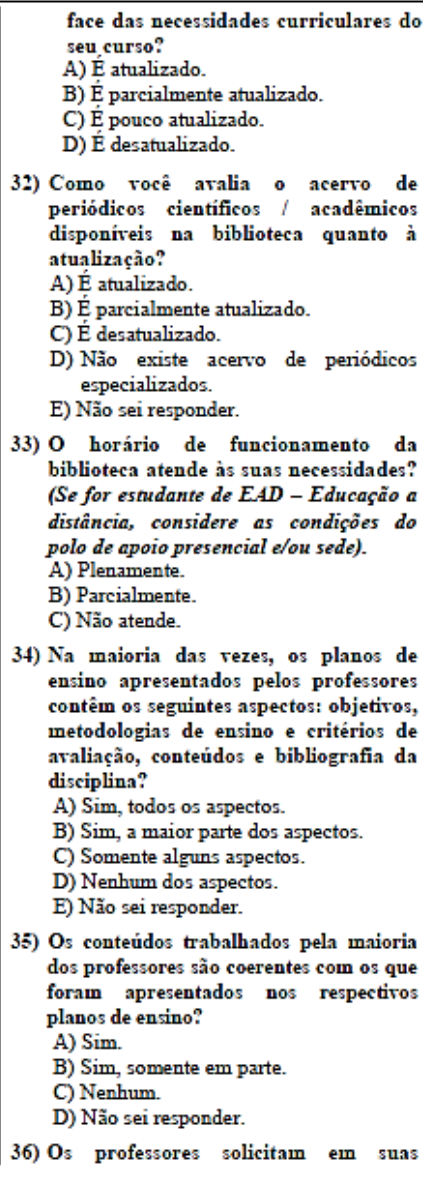 \\
\hline 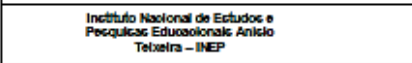 & 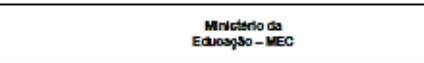 & 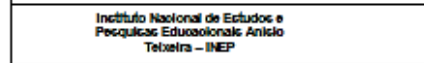 & 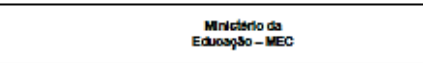 \\
\hline
\end{tabular}


Questionário do Estudante 2012 (cont.)

\begin{tabular}{|c|c|c|c|}
\hline 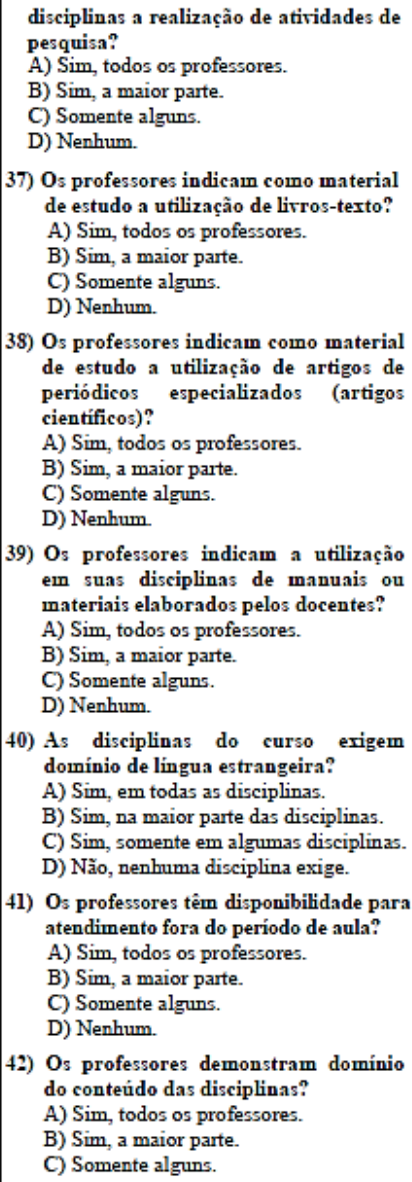 & 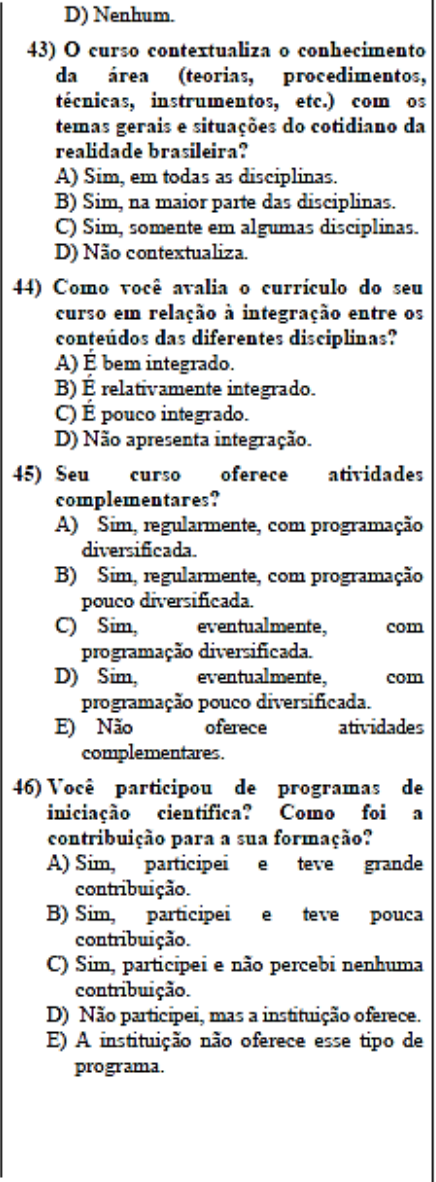 & 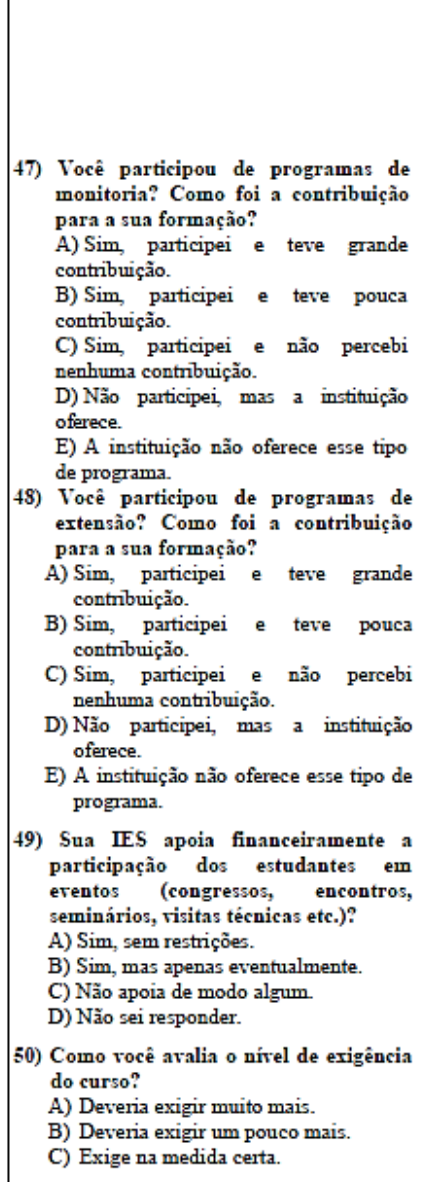 & 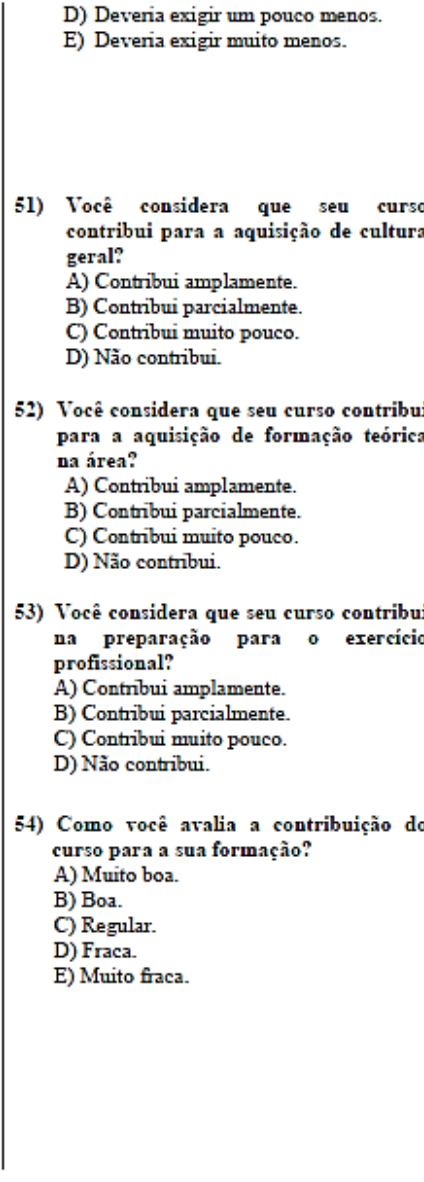 \\
\hline 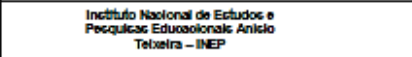 & 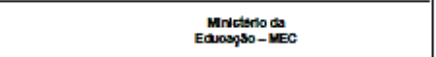 & 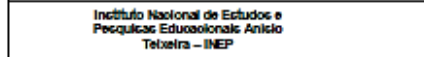 & 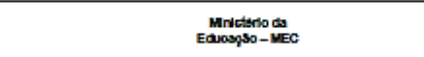 \\
\hline
\end{tabular}


Questionário do Estudante 2013

\begin{tabular}{|c|c|}
\hline 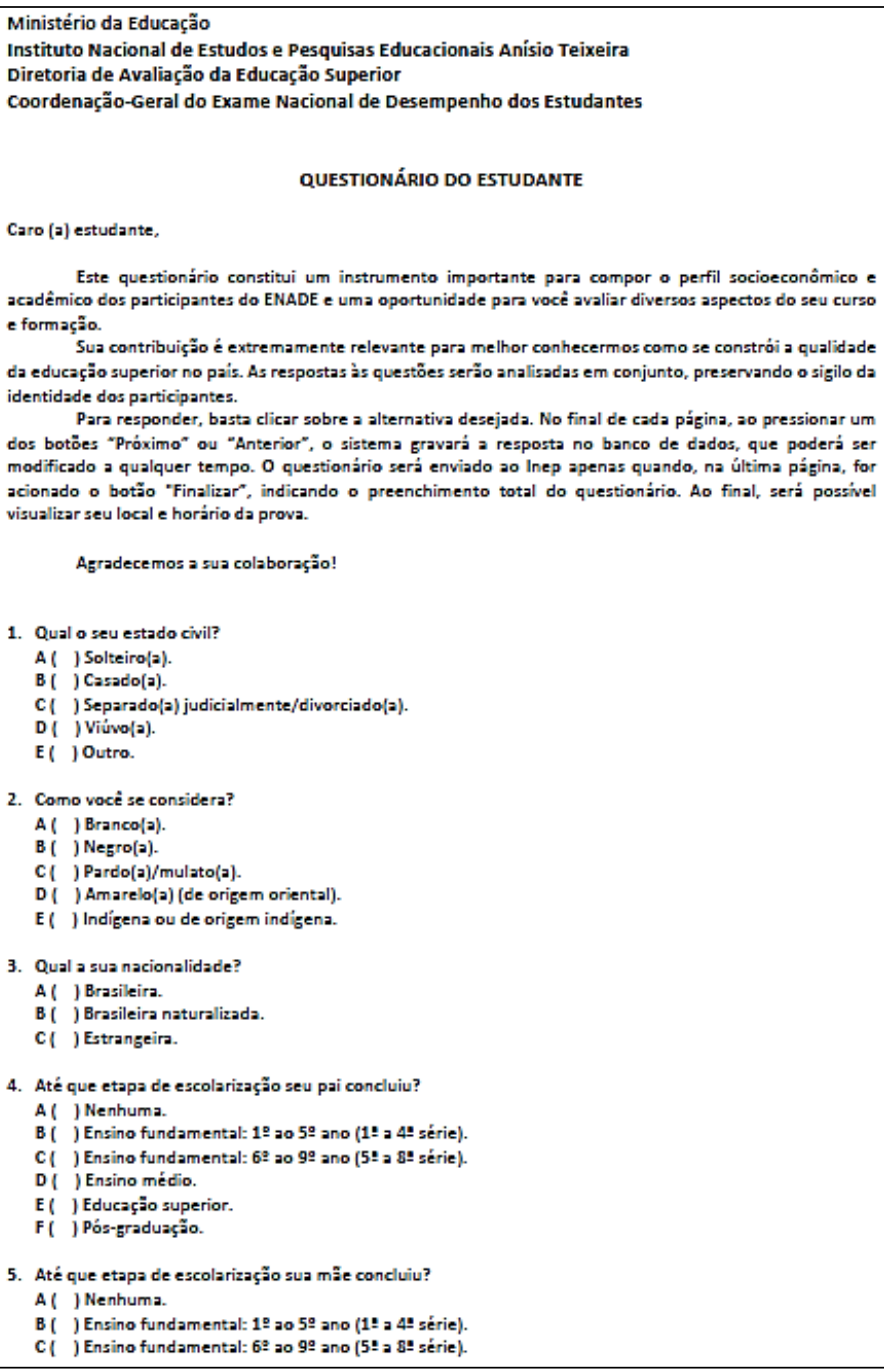 & 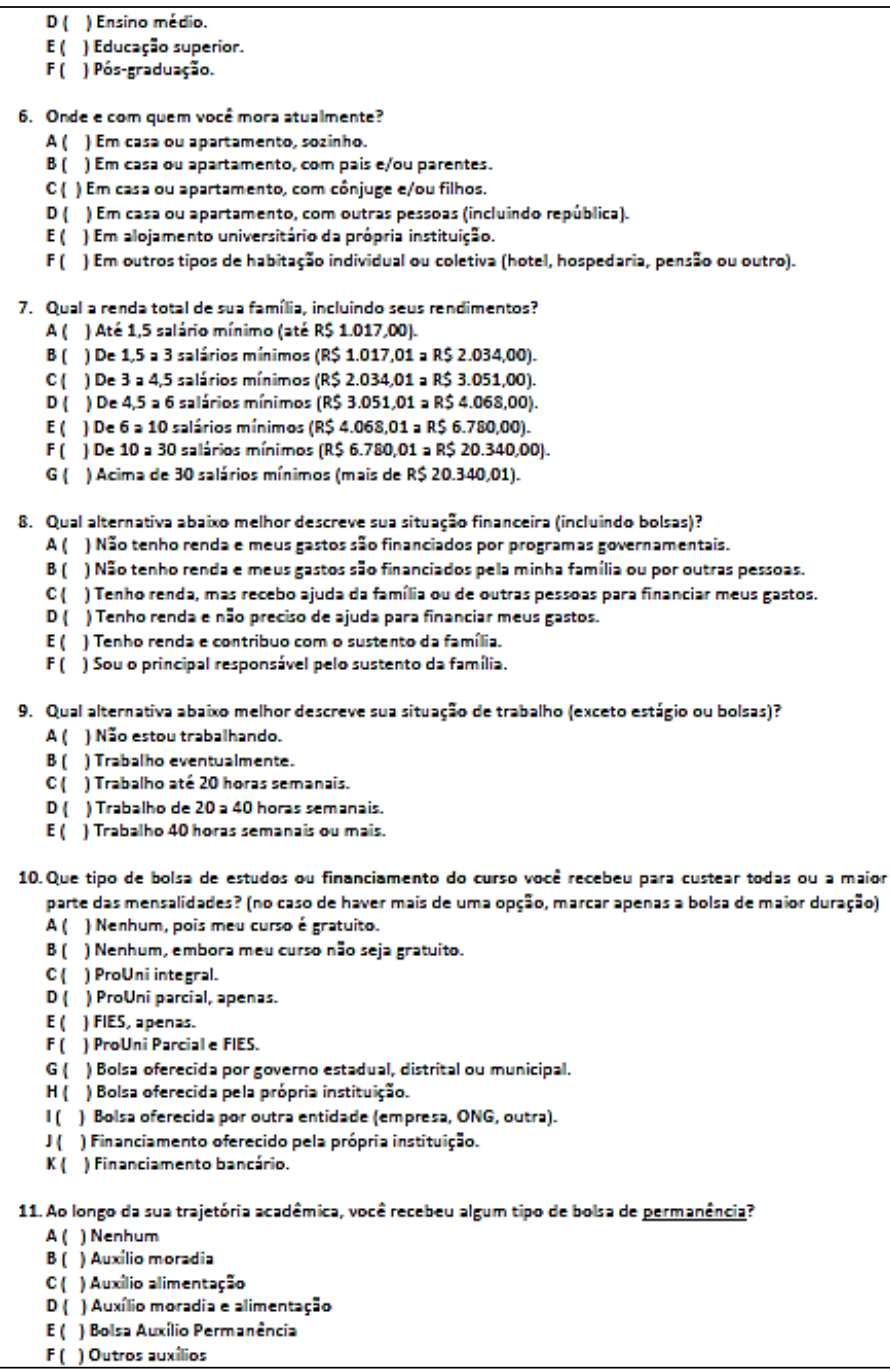 \\
\hline
\end{tabular}


Questionário do Estudante 2013 (cont.)

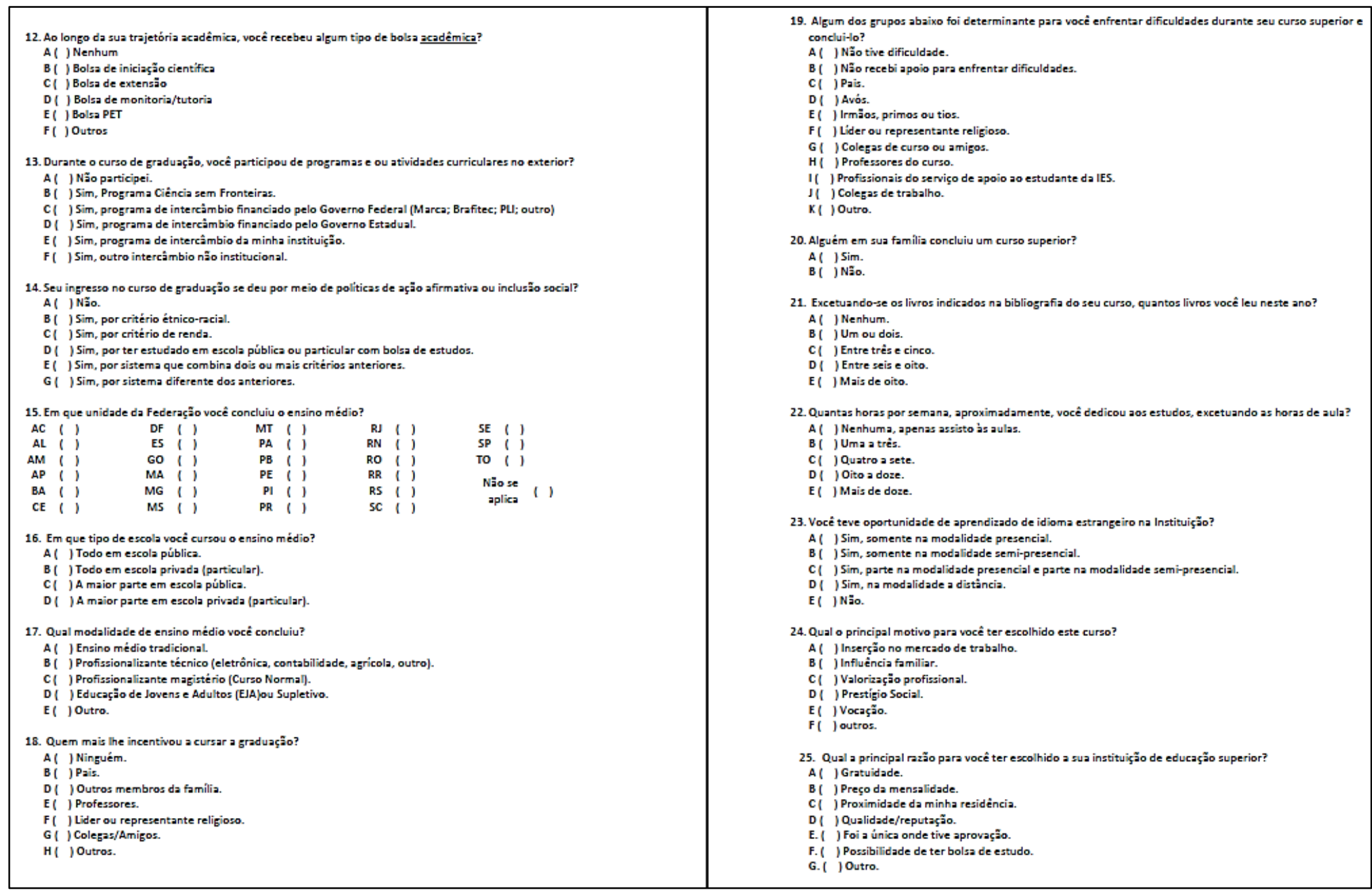


Questionário do Estudante 2013 (cont.)

\begin{tabular}{|c|c|c|c|c|c|c|c|}
\hline \multicolumn{8}{|c|}{$\begin{array}{l}\text { A seguir, leia cuidadosamente cada assertiva e indique seu grau de concordância com cada uma delas, segundo a escala que varia de } 1 \text { (discordância total) a } \\
\text { (concordância total). Caso você julgue näo ter elementos para avaliar a assertiva ou quando considerar não pertinente ao seu curso, assinale a opçăo "Näo se aplica/Nã } \\
\text { sei responder". }\end{array}$} \\
\hline ORGANIZAÇĂO DIDÁTICO-PEDAGÓGICA & $\begin{array}{l}10 \text { Discordo } \\
\text { Totalmente }\end{array}$ & 20 & 30 & 40 & 50 & $\begin{array}{l}60 \text { Concordo } \\
\text { Totalmente }\end{array}$ & \\
\hline $\begin{array}{l}\text { 26. As disciplinas curzadas contribuiram para sua formação } \\
\text { integral, como cidadão e profissional. }\end{array}$ & 10 & 20 & 30 & 40 & 50 & 60 & $\begin{array}{l}\text { () Nä̀ sei responder } \\
\text { () Näo se aplica }\end{array}$ \\
\hline $\begin{array}{l}\text { 27. Os conteúdos abordados nas disciplinas do curso } \\
\text { favoreceram sua atuaçấo em eatágios ou em atividades de } \\
\text { iniciaçâo profissional. }\end{array}$ & 10 & 20 & 30 & 40 & 50 & 60 & $\begin{array}{l}\text { ( ) Näo sei responder } \\
\text { (]) Näo se aplica }\end{array}$ \\
\hline $\begin{array}{l}\text { 28. As metodologias de ensino utilizadas no curso desafiaram } \\
\text { vocé a aprofundar conhecimentos e desenvolver } \\
\text { competências reflexivas e criticas. }\end{array}$ & 10 & 20 & 30 & 40 & 50 & 60 & $\begin{array}{l}\text { () Nä̃o sei responder } \\
\text { () Näo se aplica }\end{array}$ \\
\hline 29. O curso propiciou experiências de aprendizagem inovadoras. & 10 & 20 & 30 & 40 & 50 & 60 & $\begin{array}{l}\text { ( ) Näo sei responder } \\
\text { () Näo se aplica }\end{array}$ \\
\hline $\begin{array}{l}\text { 30. O curso contribuiu para o desenvolvimento da sua } \\
\text { congciência ética para o exercicio profissional. }\end{array}$ & 10 & 20 & 30 & 40 & 50 & 60 & $\begin{array}{l}\text { ( ) Näo sei responder } \\
\text { ( ) Näo se aplica }\end{array}$ \\
\hline $\begin{array}{l}\text { 31. No curso você teve oportunidade de aprender a trabalhar em } \\
\text { equipe. }\end{array}$ & 10 & 20 & 30 & 40 & 50 & 60 & $\begin{array}{l}\text { ( ) Näo sei responder } \\
\text { () Näo se aplica }\end{array}$ \\
\hline $\begin{array}{l}\text { 32. O curso possibilitou aumentar sua capacidade de reflexäo e } \\
\text { argumentação. }\end{array}$ & 10 & 20 & 30 & 40 & 50 & 60 & $\begin{array}{l}\text { ( ) Näo sei responder } \\
\text { () Näo se aplica }\end{array}$ \\
\hline $\begin{array}{l}\text { 33. O curso promoveu o desenvolvimento da sua capacidade de } \\
\text { pensar criticamente, analisar e refletir sobre soluçöes para } \\
\text { problemas da sociedade. }\end{array}$ & 10 & 20 & 30 & 40 & 50 & 60 & $\begin{array}{l}\text { () Näo sei responder } \\
\text { () Näo se aplica }\end{array}$ \\
\hline $\begin{array}{l}\text { 34. O curso contribuiu para você ampliar sua capacidade de } \\
\text { comunicação nas formas oral e eacrita. }\end{array}$ & 10 & 20 & 30 & 40 & 50 & 60 & $\begin{array}{l}\text { ( ) Näo sei responder } \\
\text { () Näo se aplica }\end{array}$ \\
\hline $\begin{array}{l}\text { 35. o curso contribuiu para } \circ \text { desenvolvimento da sua } \\
\text { capacidade de aprender e atualizar-se permanentemente. }\end{array}$ & 10 & 20 & 30 & 40 & 50 & 60 & $\begin{array}{l}\text { ( ) Näo sei responder } \\
\text { (]) Näo se aplica }\end{array}$ \\
\hline $\begin{array}{l}\text { 36. As relaçōes professor-aluno ao longo do curso estimularam } \\
\text { vocé a estudar e aprender. }\end{array}$ & 10 & 20 & 30 & 40 & 50 & 60 & $\begin{array}{l}\text { ( ) Näo sei responder } \\
\text { (]) Näo se aplica }\end{array}$ \\
\hline $\begin{array}{l}\text { 37. Os planos de ensino apresentados pelos professores } \\
\text { contribuiram para seus estudos. }\end{array}$ & 10 & 20 & 30 & 40 & 50 & 60 & $\begin{array}{l}\text { ( ) Não sei responder } \\
\text { () Näo se aplica }\end{array}$ \\
\hline
\end{tabular}


Questionário do Estudante 2013 (cont.)

\begin{tabular}{|c|c|c|c|c|c|c|c|}
\hline $\begin{array}{l}\text { 38. As referências bibliográficas indicadas pelos professores nos } \\
\text { planos de ensino contribuíram para seus estudos e } \\
\text { aprendizagens. }\end{array}$ & 10 & 20 & 30 & 40 & 50 & 60 & $\begin{array}{l}\text { () Näo sei responder } \\
\text { () Nä̀ se aplica }\end{array}$ \\
\hline $\begin{array}{l}\text { 39. Foram oferecidas oportunidades para os estudantes } \\
\text { superarem problemas e dificuldades relacionados ao } \\
\text { processo de formaçäo. }\end{array}$ & 10 & 20 & 30 & 40 & 50 & 60 & $\begin{array}{l}\text { () Näo sei responder } \\
\text { () Näo se aplica }\end{array}$ \\
\hline $\begin{array}{l}\text { 40. A coordenação do curso promoveu açôes de mediação em } \\
\text { situaçöes eventuais de conflito ocorridas na relaçấo } \\
\text { professor-aluno. }\end{array}$ & 10 & 20 & 30 & 40 & 50 & 60 & $\begin{array}{l}\text { () Näo sei responder } \\
\text { () Näo se aplica }\end{array}$ \\
\hline $\begin{array}{l}\text { 41. } 0 \text { curso exigiu de vocé organização e dedicação frequente aos } \\
\text { estudos. }\end{array}$ & 10 & 20 & 30 & $4 \bigcirc$ & 50 & 60 & $\begin{array}{l}\text { () Nä̀ sei responder } \\
\text { () Nä̀ se aplica }\end{array}$ \\
\hline $\begin{array}{l}\text { 42. Foram oferecidas oportunidades para os estudantes } \\
\text { participarem de programas, projetos ou atividades de } \\
\text { extensão universitária. }\end{array}$ & 10 & 20 & 30 & 40 & 50 & 60 & $\begin{array}{l}\text { () Näo sei responder } \\
\text { () Näo se aplica }\end{array}$ \\
\hline $\begin{array}{l}\text { 43. Foram oferecidas oportunidades para os estudantes } \\
\text { participarem de projetos de iniciação cientifica e de } \\
\text { atividades que estimularam a investigação académica. }\end{array}$ & 10 & 20 & 30 & 40 & 50 & 60 & $\begin{array}{l}\text { () Näo sei responder } \\
\text { () Näo se aplica }\end{array}$ \\
\hline $\begin{array}{l}\text { 44. O curso ofereceu condições para os estudantes participarem } \\
\text { de eventos internos e/ou externos à instituiçẫo. }\end{array}$ & 10 & 20 & 30 & $4 \bigcirc$ & 50 & 60 & $\begin{array}{l}\text { (1) Nä̀ sei responder } \\
\text { () Näo se aplica }\end{array}$ \\
\hline $\begin{array}{l}\text { 45. A instituiçăo ofereceu oportunidades para os estudantes } \\
\text { atuarem como representantes em órgäos colegiados. }\end{array}$ & 10 & 20 & 30 & $4 \bigcirc$ & 50 & 60 & $\begin{array}{l}\text { () Näo sei responder } \\
\text { () Näo se aplica }\end{array}$ \\
\hline $\begin{array}{l}\text { 46. O curso favoreceu a articulação do conhecimento teórico } \\
\text { com atividades práticas. }\end{array}$ & 10 & 20 & 30 & 40 & 50 & 60 & $\begin{array}{l}\text { () Nä̀ sei responder } \\
\text { (1) Näo se aplica }\end{array}$ \\
\hline $\begin{array}{l}\text { 47. As atividades práticas foram suficientes para a formação } \\
\text { profissional. }\end{array}$ & 10 & 20 & 30 & 40 & 50 & 60 & $\begin{array}{l}\text { () Näo sei responder } \\
\text { () Nä̀ se aplica }\end{array}$ \\
\hline 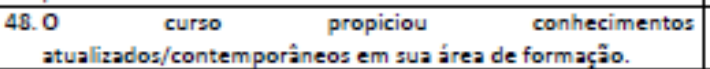 & 10 & 20 & 30 & 40 & 50 & 60 & $\begin{array}{l}\text { () Näo sei responder } \\
\text { () Näo se aplica }\end{array}$ \\
\hline $\begin{array}{l}\text { 49. o estágio supervisionado proporcionou experiências } \\
\text { diversificadas para a sua formaçẫo. }\end{array}$ & 10 & 20 & 30 & $4 \bigcirc$ & 50 & 60 & $\begin{array}{l}\text { () Nä̀ sei responder } \\
\text { () Nä̀ se aplica }\end{array}$ \\
\hline $\begin{array}{l}\text { 50. As atividades realizadas durante seu trabalho de conclusão de } \\
\text { curso contribuiram para qualificar sua formação profissional }\end{array}$ & 10 & 20 & 30 & $4 \bigcirc$ & 50 & 60 & $\begin{array}{l}\text { () Näo sei responder } \\
\text { (1) Näo se aplica }\end{array}$ \\
\hline $\begin{array}{l}\text { 51. Foram oferecidas oportunidades para os estudantes } \\
\text { realizarem intercâmbios e/ou estágios no pais. }\end{array}$ & 10 & 20 & 30 & 40 & 50 & 60 & $\begin{array}{l}\text { () Nä̀ sei responder } \\
\text { (1) Näo se aplica }\end{array}$ \\
\hline $\begin{array}{l}\text { 52. Foram oferecidas oportunidades para os estudantes } \\
\text { realizarem intercâmbios e/ou estágios fora do país. }\end{array}$ & 10 & 20 & 30 & $4 \bigcirc$ & 50 & 60 & $\begin{array}{l}\text { (1) Näo sei responder } \\
\text { () Näo se aplica }\end{array}$ \\
\hline
\end{tabular}


Questionário do Estudante 2013 (cont.)

\begin{tabular}{|c|c|c|c|c|c|c|c|}
\hline $\begin{array}{l}\text { 53. O curso realizou avaliações periódicas da qualidade das } \\
\text { disciplinas e da atuação dos professores. }\end{array}$ & 10 & 20 & 30 & 40 & 50 & 60 & \begin{tabular}{|l} 
() ) Näo sei responder \\
(1) Näo se aplica
\end{tabular} \\
\hline $\begin{array}{l}\text { 54. As avaliações de aprendizasem aplicadas pelos professores } \\
\text { foram coerentes com o conteúdo ministrado. }\end{array}$ & 10 & 20 & 30 & $4 \bigcirc$ & 50 & 60 & $\begin{array}{l}\text { () Nä̀ sei responder } \\
\text { () Näo se aplica }\end{array}$ \\
\hline $\begin{array}{l}\text { 55. Os professores apresentaram disponibilidade para atender os } \\
\text { estudantes. }\end{array}$ & 10 & 20 & 30 & 40 & 50 & 60 & $\begin{array}{l}\text { ( ) Näo sei responder } \\
\text { ( ) Näo se aplica } \\
\end{array}$ \\
\hline $\begin{array}{l}\text { 56. Os professores demonstraram domínio do conteúdo das } \\
\text { disciplinas que ministraram. }\end{array}$ & 10 & 20 & 30 & 40 & 50 & 60 & $\begin{array}{l}\text { () Näo sei responder } \\
\text { () Näo se aplica }\end{array}$ \\
\hline $\begin{array}{l}\text { 57. Os professores utilizaram tecnologias de informaçã̃o e } \\
\text { comunicação (TICs) no processo de ensino-aprendizagem. }\end{array}$ & 10 & 20 & 30 & 40 & 50 & 60 & $\begin{array}{l}\text { ( ) Näo sei responder } \\
\text { ( ) Näo se aplica }\end{array}$ \\
\hline $\begin{array}{l}\text { 58. A instituição dispốs de quantidade suficiente de funcionários } \\
\text { para o apoio administrativo e acadêmico. }\end{array}$ & 10 & 20 & 30 & 40 & 50 & 60 & $\begin{array}{l}\text { ( ) Näo sei responder } \\
\text { () Näo se aplica }\end{array}$ \\
\hline $\begin{array}{l}\text { 59. O curso disponibilizou monitores ou tutores para auxiliar os } \\
\text { estudantes. }\end{array}$ & 10 & 20 & 30 & 40 & 50 & 60 & $\begin{array}{l}\text { ( ) Näo sei responder } \\
\text { () Näo se aplica }\end{array}$ \\
\hline $\begin{array}{l}\text { 60. As condiçôes de infraestrutura das salas de aula foram } \\
\text { adequadas. }\end{array}$ & 10 & 20 & 30 & 40 & 50 & 60 & $\begin{array}{l}\text { () Näo sei responder } \\
\text { () Näo se aplica }\end{array}$ \\
\hline $\begin{array}{c}\text { 61. Os equipamentos e materiais disponiveis para as aulas } \\
\text { práticas foram adequados para a quantidade de estudantes. }\end{array}$ & 10 & 20 & 30 & 40 & 50 & 60 & $\begin{array}{l}\text { () Näo sei responder } \\
\text { () Näo se aplica }\end{array}$ \\
\hline $\begin{array}{l}\text { 62. Os ambientes e equipamentos deatinados às aulas práticas } \\
\text { foram adequados ao curso. }\end{array}$ & 10 & 20 & 30 & 40 & 50 & 60 & $\begin{array}{l}\text { () Näo sei responder } \\
\text { ( ) Näo se aplica }\end{array}$ \\
\hline $\begin{array}{l}\text { 63. A biblioteca dispós das referéncias bibliográficas que os } \\
\text { estudantes necessitaram. }\end{array}$ & 10 & 20 & 30 & 40 & 50 & 60 & $\begin{array}{l}\text { ( ) Näo sei responder } \\
\text { () Näo se aplica }\end{array}$ \\
\hline $\begin{array}{l}\text { 64. A instituição contou com biblioteca virtual ou conferiu acesso } \\
\text { a obras disponiveis em acervos virtuais. }\end{array}$ & 10 & 20 & 30 & 40 & 50 & 60 & $\begin{array}{l}\text { ( ) Näo sei responder } \\
\text { () Näo se aplica }\end{array}$ \\
\hline $\begin{array}{l}\text { 65. O ambiente acadêmico favoreceu a reflexäo e convivência } \\
\text { social de forma a promover um clima de respeito à } \\
\text { diversidade. }\end{array}$ & 10 & 20 & 30 & 40 & 50 & 60 & $\begin{array}{l}\text { (1) Näo sei responder } \\
\text { () Näo se aplica }\end{array}$ \\
\hline $\begin{array}{l}\text { 66. A instituição contou com espaços de cultura, de lazer, de } \\
\text { convívio e interaçăo social. }\end{array}$ & 10 & 20 & 30 & 40 & 50 & 60 & $\begin{array}{l}\text { ( ) Näo sei responder } \\
\text { ( ) Näo se aplica }\end{array}$ \\
\hline $\begin{array}{l}\text { 67. A instituição dispôs de refeitório, cantina e banheiros em } \\
\text { condiçoses adequadas que atenderam as necessidades dos } \\
\text { seus usuários. }\end{array}$ & 10 & 20 & 30 & $4 \bigcirc$ & 50 & 60 & $\begin{array}{l}\text { () Näo sei responder } \\
\text { ( ) Näo se aplica }\end{array}$ \\
\hline
\end{tabular}


Anexo C - Nota Técnica sobre o cálculo do Indicador de Diferença entre os Desempenhos

Observado e Esperado (IDD) 2012.

Fonte: INEP, 2013a, p. 18-22

\subsection{Nota do Indicador de Diferença entre os Desempenhos Observado e Esperado}

(NIDD)

Sabe-se que a diferença entre os desempenhos no Enade de estudantes egressos de dois cursos de graduação de duas Instituições distintas não depende somente das diferenças de qualidade entre esses cursos. As diferenças em relação ao perfil dos estudantes de ambos os cursos ao ingressar no Ensino Superior também influenciam as diferenças nos resultados.

O Indicador de Diferença entre os Desempenhos Observado e Esperado (IDD) tem o propósito de trazer às Instituições informações comparativas dos desempenhos de seus estudantes concluintes em relação aos resultados médios obtidos pelos concluintes das demais Instituições que possuem estudantes ingressantes de perfil semelhante ao seu. Para tanto, O IDD, como o próprio nome já diz, é resultante da diferença entre o desempenho médio obtido no Enade pelos estudantes concluintes de um curso e o desempenho médio que era esperado para esses mesmos estudantes, dadas as informações existentes sobre o perfil dos ingressantes desse curso.

Os fatores que determinam o desempenho médio dos estudantes concluintes de uma determinada Unidade $i$ podem ser separados, por hipótese, em três parcelas: a primeira determinada pelas caracteristicas de ingresso destes estudantes concluintes em termos de aprendizagem; outra determinada pela qualidade da formação oferecida pelo curso; e, por fim, um termo de erro que capta os outros elementos que afetam o desempenho do estudante, $e$. Assim, tem-se para uma determinada Unidade $i$ :

$$
c=c^{\prime}+q+e
$$

com a hipótese usual de que $E\left[e \mid c^{l}, q\right]=0$.

As letras minúsculas indicam que as variáveis estão expressas em termos de desvios da média, ou seja, é a 'variável original observada para cada Unidade $i$ menos a 'média da respectiva variável observada para a área de avaliação em nivel nacional $J$ a qual a Unidade pertence'. Assim, $c$ é o desempenho dos estudantes concluintes da Unidade $i$ medido em desvios da nota média de concluintes da área de avaliação em nivel nacional J; $c^{l}$ é o desempenho dos estudantes concluintes da Unidade $i$ no momento de ingresso medido em desvios da media da área de avaliação em nivel nacional $J ; q$ é a qualidade da Unidade $i$ medida em desvios da média da área de avaliação em nivel nacional $J$. 
Não é possivel observar exatamente o desempenho dos concluintes no momento do ingresso $\left(c^{l}\right)$, pois os mesmos, possivelmente, não participaram do Enade quando iniciaram o curso, além deste exame não ser elaborado com metodologia que possibilite comparações entre suas edições devido ao grande volume de áreas avaliadas. Porém, pode-se ter uma estimativa de $c^{\prime}$, por meio do desempenho médio dos ingressantes de cada curso no Enem ${ }^{12}$. A ideia é, para cada Unidade i, utilizar o desempenho dos estudantes ingressantes como uma variável latente ${ }^{13}$ para o desempenho dos estudantes concluintes no momento de ingresso. Assim, o IDD pode ser descrito pela Eq. 14.

$$
\text { idd }=\hat{q}=c-\hat{c}^{I}(14)
$$

Em que $\hat{c}^{\prime}$ é o desempenho previsto dos estudantes concluintes no seu momento de ingresso.

A especificação que subsidia o cálculo do IDD está representada na Eq. 15.

$$
c=\beta i+\gamma \cdot w+\delta \cdot z+\varphi \cdot p d+\lambda \cdot p m+\eta \cdot p r+\rho \cdot f+v \cdot o+u
$$

Como colocado anteriormente, as letras minúsculas indicam que todas as variáveis estão expressas em termos de desvios da média, isto é, subtrai-se da variável original observada para cada Unidade $i$ a média da respectiva variável observada para a área de avaliação em nivel nacional $J$ a qual a Unidade pertence. Na Eq. 15 tem-se:

$c$ : média ponderada das notas dos concluintes no componente específico $(0,75)$ e na formação geral $(0,25)$ da Unidade $i$ no Enade;

$i$ : média das notas dos ingressantes da Unidade $i$ no Enem;

$w$ : proporção de estudantes ingressantes da Unidade $i$ cujo pai e/ou a mãe tem nível superior de escolaridade ${ }^{14}$;

$z$ : razão entre o número de concluintes e o número de ingressantes inscritos na Unidade $i$; $p d$ : proporção de docentes na Unidade i com título mínimo de doutor;

pm : proporção de docentes na Unidade i com título mínimo de mestre;

$p r$ : proporção de docentes na Unidade i com regime de trabalho parcial ou integral;

$f$ : proporção de estudantes da Unidade $i$ que avaliaram positivamente um aspecto da infraestrutura do curso;

0 : proporção de estudantes da Unidade $i$ que avaliaram positivamente um aspecto da organização didático-pedagógica do curso;

$u$ : distúrbio aleatório;

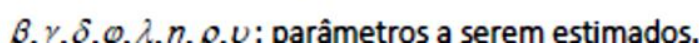

\footnotetext{
${ }^{12}$ Aplicação da utilização do desempenho médio dos ingressantes no Enem é apresentada na Nota Técnica NT/MEC/INEP/DAES n 29/2012.

${ }^{13}$ Proxy (variável indireta).
}

\footnotetext{
${ }^{14}$ As informações sobre a escolaridade dos pais dos estudantes ingressantes são extraídas do questionário socioeconômico respondido pelos estudantes ingressantes no Enem. Considera-se a maior escolaridade entre a do pai e da mãe do ingressante. Para agregar a informação para a Unidade $i$, computa-se a proporção de estudantes da Unidade $i$ cujos pais têm pelo menos ensino superior.
} 
Para a estimativa de $\hat{c}^{\prime}$ - desempenho dos concluintes de uma Unidade $i$ no momento de ingresso - são utilizadas as seguintes variáveis: a nota dos ingressantes da Unidade $i$ no Enem, o nivel de escolaridade dos pais dos estudantes ingressantes e a razão entre o número de concluintes e o de ingressantes inscritos. Esta última variável é incluída como forma de contornar possivel viés de estimação devido à evasão dos estudantes ao longo do curso. Isto porque, para cursos com elevada taxa de evasão, considerando que a evasão seja um fenômeno não aleatório, o perfil médio dos ingressantes pode não representar bem o dos concluintes.

As perguntas utilizadas no Questionário Socioeconômico do Enem sobre a escolaridade dos pais dos ingressantes são as questões dois e três com o seguinte enunciado: Qual é o nivel de escolaridade do seu pai (mãe)? E as respostas possiveis são:

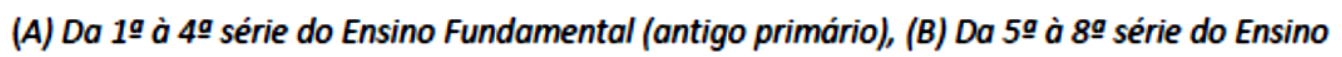
Fundamental (antigo ginásio), (C) Ensino Médio (antigo 2o grau), (D) Ensino Superior, (E) Especialização, (F) Mestrado, (G) Doutorado, (H) Não estudou, e (I) Não sei.

Dessa forma, a proporção de estudantes da Unidade $i$ cujos pais têm pelo menos ensino superior $\left(E S_{i}\right)$ está demonstrada na Eq. 16.

$$
E S_{t}=\frac{n^{\circ} \text { resp } D+n^{\circ} \text { resp } E+n^{\circ} \text { resp } p+n^{\circ} \text { respG }}{\text { total respostas da questão } 2 / 3-n^{\circ} \text { respI }}
$$

As variáveis relativas à qualidade da Unidade $i$ presentes na Eq. (15) especificamente, qualidade do corpo docente e características da infraestrutura e organização didático-pedagógica da Unidade $i^{15}$ - foram inseridas apenas para diminuir 0 viés de estimativa dos coeficientes associados às variáveis características dos ingressantes. Provavelmente, o desempenho dos ingressantes é positivamente correlacionado com a qualidade dos cursos, já que estudantes com boa formação prévia têm maiores chances de ingressar em cursos de melhor qualidade. Assim, parte da qualidade da Unidade i seria captada por estes coeficientes associados às características dos ingressantes, o que faria subestimar o IDD para os cursos que recebem os melhores estudantes. Procurando diminuir este viés, foram incluídas estas variáveis de qualidade do curso. Note que para a estimativa de $\hat{c}^{\prime}$ apenas as características dos ingressantes e a razão concluinte/ingressante são utilizadas.

A Eq. 15 é estimada para cada uma das áreas de avaliação em nivel nacional J. De fato para cada área $J$, a Eq. 15 é estimada duas vezes. Numa primeira, estima-se a

\footnotetext{
${ }^{15}$ Note que estas variáveis são as mesmas descritas anteriormente como componentes individuais do CPC subitens 4.1 a 4.5 .
} 
regressão, computa-se o resíduo e, então, calcula-se o resíduo padronizado, conforme procedimento descrito no item 2.3. (Eq. 1). A partir do resíduo padronizado são identificadas as Unidades com valores extremos, ou seja, as Unidades para as quais o resíduo padronizado foi menor que -3 ou maior que 3 . Na segunda estimativa definitiva, de onde se obtêm os parâmetros $\beta, \gamma e \delta$ para o cálculo de $\hat{c}^{\prime}$ e posterior cálculo do IDD, estas Unidades com valores extremos não são consideradas.

Assim, retomando a Eq. 14, o IDD é calculado conforme apresentado na Eq. 17.

$\hat{c}^{I}=\beta \cdot i+\gamma \cdot w+\delta \cdot z$

$i d d=c-(\beta i+\gamma \cdot w+\delta . z)$

Para o cálculo da média $\left(\overline{I D D}_{J}\right)$ e do desvio padrão $\left(D P_{J}^{M D}\right)$ do IDD, com a finalidade de calcular o afastamento padronizado, são considerados os desempenhos dos concluintes com notas maiores que zero - tanto na parte de formação geral da prova quanto na de conhecimento específico. Além disso, excluem-se das estimações as Unidades com menos de 10 participantes e com taxa de participação inferior a $20 \%$ no Enade e no Enem. $O$ desempenho esperado - IDD, no entanto, é computado para todas as Unidades com 2 ou mais participantes entre ingressantes e concluintes e com taxa de participação mínima de $20 \%$ no Enem.

Obtido o IDD, o passo seguinte, como para demais variáveis, é padronizá-lo e transformá-lo, conforme procedimento descrito no item 2.3., para dar origem à Nota Padronizada do IDD $\left(N I D D_{i}\right)$, um valor entre 0 e 5.

Quando não for possivel atribuir um IDD para uma Unidade i, a Nota Padronizada do IDD $\left(N I D D_{i}\right)$ receberá o mesmo valor da Nota Padronizada de Concluintes $\left(N C_{i}\right)$ para esta Unidade i para o cálculo do CPC. Isso ocorre quando não é possivel estimar os parâmetros de algumas áreas para o cálculo do desempenho esperado dos concluintes pelo fato de não haver nenhuma ou poucas informações, ou quando a Unidade não apresenta os critérios para obter o IDD. 